\title{
Americium/Curium Disposition Life Cycle Planning Study
}

by

W. N. Jackson

Westinghouse Savannah River Company

Savannah River Site

Aiken, South Carolina 29808

J. Krupa

P. Stutts

S. Nester

R. Raimesch

\section{MASTER Y Y}

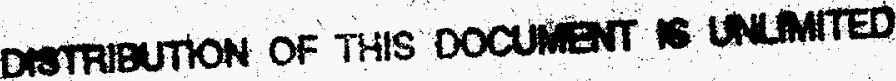

This paper was prepared in connection with work done under the above contract number with the U.S. Department of Energy. By acceptance of this paper, the publisher and/or recipient acknowledges the U.S. Government's right to retain a nonexclusive, royalty-free license in and to any copyright covering this paper, along with the right to reproduce and to authorize others to reproduce all or part of the copyrighted paper. 


\section{UINCLASSIFIED}

\section{AMERICIUM/CURIUM DISPOSITION}

\author{
LIFE CYCLE PLANNING STUDY

(U)

RIDS 397/RSM *10067

Retain until dismantled or disposal ...., review at 10 year intervals.

\section{Prepared by \\ Westinghouse Savannah River Company \\ Savannah River Site Aiken, South Carolina 29808}

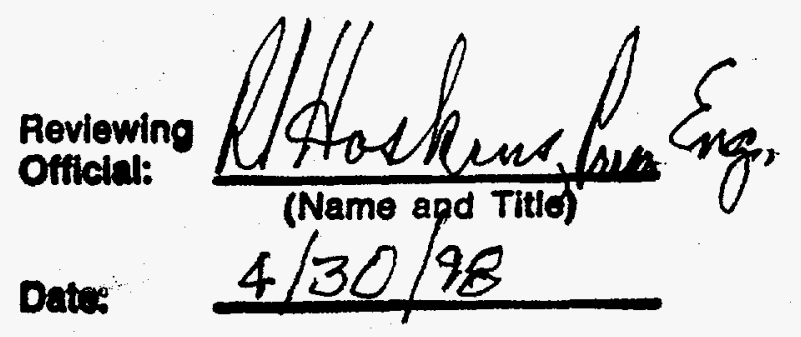




\section{DISCLAIMER}

This report was prepared as an account of work sponsored by an agency of the United States Government. Neither the United States Government nor any agency thereof, nor any of their employees, makes any warranty, express or implied, or assumes any legal liability or responsibility for the accuracy, completeness, or usefulness of any information, apparatus, product, or process disclosed, or represents that its use would not infringe privately owned rights. Reference herein to any specific commercial product, process, or service by trade name, trademark, manufacturer, or otherwise does not necessarily constitute or imply its endorsement, recommendation, or favoring by the United States Government or any agency thereof. The views and opinions of authors expressed herein do not necessarily state or reflect those of the United States Government or any agency thereof.

This report has been reproduced directly from the best available copy.

Available to DOE and DOE contractors from the Office of Scientific and Technical Information, P.O. Box 62, Oak Ridge, TN 37831; prices available from (615) 576-8401.

Available to the public from the National Technical Information Service, U.S. Department of Commerce; 5285 Port Royal Road, Springfield, VA 22161. 


\section{DISCLAIMER}

Portions of this document may be illegible in electronic image products. Images are produced from the best available original document. 
APPROVAL SIGNATURES OF CORE TEAM<smiles>C1CC1C1CC1C1CC1</smiles>

W.N. Jackson, Manager

WSRC Systems Engineering Applications -

NMSS \& New Missions (EA1BO)

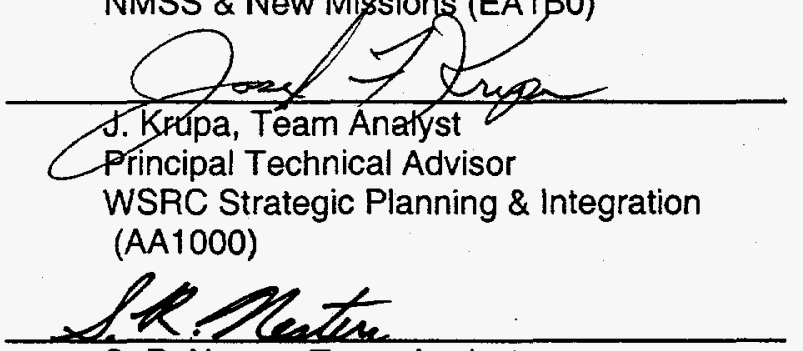

S. R. Nester, Team Analyst

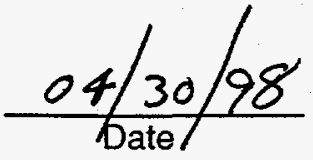

Senior Engineer

WSRC Systems Engineering Application -

NMSS \& New Missons (EA1B9)

faben fain'se h

R. Rainisch, Team Analyst

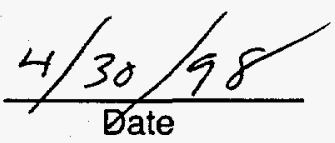

Principal Engineer

WSRC Systems Engineering Application -

NMSS \& New Missions (EA1B9)

$?$

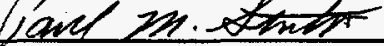

P. M. Stutts, Team Analyst

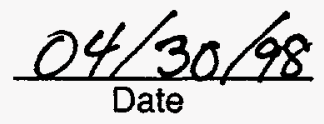

Principal Engineer

WSRC Systems Engineering Application -

NMSS \& New Missions (EA1B9)
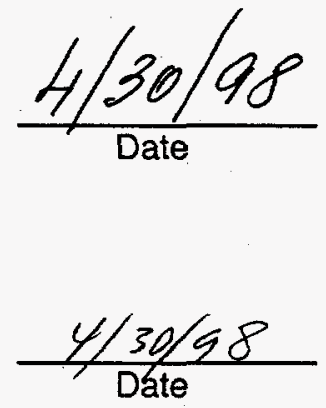


\subsection{EXECUTIVE SUMMARY}

At the request of the Department of Energy Savannah River Office (DOE-SR), Westinghouse Savannah River Company (WSRC) evaluated concepts to complete disposition of Americium and Curium (Am/Cm) bearing materials currently located at the Savannah River Site (SRS). Am/Cm.bearing materials at SRS are basically in three groupings: Tank 17.1 solution, Mark 18 target assemblies (Mk18s), and a class of materials referred to as "Slugs/Other".

Removal of all Am/Cm from SRS in Fiscal Year (FY) 2005 is technically possible, with the proper priorities and funding. Removal in FY2007 is more probable, when noting normal time frames for programs of this magnitude.

This study concludes the following:

- All disposition paths evaluated are technically feasible (cutting of Mk18s in RBOF is feasible, but strongly not recommended).

- All disposition paths evaluated have manageable Environmental, Safety \& Health (ES\&H) and Programmatic Risks (cutting of Mk18s being the least desirable).

- All SRS Am/Cm bearing materials could be removed from SRS prior to the end of FY2005, but some will likely remain until at least FY2007 (primary limiting factors: obtaining programmatic decisions pertaining to funding and priority, i.e. not technical issues).

- If F-Canyon PUREX process Decontamination and Decommissioning (D\&D) is initiated, Am/Cm disposition will probably not be a limiting factor (required $F$ Canyon functions could still be available).

This study recommends the following:

- Immediately begin project activities to install a welder in MPPF for packaging glass canisters.

- Continue pre-conceptual activities this FY to support recommended projects.

- Ship the Am/Cm glass product (from Tank 17.1 "Solution") to ORNL from F Canyon, i.e., not using the SRS Receiving Basin tor Off-site Fuels (RBOF)

- Consider interim storage at SRS of the glass product from Tank 17.1 "Solution".

- Process Mk18s to glass, i.e., from RBOF storage to F-Canyon for processing and stabilization as glass, then to ORNL..

- Review utilization of $F$ Canyon existing equipment as alternative to installation of a new dissolver.

- Package the Slugs/Other Am/Cm bearing materials at $\mathrm{RBOF}$ for direct shipment to ORNL.

Assuming the currently active project/program $[-\$ 80 \mathrm{M}$ total cost (shows in "Current Program" below), $~ \$ 30 \mathrm{M}$ spent to date] to vitrify Tank 17.1 "Solution" is successful (vitrification complete in FY2002), the following additional funding would be required to complete the disposition of the vitrified material and the other two material types:

\begin{tabular}{|c|c|c|c|c|c|}
\hline- & $\begin{array}{l}\text { Make Glass } \\
\text { (Stabilize) }\end{array}$ & $\begin{array}{c}\text { Par:kage for } \\
\text { Shipmient/Storage }\end{array}$ & $\begin{array}{l}\text { Transport to } \\
\text { ORNL }\end{array}$ & $\begin{array}{c}\text { Storage @ } \\
\text { ORNL }\end{array}$ & TOTAL \\
\hline $\begin{array}{l}\text { Tank 17.1 } \\
\text { Solution }\end{array}$ & $\begin{array}{c}\text { Current } \\
\text { Project/Program }\end{array}$ & $\$ 0.7-2.6 \mathrm{M}$ & $\$ 2.2-8.9 \mathrm{M}$ & $\$ 3.5-14 \mathrm{M}$ & $\$ 6.4-25.5 \mathrm{M}$ \\
\hline Mark 18S & $\$ 4-14 \mathrm{M}$ & -NA- & $\$ 0.2-0.8 \mathrm{M}$ & -NA- & $\$ 4.2-14.8 \mathrm{M}$ \\
\hline Slugs/Other & -NA- & $\$ C .4-1.6 \mathrm{M}$ & $\$ 0.1-0.4 \mathrm{M}$ & -NA- & $\$ 0.5 .2 \mathrm{M}$ \\
\hline TOTAL & $\$ 4-14 M$ & $\$ 1,1-4.2 \mathrm{M}$ & $\$ 2.5-11.1 \mathrm{M}$ & $\$ 3.5-14 \mathrm{M}$ & 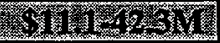 \\
\hline
\end{tabular}

These are planning level costs over the entire life cycle to place all SRS Am/Cm materials into storage at ORNL and cover incremental costs above current $F$ canyon and ORNL operating/maintenance costs. This scope and funding are not in the 1998 Annual Operating 
WESTINGHOUSE SAVANNAH RIVER COMPANY

Americium/Curium Disposition Life Cycle Planning Study(U)
Document: NMP.PLS-980044

Revision 0

April 30, 1998

Page 5 of 159

Plan (AOP) or out year projections. If added, the skilled manpower required would be in competition with current projected projects, which would require a review of priorities. Upon completion of pre-conceptual activities, the planning level scope, costs, schedules and risks within this report would be refined. 


\subsection{TABLE OF CONTENTS}

1. O EXECUTIVE SUMMARY

\section{0 DISCUSSION}

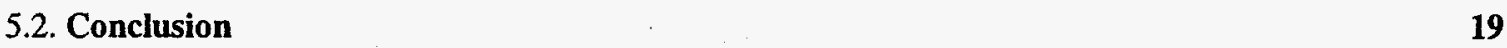

5.3. Recommendations 19

5.4. Path Forward Recommendations

6.1. Problem Statement $\quad 23$

6.1.1. Strategy 23

6.1.2. Initial State $\quad 24$

6.1.3. Final State $\quad 24$

6.1.4. Goals/Objectives - $\quad 24$

6.2. Functions

6.3. Requirements 25

$\begin{array}{ll}\text { 6.4. Interfaces } & 25\end{array}$

6.5. Assumptions 25 
6.7.1. Tank 17.1 "Solution" Disposition - Base Alternative (double containment, MPPF-RBOF-ORNL)27

6.7.2. Tank 17.1 "Solution" Disposition - Alternative \#1 (double containment, RBOF-ORNL) 28

6.7.3. Tank 17.1 "Solution" Disposition - Alternative \#2 (double containment, MPPF-ORNL) 29

6.7.4. Tank 17.1 "Solution" Disposition - Alternative \#3 (single containment, MPPF-ORNL) 30

6.7.5. Tank 17.1 "Solution" Disposition - Alternative \#4 (double containment, SRS Interim storage-ORNL)

6.7.6. Tank 17.1 "Solution" Disposition - Alternative \#5 (double containment, SRS interim storage-

National Repository)

6.7.7. "Mark 18" Disposition - Base Alternative (double containment, RBOF-ORNL)

6.7.8. "Mark 18" Disposition - Alternative \#1 (make glass, single containment, MPPF-ORNL)

6.7.9. "Slugs/Other" Disposition - Base Alternative (double containment, RBOF-ORNL)

6.7.10. Potential Alternatives not Evaluated

\section{0 REFERENCES}

9. 0 APPENDICES

9.1. Appendix A: “Americium/Curium (Am/Cm) Disposition Study" Anderson 39

9.2. Appendix B: : “Americium/Curium (Am/Cm) Disposition Study (U)" Jordan 40

9.3. Appendix C: Core Team for developing the Am/Cm Disposition Life-Cycle Planning Study 41

9.4. Appendix D: Team Domain Experts for Am/Cm Disposition Life-Cycle Planning Study 46

9.5. Appendix E: Reviewers for Am/Cm Disposition Life-Cycle Planning Study 49

9.6. Appendix F: Am-Cm Vitrification Development Program Plan Overview 50

9.7. Appendix G -- Off-Site Transportation -- Packaging Considerations 51

9.8. Appendix H: Representative Figures.

9.8.1. Legend $\quad 53$

$\begin{array}{ll}\text { 9.8.2. Packaging Figures } & 54\end{array}$

\begin{tabular}{l} 
9.8.3. Mark 18 Packaging Figures \\
\hline 9.8 .4 Tank
\end{tabular}

9.8.4. Tank 17.1 Disposition Functional Flow Paths $\quad 56$

\begin{tabular}{l} 
9.8.5. Mark 18 Disposition Functional Flow Paths \\
\hline 97
\end{tabular}

9.8.6. Slugs/Other Disposition Functional Flow Paths $\quad 58$

9.9. Appendix I - Expanded Base Cases and Alternatives

9.9.1. Tank 17.1 "Solution" Disposition - Base Case 59

9.9.2. Tank 17.1 "Solution" Disposition - Alternative One $\quad 69$

9.9.3. Tank 17.1 "Solution" Disposition - Alternative Two

9.9.4. Tank 17.1 "Solution" Disposition - Alternative Three $\quad 79$

9.9.5. Tank 17.1 "Solution" Disposition - Alternative Four - Interim Dry Cask Storage 83

9.9.6. Tank 17-1 "Solution" Disposition - Alternative Five: Treat Glass as Waste 88 
9.9.7. "Mark 18s" Disposition - Base Alternative

9.9.8. "Mark 18s" Disposition - Alternative One: Review 96

9.9.9. "Slugs/Other" Disposition - Base Alternative 102

9.10. Appendix J: “National Asset” Recommeniation 104

9.10.1. Am/Cm Solution National Asset Recommendation, Chuck Alexander, ORNL 104

9.10.2. Am/Cm Solution Value, Seaborg $1994 \quad 105$

9.10.3. Am/Cm Solution Value, Seaborg $1992 \quad 105$

9.10.4. Am/Cm Solution Potential Uses, Seaborg 1992

9.11. Appendix K: Cost Analysis $\quad 106$

9.11.1. Tank 17.1 "Solution" Disposition - Base: Alternative $\quad$. 106

9.11.2. Tank 17.1 "Solution" Disposition - Altennative One 107

9.11.3. Tank 17.1 "Solution" Disposition - Alternative Two 107

9.11.4. Tank 17.1 "Solution" Disposition - Altemative Three 108

9.11.5. Tank 17.1 "Solution” Disposition - Altemative Four 109

9.11.6. Tank 17.1 "Solution" Disposition - Altemative Five 110

9.11.7. "Mark 18s" Disposition - Base Case 11

9.11.8. "Mark 18s" Disposition - Alternative One 111

9.11.9. "Slugs/Other" Disposition - Base Case 112

9.12. Appendix L: Disposition Path Evaluation; $\quad 113$

9.12.1. Disposition Path Maturity Evaluations $r 113$

9.12.2. Programmatic Risk Assessments $\quad 126$

9.12.3. Am/Cm ES\&H Risk Assessments $\quad 128$

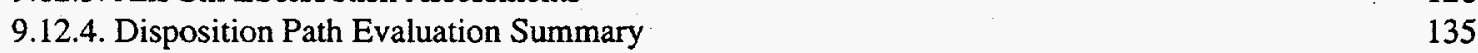

9.13. Appendix M - Disposition Path Maturity Evaluation Score Basis 138

9.13.1. Tank 17.1 "Solution"- Base Alternativ": 138

9.13.2. Tank 17.1 "Solution" - Alternative \#1 143

9.13.3. Tank 17.1 "Solution" - Alternative \#2 145

9.13.4. Tank 17.1 "Solution" - Alternative \#3 . 147

9.13.5. Tank 17.1 "Solution" - Alternative \#4. 147

9.13.6. Tank 17.1 "Solution" - Alternative \#5: 149

9.13.7. "Mark 18s" - Base Alternative $\quad 152$

9.13.8. "Mark 18s" - Alternative \#1 154

$\begin{array}{lr}\text { 9.13.9. Slugs/Other - Base Alternative } & 156\end{array}$

9.14. Appendix N: Mark 18s Background 157 


\subsection{INTRODUCTION}

This study defines the disposition paths recommended for special isotope materials containing significant quantities of $\mathrm{Am} / \mathrm{Cm}$ currently located at SRS. The materials are in three categories, Am/Cm solution located in F Canyon Tank 17.1, Mark 18 targets (Mk 18s) located in RBOF and a material category referred to as "Slugs/Other" located in RBOF. The recommendations for the Tank 17.1 solution pertain to functions/tasks required after the material is vitrified in F-Canyon's MultiPurpose Processing Facility (MPPF), a currently active project/program ${ }^{(1)}$. The paths are planning level life-cycle, i.e., they include scopes, costs, schedules and risks to take the Am/Cm material from it's current to final state and are pre-conceptual ${ }^{(2,3)}$ in nature.

This study also provides recommendations on follow up actions to move the disposition programs forward.

\subsection{Background}

This study was prepared as a response to a DOE-SR request (Appendix A), with direction provided by WSRC-NMSS (Appendix B), for recommendations to complete disposition of vitrified Tank 17.1 $\mathrm{Am} / \mathrm{Cm}$ Solution (vitrification via F-Canyon's Multi-Purpose Processing Facility (MPPF)). A primary concern of the study was to resolve the potential impact on current planning schedules for PUREX process D\&D, and other D\&D activities if the Tank 17.1 solution, stabilized as glass, remained in $F$ Canyon for an extended period of time. Disposition alternatives were to include life cycle functions, include planning level scope, costs, schedules and risks.

The Tank 17.1 vitrified material is being considered for shipment to Oak Ridge National Laboratory (ORNL), as are Am/Cm bearing targets (Mark 18s) and Slugs. Therefore, the scope of the study was expanded to include all SRS Am/Cm bearing materials to insure impacts on ORNL could be properly evaluated, with the benefit of having complete SRS Am/Cm disposition paths. ORNL intends to utilize the $\mathrm{Am} / \mathrm{Cm}$ bearing materials in their special isotope production programs.

The study was to be completed before the end of April, primarily to enable planning for FY99 and out-year programs and enable timely input to the SRS Spent Nuclear Fuel Management EIS ${ }^{(4)}$. This timing also meets an objective of the DOE complex wide Nuclear Materials Integration Project ${ }^{(\dot{)})}$ (NMI), to complete a pilot trade study that meets overall NMI Project objectives.

\subsection{Approach}

A core team was established to develop this study, and was provided independence of site wide organization influence to draw conclusions and make final recommendations. A team of "Domain" experts (see Appendix D) was established to provide the required process detail knowledge and to assist with development of corresponding costs, schedules and risks. A list of reviewers (Appendix E) was also established to supplement domain experts' reviews.

This study was to be performed using the Systems Engineering (SE) approach ${ }^{(6)}$, covering the entire life cycle of the material. The specific approach selected to evaluate alternatives and assist with decision making was defined within the NMI Project (under development as this study progressed). Using the NMI evaluation approach served several purposes: • assisted development of the NMI evaluation approach, • provided a trade study needed by NMI, • provided another level of independence by using an evaluation process being developed for DOE complex wide utilization, i.e., not SRS site or Division specific.

The following represents the basic process steps followed by the core team: 
- Review site specific plans and DOE 2006 plans to establish base disposition paths

- Establish goals/objectives and requirements based on the DOE SR request and NMI Project

- Survey domain experts (sometimes referred to as subject matter experts) to establish baseline path alternatives

- Screen alternatives (section 6.7.10) to eliminate low potentials before proceeding with further analysis

- Evaluate alternatives for dispositioning:

- Glass from Tank 17.1 Solution (Six paths were evaluated)

- Mark 18s (Two paths were evaluated)

- Slugs/Other (The baseline path was evaluated)

- Review NMI Disposition Path Maturity (D/PM) process and "score" paths with domain experts

- Further develop scope, costs, schedules and risks based on previous meeting

- Highlight potential sensitivities of the overall approach and review for impacts

- Complete Assessment and Evaluation prijess to draw conclusions and recommendations (section 4.1)

- Release working draft to domain experts and reviewers for comments

- Review and resolve comments

- Incorporate comments and reissue study "final draft" for comments to a slightly larger audience

- Incorporate final comments as appropriate and issue study Revision 0

\subsection{DISCUSSION}

The following section overviews goals/objectives of this study, basic process used, several drivers for performing the study and the disposition paths evaluated.

The goals/objectives (section 6.1.4 for details) of this study were based on the NMI Project goals and the requesting DOE-SR letter (Appendix $A$, with constraints outlined in the WSRC response (Appendix B)). Four areas summarize these goals/objectives:

- Reduce risks

- Minimize costs

- Reduce schedules

- Recommend full life cycle disposition paths

Applying the systems engineering process assisted with identification of issues and focus of the domain experts during reviews. The actual scoring process (being developed for use in the NMI Project) assisted also, but did not provide clear discriminators of the alternatives evaluated in this study.

The 94-1 program $^{(7)}$ drove the need to stabilize the Tank 17.1 solution, which resulted in the current on going project/program to vitrify the solution to glass. The 94-1 program did not drive the completion of the Tank 17.1 solution disposition path, i.e. the material would be stabilized in glass but left in $\mathrm{F}$ Canyon. The four goals/objectives listed above plus the requirements (section 6.3) were considered when making the conclusioris and recommendations based on this study.

The "Mark 18s" and "Slugs/Other" are currently located in RBOF and will require removal prior to closure of RBOF. Planning efforts for RBOF closure and the goals/objectives listed above, were also considered when making the conclusions and recommendations.

The following lists disposition paths evaluated for: Tank 17.1 Solution

- Base Alternative: double containment using MPPF \& RBOF with shipment to ORNL

- Alternative \#1: double containment using RBOF with shipment to ORNL

- Alternative \#2: double containment using MPPF with shipment to ORNL 
- Alternative \#3: single containment using MPPF with shipment to ORNL

- Alternative \#4: double containment using MPPF, with SRS interim storage and periodic shipment to ORNL

- Alternative \#5: double containment using MPPF, with SRS interim storage and eventual shipment to a National Repository

Mark 18s

- Base Alternative: double containment using RBOF with shipment to ORNL

- Alternative \#1: disolve in F Canyon, make glass using MPPF, provide single containment via shipping cask loaded in F Canyon railroad tunnel, shipment to ORNL

Slugs/Other

- Base Alternative: double containment using RBOF, shipments to ORNL

Several additional alternatives were identified but screened out from further analysis (see 6.7.10).

\subsection{Assessment and Evaluation process}

The following is the process utilized to asses and evaluate the disposition paths. The process is based on the NMI process, with additional guidance in the areas of disposition path comparison and recommendations.

1. Establish Goals/Objectives (see section 6.1 of this report)

2. Establish Requirements (see section 6.3 of this report)

3. Perform Disposition Path Maturity (DPM), Programmatic Risk (PR), and ES\&H (ES\&Hv) Vulnerability assessments.)(Appwendix $L$ )

4. Perform cost assessments (CA) for each disposition path being evaluated.

5. Tabulate results from DPM, PR, ES\&Hv, \& CA.

6. Synthesize DPM, PR, ES\&Hv, and CA into a single score.

7. Compare top synthesized scores with Goals/Objectives and Requirements

8. Recommend a disposition path

9. Highlight upper level actions/decisions needed to assist with moving recommendations forward.

The current NMI assessment and evaluation process consists of the following steps:

1. Perform Disposition Path Maturity (DPM), Programmatic Risk (PR), and ES\&H Vulnerability (ES\&Hv) assessments.

2. Perform cost assessments (CA) for each disposition path being evaluated

3. Tabulate results from DPM, PR, ES\&Hv, \& CA

4. Compare and evaluate tabulated information

5. Recommend a disposition path for each material type/category

Within the NMI process, DPM, PR and ES\&Hv have well defined criteria enabling evaluations across alternatives to be fairly consistent (see Appendix $L$ for criteria). The cost assessment (CA) process is not as prescriptive and leaves a fairly wide latitude for what should be included. Uniform CA across multiple alternatives is accomplished by the core teams' careful comparison of each alternatives specific functions and costs. No specific guidance is provided in the NMI process for performing the final two steps, i.e. the comparison and recommendation steps.

\subsection{Discussion of Disposition Paths}

This section presents discussions on the disposition paths for each of the three material types, with focus on the recommended disposition path. Overviews of all disposition paths are in section 6.7, with additional details in Appendix I. 


\subsubsection{Tank 17.1 "Solution" Disposition}

The Tank 17.1 "Solution" Disposition path recommended is Alternative \#3 (see Section 6.7.4), (see flow chart below).

Alternative Three disposition begins with Am/ $\mathrm{Cm}$ solution stored in F-Canyon Tank 17.1. The solution is pretreated with oxalic acid to rernove transition metals, such as $\mathrm{Cr}, \mathrm{Ni}$, and $\mathrm{Fe}$ and transferred to a feed tank in the MPPF for vitrification. Vitrification is a batch feed process at the end of which the molten glass drains from the meiter into a "canister" (Appendix $\mathrm{H}$, section 9.8.2, Figure 1). The canister is sealed but does not provide a containment boundary. The canisters are lag stored in the MPPF.

The canisters will be retrieved from lag storage in MPPF, seal welded in a contamination control canister (CWP-2) (Appendix H, section 9.8.2, Figure 2.2)) using a welder installed in an MPPF cell. The CwP-2 will be decontaminated and placed in a off-site shipping cask. The shipping cask will be decontaminated and then shipped to ORNL form F Canyon. ORNL will remove the CwP-2s from the shipping cask assembly and store the $A \mathrm{~m} / \mathrm{Cm}$ glass in situ in the CWP-2s. When needed, ORNL will remove a CWP from storage for processing the glass into products.

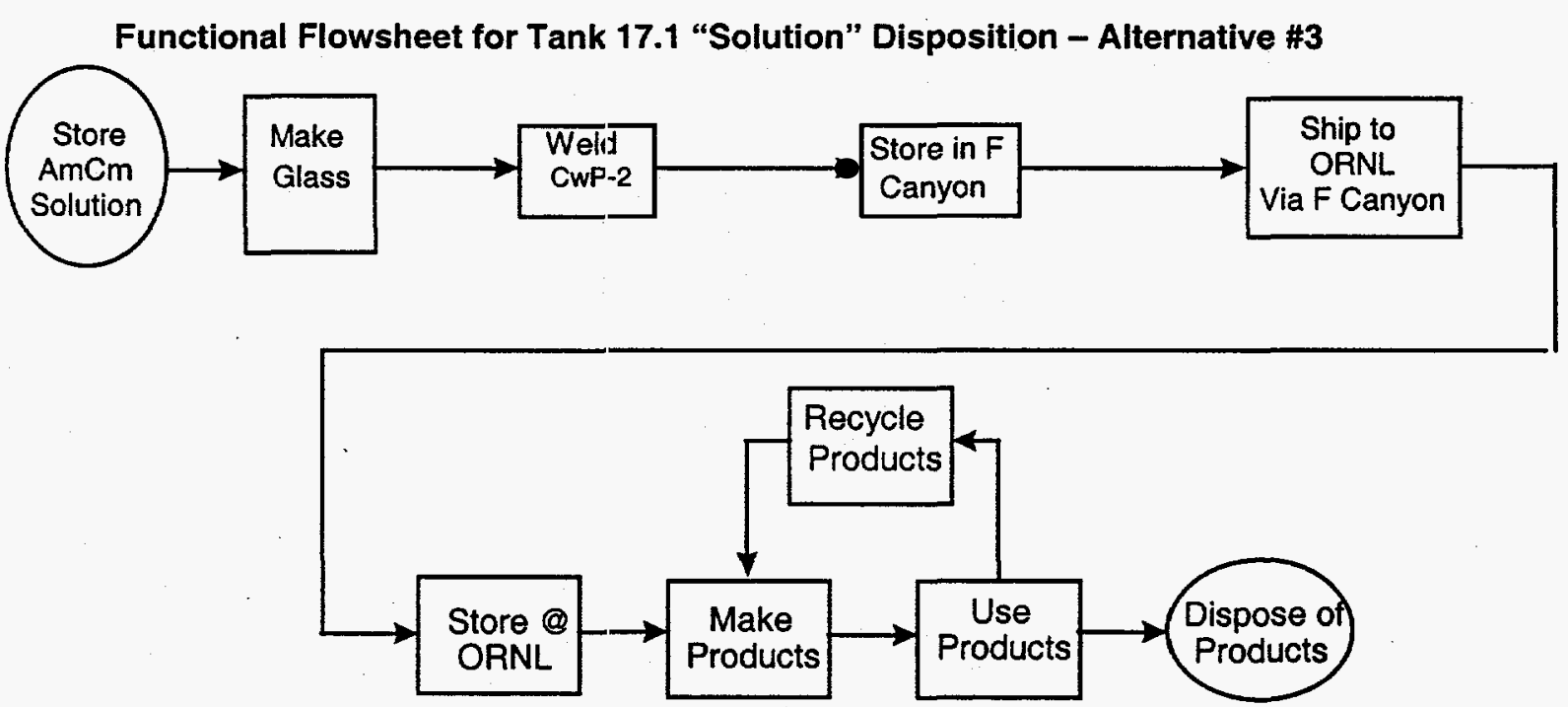

The initial functions of "Store Am/ Cm Solution" and "Make Glass" were not evaluated, they were assumed to be successful. The solution has been stored safely for many years and the current project/program to vitrify the solution is currently making significant progress. Assumptions , interfaces, etc. are defined in Appendix I. An overview of the current program is in Appendix F. Interfaces with the "Make Glass" function were considered.

The ORNL functions from "Store @ ORNL" downstream were not evaluated either. The current program at ORNL for making special isotopes will remain into the foreseeable future, therefore all functions with their associated costs, schedules and risks were assumed to be covered by the on going special isotope programs. But, interfaces with the function "Store at ORNL" and any scope required beyond the current special isotope program was considered, i.e. providing additional storage required for some disposition options and any NEPA activities. 
Alternative \#3 minimizes the handling of the vitrified solution, with resultant reductions of risks, cost, and schedules compared to the other alternatives. The following "technical" scope would require completion:

- Installation of a welder in a MPPF cell

- Approval to make shipments utilizing an existing single containment cask

- Testing to insure contamination limits pertaining to shipments and storage at ORNL may be met

- Installation of additional storage capacity at ORNL

- NEPA evaluations for the extended storage capacity (and time frame) at ORNL

These scope items were considered to be not technically challenging, but schedules could become an issue when considering programmatic decisions on funding and priorities to obtain the required manpower and facilities. The largest cost and highest programmatic risk is with the ORNL functions. Therefore as a backup, interim storage at SRS was evaluated. If the "Transfer and Storage Facility" being considered for installation in L-area is completed, adding the small amount of additional dry storage required for the vitrified tank 17.1 solution would require less funding then the ORNL storage and probably would be simpler from a programmatic view.

The following is a discussion of the technical scope listed above that would require completion.

\section{Installation of Welder}

SRTC designed, built, and tested a welder for installation within MPPF for use in sealing the glass canisters. This design could be easily modified for the "contamination control canister" (CWP-2) which has a slightly larger diameter than the glass canisters. This could be a small project handled by the NMSS organization (a Division Managed Modification (DMM)).

In addition, a remote welder capable of providing full penetration welds for use with the MK-42s was installed at Hanford and was successfully used. The design of this equipment, operating procedures, and several individuals involved with the program are still available.

As a backup, welding could be performed in RBOF, but would have to be underwater (adds different complexity compared to welding within MPPF (assuming the same level of contamination control)) and would add complexity to RBOF operations (increases packaging equipment and personnel, and increases shipments to and from RBOF compared to current plans) resulting in additional scope requiring completion prior to RBOF closure.

\section{Approval to make single containment shipments}

The plutonium content may be low enough to enable single containment shipments. But, to insure the Pu content does not become a limiting constraint on the quantity of material to be shipped; a "waiver" would be pursued (since the material will be in a glass form). If the "waiver" could not be obtained, double containment could be provided by qualifying the contamination control canister as a "shipping containment vessel" and qualifying the shipping package for double containment (See Section 6.7.3). The SRTC-Packaging Organization is currently investigating various shipping options.

Shipment from F-Canyon to off-site is not a typical canyon function, but is within the facility/operation capabilities. The basic concern is the capability to decontaminate containers leaving MPPF for placement into an off-site shipping cask, and decontamination of the off-site shipping cask. Experience being gained currently through decontamination of MPPF racks may provide enough information to resolve this concern. If not, a simple testing program could resolve the current capabilities and determine where improvements would be beneficial.

As a backup, if the container welded in MPPF could not be decontaminated to acceptable shipping levels (still must meet ORNL acceptable levels) a mechanically sealed qualified shipping container 
( $\mathrm{msQSC}$ ) could be added. (Section 6.7 .3 with a additional function of sealing a msQSC prior to leaving F-Canyon).

Installation of additional storage capacity at ORNL

The basic storage design is well known and facilities exist with adequate space to permit installation. But, since the quantity of material is much larger than ever envisioned for the facilities, NEPA evaluations are assumed to be required.

If schedule delays result in ORNL obtaining the required storage space long after it is needed, several SRS options may be pursued:

- Leave material within MPPF (the functions required to move the material will be available even after (BPUREX processing capability is eliminated).

- Store in new dry interim storage at SRS (See Section 6.7.4). If the "Transfer Storage Facility" (TSF) is built for handling spent fuel at SRS, then a few additional dry storage modules could be added. If the TSF is not built and the funds to build a limited TSF for interfacing with the dry storage are not allocated, storage at DINPF (in storage areas already built but not to be used (due to "diameter" issues), could be investigated.

- Disposition Tank 17.1 solution to waste via the National Repository (See Section 6.7.5). The designation of the material as "programinatic" would have to be changed before this option is pursued. Once the material is designated as waste, a program to qualify the waste form would be required, and interim storage at SR'S would still be required. In addition, ramifications of designating the material as waste vrould require full investigation, i.e. waste storage requirements are different from material in use or programmatic material.

\subsection{2. "Mark 18s" Disposition}

Of the two paths evaluated, the "Mark 18s" Disposition path Alternative \#1 (see 6.7.8) is recommended (see flow chart below).

Alternative One begins with the Mk 18 s stored in RBOF. All Mk 18 s are transported to F-Canyon for processing via the onsite transfer cask. Processing involves dissolving the Mk 18s, pretreating the Mk 18 slurry as necessary, storing the slurry in a feed tank, then vitrification via MPPF. The vitrification frit will be adjusted to enable this solution to be vitrified. Vitrification is a batch feed process at the end of which the molten glass drains from the melter into a "canister" (Appendix $\mathrm{H}$, section 9.8.2 Figure 1). The canister is then welded closed. After being loaded into a CWP-1 or 2 (Appendix $\mathrm{H}$, section 9.8.2, Figure 2.1 or 2.2.), the CwP-1 (or 2) is lag stored in MPPF. The glass path from solution to ORNL would be one of the alternative cases shown in Sections 6.7.1, 6.7.2, 6.7 .3 , or 6.7.4. When needed ORNL will remove a CwP form storage and process the glass to products. 


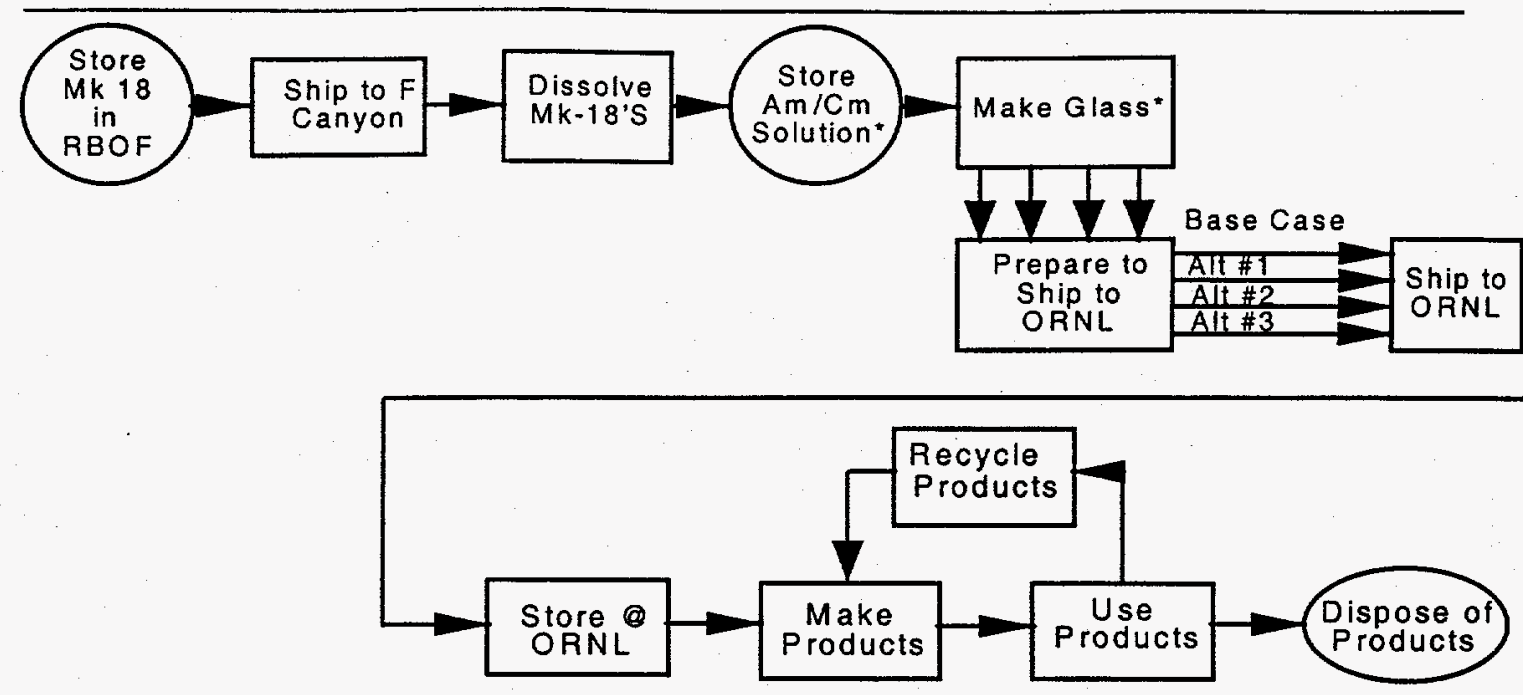

The initial function "Store Mk 18 in RBOF" was not evaluated since this is a currently performed function with no major issues. Functions downstream of and including "Make Glass" were not evaluated, since they were identified and evaluated for disposition of Tank 17.1 solution. Interfaces between and with these functions were considered. The primary differences between the Mark 18s and Tank 17.1 are:

- Mark 18 s require dissolution to produce the solution feed stream to making glass

- Glass should be shipped to ORNL, even if the glass from tank 17.1 solution feed is interim stored on site. ORNL has storage capacity and capability for glass produced from the Mark $18 \mathrm{~s}$ (and for all the "slugs/other" materials) but does not have the capacity for all the Tank 17.1 glass.

The Mark 18s Alternative \#1 minimizes the ES\&H risks associated with cutting into the Mark 18 core (Mark 18s Base Alternative) with resultant reductions of risks, cost, and schedules. No one contacted felt this was an option that should be pursued. Some individuals recalled an earlier attempt at cutting a similar material in RBOF that resulted in a large hut to enable decontamination. Assuming the contamination control was to be the same for both alternatives, the equipment for cutting and packaging under water in RBOF would likely be more complicated and less proven then utilizing a dissolver installed in $\mathrm{F}$ canyon. Note: Utilization of existing dissolvers and equipment within $F$ Canyon should be evaluated if the decision to process at SRS is made. This would probably decrease costs, schedule and risk.

The following "technical" scope would require completion:

- Evaluation of Tank 17.1 solution vitrification equipment life expectancy (to insure required equipment is available for the Mark 18s)

- Evaluation of solution produced to enable adjustments in vitrification process (considered minor R\&D)

- Installation of an existing dissolver in F Canyon (Used to cost/schedule this alternative, but a backup to be considered would be utilization of existing $F$ Canyon facilities/equipment and staff, by which a substantial reduction in cost and schedule is possible.

- Approval to make shipments utilizing an existing single containment cask (same scope as in the Tank 17.1 disposition selected alternative)

- Testing to insure contamination limits pertaining to shipments and storage at ORNL may be met (same scope as in the Tank 17.1 disposition selected alternative) 
WESTINGHOUSE SAVANNAH RIVER COMPANY

Americiüm/Curium Disposition Life Cycle Plannin! Study(U)
Document: NMP-PLS-980044

Revision 0

April 30, 1998

Page 16 of 159

As was the case with the Tank 17.1 Soluticin Disposition Alternative \#3, these scope items were considered uncomplicated and very technically feasible, but schedules could become an issue when considering programmatic decisions on funding and priorities to obtain the required manpower and facilities.

The following is a discussion of the technical scope listed above that would require completion.

Evaluation of Tank 17.1 solution vitrification equipment life expectancy

The current project/program for Tank 17.1 solution vitrification ensures equipment life is adequate (or spares are identified) to enable vitrification of the entire Tank 17.1 solution. An evaluation would be required, before final design of the existing project, to insure equipment life would be adequate for the extra material created from dissolving the Mark 18s and or to allow needed spares to be identified.

Evaluation of solution produced to enable adjustments in vitrification process

The solution makeup from dissolving the Mark $18 \mathrm{~s}$ would need to be compared to the Tank 17.1 solution to determine the proper feed stream adjustments and possible frit adjustments. This would be accomplished by a short R\&D program beginning after the current vitrification R\&D is complete, and would provide the initial requirements for the process flow sheet and equipment needs for the Mark 18s.

Installation of an existing dissolver in $\mathrm{F}$ Canyon

The dissolver and associated equipment was to be installed previously, but the need to disposition the Mark 18s did not justify the expense anid manpower. The previous project would need to be rescoped and estimated with current requirements, but no major technical issues were foreseen.

Note: Utilization of existing $\mathrm{F}$ Canyon facilities, equipment and staff should be fully investigated. Previous studies and tests indicate a nitric acid flow sheet would enable utilization of existing process equipment. Priority issues for limited skilled manpower would require resolution to fully develop this alternative.

Approval to make shipments utilizing an existing single containment cask \& Testing to insure contamination limits pertaining to shipments and storage at ORNL may be met

(Same scope as in the Tank 17.1 disposition selected alternative)

\subsection{3. "Slugs/Other" Disposition}

The "Slugs/Other" Disposition path recommended is the Base Alternative (see 6.7.9) (flow sheet shown below).

The base case begins with Slugs/Other stored in RBOF and finishes at ORNL. The Slugs/Other are loaded into a CWP-3 (Appendix $H$, section 9.8.2, Figure 2.3), provided with an internal helium atmosphere, mechanically sealed into an msQSC, (Appendix $H$, section 9.8.2, Figure 4), and lag stored pending shipment to ORNL. The MSCSC will be retrieved and shipped to ORNL, where the CWP-3 will be removed for in situ storage and use. Existing msQSC equipment is utilized to load the package into the off-site shipping cask. When needed, ORNL will remove a CWP from storage and process the slugs/other material into user products. 


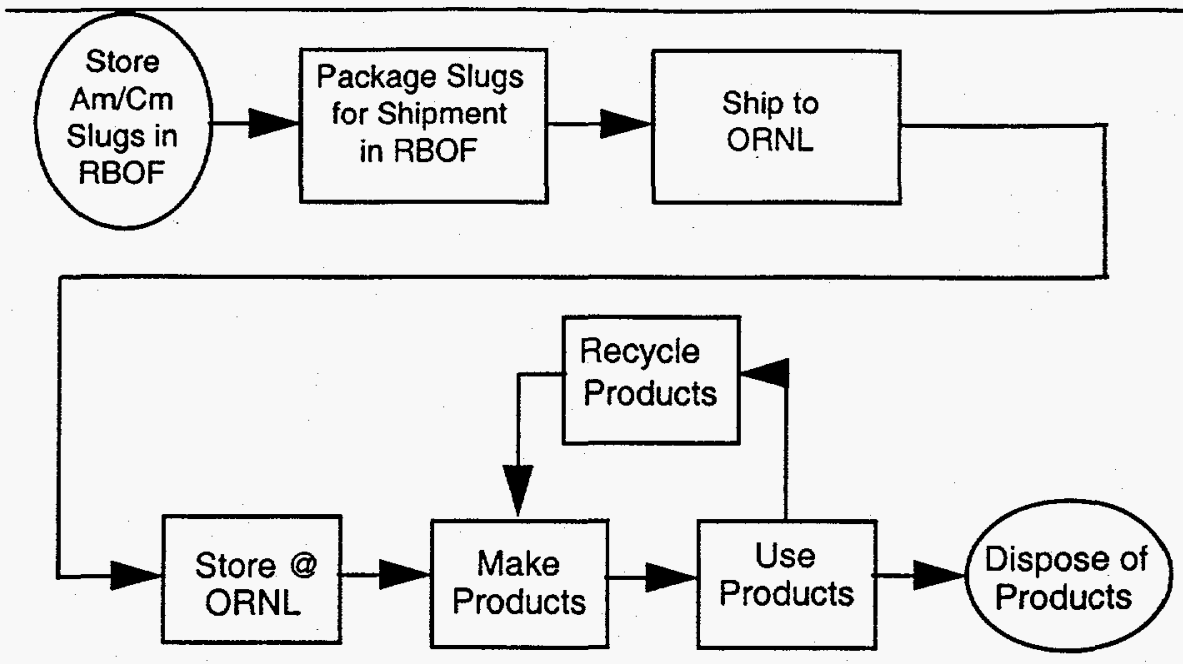

The initial function "Store Am/Cm Slugs/Other in RBOF" was not evaluated since this is a currently performed function with no major issues. Functions downstream of and including "Store at ORNL" were not evaluated, but interfaces between and with these functions were considered.

No alternatives were identified since the current planning and existing processes met all objectives/goals and requirements. Currently the "Slugs/Other" material is being planned for shipment to ORNL during FY1999.

\subsection{CONCLUSION \& RECOMMENDATIONS}

This section provides an overview of the recommended disposition paths, with conclusions, recommendations and suggested path forward.

\subsection{Overview}

The following upper level questions and corresponding answers were developed after reviewing all the data, completing the analysis and documenting the study. These are fundamental questions that, when answered, will provide direction to all disposition paths and enable the programs to move forward.

\section{Should the Am/Cm be thrown away?}

No.

This question continues to be raised, with the outcome from this study supporting the analysis completed last December $r^{(8)}$ and other studies previous to the December study, i.e. keep the Am/Cm material. The basic reasons being:

The material has been designated as "programmatic", which indicates agreement with stakeholders that the material should be used to support existing and potential future programs.

The ES\&H aspects do not discriminate between either storage or disposal.

The cost to store the material is less then to throw it away.

Should the Am/Cm be stored at ORNL?

Yes: Mk 18s (vitrified) \& Slugs/Other

Yes: Tank 17.1 solution (vitrified), if SRS does not build a Transfer and Storage Facility 
The total quantity of vitrified Mk 18 s and "Slugs/Other" can be accommodated by current ORNL storage. Very minimal modifications may be required and the material may be shipped utilizing existing processes and procedures.

Cutting and repackaging the Mk18s is not preferred due to the unknown nature of the material condition (creating contamination potentials and shielding issues if not engineered properly), and the availability of storage at ORNL (currently occupied space must be emptied, storage module D\&D'd and new storage installed, therefore about 7 to 10 years before storage is available). Dissolving Mk $18 \mathrm{~s}$ via a new dissolver was evaluated as a worse case $\mathrm{F}$ canyon option to provide the comparison to repackaging and was still preferred. Once the decision to process the Mk $18 \mathrm{~s}$ is made, a concentrated study of exiting capabilities with F Canyon should be made since it is possible that a nitric acid dissolution (proven previously) may be utilized. This would reduce the costs and schedules for dissolving the Mk 18 s appreciably.

Storing the Tank 17.1 vitrified solution at ORNL is about equal overall to storing at SRS, if SRS does not build a Transfer Storage Facility (currently being evaluated). Since the material is envisioned as being used by ORNL, it probably should be stored there. But, if a TSF is built at SRS, the additional cost for dry storage is considerably less initially and over the life cycle then storing at ORNL. Also, if the TSF is built, the concept of adding modules for other materials could become valuable to DOE for storing other assets as the complex is downsized. This capability would probably not be available at ORNL, since their storage would be full.

\section{How fund the recommended disposition paths?}

Not evaluated.

Determining funding was not within scope of this study, but projected planning level cash flows are shown to assist with the any cost impact analysis (see figure at the end of this section). Without overstating the obvious, if funding was obtained above the current projected $A O P$, experienced manpower could become an issue.

Overview continued -

The major scope for dispositioning the Am/Om materials is in the "material handling area". While technically challenging issues exist, as is true for any task dealing with radioisotope materials, none are as complicated as the current project/program for vitritication of the Am/ $\mathrm{Cm}$ solution.

The baseline for the "Slugs/Other" is the viable option with no alternatives identified passing simple screening. Currently planning activities should be successful at dispositioning the Slugs/Other to ORNL.

The baseline path currently in the draft EIS and 2006 Plan for dispositioning the Mark 18s is probably not the best approach. The Mark 18 s should be dissolved, made into glass, then shipped to ORNL. If a project to install a dissolver is required and project becomes a line item and follows the typical schedule for a line item of this complexity, about five years would be required to complete the project and another six months to process the material to glass. The Mark $18 \mathrm{~s}$ could be removed from RBOF in about six months by being transferred directly from RBOF to $F$ Canyon, versus the $~-$ eighteen months in the current RBOF planning schedule for transfer to ORNL. This would reduce the overall RBOF scope requiled to be completed prior to RBOF closure. F Canyon scope would increase slightly, but all functions needed would still be operational for other currently planned or projected activities. If the Mark 13s had to be removed from RBOF prior to the dissolver project being completed, storage within $F$ canyon could be evaluated (dry or wet). As the dissolving schedule moves further out in time an issue may be created with availability of $F$ Canyon functions if D\&D has progressed. 
The baseline path for the Tank 17.1 solution was not well defined in the 2006 plan or the EIS, but the intent was shown for the material to be maintained as "programmatic". This material could be safely, economically stored in MPPF until the need to remove from $F$ Canyon was determined. If the material is to be removed from $F$ canyon within the next 5 to 10 years, storage at SRS or ORNL should be developed now. This is an excellent material for consideration as a "National Asset", a class of material being suggested by the NMI project to maintain certain materials for an extended time period beyond currently active programs. Dispositioning this material as "Waste" would add costs, increase the time frame before final decisions could be made, and should require review of stakeholders that are currently knowledgeable that the material has been designated "programmatic", i.e., having value to programs to justify maintaining it's availability to current and future programs.

\subsection{Conclusion}

This study concludes the following:

- All disposition paths evaluated are technically feasible (cutting of Mk18's in RBOF is feasible, but strongly not recommended).

- All disposition paths evaluated have manageable Environmental, Safety \& Health (ES\&H) and Programmatic Risks (cutting of Mk18s being the least desirable).

- All SRS Am/Cm bearing materials could be removed from SRS prior to the end of FY2005, but some will likely remain until at least FY2008 (primary limiting factors: obtaining programmatic decisions pertaining to funding and priority, i.e. not technical issues).

- If F-Canyon PUREX process Decontamination and Decommissioning (D\&D) is initiated, Am/Cm disposition will not be a limiting factor ( $F$ Canyon required functions will still be available).

- To enable removal of all Am/Cm from SRS in the minimum time frame (by FY2006) the following would be required immediately:

- Additional funding $(\sim \$ 400 \mathrm{~K})$ and priority to enable completion of Pre-Conceptual Project activities prior to the end of FY1998.

- Funding $(\sim 4 M)$ and priority to enable various $R \& D$ and project activities to proceed in FY99.

\subsection{Recommendations}

This study recommends the following:

- Shipment to ORNL should be from F Canyon, i.e., not using the SRS Receiving Basin for Offsite Fuels (RBOF) and assuming the Am/Cm glass product from Tank 17.1 "solution" is shipped to Oak Ridge National Laboratory (ORNL)

- Interim storage of the Am/Cm glass product from Tank 17.1 "solution" at SRS should be seriously considered.

- The Mk18's should be processed to glass, i.e., sent from RBOF to F-Canyon for processing, then shipped to ORNL.

- The Slugs/Other Am/Cm bearing materials should be packaged at RBOF for direct shipment to ORNL.

\subsection{Path Forward Recommendations}

To ensure the program moves forward as outlined, obtaining the following agreements and decisions is recommended:

- Agreement to install CwP welder in MPPF during current project (i.e. start project design efforts by $1 / 1 / 99)$

- DOE-SR obtains required funding to initiate DMM project

- DOE-SR directs WSRC to initiate project development by October 1998 
- Agreement to develop Mark 18 glass flowisheet as soon as the current development is complete (i.e. starting $1 / 1 / 99$ )

- Decision supporting long term (>50yrs) storage at ORNL

- DOE-SR and DOE-OR reach agreement on program scope and funding

- DOE-OR obtains required funding $(\$ 7 \mathrm{M}+)$

- DOE-OR directs ORNL to initiate project development, including NEPA reviews, before FY 1999

- Decision supporting processing MK18's earlier (i.e. @ SRS, not @ ORNL)

- DOE-SR obtains required funding

- DOE-SR directs WSRC to initiate NEPA Check List development by October 1998

- DOE-SR directs WSRC to initiate project development by October 1998

- Decision accepting shipments from F-Canyon to ORNL (eliminates F-Canyon to RBOF shipments)

- Coupon testing initiated early in FY9S

The following graphically depicts the schedules developed for a technically possible and minimum expected scenario: 
Technically Possible Schedule

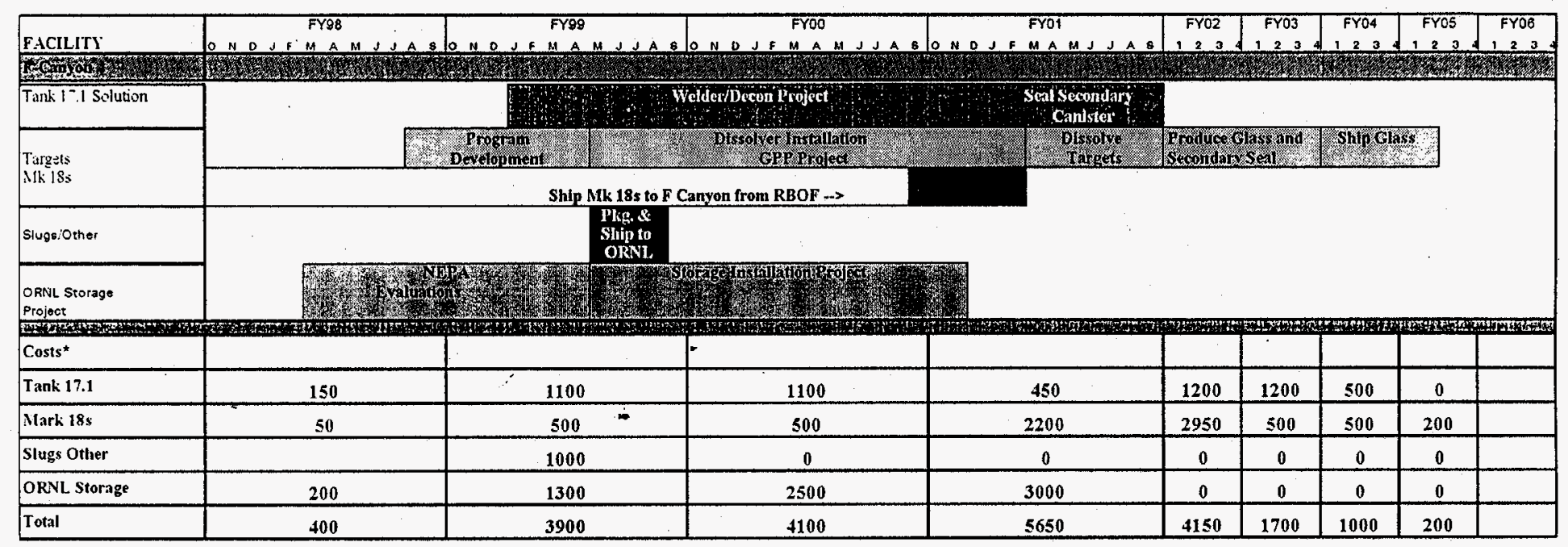

* Cost are avernges (in thousands of FY 98 dollars) based on estimates $(-50 \% /+100 \%$ accuracy) 


\section{Minimum Expected Schedule}

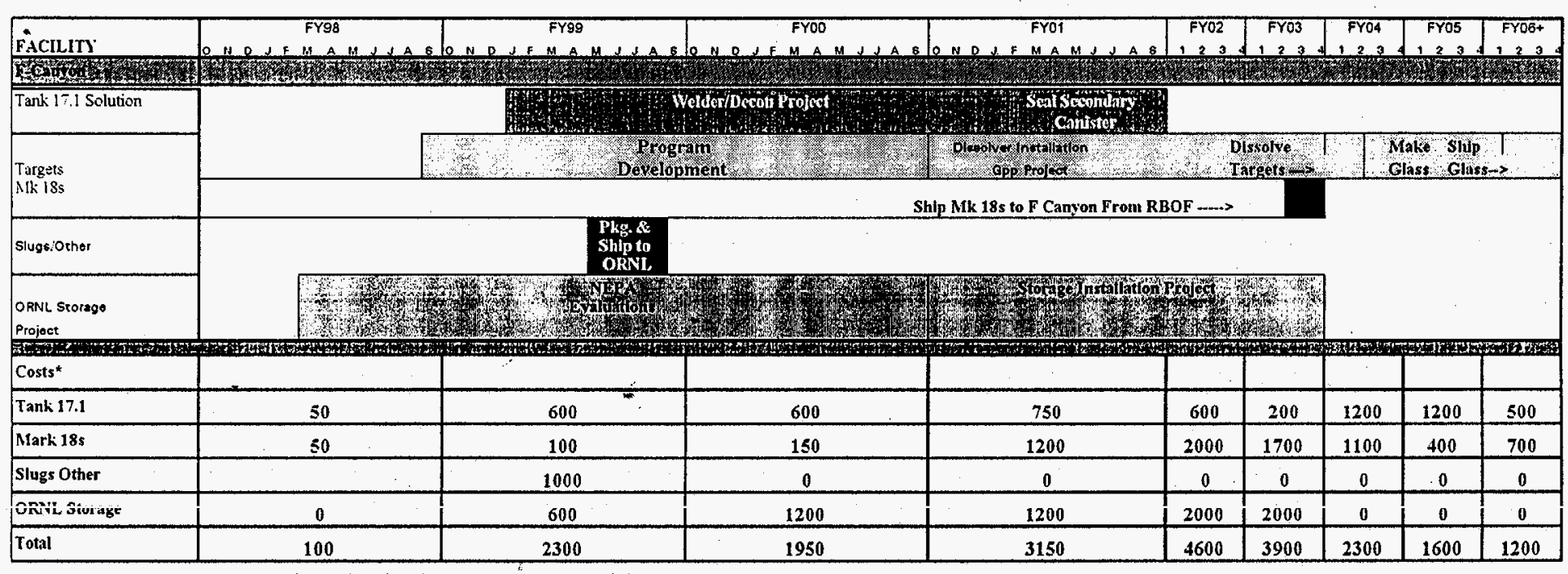

* Cost are averages (in thousands of FY 98 dollars) based on estimates $(-50 \% 1+100 \%$ accuracy) 


\subsection{SYSTEM ENGINEERING PROCESS APPLICATION}

The systems engineering approach utilized assesses the potential of a number of alternatives to meet the programmatic requisites for dispositioning the Am/Cm located at SRS. The process was developed for the NMI Project and utilized in development of the U. S. Department of Energy Savannah River Accelerated Cleanup Plan (Preliminary Draft Plan), January 1998. The study was made over a six week time period.

A core team composed of personnel from WSRC-PE\&CD Systems Engineering and Site Strategic Planning was created to perform required analyses and document the study (Appendix C). A group of "Domain Experts" (Appendix D), with knowledge and experience representing a wide-range of expertise for handling and processing radioactive materials as well as general engineering applications, was established to support the Core Team. "Reviewers" were established to perform additional reviews of the drafts and final study.

The core team assessed the assigned high-level programmatic functions and requirements and evaluated the need for a formal decision analysis process, i.e. Multi-attribute Decision Analysis (MDA), or Analytical Hierarchy Process (AHP), but decided the paths being evaluated did not require such a process. The team established a number of alternatives that were judged to have a potential for meeting all, or most, of the programmatic requisites. The alternatives were then judged as to propensity for meeting each of the highlevel programmatic requisites, and the resulting decisions are highlighted in this study's executive summary and conclusion section.

\subsection{Problem Statement}

The Am/Cm materials within SRS have been deemed "programmatic". The Am/Cm isotopes are used in the production of Californium-252, which is a neutron source used for radiography, nuclear medicine, and for research. The Am/Cm bearing "target" material and "slug/other" material will be used up by existing envisioned ORNL supported programs. The Am/Cm "solution" material, however, is a quantity large enough to exceed current program needs, and therefore could be considered a "national asset" or reclassified as waste. If the designation of "programmatic" was rescinded, and the material not considered a "national asset", the solution would have to be analyzed to determine how it could be treated as waste. An existing program to vitrify the $A m / C m$ solution had difficulties with R\&D, which created concerns within DOE on the overall existing Am/Cm "solution" program costs and schedules. In addition to perceived complications with the vitrification program, plans for dispositioning all three of the $\mathrm{Am} / \mathrm{Cm}$ material groups (solution, Mk $18 \mathrm{~s}$, slugs/other) are not well enough defined to enable the programs to move forward.

All Am/Cm material located at SRS is envisioned for transfer to ORNL for use in current and future programs. ORNL has enough controlled environment space for the total quantify of material, but modifications will be required to add specific storage modules. The $A m / C m$ program must also be integrated with a potential near-term ORNL mission that would utilize the same storage/processing space.

The "envisioned" strategy for dispositioning the SRS Am/Cm materials is being evaluated to provide a sound basis for planning the program to remove the materials from SRS and enable their use for future and existing programs. This study is being driven by uncertainties identified by DOE-SR regarding the storage of the product materials at ORNL, the status of the $A m / C m$ as a programmatic material, and the current disposition program progress. The primary concerns are the potential program impact on F-Canyon closure, overall program costs, and environmental/safety and health (ES\&H) vulnerabilities.

\subsubsection{Strategy}

The strategy for performing this study included:

- establishing a core team within WSRC PE\&CD responsible for conducting the study, the intent being some independence from the sponsoring organization (WSRC-NMSS) 
- establishing a WSRC and ORNL team of process, project and programmatic knowledgeable experts, referred to as "domain experts"

- establishing a WSRC and ORNL team of reviewers, referred to as "reviewers"

- utilizing an NMI Project Systems Engineer (provided by INEEL) to overview the study and provide guidance on application of NMI evaluation process and independent review of the teams process, and analysis techniques

- utilizing the NMI Project evaluation process (same process being used across DOE complex for material disposition studies) for evaluation of disposition path maturity, programmatic risks and environmental safety \& health (ES\&H) concerns

- conducting meetings to develop base case and alternative disposition strategies for each material type, focusing on fundamental SE processes to capture the functions, requirements, interfaces, etc..

- utilizing the EM 2006 Plan and current site plans to establish the framework for the base cases being developed

- evaluate using a multi-attribute decision analysis to rank the alternatives relative to their perceived probability of achieving program goals

- applying a graded systems engineering approach to add additional structure to the re-evaluation with resultant benefits

- issuing a draft report about four weeks after the study began to all domain experts and reviewers for their final input

- issuing a final report six weeks after study initiation

\subsubsection{Initial State}

Am/Cm materials are being stored safely within the Savannah River Site; Tank 17.1 Solution within $\mathrm{F}$ Canyon (after currently active project/program will be stored as "glass"), Mark 18s and "Slugs/Other" being stored in RBOF under water.

\subsubsection{Final State}

All materials identified in this study will have been, processed and converted to a stable physical form, removed from SRS, and placed in storage at CRNL, with some processed by ORNL to forms desired by customers. ORNL will continue storing the material, and periodically removing material from storage for processing to produce isotopes desired by custoiners.

\subsubsection{Goals/Objectives}

The goals and objectives are based on the NMI Project goals ${ }^{(5)}$ and the requesting DOE-SR letter (Appendix A).

\subsubsection{Reduce Risks}

- Reduce potential Environmental/Safety and Health risks

- Minimize potential programmatic risks

- Minimize potential technical risks

\subsubsection{Minimize Costs}

- Minimize DOE Complex wide, life-cycle disposition costs

- Minimize production of additional waste products/streams

\subsubsection{Reduce Schedules}

- Ensure canyon D\&D schedule is not impacted by $\mathrm{Am} / \mathrm{Cm}$ disposition

- Minimize schedules where nuclear facilities are utilized

- Minimize the required facilities for $\mathrm{Am} / \mathrm{Cm}$ disposition 
6.1.4.4 Recommend fully integrated management strategies

- Cover complete life-cycle, cradle to grave

- Provide a well documented, sound basis

- Ensure quantities, characteristics, and locations of materials are well known

- Preserve the integrity and credibility of the United States relative to its international agreements

- Identify future use options with recommendations for designation as "programmatic" or "national asset" material(s)

- Identify disposal options

\subsection{Functions}

"Product" Functions

- Store Am/Cm materials short term at SRS

- Process material through SRS Facilities

- Ship/move material (within Canyon, On-site outside Canyon, off-site)

- Store stabilized material long term

- Process material to end state customer desired form

- Dispose of used products

"Program" Functions

- Obtain logistics modifications to support operation of the chosen disposition option. (Prepare procedures, train personnel, conduct Operational Readiness reviews (ORR, etc.)

- Obtain programmatic decisions/agreements (EIS, ROD, mission approval, funding, etc.)

- Perform capital modifications to facilities to support chosen disposition option.

\subsection{Requirements}

The following are requirements that the alternative must satisfy in order to meet current programmatic goals.

- Material must be in a solid form ${ }^{(9)}$ for shipment off-site if the contained material has greater than 20 curie Pu content

- Material must be placed in a form that, at the minimum, will "ensure the continued safe storage of the nuclear materials for the next ten years" ${ }^{(10)}$

\subsection{Interfaces}

- DOE-EM, NE \& ER

- Storage at ORNL and product package (canister package)

- RBOF \& F-Canyon

\subsection{Assumptions}

- The current program for placing $\mathrm{Am} / \mathrm{Cm}$ solution into glass canisters is successful.

- Material will be placed in a form that, at the minimum, will ensure the continued safe storage of the nuclear materials for 40 years.

- The isotopic content (desired by ORNL) of the solution will be recoverable from the stabilized form

- Current operations continue to cover sunk facility costs, that is costs for this study were estimated as incremental increases over current operations

- An existing shipping cask, that can be handled by SRS and ORNL, can be certified for shipment of the Am/Cm materials from SRS to ORNL in a timely fashion (not impact schedules defined in the disposition paths).

- DOE will be able to remove organizational barriers and establish consensus on the program scope and responsibilities during FY98. 
- Funding is allocated in FY99 to complete pre-conceptual planning, conceptual design and begin project execution.

\subsection{Issues}

- ORNL must evaluate their current Authorization Basis and existing NEPA basis to ensure that no issues pertaining to long term storage exist.

- Canyon decommissioning plans impacted by the continued presence of Am/Cm within F-Canyon, RBOF and/or K/L Reactor Basin. Functions required for removal of vitrified Am/Cm could be "energized' to be available, but as the schedules are extended this could become a major issue.

- $\mathrm{Am} / \mathrm{Cm}$ is currently designated as "Programmatic Material", and as such should be available for future use, not discarded. If disposal of the material is desired, the designation "Programmatic" will need to be changed with the appropriate approvals, which could add substantial time to the program to disposition the Am/Cm solution.

- One outcome of changing "Programmatic" to "Waste " designation would be RCRA issues that would have to be addressed for continued storage at SRS facilities.

- The quantity of $\mathrm{Am} / \mathrm{Cm}$ that could be available for reuse is enough to fill current needs for at least 50 years. However, new uses could be developed in the future creating an increased demand for the material. The cost to produce this material in the future would be extremely high (billions of dollars) and therefore it is unlikely that the material would ever be made again.

- Funding has not been allocated to devielop long-term storage and/or disposal.

- Requirements based on the IMNM EIS and subsequent ROD's could be changed, if the EIS and ROD development process was revisited. This could have a major impact (negative or positive) on potential alternatives and associated costs and schedules.

- No off-site shipping cask is currently certified for shipment of the Am/Cm materials. A cask will have to be rented (or purchased), and certified for these materials. If any issues arise pertaining to the certification and or rental schedules and costs could be impacted drastically.

\subsection{Am/Cm Disposition Path's Overviews}

The following overview descriptions were developed by the core team members based on input received from domain experts and reviewers and through analysis of data. These descriptions summarize each disposition path. An expanded review of each case shown below including functions, requirements, interfaces, issues, assumptions, and costs is provided in Appendix I. Each disposition path was reviewed prior to performing the Nuclear Materials Integration (NMI) project Disposition Path Maturity (DPM) evaluations (Appendix $L$ ). The descriptions were completed prior to performing Programmatic Risk (PR) Environmental, Safety, and Health (ES\&H) evaluations and to conducting the decision analysis.

Overviews of the SRS Am/Cm Tank 17.1 "Siolution" disposition paths are provided in Sections 6.7.1 through 6.7.6. The options discussed in Section 6.7.6 disposition the solution to a national repository. All other options disposition the solution to ORNL.

The overviews of the SRS Am/Cm "Mk 18" disprosition paths are in Sections 6.7.7 and 6.7.8.

The SRS Am/Cm "Slugs/Other" disposition path is defined in Section 6.7.9.

Additional options considered but screened from further analysis are defined in Section 6.7.10.

NOTE: Options that disposition Am/Cm solutions to ORNL do not evaluate functions beyond "Storage @ ORNL". The storage Operations/Maintenance/D\&D, etc. costs and all downstream functions are assumed to be covered by the existing ORNL programis supporting development of special radioisotopes. The scope of providing storage for the "Am/CM Solution" glass canisters is addressed as an incremental increase over current storage capacity at OFINL. The ORNL has adequate storage for the Mk18s (if placed into glass) and "Slugs/Other".

Review of Appendix $\mathrm{H}$ will assist the reader with understanding of the following sections. 


\subsubsection{Tank 17.1 "Solution" Disposition - Base Alternative (double containment, MPPF-RBOF- ORNL)}

\section{MPPF Primary, RBOF Secondary Containment, Shipped From RBOF to ORNL}

The base alternative for the Americium and Curium $(A m / C m)$ disposition begins with $A m / C m$ solution stored in F-Canyon Tank 17.1. The solution is pretreated with oxalic acid to remove transition metals, such as $\mathrm{Cr}, \mathrm{Ni}$, and $\mathrm{Fe}$, and is transferred to a feed tank in the Multi-Purpose Processing Facility (MPPF) for vitrification. Vitrification is a batch feed process at the end of which the molten glass drains from the melter into a "canister" (Appendix H, section 9.8.2, Figure 1). The canister is sealed but does not provide a containment boundary. The canisters are lag stored in the MPPF after being loaded into a carrier.

The canisters will be retrieved from MPPF lag storage and placed into a qualified shipping container (CwP-1) (Appendix H, section 9.8.2, Figure 2.1). A cover will be placed on the CWP-1, and the container will be sealed by a full penetration closure weld using a welder installed in an MPPF cell. The CwP-1 then will be lag stored in MPPF. Prior to shipment to RBOF, the CwP-1 will be decontaminated (using existing F-Canyon decontamination area) and placed in an onsite shipping cask. The CwP-1 will be stored in RBOF until shipped to ORNL for subsequent storage and use.

Figure 6.7.1

Functional Flowsheet for Tank 17.1 "Solution" Disposition - Base Alternative
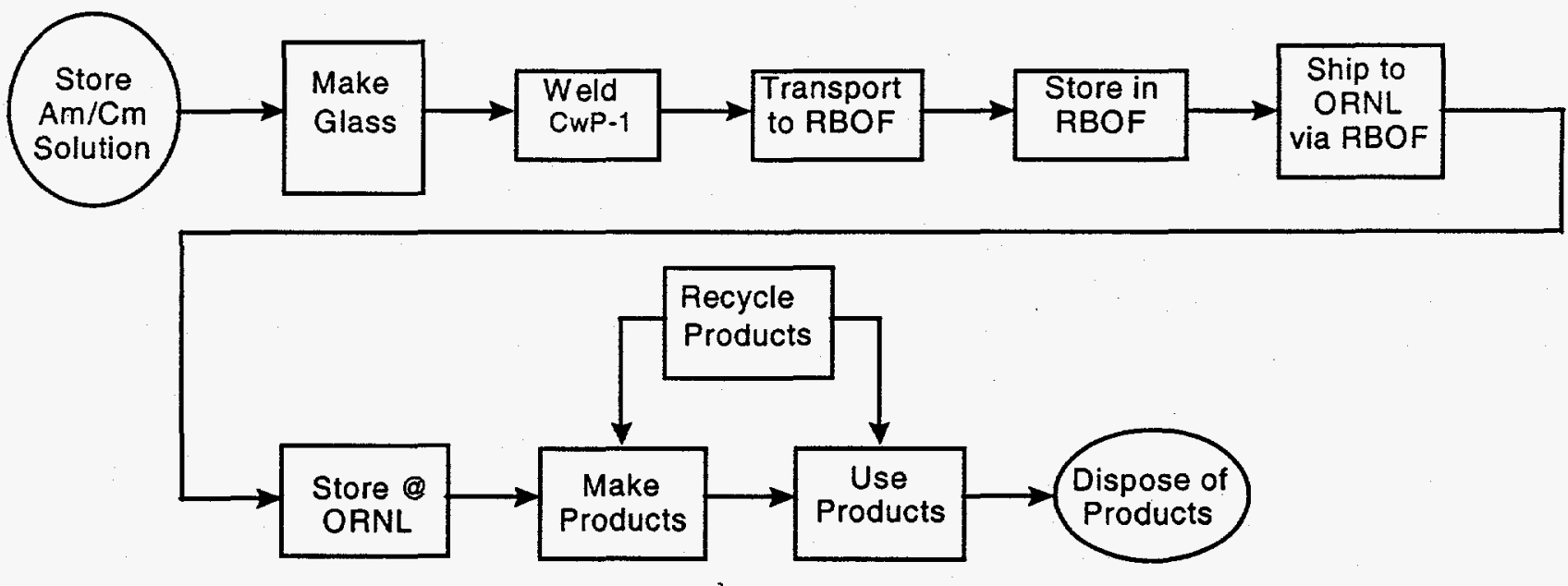

\section{Cost -}

- Planning level estimated total life-cycle cost $=\$ 92 \mathrm{M}: \quad(\$ 80 \mathrm{M}$ (existing program) $+\$ 4.6-5.5 \mathrm{M}$ (SRS)

$+\$ 7 M$ (ORNL expand storage facility)

\section{Enabling Objectives}

- Obtain funding for further process and equipment development

- Complete R\&D project on schedule

- Design and install welder in F-Canyon

- Design and licensing of containment cask for shipment of $\mathrm{Am} / \mathrm{Cm}$ to ORNL

- Add storage area to ORNL.

- Current ORNL, radioisotope program continues to be funded

- Fund operation of $\mathrm{F}$ Canyon systems required to support $\mathrm{Am} / \mathrm{Cm}$ disposition 


\subsubsection{Tank 17.1 "Solution" Disposition - Alternative \#1 (double containment, RBOF-ORNL) MPPF Contamination Control Can, RBCIF Primary \& Secondary Containment, Shipped From RBOF to ORNL}

Alternative One disposition begins with $\mathrm{Am} / \mathrm{Cm}$ solution stored in F-Canyon Tank 17.1. The solution is pretreated with oxalic acid to remove transition metals, such as $\mathrm{Cr}, \mathrm{Ni}$, and $\mathrm{Fe}$ and is transferred to a feed tank in the MPPF for vitrification. Vitrification is a batch feed process at the end of which the molten glass drains from the melter into a "canister" (Appendix H, section 9.8.2, Figure 1). The canister is sealed but does not provide a containment boundary. The canisters are lag stored in the MPPF after being loaded into a carrier.

The canisters will be retrieved from lag storage and placed into a container for transport to RBOF via the site transport cask. In RBOF, the canisters will be placed in a container that provides contamination control (CwP-3) Appendix H, section 9.8.2, Figure 2.2)). A cover will be placed on the CwP-3, and the container sealed by a full penetration closure weld using a welder installed in RBOF. The CwP-3 will be purged of water, back filled with helium, and sealed shut. Next, the CwP-3 will be placed into a mechanically sealed primary shipping container (msQSC) (Appendix $H$, section 9.8.2, Figure 4), purged of water, back filled with helium, sealed stiut and moved to lag storage. The mSQSC then will be retrieved, placed in an off-site shipping cask, and shipped to ORNL. ORNL will remove the msQSC from the shipping cask assembly and store the Am/Cm glass in situ in the CWP-3.

Figure 6.7-2

Functional Flowsheet for Tank 17.1 "Solution" Disposition - Alternative \#1

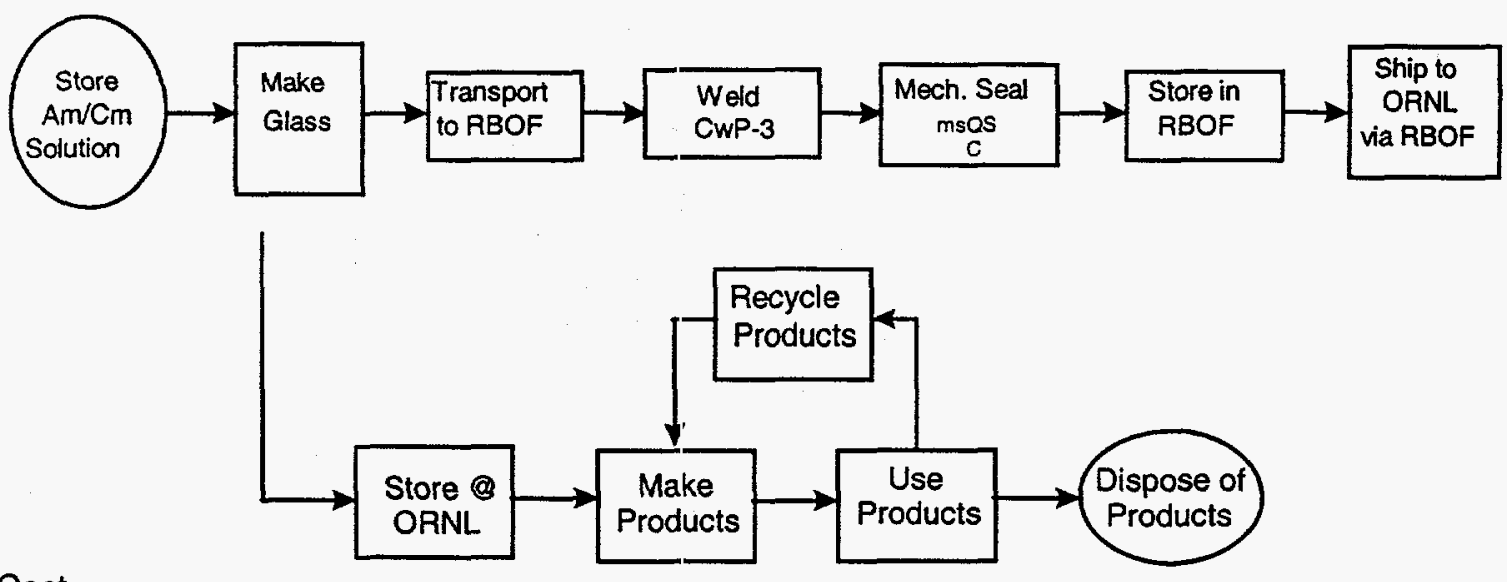

Cost

- Plañning level estimated total life-cycle clost $=\$ 94 \mathrm{M}: \quad[\$ 80 \mathrm{M}$ (existing program) $+\$ 5.9-6.9 \mathrm{M}(S R S)+$ $\$ 7 M(O R N L)]$

Enabling Objectives

- Obtain funding for further process and equipment development

- Complete R\&D project on schedule

- Design and install welder in RBOF

- Design and licensing of containment cask for shipment of $A m / C m$ to ORNL

- Add storage area to ORNL

- Use base case

- Fund operation of $\mathrm{F}$ Canyon systems required to support $\mathrm{Am} / \mathrm{Cm}$ disposition 
WESTINGHOUSE SAVANNAH RIVER COMPANY

Americium/Curium Disposition Life Cycle Planning Study(U)
Document: NMP.PLS-980044

Revision 0

April 30, 1998

Page 29 of 159

\subsubsection{Tank 17.1 "Solution" Disposition - Alternative \#2 (double containment, MPPF-ORNL)}

\section{MPPF Primary- Cask Secondary Containment ,Shipped From F-Canyon to ORNL}

Alternative Two disposition begins with $\mathrm{Am} / \mathrm{Cm}$ solution stored in $\mathrm{F}$-Canyon Tank 17.1. The solution is pretreated with oxalic acid to remove transition metals, such as $\mathrm{Cr}, \mathrm{Ni}$, and $\mathrm{Fe}$ and is transferred to a feed tank in the MPPF for vitrification. Vitrification is a batch feed process at the end of which the molten glass drains from the melter into a "canister" (Appendix $\mathrm{H}$, section 9.8.2 Figure 1). The canister is sealed but does not provide a containment boundary. After being loaded into a carrier the canisters are lag stored in the MPPF.

The canisters will be retrieved from lag storage and placed into a shipping container (CWP-1) (Appendix $H$, section 9.8.2, Figure 2.1). A cover will be placed on the CwP-1, and the container will be sealed by a full penetration closure weld using a welder installed in a MPPF cell. The CwP-1 will be decontaminated and placed in a off-site shipping cask. The shipping cask will be decontaminated and shipped to ORNL. ORNL will remove the CWP-1 from the shipping cask assembly and store the Am/Cm glass in situ in the CWP-1.

Figure 6.7-3

Functional Flow Sheet for Tank 17.1 "Solution" Disposition - Alternative \#2

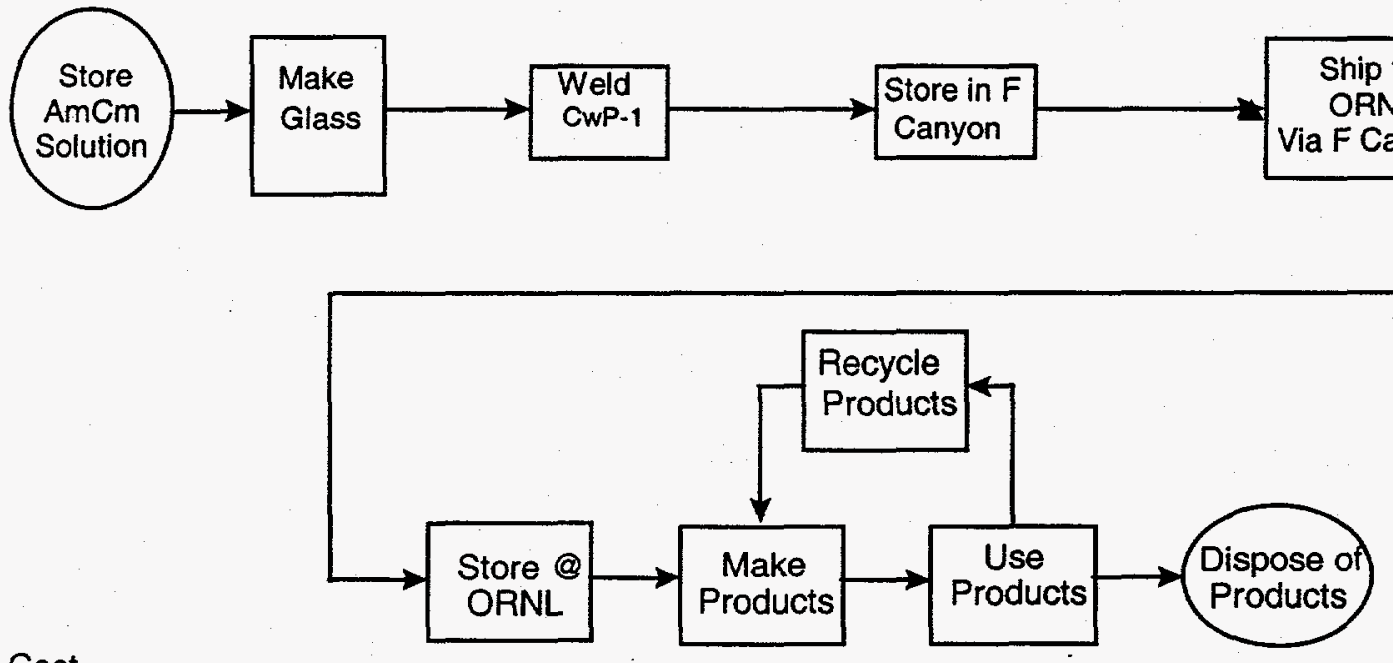

Cost

- $\quad$ Planning level estimated total life-cycle cost $=\$ 92 \mathrm{M}: \quad[\$ 80 M$ (existing program) $+\$ 4.4-\$ 5.2 M$ $(S R S)+\$ 7 M(O R N L)]$

\section{Enabling Objectives}

- Obtain funding for further process and equipment development

- Complete R\&D project on schedule

- Design and install welder in F-Canyon

- Design and licensing of a containment cask for shipment of $A m / C m$ to ORNL

- Add storage area to ORNL

- Fund operation of $\mathrm{F}$ Canyon systems required to support $\mathrm{Am} / \mathrm{Cm}$ disposition 


\subsubsection{Tank 17.1 "Solution" Disposition - Alternative \#3 (single containment, MPPF-ORNL)}

\section{MPPF Contamination Control Can - Shipping Cask Primary Containment, Shipped From F. Canyon to ORNL}

Alternative Three disposition begins with $\mathrm{Am} / \mathrm{Cm}$ solution stored in $\mathrm{F}$-Canyon Tank 17.1. The solution is pretreated with oxalic acid to remove transition metals, such as $\mathrm{Cr}, \mathrm{Ni}$, and $\mathrm{Fe}$ and transferred to a feed tank in the MPPF for vitrification. Vitrification is a batch feed process at the end of which the moiten glass drains from the melter into a "canister" (Appendix $H$, section 9.8.2, Figure 1). The canister is sealed but does not provide a containment boundary. The canisters are lag stored in the MPPF.

The canisters will be retrieved from lag storage in MPPF, seal welded in a contamination control canister (CwP-2) (Appendix H, section 9.8.2, Figure 2.2)) using a welder installed in an MPPF cell. The CwP-2 will be decontaminated and placed in a off-site shipping cask. The shipping cask will be decontaminated and then shipped to ORNL form F Canyon. ORNL will remove the CWP-2s from the shipping cask assembly and store the Am/Cm glass in situ in the CwP-2s. When needed, ORNL will remove a CwP from storage for processing the glass into products.

Figure 6.7-4

Functional Flow Sheet for AmVCM “Solution" Disposition - Alternative \#3

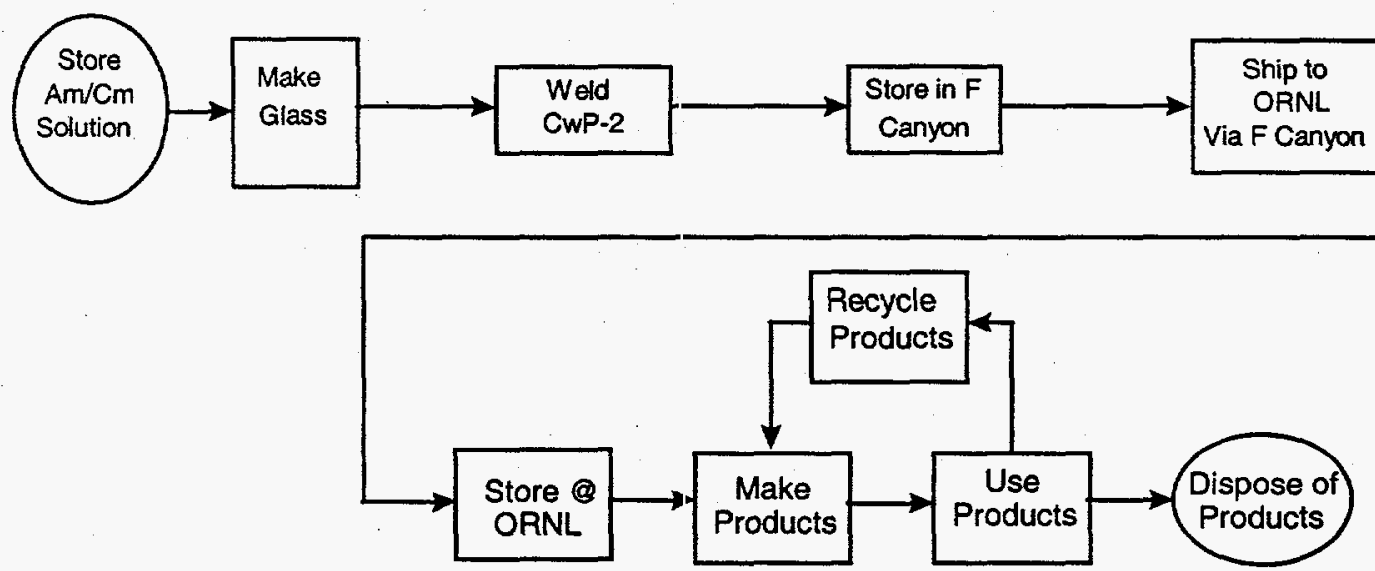

Cost

- Planning level estimated total life-cycle cost $=\$ 91 \mathrm{M}: \$ 80 \mathrm{M}$ (existing program) $+\$ 4 \mathrm{M}-\$ 4.8 \mathrm{M}$ (SRS) $+\$ 7 M(O R N L)$

Enabling Objectives

- Obtain funding for further process and equipment development

- Complete R\&D project on schedule

- Design and install welder in MPPF

- Design and licensing of a containment cask for shipment of Am/CM to ORN.

- Add storage area at ORNL

- Current ORNL, radioisotope program continues to be funded

- Fund operation of $\mathrm{F}$ Canyon systems required to support $\mathrm{Am} / \mathrm{Cm}$ disposition 


\subsubsection{Tank 17.1 "Solution" Disposition - Alternative \#4 (double containment, SRS Interim storage-ORNL)}

\section{Interim SRS Glass Storage, Transfer to ORNL As Needed}

Alternative Four begins with $\mathrm{Am} / \mathrm{Cm}$ solution stored in F-Canyon Tank 17.1. The solution is pretreated with oxalic acid to remove transition metals, such as $\mathrm{Cr}$, Ni, and $\mathrm{Fe}$ and transferred to a feed tank in the Multi-Purpose Processing Facility (MPPF) for the vitrification process. Vitrification is a batch feed process at the end of which the molten glass drains from the melter into a "canister" (Appendix $H$, section 9.8.2, Figure 1). The canister is sealed but does not provide a containment boundary. After being loaded into a carrier the canisters are lag stored in the MPPF.

The canisters will be retrieved from lag storage in the MPPF, seal welded into a primary shipping container (CwP-2), (Appendix H, section 9.8.2, Figure 2.1). and returned to MPPF for lag storage until $L$-Basin is ready to receive them. The CWP-2 will be transferred by on-site shipping cask from FCanyon to L-Basin.

In L-Basin the CWP-2 will be loaded into an msQSC, provided with a Helium atmosphere and sealed. Storage will be in the dry cask area until transport to ORNL on an as needed basis.

Figure 6.7-5

Flow chart: Tank 17.1 Solution - Interim Dry Cask Storage

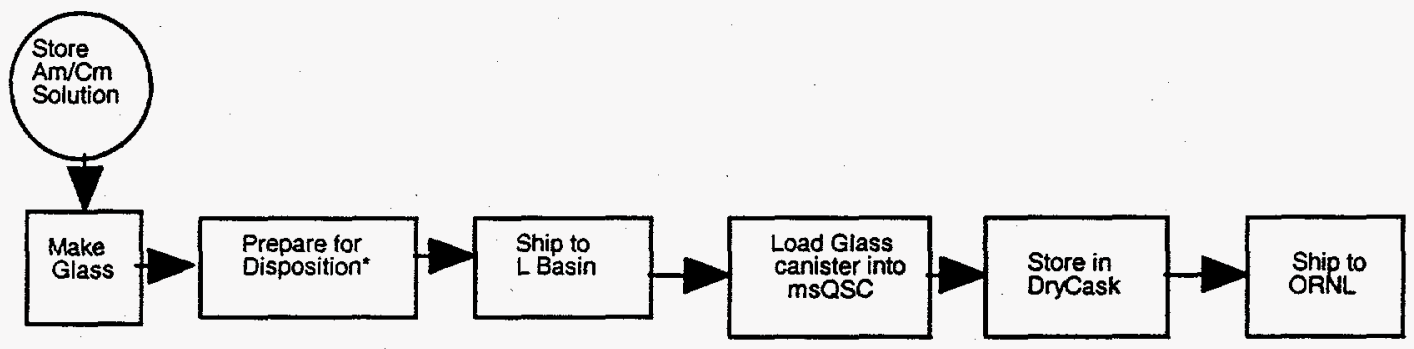

$\underline{\text { Cost }}$

- Planning level estimated total life-cycle cost $=\$ 86 \mathrm{M}$ : $\$ 80 \mathrm{M}$ (existing program) $+\$ 5.5 \mathrm{M}-\$ 6.9 \mathrm{M}$

(SRS welder, Spent fuel storage, canister and transport)

\section{Enabling Objectives}

- Obtain funding for further process and equipment development

- Completé R\&D project on schedule

- Design and install welder in F-Canyon

- Obtain NEPA coverage for storage in L Basin and dry spent fuel storage casks

- Obtain handling SNF canister handling equipment for ORNL

- Add Dry Storage near L-Basin

- Add storage area to ORNL

- Fund operation of $F$ Canyon systems required to support $\mathrm{Am} / \mathrm{Cm}$ disposition 


\subsubsection{Tank 17.1 "Solution" Disposition - Alternative \#5 (double containment, SRS interim storage-National Repository)}

The Am/Cm Tank 17.1 "Solution" waste case begins with Am/Cm solution stored in F-Canyon Tank 17.1. The solution is pretreated with oxalic acid to remove transition metals, such as $\mathrm{Cr}, \mathrm{Ni}$, and $\mathrm{Fe}$ and transferred to a feed tank, then vitirification via MPPF. Vitrification is a batch feed process at the end of which the molten glass drains from the melter into a "canister", (Appendix $\mathrm{H}$, section 9.8.2, Figure 1). The canister is sealed but does not provide a containment boundary. After being loaded into a carrier, the canister is lag stored in the MPPF.

The canisters are retrieved from lag storage in the MPPF, seal welded into a contamination control container (CwP-2) (Appendix H, section 9.8.2. Figure 2.2), and returned to MPPF for lag storage until LBasin is ready to receive them. The CWP-2 will be transferred by onsite shipping cask from F-Canyon to L-Basin.

In L-Basin the CwP-2 will be loaded into a Spent Nuclear Fuel canister, provided with a Helium atmosphere, welded closed, lag stored and finally transported to the repository (MGDS).

Figure 6.7-6

Functional Flow Sheet for Tank '17.1 "Solution" Disposition - Waste Alternative

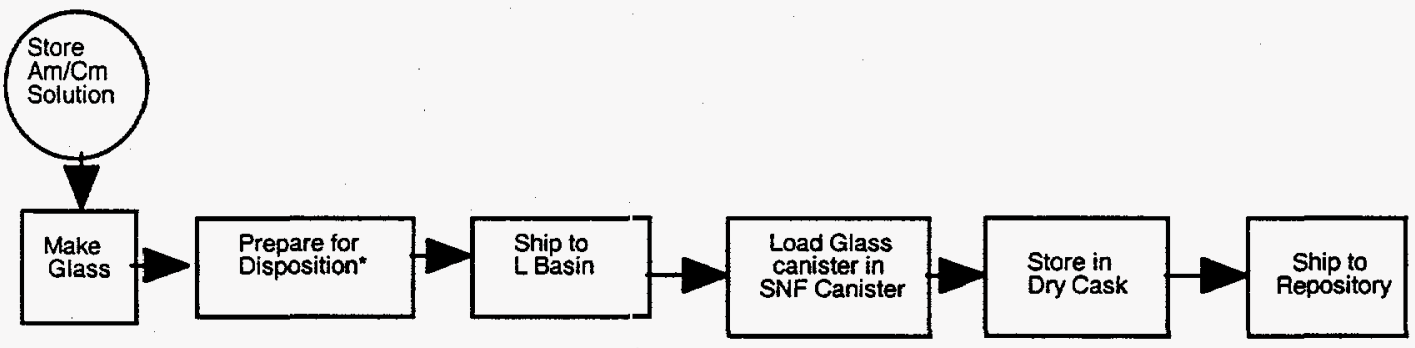

$\underline{\text { Cost }}$

- Planning level estimated total life-cycle cost $=\$ 120 \mathrm{M}$ : $\$ 80 \mathrm{M}$ (existing program) $+\$ 11 \mathrm{M}-\$ 51.6 \mathrm{M}$ (SRS, Glass waste qualification cost and welder) $+\$ 4.9-6.2 M$ (Spent fuel storage, canister and transport) $+\$ 2.4$ - 3.34M (Incorporation into repository)

\section{Enabling Objectives}

- Obtain funding for further process and ec|uipment development

- Complete R\&D project on schedule

- Design and install welder in MPPF

- Obtain NEPA coverage for storage in L Easin and dry spent fuel storage casks

- Obtain funding to qualify glass for the repository

- Add Dry Storage near L-Basin

- Fund operation of $F$ Canyon systems required to support $\mathrm{Am} / \mathrm{Cm}$ disposition 


\subsection{7. “Mark 18" Disposition - Base Alternative (double containment, RBOF-ORNL)}

\section{Cut Mk 18's in RBOF Basin and Ship to ORNL}

The base case for the Am/Cm Target (Mk 18) disposition begins with Mk 18's stored in RBOF. The Mk 18's are removed from their storage containers, then shortened by cutting in the RBOF basin. The fuel core is placed in a contamination control container (CWP-3), (Appendix $H$, section 9.8.2, Figure 2.3), provided with a helium atmosphere and sealed shut. Two CWP-3's are installed in an msQSC prior to mechanically sealing the msQSC. Two msQSC's are loaded into an onsite shipping cask. The onsite shipping cask assembly is then placed in an off-site transport cask that provides secondary containment for shipment. Shipment is to ORNL for subsequent storage and use.

Figure 6.7-7

\section{Am/Cm "Mark 18" Disposition - Base Alternative}

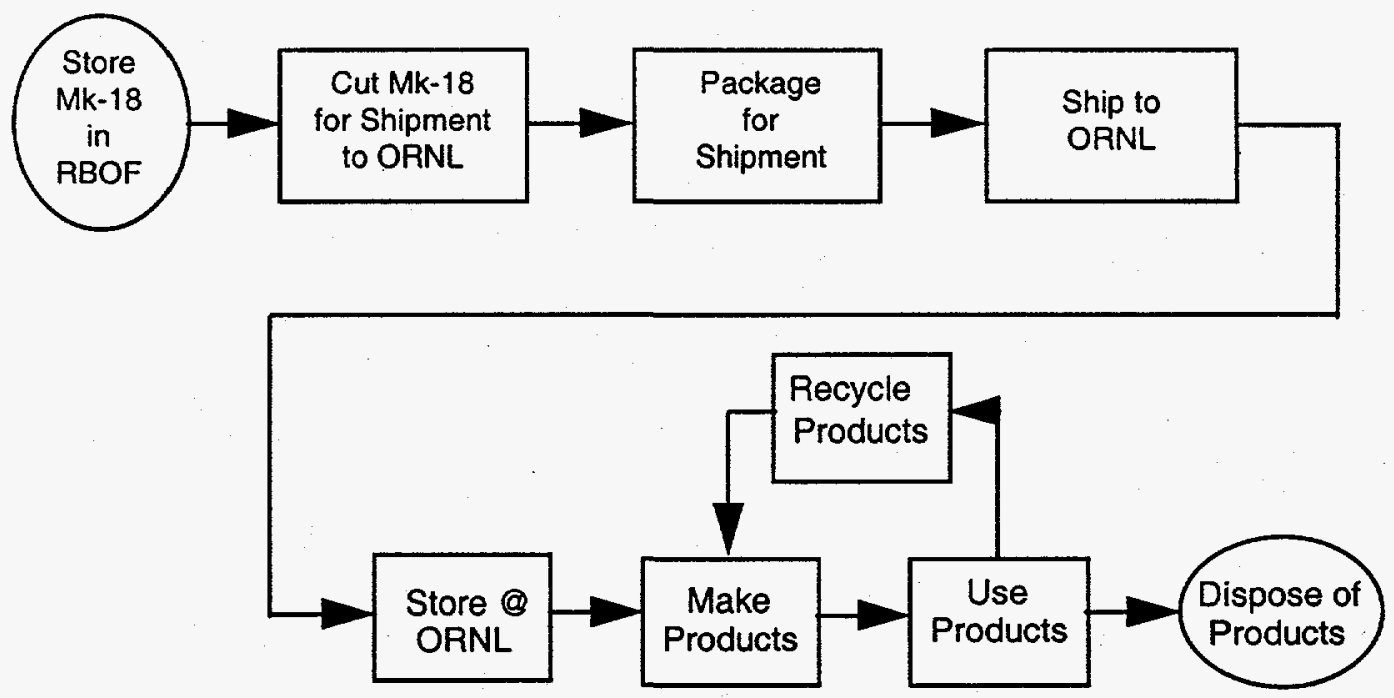

Cost

- Planning level estimated total life-cycle cost $=\$ 20 M$ : $\$ O M$ (existing program) $+\$ 17 M(S R S)+\$ 3 M$ (ORNL)

\section{Enabling Objectives}

- Obtain funding for further process and equipment development

- Design and install MK 18 cutting and packaging equipment in RBOF

- The design and licensing of transport cask for shipment of $A m / C M$ to ORNL

- Add storage area to ORNL

- Fund operation of $\mathrm{F}$ Canyon systems required to support $\mathrm{Am} / \mathrm{Cm}$ disposition 


\subsection{8. "Mark 18" Disposition - Alternative \#1 (make glass, single containment, MPPF-ORNL) Transfer to F-Canyon and Dissolve for Vitrification, Ship to ORNL}

Alternative One begins with the Mk 18s stored in RBOF. All Mk 18s are transported to F-Canyon for processing via the onsite transfer cask. Processing involves dissolving the Mk 18s, pretreating the Mk 18 slurry as necessary, storing the slurry in a feed tank, then vitrification via MPPF. The vitrification frit will be adjusted to enable this solution to be vitrified. Vitrification is a batch feed process at the end of which the molten glass drains from the melter into a "canister" (Appendix $\mathrm{H}$, section 9.8.2 Figure 1). The canister is then welded closed. After being loaded into a CWP-1 or 2 (Appendix $H$, section 9.8.2, Figure 2.1 or 2.2), the CWP-1 (or 2) is lag stored in MPPF. The glass path from solution to ORNL would be one of the alternative cases shown in Sections 6.7.1, 6.7.2, 6.7.3, or 6.7.4. When needed ORNL will remove a CWP form storage and process the glass to products.

Figure 6.7-8

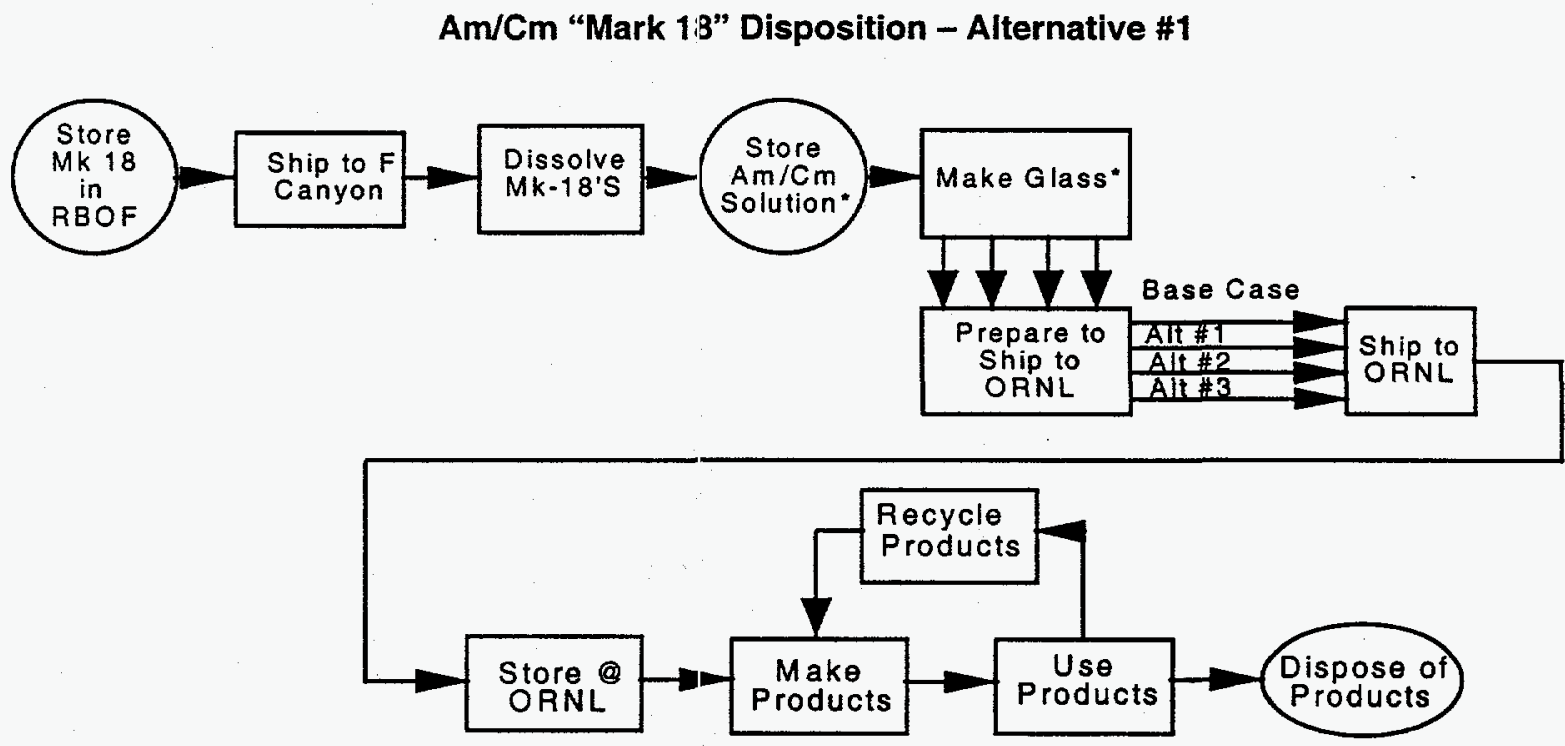

Cost

- Planning level estimated total life-cycle cost $=\$ 7.6$ : $[\$ O M$ (existing program) $+\$ 7.1-8.1$ (SRS) $-\$ 1 M$ (ORNL cost reductions from not having uraste stream associated with removal of $A()]$

Enabling Objectives

- Obtain funding for further process and equipment development

- Complete R\&D project on schedule

- Install appropriate tanks and jumpers in F-Canyon to support Mk 18 dissolution

- Design and install welder in F-Canyon

- Design and licensing of a containment cessk for shipment of Am/CM to ORNL

- Add storage area to ORNL

- Fund operation of $F$ Canyon systems required to support $\mathrm{Am} / \mathrm{Cm}$ disposition 


\subsection{9. "Slugs/Other" Disposition - Base Alternative (double containment, RBOF-ORNL)}

\section{Package Slugs In RBOF and Ship To ORNL}

The base case begins with Slugs/Other stored in RBOF and finishes at ORNL. The Slugs/Other are loaded into a CWP-3 (Appendix $H$, section 9.8.2, Figure 2.3), provided with an internal helium atmosphere, mechanically sealed into an msQSC, (Appendix $\mathrm{H}$, section 9.8.2, Figure 4), and lag stored pending shipment to ORNL. The msQSC will be retrieved and shipped to ORNL, where the CwP-3 will be removed for in situ storage and use. Existing msQSC equipment is utilized to load the package into the off-site shipping cask. When needed, ORNL will remove a CWP from storage and process the slugs/other material into user products.

Figure 6.7-9

"Slug/Other" Disposition - Base Alternative

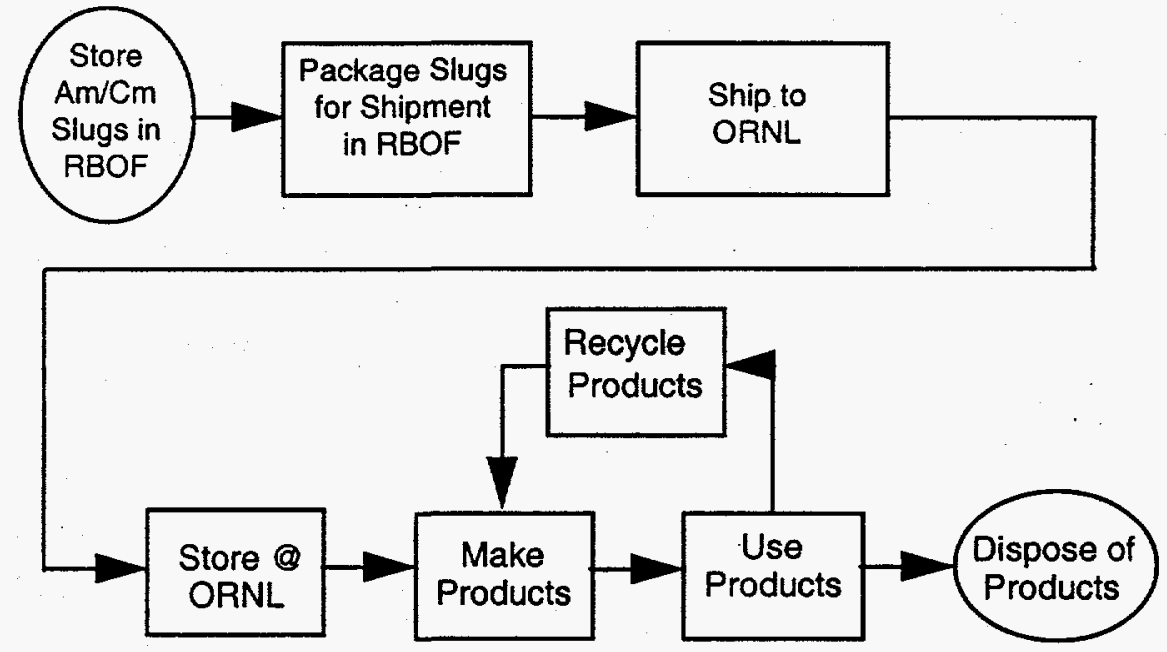

Cost

- Planning level estimated total life-cycle cost $=\$ 1 \mathrm{M}: \quad \$ 1 M(S R S)+\$ O M$ (ORNL costs covered by other programs)

\section{Enabling Objectives}

- Obtain funding for equipment development.

- The design and licensing of off-site shipping cask for shipment of Am/CM to ORNL.

- Add storage area to ORNL 


\subsubsection{Potential Alternatives not Evaluated}

The following scenarios were developed but not considered any further for disposition of $A m / C m$ Solution, Mk 18s, and Slugs/Other:

No Action: For a no action case, Am/Cm solution would remain in Tank 17.1, "Mk $18 \mathrm{~s}$ " and "Slugs/Other" would remain in RBOF. A no action alternative was considered for Tank 17.1 solution in the IMNM EIS and rejected. Therefore, it wals not considered in this analysis. If the solution was not removed, it would pose the additional problem that accountable materials with significant potential for environmental release would be left in F Caryon, potentially delaying its transition to cold status. In order to shut down RBOF, the Mk 18 s and Slugs/Other would have to be removed. Therefore, leaving these materials in RBOF was not considered.

Packaging of Mk18s at Hanford (PNNL): In the past, SRS Mk-42 targets were transported from RBOF to PNNL, where they were cut and packaged for shipment to ORNL and then processed at ORNL. Indications are that there is no interest for performing such an activity for the Mk18s, and the equipment used for the Mk-42s is no longer in service. As currently packaged, the Mk18s would fit in several existing shipping casks (either a NLI 1/2 or NAC LWT cask), but an evaluation of the Mk18s would be required to determine if they would require repackaging before being shipped off-site. Repackaging would involve many risks identified for cutting the Mk18s, which is another reason this option was not considered further.

Direct Shipment of Mk 18s to ORNL: Direct shipment of Mk 18s to ORNL from RBOF may be physically possible, but very impracticable. The internal cavity of an NLI 1/2 or NAC LWT cask is 178 inches long while the current configuration is 168 inches long uncut, which leaves minimal area for shielding on the ends, and minimal space if an additional packaging container becomes required around the current Mk18 storage configuration. Discussions with ORNL personnel indicated that they would have no way to store the material -- a new shield block would be required (the current block has selves with slightly more than 4 in inside diameter while the currently packaged Mk18s are 5.7 inches in diameter). An evaluation of the Mk18s would be required to determine if they would require repackaging before being shipped off site. Significant modifications, would also be required for the ORNL processing facility for cutting, since the current cells are $7^{\prime} X 7^{\prime} X 8^{\prime}$. Funding, NEPA, and current ORNL program missions would require extensive evaluation before proceeding. For these reasons, this alternative was not evaluated.

Vitrification of "Slugs/Other": The Slugs'Other materials could be sent from RBOF to the F-Canyon for processing using the Mk18s proposed pathway, i.e., processed, vitrified, then shipped. But, no significant issue exists with shipping the Slugs/Other material to ORNL, and the material may be stored and processed using existing ORNL facilities. Shipping direct to ORNL is the least complicated pathway. For these reasons, this alternative was not evaluated. 


\subsection{ACRONYMS, ABBREVIATIONS AND DEFINITIONS}

\begin{tabular}{|c|c|}
\hline $\begin{array}{l}{ }^{233} \mathrm{U} \\
{ }^{241} \mathrm{Am}\end{array}$ & $\begin{array}{l}\text { Uranium isotope } 233 \\
\text { Americium isotope } 241\end{array}$ \\
\hline $\mathrm{Am}$ & Americium \\
\hline $\mathrm{Cm}$ & Curium \\
\hline CwP-1 & Container with Pintle, approved shipping container \\
\hline CwP-2 & Container with Pintle, contamination control container \\
\hline CwP-3 & Container with Pintle, CwP-2 with method to remove water \\
\hline $\mathrm{D} \& \mathrm{D}$ & Decontamination and Decommissioning \\
\hline DNFSB & Defense Nuclear Facilities Safety Board \\
\hline DOE & Department of Energy \\
\hline DOE-SR & Department of Energy - Savannah River Office \\
\hline & Depleted Uranium \\
\hline EC & Evaluation Criteria \\
\hline ES\&H & Environmental/Safety and Health \\
\hline DWPF & Defense Waste Processing Facility \\
\hline HEPA & High-Efficiency Particulate Air \\
\hline HLW & High-Level Waste \\
\hline INMN & Interim Management of Nuclear Materials \\
\hline LCC & Life-Cycle Cost \\
\hline lag & Interim or "lag time" storage during a process \\
\hline$M$ & Million \\
\hline MPPF & Multi-Purpose Processing Facility \\
\hline msQSC & Mechanically Sealed Qualified Shipping Container \\
\hline NMSS & Nuclear Materials Stabilization and Storage \\
\hline ORNL & Oak Ridge National Laboratory \\
\hline $\mathrm{Pu}$ & Plutonium \\
\hline$R \& D$ & Research and Development \\
\hline RBOF & Receiving Basin for Off-Site Fuel \\
\hline PE\&CD & Projects, Engineering, and Construction Division \\
\hline PSC & Primary Shipping Container \\
\hline ROD & Record of Decision \\
\hline SRS & Savannah River Site \\
\hline SRTC & Savannah River Technology Center \\
\hline $\mathrm{U}$ & Uranium \\
\hline UV & Utility Value \\
\hline WCB & Welded Contamination Barrier \\
\hline WF & Weight Factor \\
\hline WIPP & Waste Isolation Pilot Plant \\
\hline WSRC & Westinghouse Savannah River Company \\
\hline
\end{tabular}

\subsection{REFERENCES}

1. Am/Cm Line Item Project S-5997.

2. Department of Energy Order 430.1, "Life-cycle Asset Management"

3. Westinghouse Savannah River Co., "Key Activities for Successful Execution (KASE) of Projects at Savannah River Site", WSRC-IM-96-167

4. SRS Spent Nuclear Fuel Management Environmental Impact Statement (DOE/EIS-0279D)

5. John C. Tseng, DOE-Acting Director Nuclear Materials Stabilization Task Group, Office of Nuclear Material and facility Stabilization, "Project Management Plan for Environmental Management Nuclear Material Integration", February 10, 1998 Revision O 
WESTINGHOUSE SAVANNAH RIVER COMPANY

Americium/Currium Disposition Life Cycle Planning Study(U)
Document NMP-PLS-980044

Revision 0

April 30, 1998

Page 38 of 159

6. Systems Approach to Functions and Requirements, Instructor Guide, Rev. 0, WSRC-PE\&C Training course TR721B.

7. Americium/Curium Disposition, Scoping Level Alternative Re-evaluation (U), Revision 0, December $11,1997$.

8. Defense Nuclear Facilities Safety Board, Rec:ommendation 94-1 To The Secretary of Energy, May 26, 1994

9. Code of Federal Regulations, Part 10, Chapter 71, Packaging and Transportation of Radioactive Materials.

10. Am-Cm Vitrification Development Program Plan, Rev. 0, Document \# SRC-AMC-97-011, 11/97 


\title{
Appendix A
}

\subsection{APPENDICES}

\subsection{Appendix A: "Americium/Curium (Am/Cm) Disposition Study" Anderson}

Letter, John E. Anderson to J. Frank Jordan, January 30, 1998

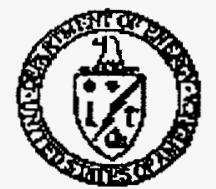

\author{
Department of Energy \\ Sorpannah Fiver Oparationtio Ollace \\ P.O. BoxA \\ Allow, South Carointa 29609
}

FEB + 4

JAN, O

Mr. J. Frank fordata, Vice President and Oenerd Maneger

Nutlear Matetial Stabilinaion and Storage Division

Westinghovese Saveansh River Cocuparay

Ailen, South Curoline 29808

Dear Mr, Jordan:

SUBAET: Americium Curium (Am/Cm) Disposition Stody

Werimghouse Smmonin River Company is requerted to perform addicional stedtee on the disposition of the Amfom solution in P-Crayon Ongoing problems with the vierificution progenge bas lead to questions concerning alternetive appouches to rabilimatian and or disposition of this matterial. The purpose of the study is to provide the Departacent af Enery

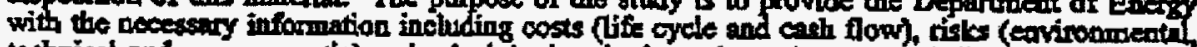

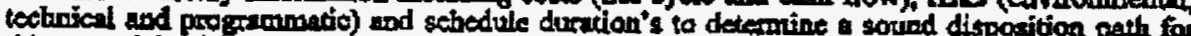
this materinl. Please provide the suldy by April l, 1998, to support ciliced programmetic decisions at both the Bavannsh Rive Site and Oak Ridge National Laboratocy during tho moath of April.

The primery altermetive in this study should include, but not limited 10 , disposition to High Lovel Waste as liquid waste and vitriftention in F-Canyon's Muld Pupose Processing Fucility (MPPF) as either waste or furure use malerith Options within the Dafense Wuste Processing Facility alternative must meet the etument Waste Acoptanes Ctiteria for the cxisting Figh Level Waste frallities usitized. Options within the MPPF glast alternative te not eonstrained by the reed to ditposition other materials via the selocted Am/Cm process. To be a viable option, the phased cupyon trategy's F-Canjon detctivation schedule must oot be delayed or extended to secomrnodnte Am/Con dieposition. All viable options shall includk evatuation of all functions or steps required to disposition the material, such as stabilization, storsege, shipment, etc.

Please contuct me or S. W. MCAlhay of my staff at 952-4802, if you or your staff bave any question.

Sintrely.

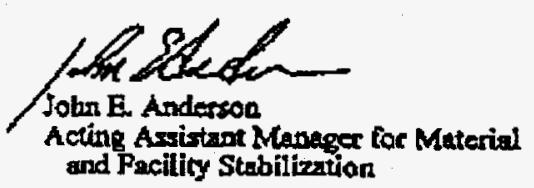

NMSD:SWM:co

Acling Assistant Meneger for Material

UD-98.0038

o: J. W. French WSRC. 703F

S. Evans, WSRC 703-F

M. R Beckmaycr, WSRC, 703F 
9.2. Appendix B: : "Americium/Curium (Am/Cm) Disposition Study (U)" Jordan Letter, J. Frank Jordan to John E. Anderson, February, 1998

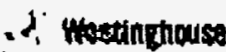

; Saymah RIror Company

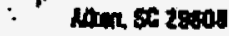

MAR 12
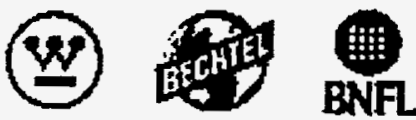

NMS.98-0020

Revention: 2 yrs. IRST: IOAII3

Mr. Jotn E Anderson. Acting Astistant Manager

for Material and Facility Stabilization

Savantuah River Operztions Oftee

U.S. Department of Energy

Aiken, SC 29808

Dear Mr. Anderson:

\section{AMERICTM CURIUM (AN/Cm) OLSPOSITION STUDY AD}

Ref:: Lerter, S.F. Jordsn from J. E. Anderson, "Americium Curium (Ann/Cm) Disposition Sudy", dated "130/98.

Al your reguest, Weatinghouse Saranosh River Company (WSRC) hat initiated additional sturics on the dispositicn of the Americium Curium (Am/Cm) solution presently stored in the F-Canyon fiteility. The ArMCm Project Tean has identified visble options lo successful vitrification of the Am/Cm solution and are actively pursuing development of the flawsheel parameters; the options and the evaluative process for selection of the preferred aption are contained in Revision 1 of the AmKCm Vitrification Development Program Plan that will be presented to the Deparment of Energy and the Defense Nuclear Facilicy Safety Buard. The various options for successful vitrification will be digcussed in the study that frou have requested but not evaluated in the study.

The Nuclear Materials Stabilization and Storage Divition (NMS\&S) of WSRC has commissioned the Project Engineering and Construction Division (PEBCD) to conduct a structured assessment of the life cycke requiremenus for disponitioning vierified Aru/Cm matetials. MMSES personnel will serye as subject matcer experts but the sinxcturod asesesment will be led by PESCD personncl who ofter a level of independence and ure more skilled in the "Engineering A.ppranch". A draft of this study will be corapleted by April 1, 1998, and the study is expected to be completed by April 17. 1998. The focus of this sudy will be to evaluate and cxamine the disposition path for the material; this assumes success of the apgrowed project plan to vitrify. AmPCn in the F.Canyon MulkiPurpose Processing Facility (MPP|.). Costa (life cycle and cash flow), risks (environmental, wehnical, and projgrammatic), and schedule duration will be key parametersoonsiderations used in this assessment. 


\section{Appendix C}

9.3. Appendix C: Core Team for developing the Am/Cm Disposition Life-Cycle Planning Study

William N. Jackson

Westinghouse Savannah River Company

Team Function: Team Lead

Expertise: Management, Systems Engineering, Mechanical Engineering

Overview + Currently WSRC- Project Engineering \& Construction Division-Systems Engineering (SE) Manager, NMSS \& New Missions Support (EA1B9), responsible for supporting projects and new mission areas while managing diverse technical staff and developing SE processes

+ B.S. Mechanical Engineering, continued education in SE processes

+ Ten + years mgt. experience: R\&D, projects and mission develop arenas

+ Ten years experience in plant operations/maintenance, equipment design/development/ fabrication/installation and startup for new and retrofitted radioisotope processing facilities

+ Obtain, integrate \& project annual budgets, \& develop out year projections

Experience: WSRC-PE\&CD - Systems Engineering Mgr. (1/92-Present)

+ Mgr. supporting development of tech. baselines, new mission areas, and projects in support of NMS\&S and Site Strategic Planning Divisions

+ Supporting development of site wide systems engineering processes

+ Currently assisting development of DOE material disposition path process

+ Assisted Development of FDD/SDD process and support tools

+ Developed / applied "Strategic Planning Process"

+ Interfaced with DOE-HQ, INEL, ORNL, LANL, LLNL, and Hanford to: develop various reports/strategies in support of complex wide material disposition programs and new mission areas, required funding and AOP budget projections/revisions/tracking

+ Participated in TWRS systems capability assessment at Hanford

\section{WSRC-SRTC Research Engineering Mgr. (4/89-1/92)}

+ Established regularly scheduled project review meetings to define researchers' requirements and monitor staff progress on projects/tasks

+ Participated in ORNL "Lithium Process Replacement Project" Readiness Review

+ Provided tech. consultation on the SRS "235-F Neptunium Line Project"

+ Participated in two TQFRs (HB-Line \& SRTCs Laboratory Services Section)

\section{E.I. du Pont de Nemours \& Co. Process Enqineer $(6 / 77-4 / 89)$}

+ Toured, attended meetings and participated in various equipment/facility design/development project efforts at LLNL, ORNL, LANL, INEL, ORNL, Hanford, Rocky Flats and England's Selafield \& Aldermaston sites .

+ Supervised test facility and design personnel, focus on Tritium support areas

+ Reviewed and developed cost estimates, requirements, scopes of work, and designs for nuclear material production and shipping equipment/casks (Gloveboxes, slab tanks, calciners, agitators, valves, Pumps, incinerators, transfer devices, etc.)

+ From 1982 to 1989, located in Wilmington, DE, supporting SRS projects

+ Founding director of "American Glovebox Society", currently 300 members 


\section{Appendix C \\ Westinghouse Savannah River Company}

Team Function: Core Team Member

Expertise: $\quad$ Actinide Separations, Radiochemistry, Life-Cycle Analysis

Overview + Currently WSRC Principal Technical Advisor, Strategic Planning and Integration Department, providing economic analyses to the Spent Fuel Storage Division for decision processes for management of SRS aluminum clad spent nuclear fuel, and providing cost analysis expertise to the Nuclear Material Integration Task Team

+ B.Sc. in Chemistry, U.S. Air Force Academy; M.Sc. in Chemistry (AEC fellow), University of California, Berkeley; M.E. Ch.E, University of Idaho

+25 years experience in nuclear related analysis and operations

+ Developed Fluorinel flowsheet calculation and process control methodology (for dissolution of spent Naval fuel) from bench experiments to hot plant startup

+ Participated in seven national task teams related to Nuclear Weapons Complex issues

Experience: $\quad$ WSRC-SPID Principal Technical Advisor (12/92 to Present)

+ Developed life-cycle cost study to support a study of the nonproliferation impacts of spent nuclear fuel reprocessing and the SRS SNF EIS

+ Provided life-cycle cost analys s and technical expertise to the SRS spent nuclear fuel decision process and evaluatic of privatization opportunities

+ Developed studies on SNF life-cycle costs, spent fuel storage, plutonium discard limit implementation, nuclear materials disposition and complex-wide nuclear material disposition issues.

Nuclear Engineer, U.S. DOE-SR (3/87 -12/92)

+ DOE Nuclear Materials Managyer.

+ Coordinated and reviewed technical planning studies

+ Participated in task forces on capital asset management, reconfiguration siting (lead for transportation), and plutonium discard limits.

\section{Senior Scientist, Idaho Chem.Processing Plant (3/77-3/87)}

+ Developed process control method and Fluorinel process flowsheet and reagent addition computer programs (George Westinghouse bronze award 1985).

+ Modeled process dissolution criticality permitting deletion of a major system, and substantial waste reduction.

+ Operated Fluorinel Dissolution Pilot Plant. Startup engineer for Fluorinel

+ Lead for NRC funded experimental program to evaluate post-accident (nuclear) radioiodine sampling and measurement equipment.

+ Performed studies of actinide and fission product extraction coefficients for dihexyl, N,N, diethyl carbamyl methylene phosphonate

Analytical Engineer, United T"echnologies (3/74-3/77)

+ Analyzed pilot plant scale steain reformer data for fuel cell hydrogen generation

Nuclear Res. Off., 1155 Tech.Ops Sqdn, USAF, (1/70-1/74)

+ Performed tracer and carrier-kiased radiochemical analysis. 


\section{Appendix C \\ Steven R. Nester
Westinghouse Savannah River Company}

Team Function: Core Team Member

Expertise: $\quad$ Electrical Engineering, Systems Engineering

Overview Currently Senior Engineer with Systems Engineering, responsible for leading pre-conceptual project development, engineering analysis, and feasibility studies.

B.S. Electrical Engineering from the University of Illinois at Chicago

Eight years engineering and project leadership experience at DOE's Savannah River Site

\section{Experience: Systems Engineer - Nuclear Materials January 13, 1998 to present}

Currently performing studies for disposition paths for various nuclear materials.

IPI Coordinator - Tritium NNR August 1, 1997 to January 12, 1998

Performed the Installed Process Instrumentation (IPI) coordinator function for NNR-Tritium.

Lead Engineer - HLW GPP/CE Projects May 1, 1996 to Auqust 1, 1997

HLW GPP/CE Lead for Systems Engineering. Duties included coordinating all Systems engineers on all HLW GPP/CE projects for facilities including H-Area Tank Farm, ETF, and ITP.

Responsible for the following:

- developing, completing, issuing, and revising of all Task Requirement \& Criteria Documents, Functional Acceptance Criteria, and some Plant Modification Travelers.

- planning and securing work for Systems Engineering, along with resources

- ensuring Systems Engineering satisfies financial and scheduling commitments with the HLW Project Management and Project Controls organizations.

- working with Design Authority personnel, including cognizant engineers in order to develop and ensure the quality and accuracy of technical baseline documents generated by Systems Engineering.

- initiating \& tracking Activity Codes allotted for Systems Engineering Support.

- initiating all HAD Reviews of HLW projects.

- ensuring completion of technical reviews for all projects.

\section{Systems Engineer February 5, 1990 to May 1, 1996}

\section{DWPF and Late Wash Support}

Provided design and cognizant-type support to facilitate startup and operation of DWPF and Late Wash. Deliverables included: Redundant I/O analysis of DWPF drawings, close-out of C-Punchlist items, generation and implementation of DCF's, walkdown packages, preventative maintenance plans.

\section{Reactors and Separations}

Developed process and instrument guides for Separations shift technical engineers. (ex. FB Line Mechanical Line)

Developed functional performance requirements and design criteria for projects throughout the Savannah River Site; K Reactor, Separations, RBOF facility, F and H Tank.Farms, ITP Facility, ETF Facility.

Led effort to apply CAPTOR software to breaker / fuse coordination studies for Reactor Restart in February 1990. 
WESTINGHOUSE SAVANNAH RIVER COMPANY

Americium/Curium Disposition Life Cycle Planning Stcdy(U)
Document: NMP-PLS-980044

Revision 0

April 30, 1998

Page 44 of 159

\section{Appendix C \\ Reuben Rainisch
Westinghouse Savannah River Company}

Team Function: Core Team Member

Expertise: $\quad$ Nuclear Engineering, Mechanical Engineering, Systems Engineering
Overview + Currently WSRC - Project Engineering \& Construction Division-Systems Engineering (SE) Principal Engineer (1989 to Preserit)
+ B.S. Marine Engineering, University of Michigan, Ann Arbor, Michigan
+ M.S. Nuclear Engineering, University of Michigan, Ann Arbor, Michigan
+ Nuclear Engineer, University of Michigan, Ann Arbor, Michigan (This is an advanced degree that included 30 credit hours of course work beyond the Master of Science degree)
+ Twenty Five years of nuclear engineering experience: Radiological And Shielding Analysis, Conceptual Design Of Non-Reactor Nuclear Facilities, TMI, Unit 2 Recovery Effort, Decommissioning Projects, and Erigineering In Association With The Design Of Nuclear Power Plants.

Experience: $\quad$ WSRC-PE\&CD - Systems Engineering. Principal Engineer. (10/89 to Present)

+ Radiological Engineering Assignment (Safety Engineering Dept.): Perform Shielding Analysis And Source Terms Analysis, Radiological Design Criteria, Radiological Design In Association With The Immobilization Of Plutonium Materials

+ Conceptual Design Of Non-Reactor Nuclear Facilities: Conducting Engineering Studies, And Preparing Design Criteria. Projects included Interim Storage of Spent Nuclear Fuel and Storage of Vitrified Waste

+ Decommissioning Of Nuclear Facilities: Preparing Facility Characterization And Scope Of Work Reports

+ SRTC Assignment: Preparing Hazard Assessment Documents (HADs), and Coordination of Hazards Assessment Efforts

+ Regulatory Compliance Assignmerit: Identification of Standards that apply to DOE facilities in the functional area of nuclear safety

: $\quad$ Burns and Roe, Inc., Principal Nuclear Engineer (1976 to 1989)

+ Three Mile Island, Unit 2 Recovery Effort Assignment (Middletown Pennsylvania 1983 to 1989): Acquisition, interpretation and analysis of data relating to conditions inside the damaged reactor vessel. Characterization of the extent of reactor and core damage. Shielding analysis.

+ Major contributor to a DOE project involving feasibility studies for using the Western New York Nuclear Service Center for solidifying the high level nuclear waste stored at the site (West

- Valley Demonstration Project)

+ Major contributor to the Shippingpcrt Atomic Power Station Decommissioning Project. Assessment of one piece removal of the reactor vessel/internals.

+ Nuclear Engineering in association with the design of light water reactors (PWR Type). Design of reactor balance of plant, design of containment system, shielding analysis, and Site Suitability Source Term Analysis.

\section{Combustion Engineering, Senior Physicist \& Senior NSSS Engineer (1972 to1976)}

+ Study of core power performance aspects, and the interrelationship between the operating modes and operating margins. Responsibility for the development of an algorithm designed to provide core operating margin information. Supported the design of CE System 80 Nuclear Steam Supply System. 


\section{Appendix C \\ Paul Stutts \\ Westinghouse Savannah River Company}

Team Function: Core Team Member

Expertise:

Facility Acceptance, Start Up, Acceptance and Operations. B.S Physics, University of

Tenn. Chattanooga.

Overview

- Currently WSRC- Project Engineering \& Construction Division-Systems Engineering (SE), Principal Engineer NMSS \& New Missions Support, supporting projects and new mission areas.

- Seven years in the Projects Engineering and Construction Division, Systems Engineering, performing Lead functions in project transition and facility acceptance tasks.

- Twenty years in commercial power, including six years in nuclear facility management positions. Performed duties in Technical Support (System Engineering) and task management, Preventive Maintenance program management, QA oversight/monitoring of Plant (Systems) Engineering activities up to and including recommending operational readiness, management of overall plant operational activities (i.e. all systems operations, maintenance, and testing activities), and consultant to nuclear utilities in the areas of Configuration Management and Baseline Engineering, Startup, and Maintenance Program Development.

Experience: July 1990to Present - WSRC Savannah River Company

Performed the following Lead Engineer functions for Systems Engineering:

- Replacement High Level Waste Evaporator Project including development of Project Turnover Plan, Functional Acceptance Criteria document and Test Plans

- Consolidated Incineration Facility SE Team tasks

- Chairman of the Systems Engineering Functional Acceptance Criteria committee

- Project Team coordination, development, and implementation of Title III Acceptance program.

- Coordination, development, and issue of Project Turnover Plans for Analytical Laboratory projects

- Drafting the first Project Verifications and Acceptance procedure for the DWP Facility.

January 1970 to June 1989:

- Bectel/IMC International, (Contract) Browns Ferry Nuclear Plant, Decatur Al. Baseline Design Engineer. Performed operability reviews, safety evaluations, and developed special post modification system performance tests to verify design basis.

- Houston Power and Light/llini Tech., South Texas Project Nuclear Generating Station, Bay City, Tx.. Work Control Coordinator. Point of contact for priority variations and scheduling adjustments according to critical path during power ascension testing of Unit 2 and normal operations of Unit 1.

- Browns Ferry Nuclear Plant, TVA, Quality Assurance. Responsible for monitoring system engineering performance when evaluating systems for operational readiness.

- Bellefonte Nuclear Plant, TVA, Hollywood, Al. Manager responsible for overall administration/implementation of the preventive maintenance program and coordination of interfacing groups including-Maintenance and Engineering, Quality Control Engineering, Division of Nuclear Construction, and Technical Support Services. Assistant to the Technical Support (Systems Engineering) Manager for task management and interfacing engineers with the Nuclear Steam Supply System (NSSS) Vendor, System Engineers, Construction Management, and Plant Maintenance Management. As Shift Operations Manager was responsible for operational supervision and coordination of all plant activities (i.e. all systems operations, maintenance, and testing).

- Paradise Steam Plant, TVA, Drakesboro, Ky. Directed the operation of a once-through supercritical, fossil fueled, 1100 megawatt electrical power generating unit. Supervised unit startup, operation and shutdown. Interfaced and coordinated work with maintenance sections to ensure maximum unit availability. Administered upgrade accreditation exams for operations personnel, assisted in instruction of student classes, and acted as Training Representative. 
WESTINGHOUSE SAVANNAH RIVER COMPANY

Americium/Curium Disposition Life Cycle Planning Stıdy(U)
Document: NMP-PLS-980044

Revision 0

April 30, 1998

Page 46 of 159

\section{Appendix D}

\subsection{Appendix D: Team Domain Experts for Am/Cm Disposition Life-Cycle Planning Study}

1. Chuck Alexander

Oak Ridge National Laboratory

Mr. Alexander received his Master of Science Degree in Nuclear Engineering from North Carolina State University. He has worked at the Oak Ridge National Laboratory from October 1976 to the present. During this time the focus of Mr. Alexander's responsibilities has been on waste partitioning and transmutation, fuel cycle analyses, heavy element production and recovery, integral cross section measurements, special isotope projects, gereral isotope production and recovery, and the ORNL Mark 42 Program.

2. T. Andes, Fuel Handling Engineering, Westinghouse Savannah River Co

3. Spencer J. Brady, Principal Environmental Engineer Westinghouse Savannah River Co. - Nuclear Materials Stabilization \& Storage Division

Mr. Brady is a registered Professional Engineer with 19 years progressive experience in environmental project management, engineering and marketing in the nuclear, fossil fuel and waste incineration industries. His academic credentials include an MS in Civil Engineering, a BS in Geology, both from the University of Pittsburgh, along with graduate studies in Management and Finance at Carnegie-Mellon University. Mr. Brady began working at SRS in 1991 as a Project Manager on the Consolidated Incineration Facility and is currently responsible for managing the environmental permitting effort for the Actinide Packaging and Storage Facility. Mr. Brady is a former officer in the Air and Waste Management Association and is certified as a Registered Environmental Manager by the National Registry of Environmental Professionals. Prior to joining WSRC, Mr. Brady held positions of increasing responsibility at Westinghouse Electric Corp., Consolidation Coal Company and Consolidated Natural Gas Corporation.

4. S. Brooks, Westinghouse Savannah River Co. - SFSE

5. Emory D. Collins, Senior Technical Advisor, Oak Ridge National Laboratory- Chemical Technology Division

Mr. Collins is a chemical engineer with a B.S. ChE from Auburn University and graduate studies at the University of Tennessee. He is a member of the American Institute of Chemical Engineers, Sigma Xi, a former member of the American Nuclear Society, and a Professional Engineer in the State of Tennessee. Mr. Collins' career at ORNL began in 1965 in the Chemical Technology Division where he has served in various technical and technical management roles, most recently as Isotope Technology Program Manager and Section Head. Mr. Collins has been involved in numerous technical projects in the isotope production and radiochemical engineering fields.

6. R. Gromada, Westinghouse Savannah River Co. -EFS/P\&J

7. M. Hackney

Westinghouse Savannah River Co., Operations Support Lead, Receiving Basin for Offsite Fuel (RBOF), Spent Fuel Storage Division 


\section{Appendix D}

Mr. Hackney is a mechanical engineer with a B.S.M.E. from West Virginia University. His career began in 1983 at the Savannah River Site where he has served in various management, engineering and supervisory roles.

8. Mohan Jerath

Westinghouse Savannah River Co., NMS\&S-Engineering

Mr. Mohan Jerath has a B.S. degree in Mechanical Engineering and M.S. from University of Wisconsin. Mr. Jerath's career at SRS started in 1985 and has served in various technical and management positions in NMS\&S. Prior to working at SRS, he had worked as a consulting engineer for 12 years for commercial, public and DOD installations in the Southeast. He has considerable experience in construction oversight, design, maintenance, startup and testing of various facilities and projects in Separations Engineering. He is a registered professional engineer in the State of Georgia. He has won several awards on site for using innovative methods for solving problems.

9. R. H. Jones, Trade Studies

Westinghouse Savannah River Co. - Nuclear Materials Stabilization \& Storage Division

10. John E. Marra, Program Manager, Stabilization Process Development

Westinghouse Savannah River Co. - Savannah River Technology Center

Dr. Marra has a B.S. degree in Ceramic Science and a B.A. degree in Chemistry from the New York State College of Ceramics at Alfred University. He also holds a Ph.D. in Ceramic Engineering from The Ohio State University. Dr. Marra's career at SRS began in 1987 and he has served in various technical and management positions within the Savannah River Technology Center and the High Level Waste Management Division. He has considerable experience in the treatment of actinide materials. Dr. Marra is a Fellow of The American Ceramic Society and currently serves on the Board of Trustees and Executive Committee of the Society. He is the author of more than 30 technical papers.

11. William H. Martin, Am-Cm Design Authority Manager

Westinghouse Savannah River Co. - Nuclear Materials Stabilization \& Storage Division

Defense Waste Vitrification Development, Naval Fuels Analytical Support \& Processing, Mr. Martin is a chemist/manager with a B.S. Chemistry from Auburn University. He is a member of the American Chemical Society (ACS) and the National Management Association (NMA) where he is a Certified Manager (CM) through the Institute of Certified Professional Managers (ICPM). Mr. Martin's career began at the SRS in 1969 in the Analytical Laboratories Department and progressed through the Separations, Naval Fuels, High Level Waste Management, Savanah River Laboratory, and now with the Nuclear Materials Stabilization and Storage Division. He has held various technical and managerial roles involving the original Californium MPPF Processing, the Americium-241 MPPF Processing, PUREX Analytical Support, Highly Enriched Uranium Processing, and High Level Waste Storage \& Treatment culminating with his most recent assignment as Design Authority for the Am-Cm Stabilization Project.

12. Erich Opperman, Manager, Packaging and Transportation Group Westinghouse Savannah River Co. - Savannah River Technology Center

Responsible for design, testing, and certification of Type B transportation packaging since 1989. Mr Opperman has BS degrees in Physics and Mathematics, and an MS in Nuclear Engineering and has been actively involved in transportation packaging work for over 12 years. Mr Opperman has chaired ANS sessions on packaging, and has been selected to participate in numerous DOE appointed committees investigating radioactive material packaging design issues. Currently $\mathrm{Mr}$ Oppermans group 
WESTINGHOUSE SAVANNAH RIVER COMPANY

Americium/Cyrium Disposition Life Cycle Planning Study(U)
Document: NMP-PLS-980044

Revision 0

April 30, 1998

Page 48 of 159

\section{Appendix D}

is directly responsible for 5 DOE HQ Certified Type B packaging designs, 1 DOE AL Weapons packaging design, and leads the Commercial Light Water Reactor (CLWR) Transportation Program.

13. Donald R. Schilling

Idaho National Engineering Laboratory

Donald R. Schilling is an Engineering Fellow with Lockhead Martin Idaho Technologies at INEL. Mr. Schilling has a BS in EE from Drexel University. He is a member of the NMI Project Team providing systems engineering for the TRU material Team. He has provided SE for the Plutonium Focus Area (PFA), he was a principle author of the PFA Technology Summary (Rainbow Book) and he wrote the system requirements section for the NMSTG's, Project 94-1. Don teaches SE at the INEEL, has 20 years experience as a systems analyst, project leader, section head in the energy and aerospace industry, and has developed courses for ORNL and Hanford.

14. J. Thomas

Westinghouse Savannah River Co. - Nuclear Materials Stabilization \& Storage Division

15. Bob Wham

Oak Ridge National Laboratory 


\section{Appendix E}

\subsection{Appendix E: Reviewers for Am/Cm Disposition Life-Cycle Planning Study}

N. E. Barnett, Mgr.

G. W. Becker

J. S. Bellamy

J. Bigelow

A. W. Bower III, Mgr.

D. E. Buxton

F. Cadek, Mgr.

T. G. Campbell

J. D. Cohen, Mgr.

E. Collins

J. E. Dickenson

J. P. Duane, Mgr.

R. A. Eubanks

J. S. Evans, Mgr.

J.W. French

M. Ferreu

W. N. Jackson

G. V. Klipa

J. Knauer

W. H. Martin

R. S. Matthews

S. W. Mcalhany

V. C. Minardi, Mgr.

A. P. Mock, Mgr.

E. Moore

L. M. Papouchado, Mgr.

J. Rushton

T. F. Severynse

R. W. Williams, Mgr.
WSRC: NMSS: Engineering \& Technical Support (SE2230)

WSRC: Strategic Programs \& Planning Department (AA1000)

WSRC: NMSS: Engineering \& Technical Support (SE2230)

ORNL

WSRC: NMSS/Project Integration (SL1000)

WSRC: NMSS/F Canyon Facility (SG1200)

WSRC: PECD/Systems Engineering (EA1B0)

WSRC: NMSS/Engineering \& Technical Support (SE2230)

WSRC: SRTC/Engineered Equipment \& Systems (L8000)

ORNL

WSRC: NMSS/Engineering \& Technical Support (SN0000)

WSRC: NMSS/Trade Studies (SP1700)

WSRC: NMSS/H Canyon Systems Engineering (SE1810)

WSRC: NMSS/Separations Engineering (SE1000)

WSRC: NMSS/Engineering \& Technical Support (SNO000)

ORNL

WSRC: PECD/Systems Engineering (EA1B9)

DOE-SR: Program Planning \& Integration (5221100000)

ORNL

WSRC: NMSS/Programs: AM/CM (SE1100)

WSRC: NMSS/Trade Studies (SP1700)

DOE-SR: Materials \& Facility Stabilization $(5221000000)$

WSRC: NMSS/NMP Programs (SP1000)

WSRC: NMSS/F Canyon EngineeringlArea Support (SE1600)

WSRC: Strategic Programs \& Planning Department (AA1100)

WSRC: SRTCNaste Mgmt. \& Env. Technology (L3000)

ORNL

WSRC: NMSS/Trade Studies (SP1700)

WSRC: NMSS/Project Integration Actinide Verification (SL1200) 
Appendix F

\subsection{Appendix F: Am-Cm Vitrification Development Program Plan Overview}

The Savannah River Technology Center (SFRTC) has been working to develop a physical system to vitrify a nitric acid surrogate solution representative of material awaiting processing in F-Canyon. Details of the test program are provided in the Am-Cm Vitrification Development Program Plan (reference document, SRT-AMC-97-0111). The project to date has tested, evaluated, and redesigned the original "bushing" melter concept of 1994 through several iterations. "Bushing" melters designated as Melter 1, Melter 2, Melter 2A and Melter 2B have been installed and tested at the TNX Am-Cm Pilot Facility in 672-T. The Cylindrical Induction Melter (CIM) is the newest design to be evaluated in the Am-Cm development series.

The Cylindrical Induction Melter system instialled at TNX is a pilot demonstration version of a more robust and remotely operable system to be installed in the Multipurpose Processing Facility (MPPF). The CIM system is located in 672-T. It consists of an inductively heated Pt-Rh containment vessel, two induction heating systems and power supplies, a control system, a chiller, and a simple off-gas filtering system. The difference between the CIM arid previously tested Am-Cm systems is this Pt-Rh melter vessel is heated by induction and the previous bushing melters were direct fired.

An oxalate precipitate produced from the Am-Cm solution will be batched to the melter containing a carefully measured amount of glass forming frit . Volatilization products and other offgases will be swept into a semi-circular slotted hood positioned above the top of the CIM vessel, then drawn through a moisture separator and high efficiency particulate air (HEPA) filter before being exhausted to the stack. The glass flows from the bottom of the Pt-Rh vessel by gravity through an inductively heated PtRh drain tube into a steel canister. A separate water chiller provides cooling water to the induction coils and heat stations to prevent overheating.

While the batch process using the CIM technology is the baseline process and has shown good results in initial tests, additional vitrification options are being investigated. The primary goal of this work is to evaluate the feasibility of performing 'in-can' vitrification of the Am-Cm material. In the 'in-can' concept, the material is processed in the containment vessel, eliminating the need for pouring. Low temperature glass compositions are being investigated ir order to decrease the cost of the vessel (i.e., if melting temperatures can be reduced to $\angle 1150 \mathrm{C}$, it may be possible to utilize a vessel constructed of Inconel690 as opposed to the use of Pt-Rh using the current glass formulations). One of the concepts being investigated will use an oxalate precipitate feed and a Frit 165 (a well characterized DWPF frit) glass composition. A second alternative being investigated involves a process developed by the Russians using silica gel to absorb the $\mathrm{Am}-\mathrm{Cm}$ material. In this process, the SiO2 gel with the absorbed material is dried and/or calcined in a rotary calciner. The resultant calcined product could then be incorporated into a glass composition. These concepts will provide alternatives should the difficulty be encountered with the current baseline process. 


\section{Appendix G}

\subsection{Appendix G - Off-Site Transportation -- Packaging Considerations}

\section{INTRODUCTION}

All of the Am/Cm Disposition Alternatives ultimately include off-site shipment of immobilized materials to ORNL, with the exception of one option that dispositions Tank 17.1 solution to glass and then to the National Repository. This Appendix includes: (a) An assessment of key regulatory requirements that the shipments must satisfy; (b) Identification of actions needed to satisfy key regulatory requirements; and; (c) some planning of the off-site shipment campaign.

\section{ASSUMPTIONS:}

1. The Am/Cm glass form placed in a canister in combination with a welded steel container should enable approval for shipping the Am/Cm in a single containment cask (E. Opperman, SRTC Packaging) (See report Section 6.7.4).

2. If double containment is required for shipping, several options exist. (See Appendix $H$, Section 9.8.2). For the Base Case, Alternative 1, and Alternative 2, it is assumed that the primary shipping containers (CwP-1 or msQSC) can be qualified and licensed as forming the primary containment around the $\mathrm{Am} / \mathrm{Cm}$ glass canisters. The qualification of the primary containment vessels, and subsequent evaluations of the shipping package (using a cask designed and approved for single confinement) would enable the project to ship the Am/Cm materials off-site.

\section{BASIS}

\section{Geometry}

1. The inner cavity of the NLI cask is $178^{\prime \prime}$ Long $\times 12.63^{\prime \prime}$ ID (Reference 1 ). It is assumed that other spent fuel type casks will have similar cavities. Therefore, existing casks will be capable of physically holding the material. A loading basket will have to be designed and built for holding the canisters in the cavity.

2. The canisters within the primary shipping containers (CWP-1 or msQSC) will be loaded into the cask in a single column (axial configuration). The NLI cask cavity will be able to accommodate eight (8) canisters. The eight (8) packaged canisters will take up approx. 136 inches. This will leave 42 inches for additional shielding that may be required at the ends, or near the cask opening.

3. The column loading in the cask will satisfy the ORNL can unloading method.

\section{Shielding (Dose Rates)}

1. Shipping the Am/Cm will require casks that include both neutron and gamma shields. The NLI cask incorporates both neutron and gamma shields. The shielding configuration of the NLI cask includes: depleted uranium, lead, and borated water.

2. Scooping shielding calculations performed for the NLI cask (reported in Reference 2) show that if the diameter of the glass within the canister does not exceed 2 inches, the 2 meter (distance from cask surface) dose rate requirement of less than $10 \mathrm{mrem} /$ hour is met.

\section{Containment:}

1. Regulatory requirements in 10CFR71.63 call for a second containment for shipments containing more than $20 \mathrm{Ci}$ of plutonium. Assuming eight (8) canisters per shipment, the $20 \mathrm{Ci}$ limit will probably be exceeded. Even six canisters would probably exceed the $20 \mathrm{Ci}$ limit. But, for shipments of $\mathrm{Am} / \mathrm{Cm}$ in glass form it is still not clear if the second container would need to undergo the certification required for double containment. The SRS packaging group is evaluating this. 


\section{Appendix G}

2. Based on plutonium measurements of Tank 17.1 contents performed on $2 / 93$, the tank holds 3,090 Curies of plutonium (Ref. 3). Pretreatment 0 : the tank contents will remove a significant portion of the plutonium. Up to $80 \%$ (Ref. 4 \& 5) of the plulonium may be removed during pretreatment. However, the exact plutonium retention in the glass is still undergoing review, and not yet known. There will also be some in-growth of Pu-240 due to decay of Crn-244. This additional activity is estimated at 170 Curies (by 2/02). The activity per glass canister also depends on the number of canisters that will be produced. It is estimated that the Am/Cm vitrification effort will result in the production of between 150 to 200 glass canisters (Ref. 1). Preliminary estimates based on $30 \%$ plutonium retention show that the activity per canister may range from 4.7 to $6.5 \mathrm{Ci} / \mathrm{can}$. This implies that including more than 3 to 4 glass canisters per shipment may result in the plutonium activity exceeding the 20 Curies threshold.

3. The current plan is to ship the Am/Cm materials to ORNL in single containment casks. Spent fuel type casks (like the NLI cask) are single containment casks. It is further planned to include up to eight (8) glass canisters in each off-site shipment. Based on geometry considerations this can be achieved. If shipments incorporating eight (8) canisters exceed the 20 Curies/shipment plutonium threshold, the plan to ship in a single containment cask may be defended by argument presented under Assumptions (Item 1). If not, another containment level will be required and is shown in several options. The entire shipping package would then require qualification.

\section{Thermal Limits}

The overall heat load of the contents of Tank 17.1 is estimated at 8,000 watt (Ref. 1, H. Martin). This implies that the heat load per canister will range from 40 watt/can (for 200 canisters) to 53 watt/can (for 150 canisters). The maximum decay heat load for a shipment of eight (8) glass canisters is estimated at $\sim 420$ watts. A survey of a number of spent fuel casks shows that the dissipation of 420 watts of decay heat can be readily accommodated and that decay heat is not an issue. The decay heat limit of the NLI cask is 750 watts (E. Apperson, SRTC Packaging).

\section{COST:}

1. The typical leasing cost for a cask is $\$ 57,000$ for a 10 day period. There is a charge of $\$ 4,000 /$ day for increasing the lease time beyond 10 days.

2. The cask lease fee for 12 shipments per year is approximately $\$ 500,000$.

3. The cost for trucking the loaded cask to ORNL and the empty cask back to SRS is $\$ 2,400$ (round trip).

4. The cost for buying a cask is approximately $\$ 3$ Million.

5. The cost for re-qualifying a cask, i.e. from single containment to double containment would be $\sim \$ 1.5$ Million. (Assumes cost of container and it's diesign are zero, i.e. complete)

\section{REFERENCES:}

1. US Nuclear Regulatory Commission, Certificate of Compliance for Radioactive Material Packages, Certificate Number 9010. This Document provides a description of the NLI Cask.

2. WSRC, Inter-Office Memorandum (All-In-1) from Robert L. Frost to Richard J. Gromada, Titled: Am/Cm, dated $12 / 19 / 95$. This memorandum reports the results of a $1-D$ scoping shielding analysis for $A m / C m$ packaging.

3. WSRC Document \#NMP-PRG-961887, titled: Material Control and Accountability Analysis for F-Canyon Am/Cm Process, by T. G. Clark, dated 11/20/96.

4. WSRC Document \#WSRC-TR-96-0228-TL, titled: Material Balance Calculations for Am/Cm Pretreatment Flowsheet. By: F. G. Smith, III, dated 7/29/96.

5. Personal communications R. Rainisch (PE\&CD, SE) and Herb Martin (NMSS), March 1998 


\section{Appendix $\mathrm{H}$}

9.8. Appendix H: Representative Figures.

9.8.1. Legend

Canister

Container with Pintle (CwP) [note: pintle used for lifting]

CwP-1 = qualified container per shipping requirements, CwP-2 $=$ not a qualified container per shipping requirements, only provides contamination control

CwP-3 = a CwP-2, with crimped tube(s) used to remove water and add helium

Mechanical Sealed Qualified Shipping Container (msQSC)

Shipping Cask 
WESTINGHOUSE SAVANNAH RIVER COMPANY

Americium/Curium Disposition Life Cycle Planning Study(U)
Document: NMP-PLS-980044

Revision 0

April 30, 1998

Page 54 of 159

\section{Appendix $\mathrm{H}$}

\subsubsection{Packaging Figures}

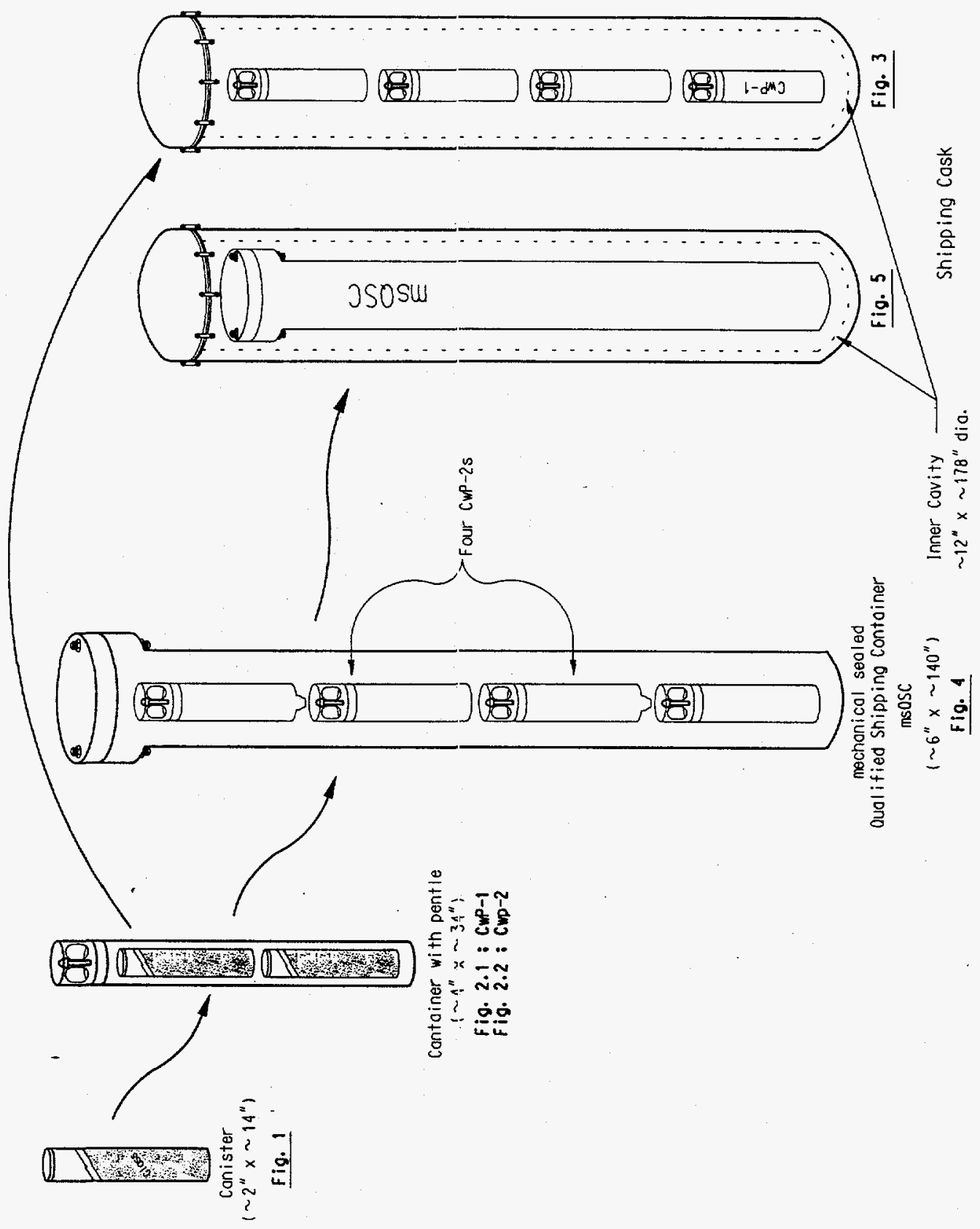


WESTINGHOUSE SAVANNAH RIVER COMPANY

Americium/Curium Disposition Life Cycle Planning Study(U)
Document: NMP-PLS-980044

Revision 0

April 30, 1998

Page 55 of 159

\section{Appendix $\mathrm{H}$}

\subsubsection{Mark 18 Packaging Figures}

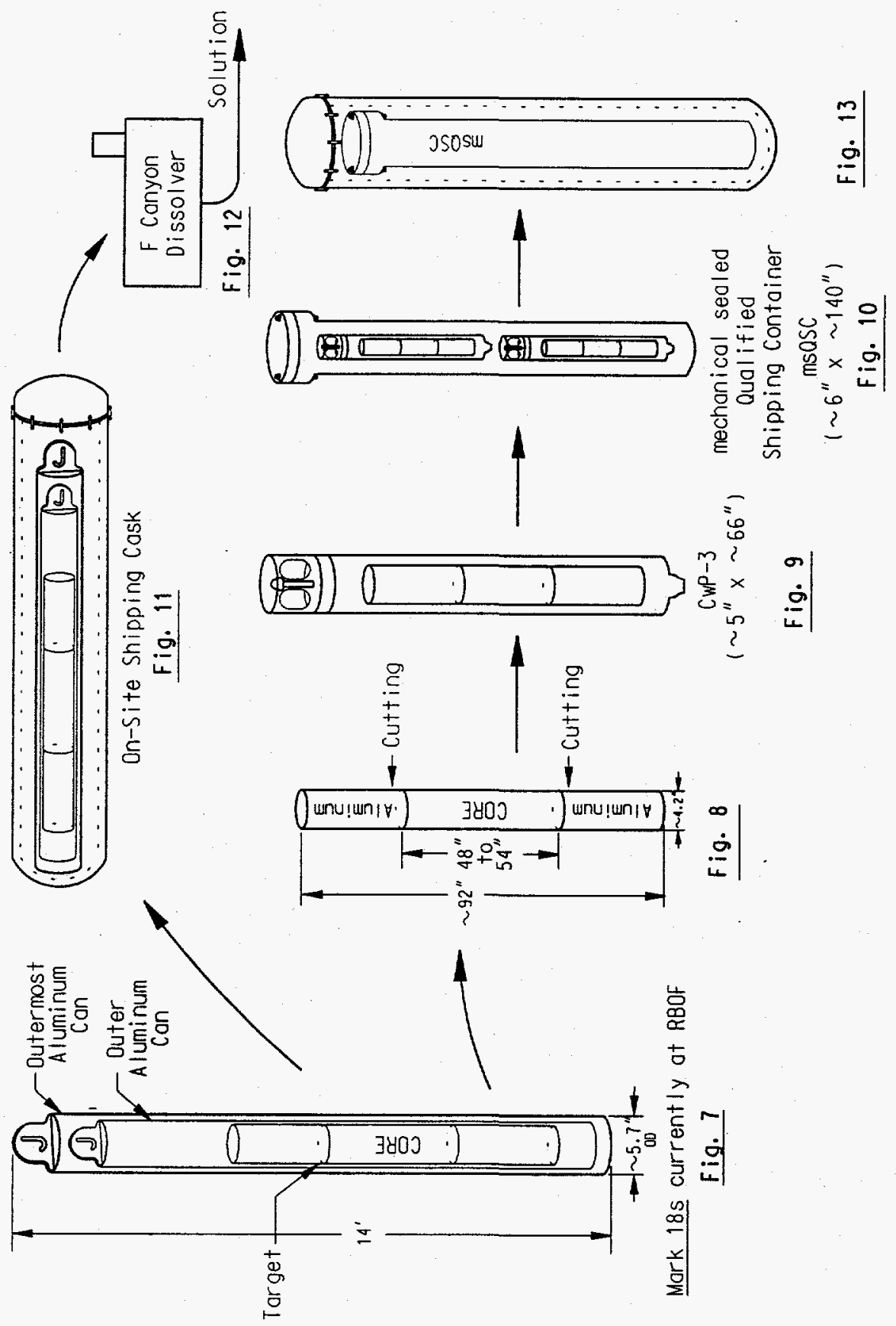


Am/Cm Tank 17.1 Solution Disposition Alternatives

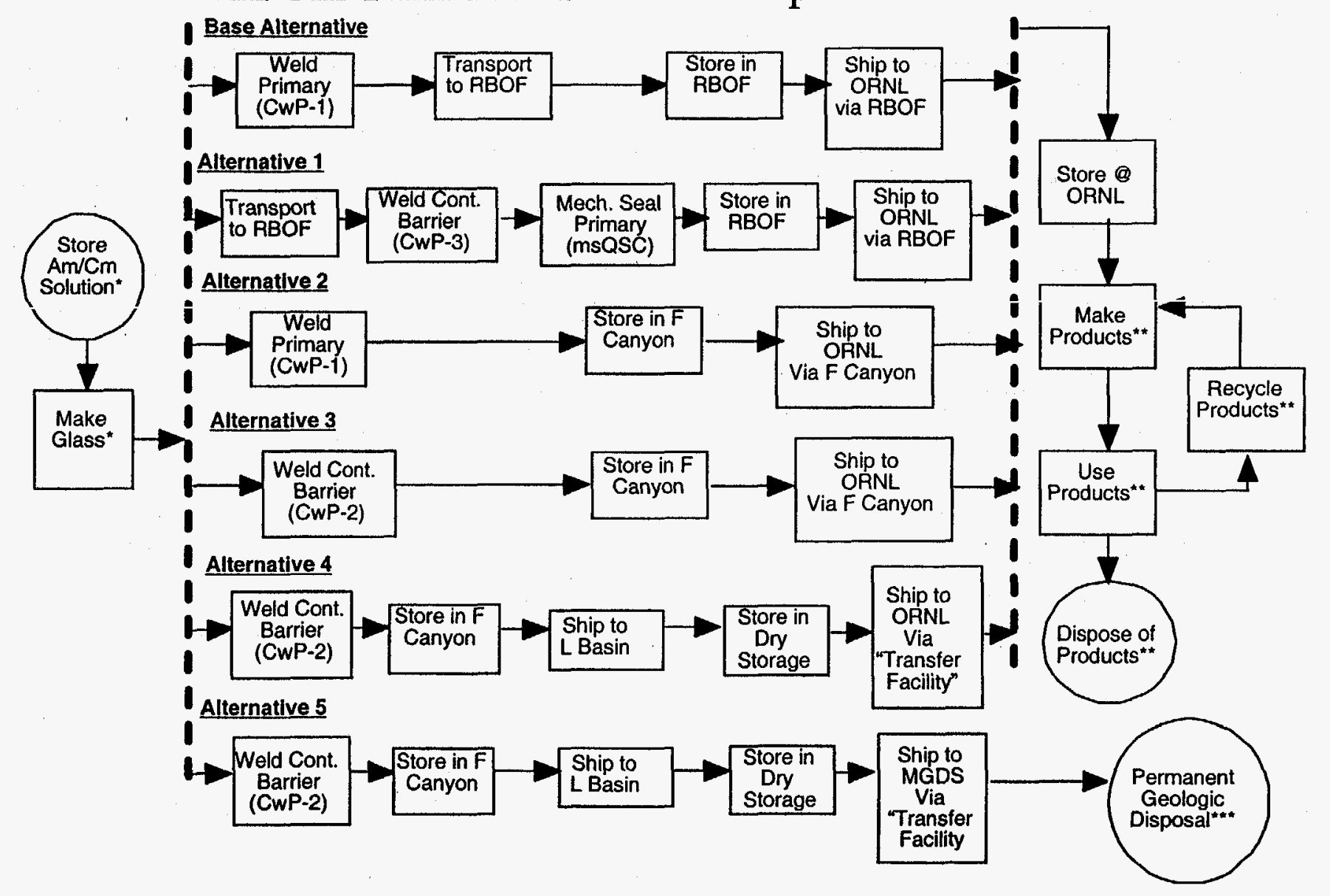




\section{Am/Cm Mk-18 Disposition Alternatives}

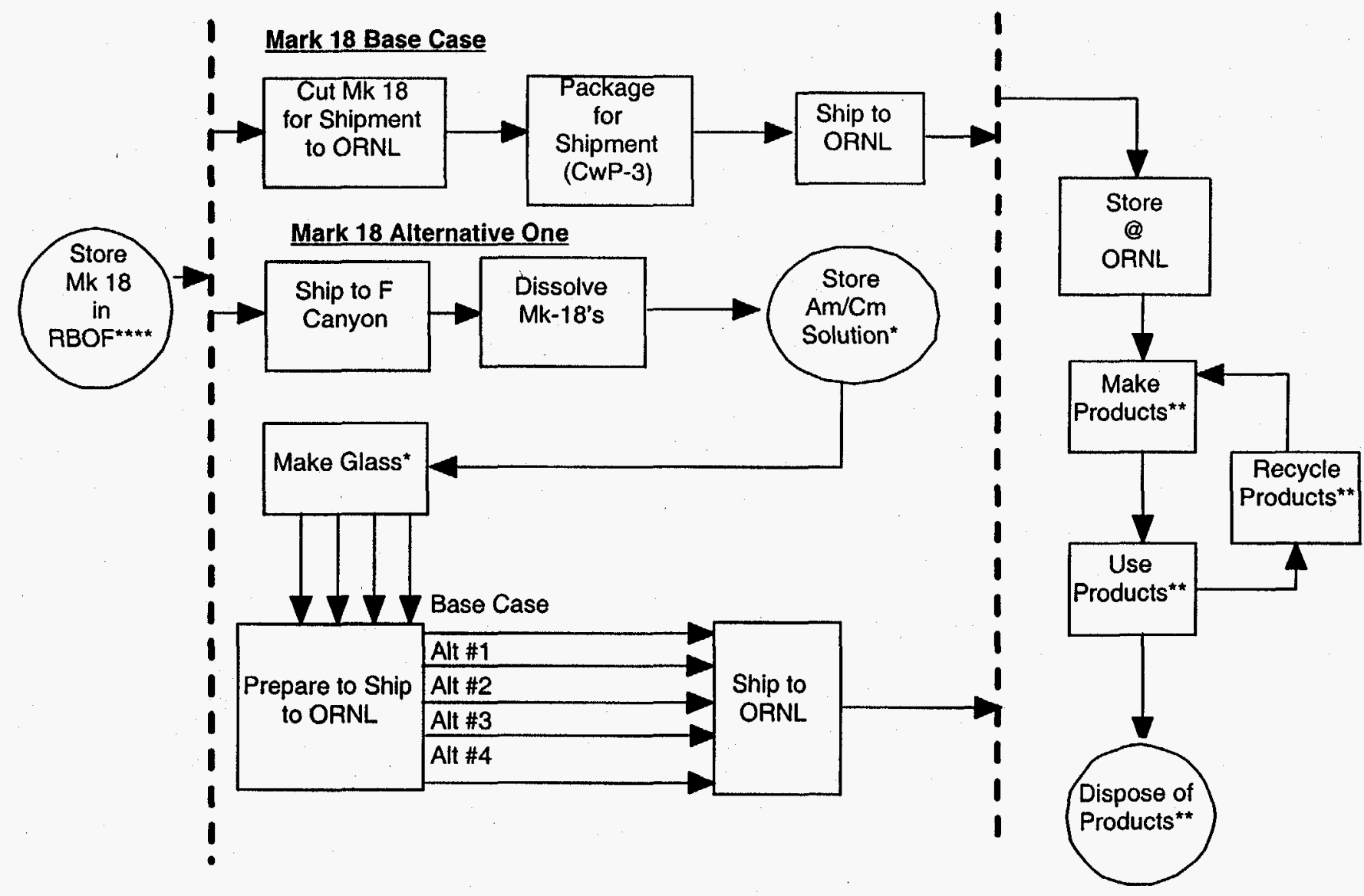




\subsubsection{Slugs/Other Disposition Functional Flow Paths}

\section{Appendix $\mathrm{H}$}

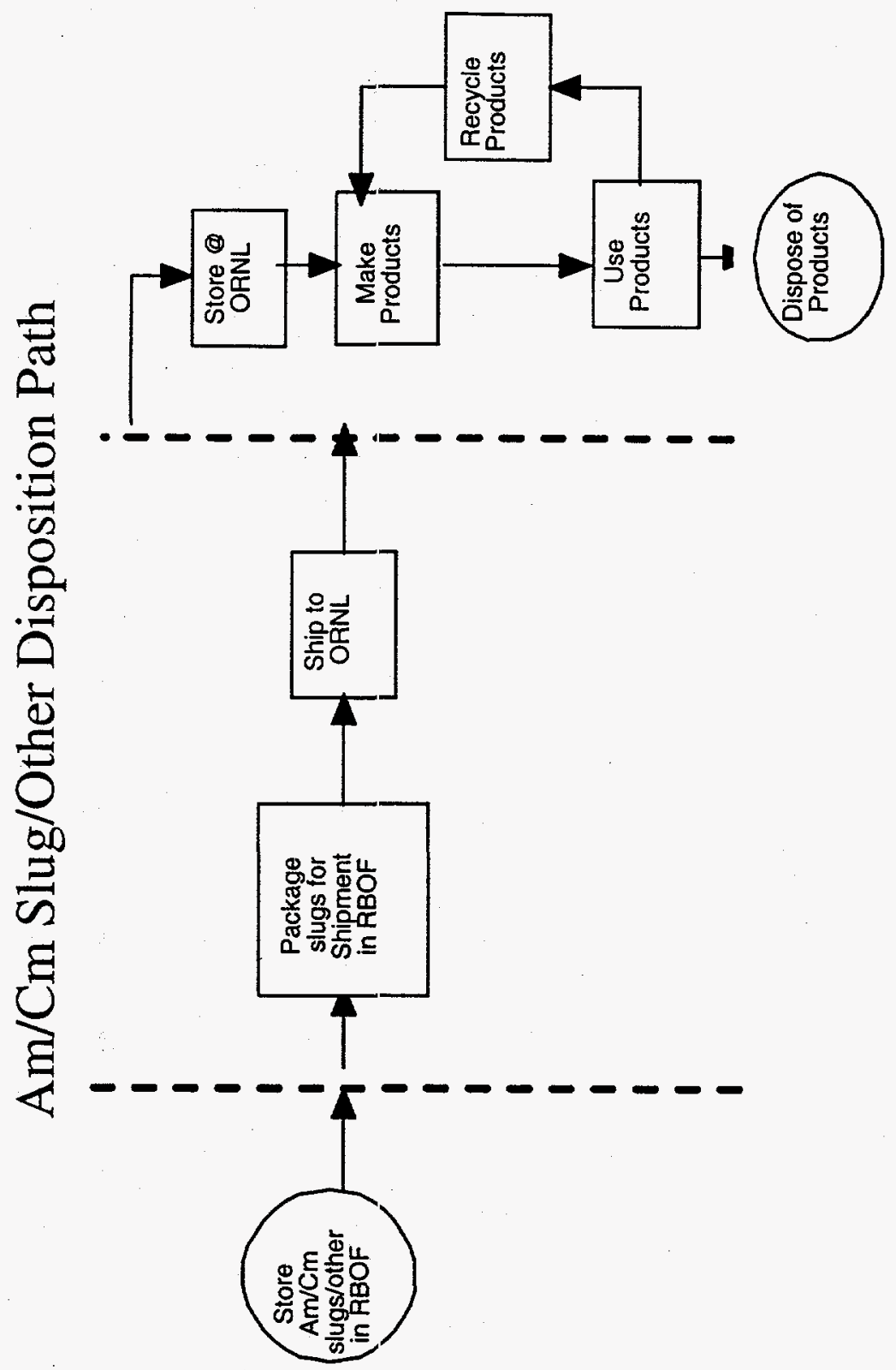




\section{Appendix I}

\subsection{Appendix I - Expanded Base Cases and Alternatives}

Introduction

This appendix provides an expanded review of the Am/Cm Disposition Path overviews shown in Section 6.7.1 through 6.7.9. This review begins with an intermediate look at the primary functions by means of a premise listing, a schedule, process rates, costs breakdowns and repetition of the objectives to be met that would enable the case under review to move forward. Each primary function is then further broken out into a more detailed review by means of including the sub- functions, requirements, interfaces, issues, assumptions and costs.

\subsubsection{Tank 17.1 "Solution" Disposition - Base Case}

\section{Flow chart: Base Case}

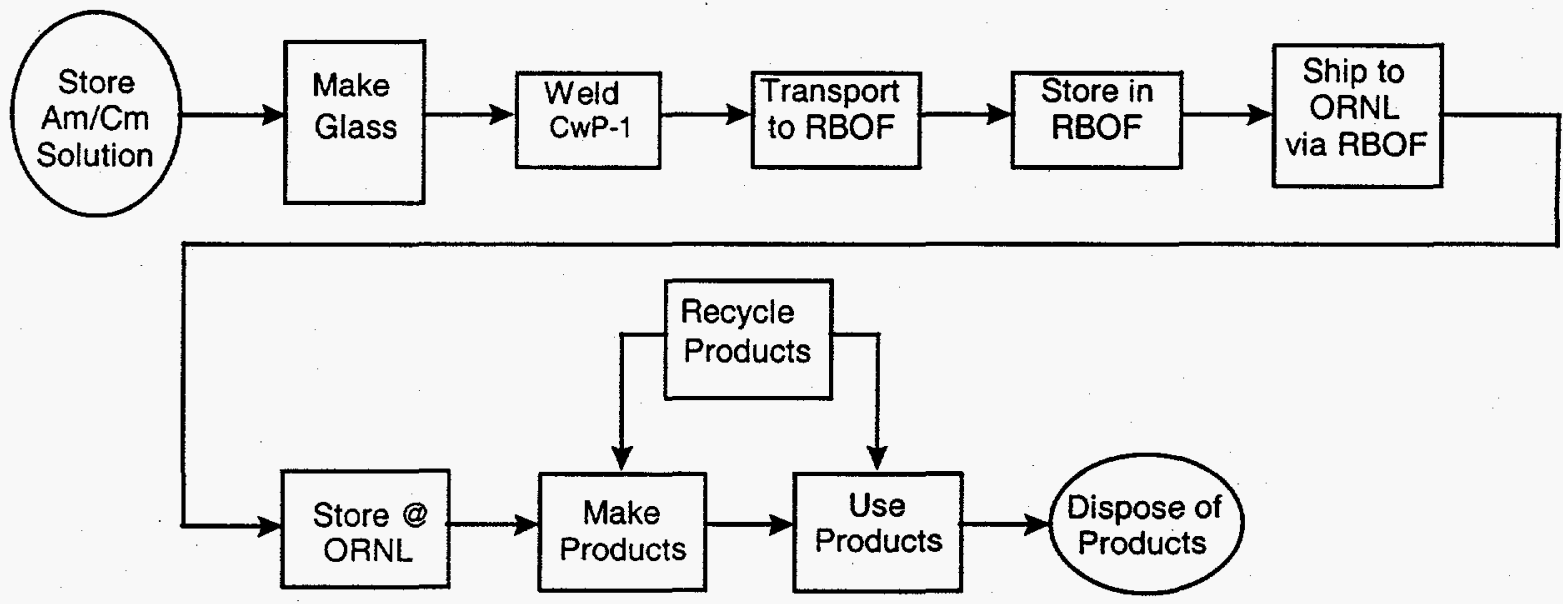

Primary Functions - Base Case

\subsubsection{Make glass}

9.9.1.2 Weld the glass canisters in Containers Qualified per Shipping Requirements (CwP-1)

9.9.1.3 Transport the CWP-1's to RBOF

9.9.1.4 Store CWP-1's in RBOF

9.9.1.5 Ship to ORNL via RBOF

9.9.1.6 Store material at ORNL

\section{Premise: Base case}

- All operations are remotely controlled.

- The $\mathrm{Am} / \mathrm{Cm}$ in solution is immobilized by vitrification.

- The glass is sealed in stainless steel canisters.

- The glass form (canisters) provide no containment function and may require qualified primary and secondary containment for shipping.

- The CwP-1s provide a qualified primary containment function (full penetration weld) around the vitrified $\mathrm{Am} / \mathrm{Cm}$.

- Welding and leak testing are performed within the F-Canyon Multi-Purpose Process Facility (MPPF).

- A Helium atmosphere is provided internal to the primary containment vessel.

- Existing canyon equipment is utilized to transport the CWP-1s through the canyon, decontaminate the CWP-1s, and load the CWP-1s into the on-site shipping cask.

- Transport of the CWP-1s to RBOF is by rail.

- At the Receiving Basin for Off-site Fuel (RBOF) existing equipment is utilized to remove the CwP-1s from the on-site shipping cask, and to place the CwP-1s in lag storage. 


\section{Appendix 1}

- The CWP-1s remain in lag storage in RBOF until ready for shipment to ORNL.

- Prior to leaving RBOF the CWP-1s are decontaminated and loaded into a qualified off-site shipping cask for transport to ORNL.

- ORNL receives the off-site shipping cask, unloads the cask, and stores the CWP-1s.

- The off-site shipping cask is either returned to SRS, or to the company from which it was leased (Depending on cask ownership, and/or leasirg arrangements).

\section{Schedule}

- Glass production of $\mathrm{Am} / \mathrm{Cm}$ to start 7/01 and end between 1/02 to 3/02 (basis: Current Planning Agreements).

- Deactivation PUREX is assumed to begin 10/1/02.

- Round trip for off-site casks to ORNL and back to RBOF is approximately 2 weeks.

- $\quad$ ORNL is to receive all shipments by 2006.

- The qualification and NRC approval, of a double containment cask (if necessary) for shipment of Am/Cm canisters to ORNL may take 3 to 5 years.

Rates

- Canister production to be 25 per month. (Assuming 200 canisters produced from $7 / 01$ to 3/02).

\section{Cost}

- R\&D, Project, Operations/Maintenance costs; (no D\&D) to place canisters/carriers into racks -- \$80M

- Design and installation of welder in MPPF -- $\$ 1.7 \mathrm{M}$

- Design and installation of storage space at CRNL -- $\$ 7 \mathrm{M}$

- Shipment from F Canyon to RBOF -- $\$ 150 \mathrm{~K}$ to $\$ 300 \mathrm{~K}$

- If materials are not removed from RBOF before scheduled RBOF closure, storage costs will be $\$ 10 K$ per week. Since no impact is expected, no clost is included.

- Shipment to ORNL -- $\$ 1.2 \mathrm{M}$ to $\$ 2 \mathrm{M}$

- The qualification and approval, of a double containment cask (if necessary) for shipment of $\mathrm{Am} / \mathrm{Cm}$ canisters to ORNL -- $\$ 1.5 \mathrm{M}$

- The acquisition of a double containment cask (if necessary) for shipment of Am/Cm canisters to ORNL - \$3.0M

- Operational cost of ORNL not included -- Considered an ongoing operation.

- Operational cost for F-Canyon is estimated as within normal operating costs.

Issues

- Establish if off-site shipment of Am/Cm materials to ORNL requires a single or double containment cask. Containment requirements depend on package plutonium contents (up to 20 Curies of plutonium can be shipped in a single containment package).

- In order not to affect D\&D of the F-Canyon, the goal is to remove all the Am/Cm materials (CWP-1s) from F-Canyon as soon as possible.

- If vitrified material remains in F Canyon after D\&D of PUREX is completed (current schedule is FY03) any additional D\&D must consider functions rieeded to remove material from the canyon. If the required functions to remove the Am/Cm are scheduled for D\&D, the costs and risks associated with keeping these functions available will probably be allocated to the Am/CM removal project/program.

\section{Enabling Objectives}

- Obtain funding for further process and equiprnent development

- Complete R\&D project on schedule

- Design and install welder in F Canyon

- Add storage area to ORNL

- Fund operation of $\mathrm{F}$ Canyon systems required to support $\mathrm{Am} / \mathrm{Cm}$ disposition 


\section{Appendix 1}

\subsubsection{Function: Make Glass- Tank 17.1 "Solution"- Base Case}

Sub-Functions

- Perform Pretreatment of Tank 17.1 oxalic acid (remove transition metals, such as $\mathrm{Cr}, \mathrm{Ni}$, and $\mathrm{Fe})$

- Transfer solution from Tank 17.1 to feed tank in Multi-Purpose Processing Facility (MPPF)

- Feed solution to melter and combine with flow of glass frit

- Charge melter \& Vitrify dissolved solids

- Treat off-gas stream if needed

- Drain molten glass from bottom of melter into "canister"

- Seal "canister"

- Transfer sealed canister to "carrier"

- Transfer loaded carrier to "rack" and lag store

- Perform MC\&A (calorimeter measurement)

Requirements:

- Glass product shall be nitric acid soluble (Only process available to ORNL)

- Glass chemistry and canister design are to interface with ORNL \{ORNL equipment will be used to handle canisters\}

- Glass shall be capable of being "broken up" into chunks \{Enables increased surface exposure to nitric acid, which decreases the dissolution time. ORNL proposed process: cut open canister, drill vertically into glass, break up within canister, dump out of canister and crush glass chunks to further decrease size

- Dissolution at ORNL time goal: Two (2) days or less per canister \{lf greater than two days costs become prohibitively high

- During dissolution, silica shall drop out of solution and remain behind in dissolution vessel \{Silica creates problems if carried downstream in ORNL process\}

- Minimize potential RCRA issues, i.e. minimize lead content

- Operations are to be performed remotely and shall be encompassed under each facility Authorization Basis \{Minimize expected worker radiation exposure during operations\}

Note: Verification of product recovery is being performed by WSRC-SRTC sending glass samples to ORNL for testing.

Interfaces

- MPPF equipment (manipulators, turntables, racks, crane, etc.) and new CwP-1 welder installation.

- ORNL chemical and equipment characteristics

Issues:

- Glass loading affects ability to vitrify

- Design and install canister seal/containment welder is not in the budget

- Canyon Authorization Basis deals with Americium Curium in 17.1. Moving the material into a process environment may require USQD be performed to determine mitigating factors. Potential cost impact exists for mitigation factors.

- Pu content may effect shipping.

- Making glass assumes an $80 \%$ reduction in Pu content. If less than 20 curies may not stay that way. Short half life allows Pu 240 \& 241 to creep back in from decay

- Technical Maturity of Americium/Curium vitrification process (R\&D) 


\section{A.ppendix 1}

\section{Assumptions}

- It is assumed that the plutonium content per shipment exceeds 20 Curies. The amount of plutonium per shipment depends on a number of factors, these are: (a) The amount of plutonium removed during pretreatrnent; (b) The total number of glass canisters produced; and (c) The number of glass canisters per shipment. When the plutonium content per shipment exceeds 20 Curies the shipping package is required to incorporate a primary and secondary containment.

- The above assumption must take into account the total number of canisters to be produced. Currently the number of canisters is thought to be in the $150-200$ range.

- An off-site shipping cask may be designed/modified so that it will accept the desired number of canisters without exceeding the casks radiation shielding requirements.

- Project rebaseline being performed 1stQuarter FY99, will conclude $\$ 80 \mathrm{M}$ is correct and will not be exceeded.

\section{Schedule}

- Operations will start 7/01 and end between 1/02 to 3/02. (Basis: Current Planning Agreements)

Cost:

- The overall Cost is $\$ 80 \mathrm{M}$. This Includes all R\&D, Project, Operations/Maintenance costs (no D\&D) to place canisters/carriers into racks

\subsubsection{Function: Weld the glass canister(s) in the CwP-1s - Tank 17.1 "Solution" - Base Case}

\section{Sub-functions}

- Remove canister from lag storage racks

- Load canister into unsealed CwP-1

- Load unsealed CWP-1 into welder

- Full penetration weld the CwP-1s

- Charge CwP-1s with Helium gas

- Perform leak test

- Remove sealed CWP-1 from welder and place in slug basket.

- Repeat functions above, until slug basket is loaded with CwP-1s

\section{Requirements}

- The system shall be capable of transferring a full carrier/slug basket with up to 5 canisters within the MPPF cells.

- CWP-1s shall be qualified as a primary containment barrier.

- $\quad$ ORNL preference; Canister with helium atmosphere so helium leak test may be performed (aids in meeting current SAR)

- CWP-1s shall have a handle/pintle and fit ORNL equipment.

- CwP-1s outside diameter shall not exceed 4" and length shall not exceed 34", including pintle. (ORNL chutes are $4^{\prime \prime}$ ID.)

- Welder modification must be acceptance tested and completely operational when MPPF modifications and current project are complete.

\section{Interfaces}

- MPPF and F-Canyon handling equijment

- $\mathrm{Am} / \mathrm{Cm}$ Vitrification project. 
Issues

Appendix I

- Welder designed by SRTC does not accommodate a full penetration weld.

- There is no Helium supply in the MPPF.

- Room for operation and storage in the MPPF is limited.

- The MPPF is a high contamination area, and welding in this environment to produce a clean surface may be hard. A mitigating approach would be to enclose the welded CWP-1 in an outer mechanically sealed Qualified Shipping Container (msQSC) outside of MPPF.

\section{Assumptions}

- $\quad$ CwP-1 is to provide a qualified primary containment function for shipping.

- Helium is to be used for leak testing purposes.

- Up to two (2) canisters are loaded into each CwP-1.

- Existing F-Canyon equipment is compatible with CwP-1 and/or carrier/slug basket design.

- Existing RBOF equipment is compatible with CwP-1s.

Schedule

- Welder modification must be acceptance tested and complete by $1 / 01$.

- Welding of CwP-2s should be completed before the start of F-Canyon deactivation to make D\&D a non issue, otherwise D\&D may require "engineering/better planning" to insure functions are available.

Cost:

- Design and installation of the welder and weld qualification will add another $\$ 1.7 \mathrm{M}$.

\subsubsection{Function: Transport CwP-1s to RBOF - Tank 17.1 "Solution"- Base Case}

\section{Sub-functions}

- Decontaminate CWP-1s and slug basket.

- Perform radiation survey.

- Load slug basket with CwP-1s into on-site shipping cask

- Complete appropriate paper work, (Railroad dispatch material control and accountability forms).

\section{Requirements}

- All operations including movement of CwP-1s, decontamination, radiation survey and loading of the on-site shipping cask shall be remotely controlled. (Minimize expected worker radiation exposure during operations\}

- Transport shall comply with on-site shipping requirements/regulations, 19Q Manual Radioactive Material Packaging Certification and Authorization Requirements

- Decontaminate CwP-1s to $45,000 \mathrm{dpm} / 100 \mathrm{~cm}^{2}$ (Beta Gamma) and TBD dpm/100 $\mathrm{cm}^{2}$ (Alpha) to qualify for on-site shipment. \{RBOF requirement prior to acceptance criteria in to the facility\}.

- $\quad$ All canisters shall be removed from F Canyon prior to deactivation of the following functions; canyon decontamination cell, crane, and additional functions required for storing material in MPPF.

\section{Interfaces}

- RBOF schedule

- On-site shipping requirements.

\section{Issues}

- Level of radiation is high due to material being handled.

- Present capability of F-Canyon to Decontaminate a vessel to a very low level is limited. 


\section{Appendix I}

- The tasks has not been performed with this material. The F-Canyon Railroad Tunnel has no provision for filling the cask with water. It is not clear if the shipments will include filling the cask with water, or not. Water may be needed to meet shielding requirements.

\section{Assumptions:}

- The loading operation meets the authorization basis limitations.

- Decontamination waste streams rernain within operating basis.

- Approximately 8,000 gallons/batch of decontamination liquids is collected by the High Activity Waste System.

- It is assumed that six (6) glass canisters ( 3 CwP-1s) can be included in each on-site shipment.

- Canyon deactivation may begin in 2002 and end in 2006. It is assumed that all CwP-1s can be removed before the end of F-Canyon deactivation. Functions required of crane and decontamination area are assumed to remain open until the end of F-Canyon deactivation.

\section{$\underline{\text { Cost }}$}

- $\$ 150 \mathrm{~K}-\$ 300 \mathrm{~K}$ for shipment from F Canyon to RBOF dependent on number of canisters.

Schedule

- Start transfer of CwPs to RBOF ASAP (in order not to interfere with F-Canyon and RBOF deactivation and closure dates).

\subsubsection{Function: Store in RBOF- Tank 17.1 "Solution"- Base Case}

\section{Sub-functions}

- Perform radiation survey of cask, while on rail car.

- Unload On-Site Cask and stage cask for underwater unloading of slug basket with CwP-1s

- Unload CwP-1s and place in lag stolage

- Decontaminate slug basket and return it to F-Canyon

\section{Requirements}

- Meet RBOF Material Acceptance Criteria.

- Shipping package has to meet U.S. Department of Transportation, Title 49, CFR Parts 100 through 189, DOE Order 5480.3, and NRC Regulations, Title 10, CFR, Part 71.

- Handling of $\mathrm{Am} / \mathrm{Cm}$ materials shall be remotely controlled.

- All material will have to be shipped out by RBOF closure date in 2006 .

\section{Interfaces}

- F-Canyon schedule

- ORNL Schedule

Issues

- ORNL requirements are not fully defined.

- Final number and design of CWP-1s is not detailed.

\section{Assumptions}

- Each CwP-1s contains 2 canisters and RBOF gets 3 CwP-1s per shipment.

- Only minor modifications and little if any training will be required to handle the material.

- Heat load does not become an issue.

\section{Schedule}

- 24 hours are required to have a cask emptied and waiting on smear to return to canyon. RBOF closure date is 2006. 
WESTINGHOUSE SAVANNAH RIVER COMPANY

Americium/Curium Disposition Life Cycle Planning Study(U)
Document: NMP-PLS-980044

Revision 0

April 30, 1998

Page 65 of 159

Cost

\section{Appendix I}

- If storage delays RBOF decommissioning the cost is $\$ 10 \mathrm{~K}$ per week. 


\section{A.ppendix I}

\subsubsection{Function: Ship to ORNL via RBOF- Tank 17.1 "Solution"-Base Case}

Sub-functions:

- Stage off-site cask for shipping.

- Leak Test CwP-1s

- Place CwP-1s in cavity of off-site cask.

- Seal the package in the wet pit, transifer to dry pit, and decontaminate package.

- Load package on flat bed truck and prepare for shipment.

Requirements:

- Leak Test CWP-1s: To meet "Special Shipment" the vessel qualified as a "containment" vessel, must be leaked tested within one year of shipment.

- Shipping package has to meet U.S. Department of Transportation, Title 49, CFR Parts 100 through 189, DOE Order 5480.3, and NRC Regulations, Title 10, CFR, Part 71

- The loading of the off-site shipping cask is to be remotely controlled.

- CwP-1s and associated pintle are to be centered in the shipping sleeve for retrieval by ORNL equipment.

- The off-site shipping cask will have to satisfy: (a) Shielding requirements; (b) Containment requirements; and (c) Heat generation rate.

- RBOF will be available until 2006 and all materials stored in the facility will have to be removed by this date.

- Decontaminate casks to $2,200 \mathrm{dpm} / 100 \mathrm{~cm}^{2}$ (Beta Gamma), TBD dpm/100 cm (Alpha) to qualify for Off-Site Shipment.

Interfaces

- ORNL facility, equipment and schedule

- NRC \& DOT - Shipping Cask Qualification

Issues

- It is not clear if the off-site shipping cask (package) for $\mathrm{Am} / \mathrm{Cm}$ canisters will require double or single containment. Containment requirements will depend on package plutonium contents (up to 20 Curies of plutonium can be shipiped in a single containment package). The plutonium content of the canisters is not known at this stage. Tank 17.1 is estimated to contain a total of approximately $2.5 \mathrm{~kg}$ of various plutonium isotopes. However, it is not known: (a) How much of the plutonium will be removed during pretreatment; and (b) The exact number of canisters to be produced. Single containment casks may be available and can be leased. However, double containment casks are not readily available. This may result in the following: (a) A new double containment cask will have to be deviloped and licensed (a major undertaking); or (b) the number of canisters included in each off-site shipment will have to be limited.

- The design and licensing of a double containment cask for shipment of Am/Cm to ORNL may take 4 years complete and cost $\$ 4$ Million.

- The number of canisters that can be loaded in a single cask also depends on shielding considerations. The Am/ $\mathrm{Cm}$ canisters are highly radioactive, and loading too many canisters in a single cask may result in excessive dose rates around the cask. The acceptable number for a particular cask will have to be establisined by analysis.

- There are no shipping facilities available after RBOF shuts down

- The ORNL receiving requirements and acceptable CWP-1 requirements are not firm

\section{Assumptions}

- Cask certified for transportation of $\mathrm{Anv} / \mathrm{Cm}$ canisters is obtained. This may include the leasing of an existing cask or the certification of a new cask. 


\section{Appendix I}

- Prepare Safety Analysis Report for off-site shipping package (SAR), and obtain approval from DOT is complete.

- ORNL has new storage room available and equipment and personnel are ready for receipt

Schedule

- RBOF will be available until 2006

- Rate From time the off-site cask is received at RBOF, it can be ready to return to ORNL in 72 hour.

Cost

- The qualification and approval, of a double containment cask (if necessary) for shipment of $\mathrm{Am} / \mathrm{Cm}$ canisters to ORNL - $\$ 1.5 \mathrm{M}$

- The acquisition of a double containment cask (if necessary) for shipment of Am/Cm canisters to ORNL -- \$3.OM

- Cask rental and shipment costs for 150-200 canisters at eight per shipment -- \$1.2-2.0M

\subsubsection{Function: Store material at ORNL- Tank 17.1 "Solution"- Base Case}

Sub-functions

- Perform contamination survey.

- Unload off-site shipping cask from truck flatbed.

- Remove cask lid and spacer.

- Place unloading lid on the cask. This provides for a small opening (pie shaped) through which cask contents are unloaded.

- Place Transfer Cask on top of off-site cask (Transfer cask has a special pick-up tool that allows Pulling one CwP-1 at a time out of the cask into the transfer cask)

- Use Transfer Cask to unload CwP-1s into hot cells.

\section{Requirements}

- Unloading and storage operations are performed remotely.

- CwP-1s are shipped to ORNL and stored in hot cell, must have pintle on one end.

- The CWP-1s received and stored at ORNL for this "Base Case" shall meet long term storage criteria.

- Dimensions of equipment received shall interface with ORNL handling storage facilities.

Interfaces

- ORNL facility, equipment and schedule

- SRS facility shipping schedule

- NRC \& DOT - Shipping Cask Qualification

Assumptions

- The higher heat loading to the storage facility is within the operating basis, and can be handled with minor modifications to existing ventilation systems.

- Neutron source terms will not present a significant issue.

- If the material can be shipped, ORNL can accept it.

Issues

- There is no ORNL Acceptance Criteria in writing.

- Multiple interfaces implies probable schedule delays.

Schedule

- RBOF will be available until 2006

- Rate from time the off-site cask is received at RBOF, it can be ready to return to ORNL in 72 hour. 
WESTINGHOUSE SAVANNAH RIVER COMPANY

Americium/Curium Disposition Life Cycle Planning Stıdy(U)
Document: NMP.PLS-980044

Revision 0

April 30, 1998

Page 68 of 159

\section{Aspendix I}

- Following 4days from arrival @ OFNL cask can be ready for off-site shipment to SRS.

- ORNL will take shipments until year 2006.

Cost

- New facility storage area will cost $\$ 7 \mathrm{M}$ assuming Pu238 project shares part of cost.

- On site operations are on going and add no additional cost 


\section{Appendix 1}

\subsubsection{Tank 17.1 "Solution" Disposition - Alternative One}

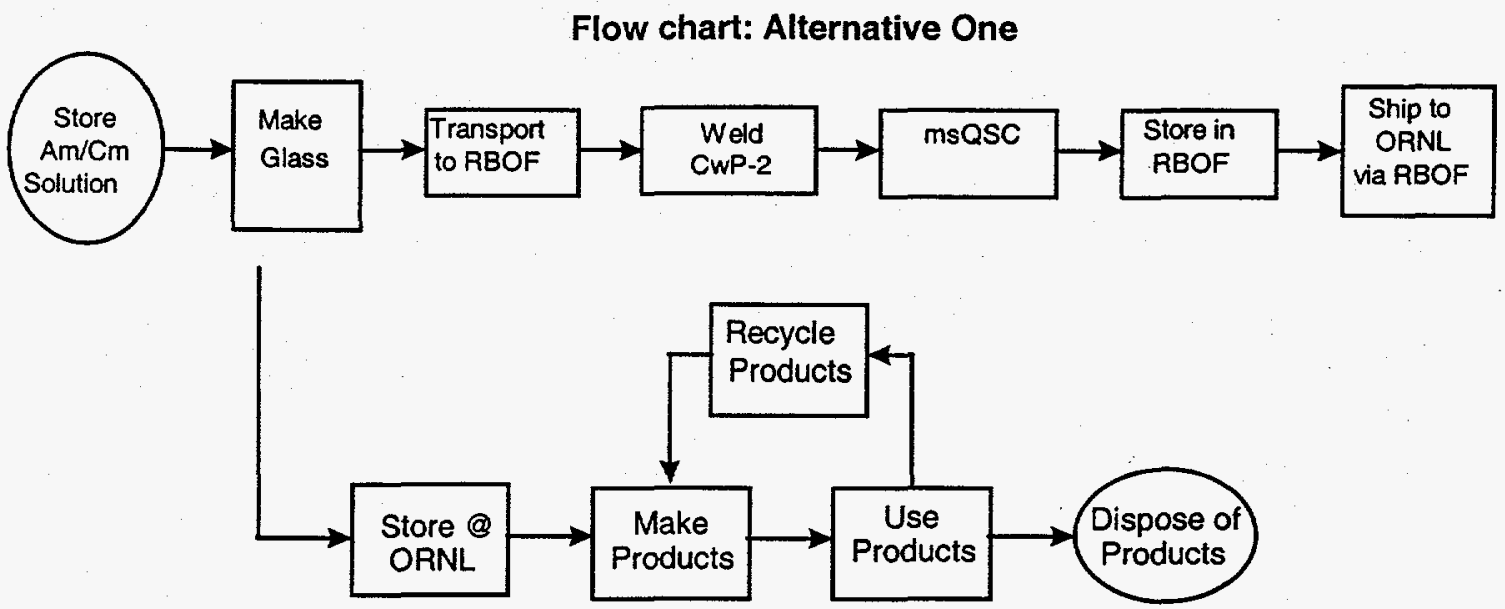

Primary functions - Tank 17.1 Solution - Alternative One

\subsubsection{Make glass}

9.9.2.2 Transport glass canisters to RBOF

9.9.2.3 Weld glass canister(s) in CwP-3

9.9.2.4 Enclose CwP-3(s) in (msQSC)

9.9.2.5 Store in RBOF

9.9.2.6 Ship to ORNL via RBOF

9.9.2.7 Store material at ORNL

Premise: Alternative One

- All operations are remotely controlled

- The $\mathrm{Am} / \mathrm{Cm}$ in solution is immobilized by vitrification

- The glass is sealed in stainless steel canisters in the F-Canyon Multi-Purpose Process Facility (MPPF).

- The canisters are decontaminated in F-Canyon and transported to the Receiving Basin for Off-Site Fuel (RBOF).

- The canisters provide no containment function and must have a primary and secondary containment for shipping.

- Existing F-Canyon equipment is utilized to place the canisters in slug baskets, transport through the canyon, decontaminate the canisters, and load canisters into the on-site shipping cask.

- At the Receiving Basin for Off-Site Fuel (RBOF) existing equipment is utilized to remove the canisters from the-on-site shipping cask.

- The on-site shipping cask is returned to F-Canyon.

- Welding equipment installed in RBOF performs seal welding of CWP-3s

- A Helium atmosphere is provided internal to the CWP-3s.

- Leak testing and decontamination of CWP-3s are performed within the RBOF.

- The welded containment vessel is placed in a Mechanical Sealed (bolted) Qualified Shipping Container.

- RBOF lag stores the msQSC until ready for shipment to ORNL.

- RBOF loads the mSQSC into a qualified Off-Site shipping cask for transport to ORNL.

- The Off-Site transport cask into which the msQSC are placed is qualified as a secondary containment for shipment.

- ORNL receives the Off-Site shipping cask, unloads the msQSC, stores the msQSC, and returns the offsite shipping cask to SRS. 
Schedule

\section{Appendix 1}

- Glass production of $\mathrm{Am} / \mathrm{Cm}$ to start 1/01and end between 1/02 to 3/02 (basis: Current Planning Agreements)

- Deactivation of the PUREX may start on 10/1/02. In order not to affect D\&D of F-Canyon, the goal is to remove all the Am/Cm materials (glass canisters) from F-Canyon as soon as possible.

- Round trip for Off-Site casks to ORNL and balck to RBOF is about 2 weeks

- ORNL is to receive all shipments (including Mlark 18s) by FY2006.

Rates

- Canister production to be 25 per month. (Assuming 200 canisters produced from $7 / 01$ to $3 / 02$ ).

Cost

- R\&D, Project, Operation/Maintenance costs (no D\&D) to place canisters/carriers into racks -- $\$ 80 \mathrm{M}$

- Shipment to RBOF -- $\$ 150 \mathrm{~K}$ to $\$ 300 \mathrm{~K}$

- Design and installation of a welder in RBOF - $\$ 3$

- Operational cost of F-Canyon and RBOF not included -- Ongoing operation for glass

- Shipment to ORNL -- \$1.2 to \$2M

- The qualification, approval, and licensing of a double containment cask (if necessary) for shipment of Am/Cm canisters to ORNL -- $\$ 1.5 \mathrm{M}$

- The acquisition of a double containment cask (if necessary) for shipment of Am/Cm canisters to ORNL $-\$ 3.0 \mathrm{M}$

- Design and installation of storage space at ORNL -- $\$ 7 \mathrm{M}$

- Operational cost of ORNL not included -- Oncjoing operation.

Issues

- Establish if off-site shipment of Am/Cm materials to ORNL requires a single or double containment cask. Containment requirements depend on package plutonium contents (up to 20 Curies of plutonium can be shipped in a single containment packáıge).

Enabling Objectives

- Obtain funding for further process and equipment development

- Complete R\&D project on schedule

- Design and install welder in RBOF

- Add storage area to ORNL

- Fund operation of $\mathrm{F}$ Canyon systems required to support $\mathrm{Am} / \mathrm{Cm}$ disposition.

\subsubsection{Function: Make Glass - Tank 17.1 Solution Disposition - Alternative One}

See Function 9.9.1.1 - Make Glass - Base Case

\subsubsection{Function: Transport glass canisters to RBOF - Tank 17.1 Solution Disposition - Alternative One}

Sub-functions

- Remove canister from lag storage racks

- Repeat functions above, until a slug basket is loaded with 5 to 6 canisters

- Decontaminate canisters and slug basket

- Perform radiation survey

- Load slug basket into on-site shippirıg cask

- Complete appropriate paper work, (Railroad dispatch material control and accountability forms). 


\section{Appendix I}

Requirements

- All operations including movement of canisters, decontamination, radiation survey and loading of the on-site shipping cask shall be remotely controlled. (Minimize expected worker radiation exposure during operations).

- The system shall be capable of transferring a full carrier/slug basket with up to 6 canisters within the MPPF cells.

- Transport shall comply with on-site shipping requirements/regulations, 19Q Manual Radioactive Material Packaging Certification and Authorization Requirements

- Decontaminate canisters to less than $45,000 \mathrm{dpm} / 100 \mathrm{~cm}^{2}$ (Beta Gamma) and TBD dpm/100 $\mathrm{cm}^{2}$ (Alpha) to qualify for on-site shipment. \{RBOF requirement for acceptance criteria into the facility\}.

- All canisters shall be removed from F-Canyon prior to deactivation of the following functions: Canyon decontamination cell, crane, and additional functions required for storing material in MPPF.

Interfaces

- MPPF and $\mathrm{F}$ Canyon handling equipment

- Am/Cm Vitrification project

- RBOF schedule

- On-site shipping requirements

Issues

- Level of radiation is high due to material being handled.

- Present capability of F-Canyon to Decontaminate a vessel to a very low level is limited.

- The tasks have not been performed with this material. The F Canyon Railroad Tunnel has no provision for filling the cask with water. It is not clear if the shipments will include filling the cask with water, or not. The need for water is based on shielding requirements.

Assumptions:

- The loading operation meets the authorization basis limitations.

- Slug basket is used as canister carrier and loaded into site CD cask.

- Decontamination waste streams remain within operating basis.

- Approximately 8,000 gallons/batch of decontamination liquids is collected by the High Activity Waste System.

- It is assumed that six (6) glass canisters can be included in each on-site shipment.

- Canyon deactivation begins in 2002 and ends in 2006. It is assumed that all canisters can be removed before the end of $\mathrm{F}$-Canyon deactivation. Functions required of crane and decontamination area are assumed to remain open until the end of F-Canyon deactivation.

\section{$\underline{\text { Cost }}$}

- Shipment to RBOF -- \$150K - \$300K

\section{Schedule}

- Start transfer of CWPs to RBOF ASAP (in order not to interfere with F-Canyon and RBOF deactivation and closure dates). 


\section{A.ppendix I}

\subsubsection{Function- Weld Glass Canisters in CinP-3 - Tank 17.1 Solution Disposition - Alternative One}

Sub-functions

- Perform radiation survey of cask, while on rail car.

- Unload On-Site Cask and stage cask for underwater unloading of slug basket with canisters

- Unload canisters and place in lag storage

- Load every two canisters into an unsealed CWP-3

- Load unsealed CwP-3 into welder

- Seal weld the CwP-3 and Charge with Helium gas

- Perform leak test

- Remove sealed CWP-3 from welder and place in msQSC.

Requirements

- Welder must be compatible with under water environment, RBOF equipment, canister and CWP-3 design

- ORNL preference; CWP-3 with helium atmosphere so helium leak test may be performed (aids in meeting current SAR)

- CWP-3 shall have a handle/pintle and fit ORNL equipment.

- CWP-3 outside diameter shall not exceed 4" and length shall not exceed 34", including pintle. (ORNL chutes are $4^{\prime \prime}$ ID).

Interfaces

- RBOF schedule

- RBOF remote handling equipment

- On-site shipping requirements

Issues

- No experience with welding in RBOF

- Welding will require special training of workers

- Impact of storing multiple potentially leaky canisters in terms of contamination on RBOF operations.

- The design of the welder is still pre-conceptual

- A NEPA checklist would be required

Assumptions

- The welding can be performed under water.

- The CWP-3 is to provide a confinement function.

- Helium is to be used for leak testing purposes.

- Two canisters are loaded into each CwP-3.

- The weld of the CwP:3 is not a full penetration weld.

- Radiation levels do not constitute a randling problem for RBOF or ORNL.

\section{Schedule}

- The welder must be installed, acceptance tested, and complete by $3 / 02$.

Cost:

- The cost of the welder is estimated a.t $\$ 3 M$. 


\section{Appendix 1}

\subsubsection{Function: Enclose CwP-3(s) in msQSC - Tank 17.1 Solution Disposition - Alternative One}

Sub-functions

- Place two CWP-3 into each msQSC

- Place cover on MSQSC and torque bolts

- Stage msQSCs for lag storage.

Requirements

- All operations are to be remotely controlled

- The msQSCs shall meet ORNL equipment interfaces (i.e., pintle for handling).

Interfaces

- RBOF schedule

- RBOF remote handling equipment.

Issues

- ORNL will have to develop the means for opening the msQSCs while still in the shipping cask, so that CWP-3s can be unloaded

- The design of the CWP-3s and msQSCs is still pre-conceptual.

Assumptions

- Each msQSC contains two (2) CwP-3s

- Canister contamination is low enough to achieve a low level contamination of the CWP-3s.

Schedule

- RBOF will be available until 2006.

Cost

- Operations assumed to be within RBOF operating costs.

- Cost of msQSCs is assumed to be $\sim \$ 5 \mathrm{~K}$ each -- $\$ 90-130 \mathrm{~K}$

\subsubsection{Function: Store in RBOF- Tank 17.1 Solution Disposition - Alternative One}

Sub-functions

- Place msQSCs in lag storage.

Requirements

- Handling of $\mathrm{Am} / \mathrm{Cm}$ materials shall be remotely controlled

- All material will have to be shipped out by RBOF closure date estimated at 2006.

Interfaces

- RBOF schedule

Issues

- Perform criticality and radiation analysis prior to lag storage at RBOF

- Final number and design of mechanically sealed containers (msQSCs) is not defined.

Assumptions

- Each msQSC contains two (2) CwP-3s and ORNL gets two (2) msQSCs per shipment. 


\section{Appendix I}

Schedule

- RBOF closure date is 2006.

$\underline{\text { Cost }}$

- If decommissioning of RBOF is delayed, operating cost is $\$ 10 \mathrm{~K}$ per week.

\subsubsection{Function: Ship to ORNL via RBOF - Tank 17.1 Solution Disposition - Alternative One}

See Tank 17.1 Solution Disposition - Base Case- Function 9.9.1.5

\subsubsection{Function: Store material at ORNL - Tank 17.1 Solution Disposition - Alternative One}

See Tank 17.1 Solution Disposition - Base Case- Function 9.9.1.5

Exceptions:

Requirements

- $\quad$ The msQSCs shipped to ORNL shall interface with Cask handling/unloading equipment.

- CWP-3 shipped to ORNL and stored in hot cell must have pintle on one end.

Assumptions

- ORNL will handle CWP-3 because canister contamination will be high.

Issues

- Seal welded CWP-3 may not satisfy long term storage requirements. 


\section{Appendix 1}

\subsubsection{Tank 17.1 "Solution" Disposition - Alternative Two}

\section{Flow chart: Alternative Two}

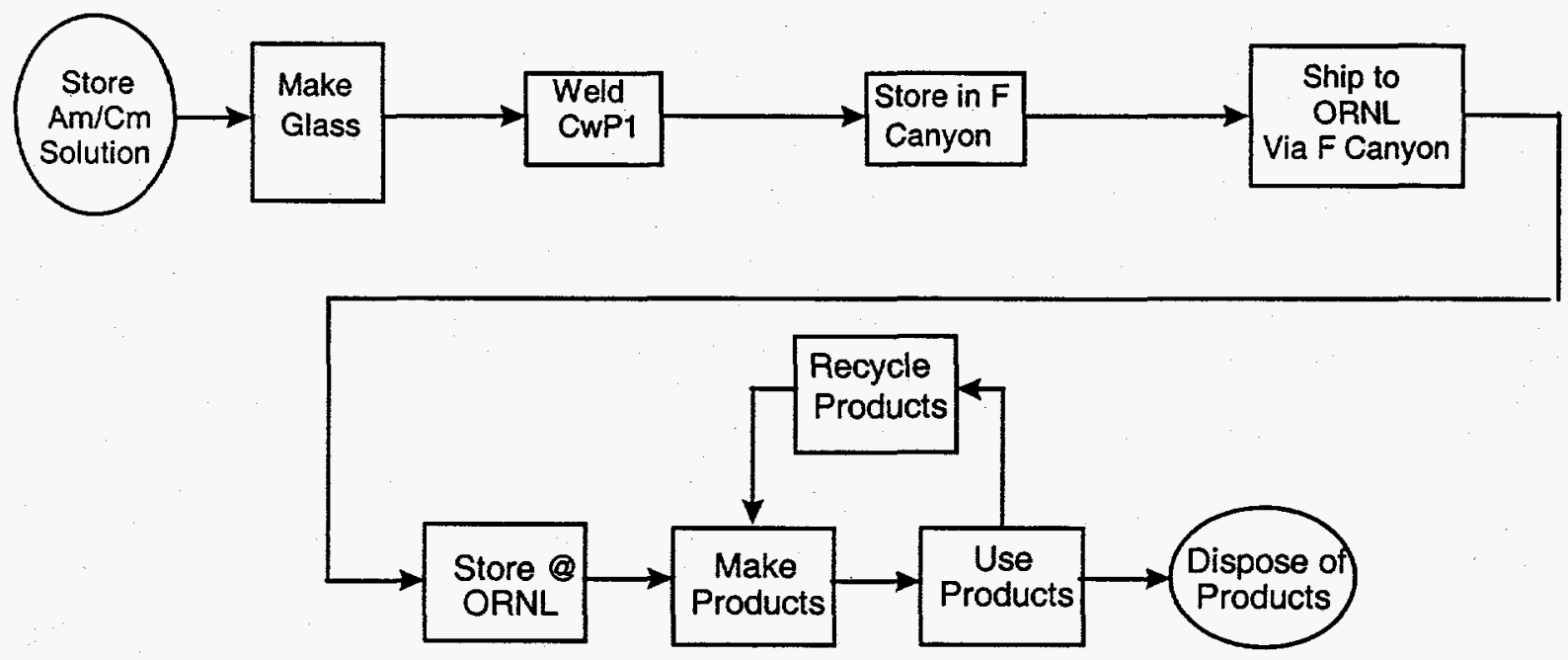

Primary functions -- Alternative Two

\subsubsection{Make glass}

9.9.3.2 Weld glass canister(s) in CwP-1(s)

9.9.3.3 Store in F-Canyon

9.9.3.4 Ship to ORNL via F-Canyon

9.9.3.5 Store material at ORNL

\section{Premise: Alternative Two}

- All operations are remotely controlled.

- The $\mathrm{Am} / \mathrm{Cm}$ in solution is immobilized by vitrification.

- The glass is sealed in stainless steel canisters.

- The glass form (canisters) provide no containment function and may require qualified primary and secondary containment for shipping.

- The CWP-1s provide a qualified primary containment function (full penetration weld) around the vitrified $\mathrm{Am} / \mathrm{Cm}$.

- Welding and leak testing are performed within the F-Canyon Multi-Purpose Process Facility (MPPF).

- A Helium atmosphere is provided internal to the primary containment vessel.

- MPPF equipment is utilized to place the CwP-1s in storage in the MPPF cell.

- Existing canyon functions and equipment will be available (e.g., crane, decon cell, railroad tunnel, air locks, etc.).

- ORNL receives the Off-site shipping cask, unloads the cask, and stores the CwP-1s as a unit.

- The off-site shipping cask is either returned to SRS, or to the company from which it was leased (Depending on cask ownership, and/or leasing arrangements).

\section{$\underline{\text { Schedule }}$}

- Glass production of $\mathrm{Am} / \mathrm{Cm}$ to start 7/01 and end between 1/02 to 3/02 (basis: Current Planning Agreements).

- Deactivation of the F-Canyon will start on 10/1/02. In order not to affect D\&D of the F-Canyon, the goal is to remove all the $A m / C m$ materials (CWP-1s) from F-Canyon as soon as possible. 


\section{Appendix 1}

- Round trip for off-site cask to ORNL and back to F-Canyon is approximately two (2) weeks.

- ORNL will receive all shipments by 2006.

- The qualification and NRC approval, of a double containment cask (if necessary) for shipment of $\mathrm{Am} / \mathrm{Cm}$ canisters to ORNL may take 3 to 5 years.

\section{Rates}

- Canister production will be 25 per month. (Assuming 200 canisters produced from $7 / 01$ to $3 / 02$ ).

Cost

- R\&D, Project, Operations/Maintenance costs (no D\&D) to place canisters/carriers into racks - $\$ 80 \mathrm{M}$

- Design and installation of welder in MPPF - $\$ 1.7 \mathrm{M}$

- Operational cost of F-Canyon not included - Ongoing operation.

- The qualification and approval, of a double containment cask (if necessary) for shipment of $\mathrm{Am} / \mathrm{Cm}$ canisters to ORNL -- $\$ 1.5 \mathrm{M}$

- The acquisition of a double containment cask (if necessary) for shipment of Am/Cm canisters to ORNL -- \$3.0M.

- Shipment to ORNL - $\$ 1.2$ to $\$ 2 M$

- Storage at ORNL - $\$ 7 \mathrm{M}$

Issues

- Establish if off-site shipment of $\mathrm{Am} / \mathrm{Cm}$ materials to ORNL requires a single or double containment cask. Containment requirements depend on package plutonium contents (up to 20 Curies of plutonium can be shipped in a single containment packiage).

- Decontamination performed at F-Canyon may require an additional enclosure (building) due to weather.

- F Canyon cask handling equipment may neeid modification

- Addition of another railroad spur may be required depending on F-canyon schedule impact.

\section{Enabling Obiectives}

- Obtain funding for further process and equipment development

- Complete R\&D project on schedule

- Design and install welder in $\mathrm{F}$ Canyon

- Buy/adapt F Canyon crane handling component/capabilities

- Add storage area to ORNL

- Fund operation of F Canyon systems required to support $\mathrm{Am} / \mathrm{Cm}$ disposition.

\subsubsection{Function - Make Glass - Tank 17.1 Solution Disposition - Alternative Two}

See Function 9.9.1.1 - Make Glass - Base Case

9.9.3.2. Function - Weld glass canister(s) in CiwP-1 (s) - Tank 17.1 Solution Disposition - Alternative Two

See Function 9.9.1.2 - Tank 17.1 Solution Disposition - Base Case

\subsubsection{Function - Store in F Canyon - Tank 17.1 Solution Disposition -Alternative Two}

Sub-functions

- Place CWP-1 and carriers in lag storage rack in MPPF. 
Appendix I

Requirements

- All operations including movement, decontamination, radiation survey and storage of CwP-1 shall be remotely controlled. (Minimize expected worker radiation exposure during operations).

- Deactivation of the F-Canyon will start on 10/1/02. In order not to affect D\&D of the F-Canyon, the goal is to remove all the $\mathrm{Am} / \mathrm{Cm}$ materials (CWP-1) from F-Canyon as soon as possible.

\section{Interfaces}

- F-Canyon schedule.

Issues

- Perform radiation shielding analysis to assess impact on operating areas dose rates.

\section{Assumptions}

- The loading operation meets the authorization basis limitations.

- Functions required of crane and decontamination area are assumed to remain open until the end of F-Canyon deactivation.

\section{$\underline{\text { Cost }}$}

- Costs are assumed to be within F Canyon operating costs

Schedule

- Maintain in storage until all materials are shipped to ORNL.

\subsubsection{Function - Ship to ORNL via F Canyon - Tank 17.1 "Solution" Disposition - Alternative Two}

\section{Sub-functions:}

- Stage Empty Truck Cask outside of F Canyon.

- Transfer Truck Cask to Rail Car.

- Move Loaded Rail Car into F-Canyon Railroad Tunnel.

- Leak Test CwP-1s.

- Decontaminate Cwp-1s

- Place CwP-1s in cavity of off-site cask.

- Move Rail Car with Loaded Cask out of F-Canyon.

- Decontaminate cask

- Transfer Off-Site Cask From Rail Car To Truck Flat Bed And Prepare For Shipment.

- _ Ship by Truck to ORNL

\section{Requirements:}

- $\quad$ Shipping package has to meet US Department of Transportation, Title 49, CFR Parts 100 through 189, DOE Order 5480.3, and NRC Regulations, Title 10, CFR, Part 71.

- The loading of the off-site shipping cask is to be remotely controlled.

- A cradle must be provided to prevent cask tip over during up ending operation.

- Crane(s) shall be capable of horizontal cask movement and up ending.

- The capability to attach rigging and chokers as well as bolt removal and torgue (including but not limited to cask top bolts) shall be provided.

- Cask wash down, pressurization and leak testing capabilities shall be available in $\mathrm{F}$ Canyon railroad tunnel.

- Decontaminate casks to $2,200 \mathrm{dpm} / 100 \mathrm{~cm}^{2}$ (Beta Gamma),TBD (Alpha), to qualify for OffSite Shipment. 


\section{Appendix I}

- The off-site shipping cask will have to satisfy: (a) Shielding requirements; (b) Containment requirements; and (c) Heat generation rate.

- CWP-1 and associated pintle are to be centered in the shipping sleeve for retrieval by ORNL equipment.

- $\quad$ Rigging and chokers must be provided

Interfaces

- ORNL facility, equipment and schedule.

- NRC \& DOT - Shipping Cask Qualification.

Issues

- It is not clear if the off-site shipping cask (package) for $\mathrm{Am} / \mathrm{Cm}$ canisters will require double or single containment. Containment requirements depend on package plutonium contents (up to 20 Curies of plutonium can be shipped in a single containment package). The plutonium content of the canisters is not known at this stage. Single containment casks are generally available and can be leased. However, double containment casks are not readily available. The qualification, licensing, and acquisition of a double containment cask for shipment of $\mathrm{Am} / \mathrm{Cm}$ materials may cost $\$ 4.5 \mathrm{M}$, and may take 3 to 5 years.

- Canyon operating staff will be required for loading and shipping until process is completed.

- Decontamination shed may be needed.

- It may take up to two weeks to decontaminate the CwP-1s and to load the off-site cask.

\section{Assumptions}

- Extent of $\mathrm{F}$ Canyon crane upgrade or modification is minor.

- Cask certified for transportation of $\mathrm{Am} / \mathrm{Cm}$ canisters is obtainable. This may include the leasing of an existing cask or the certification of a new cask.

- ORNL has new storage room available and equipment and personnel are ready for receipt of Am/Cm Materials.

- It is assumed that $A m / C m$ operations will not interfere with $D \& D$.

- Current 50 Ton crane will have adequate capacity

- All operations for decontamination and cask handling may be performed with the existing crane and facilities with minor modfication.

Schedule

- One full day is required for F Canyon to prepare the cask for loading.

- Two full days are required to prepare a cask for shipment.

Cost

- The qualification and approval, of $\varepsilon$. double containment cask (if necessary) for shipment of Am/Cm canisters to ORNL -- \$1.5M

- The acquisition of a double containment cask (if necessary) for shipment of Am/Cm canisters to ORNL -- \$3.0M.

- $\quad$ Shipment to ORNL -- $\$ 1.2-2.0 \mathrm{M}$

\subsubsection{Function - Storing @ ORNL- Tank 17.1 "Solution" Disposition - Alternative Two}

See Function 9.9.1.6 - Tank 17.1 Solution Disposition - Base Case 


\section{Appendix I}

\subsubsection{Tank 17.1 "Solution" Disposition - Alternative Three}

Flow chart: Tank 17.1 Solution Disposition - Alternative Three

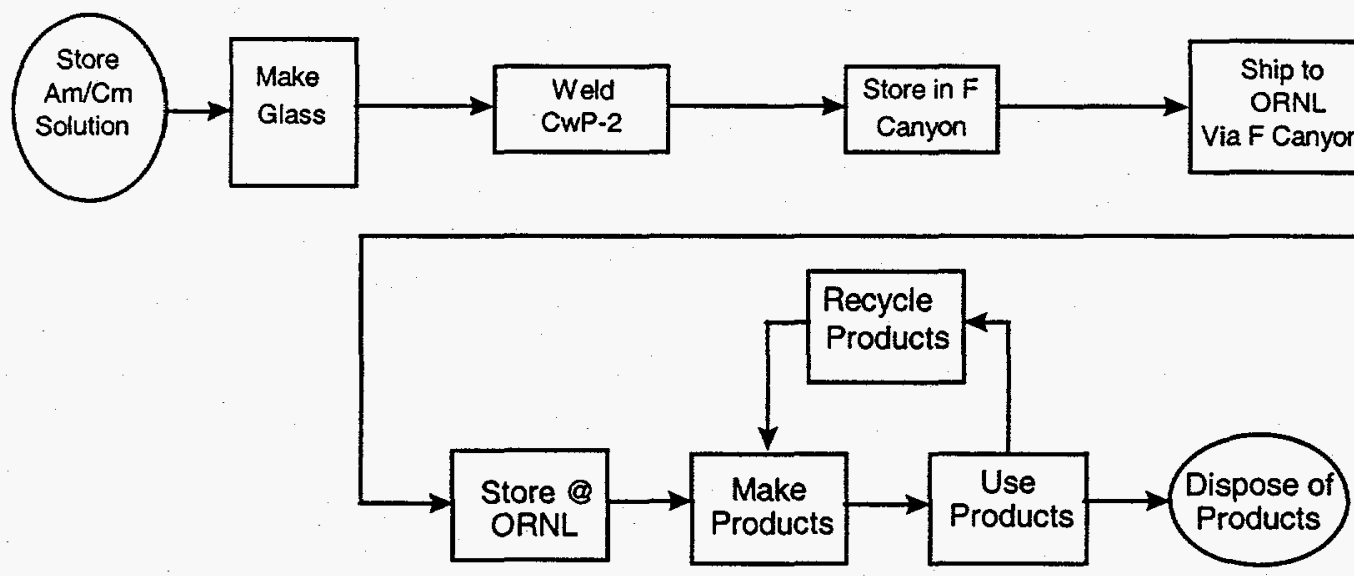

Primary functions - Tank 17.1 Solution Disposition - Alternative Three

\subsubsection{Make glass}

9.9.4.2 Weld glass canister(s) in CwP-2

9.9.4.3 Store in F-Canyon

9.9.4.4 Ship to ORNL via F-Canyon

9.9.4.5 Store material at ORNL

Premise: Alternative three

- All operations are remotely controlled.

- The $\mathrm{Am} / \mathrm{Cm}$ in solution is immobilized by vitrification.

- The glass is sealed in stainless steel canisters in the F-Canyon Multi-Purpose Process Facility (MPPF).

- The canisters provide no containment function and will need a primary and secondary containment for shipping.

- Two (2) canisters are placed in each CWP-2 container, and welding equipment installed in MPPF performs seal welding of the CwP-2s.

- A Helium atmosphere is provided internal to the CwP-2s, and leak testing is performed.

- The CwP-2s provide a primary containment

- MPPF equipment is utilized to store the CWP-2s in the MPPF cell until ready for shipment to ORNL.

- Existing canyon functions and equipment will be available (e.g., crane, decon cell, railroad tunnel, air locks, etc.).

- Outside the F-Canyon building, the off-site shipping cask will be decontaminated, off-loaded from the rail car, and loaded onto the flatbed truck.

- The off-site transport cask into which the CwP-2s are placed is qualified as a secondary containment for shipment.

- ORNL receives the Off-site shipping cask, unloads and stores the CwP-2s as a unit while returning the off-site shipping cask to SRS. 
Appendix I

Schedule

- Glass production of $\mathrm{Am} / \mathrm{Cm}$ to start 7/01 and end between 1/02 to 3/02 (basis: Current Planning Agreements)

- Deactivation of the F-Canyon will start on 10/1/02. In order not to affect D\&D of the F-Canyon, the goal is to remove all the $\mathrm{Am} / \mathrm{Cm}$ materials (glass canisters) from F-Canyon as soon as possible.

- Round trip for off-site canisters to ORNL and back to F-Canyon is about2 weeks

- ORNL to receive all shipments (including Mark 18s) by 2006.

Rates

- Canister production to be 25 per month. (As:suming 200 canisters produced from 7/01 to 3/02).

$$
\text { Cost }
$$

- R\&D, Project, Operation/Maintenance costs (no D\&D) to place canisters/carriers into racks -- $\$ 80 \mathrm{M}$

- Design and installation of welder -- $\$ 1.3 \mathrm{M}$

- Operational cost of F-Canyon not included - Ongoing operation.

- The qualification, approval, and licensing of a double containment cask (if necessary) for shipment of Am/Cm canisters to ORNL -- $\$ 1.5 \mathrm{M}$

- The acquisition of a double containment casik (if necessary) for shipment of Am/Cm canisters to ORNL -- $\$ 3.0 \mathrm{M}$

- Shipment to ORNL -- $\$ 1.2 \mathrm{M}-\$ 2 \mathrm{M}$

- Design and installation of storage space at ORNL -- \$7M

- Operational cost at ORNL not included -- Ongoing operation.

Issues

- Establish if off-site shipment of Am/Cm materials to ORNL requires a single or double containment cask. Containment requirements depend on package plutonium contents (up to 20 Curies of plutonium can be shipped in a single containment package).

- Decontamination performed at F-Canyon may require an additional enclosure (building) due to weather

- Addition of another railroad spur may be required depending on F-canyon schedule impact.

Enabling Objectives

- Obtain funding for further process and equipment development

- Complete R\&D project on schedule

- Design and install welder in $\mathrm{F}$ Canyon

- Add storage area to ORNL

- Fund operation of $F$ Canyon systems required to support $\mathrm{Am} / \mathrm{Cm}$ disposition.

\subsubsection{Function: - Make Glass - Tank 17.1 Solution Disposition - Alternative Three}

See Function 9.9.1.1-Tank 17.1 Solution Disposition - Base Case

\subsubsection{Function: Weld glass canister(s) in CwP-2 - Tank 17.1 Solution Disposition - Alternative Three}

See Function 9.9.1.2 - Weld the glass cianister(s) in the CwP-1s - Base Case

Exception:

Sub-functions

- Seal weld the CwP-2

Cost

- Welder installation -- $\$ 1.3 \mathrm{M}$ 
Appendix 1

\subsubsection{Function - Store the in F Canyon - Tank 17.1 Solution Disposition - Alternative Three}

See Function 9.9.3.3 - Store in F Canyon - Tank 17.1 Solution Disposition -Alternative Two Exception:

Sub-functions

- Place CWP-2 carriers in lag storage rack in MPPF.

\subsubsection{Function - Ship to ORNL via F-Canyon - Tank 17.1 Solution Disposition - Alternative Three}

Sub-functions:

- Stage off-site cask for shipping.

- Transfer Truck Cask to Rail Car.

- Move Loaded Rail Car into F-Canyon Railroad Tunnel

- Leak Test CwP-2s

- Move Carriers with CwP-2s out of MPPF and decontaminate at F-Canyon Decontamination Station.

- Load CwP-2s into Cask.

- Move Rail Car with Loaded Cask out of F-Canyon

- Transfer Cask from Rail Car to Truck Flat Bed and prepare for shipment.

Requirements:

- Leak Test the CwP-2s. To meet "Special Shipment" the vessel qualified as a "containment vessel", must be leaked tested within one year of shipment.

- Shipping package has to meet U.S. Department of Transportation, Title 49, CFR Parts 100 through 189, DOE Order 5480.3, and NRC Regulations, Title 10, CFR, Part 71

- The loading of the off-site shipping cask is to be remotely controlled.

- A cradle must be provided to prevent cask tip over during up ending operation.

- Crane(s) shall be capable of horizontal cask movement and up ending.

- The capability to attach rigging and chokers as well as bolt removal and torgue (including but not limited to cask top bolts) shall be provided.

- Cask wash down, pressurization and leak testing capabilities shall be available in F Canyon railroad tunnel.

- Decontaminate casks to $2,200 \mathrm{dpm} / 100 \mathrm{~cm}^{2}$ (Beta Gamma), TBD (Alpha), to qualify for Off-Site Shipment.

- The off-site shipping cask will have to satisty: (a) Shielding requirements; (b) Containment requirements; and (c) Heat generation rate.

- The CwP-2s and associated pintle are to be centered in the shipping sleeve for retrieval by ORNL equipment.

- Rigging and chokers must be provided

Interfaces

- ORNL facility, equipment and schedule

- NRC \& DOT - Shipping Cask Qualification

Issues

- It is not clear if the off-site shipping cask (package) for $\mathrm{Am} / \mathrm{Cm}$ canisters will require double or single containment. Containment requirements depend on package plutonium contents (up to 20 Curies of plutonium can be shipped in a single containment package). The plutonium content of the canisters is not known at this stage. Single containment casks are generally available and can be leased. However, double containment casks are not readily available. 


\section{Appendix I}

The qualification, licensing, and accuisition of a double containment cask for shipment of $\mathrm{Am} / \mathrm{Cm}$ materials may cost $\$ 4.5 \mathrm{M}$, and may take 3 to 5 years.

- The number of canisters that can bel loaded in a single cask also depends on shielding considerations. The $A \mathrm{~m} / \mathrm{Cm}$ canisters are highly radioactive, and loading too many canisters in a single cask may result in excessive dose rates around the cask. The acceptable number for a particular cask will have to be established by analysis.

- The ORNL receiving requirements and acceptable CWP-2s requirements are not firm.

- It may take up to two weeks to decontaminate the CWP-1s and to load the off-site cask.

\section{Assumptions}

- Cask certified for transportation of $A \cdot \mathrm{m} / \mathrm{Cm}$ canisters is obtained. This may include the leasing of an existing cask or the certification of a new cask.

- Prepare Safety Analysis Report for off-site shipping package (SARP), and obtain approval from DOT is complete.

- ORNL has new storage room available and equipment and personnel are ready for receipt.

- It is assumed that $\mathrm{Am} / \mathrm{Cm}$ operations will not interfere with $\mathrm{D \& D}$.

- Current 50 Ton crane will have adequate capacity

- All operations for decontamination and cask handling may be performed with the existing crane and facilities with minor modification.

Schedule

- One full day is required for F Canyon to prepare the cask for loading.

- Two full days are required to prepare a cask for shipment.

Cost

- The qualification and approval, of al double containment cask (if necessary) for shipment of Am/Cm canisters to ORNL -- \$1.5M

- Shipment to ORNL -- $\$ 1.2 \mathrm{M}-\$ 2 \mathrm{M}$

\subsubsection{Function - Store material at ORNL- Tank 17.1 Solution Disposition - Alternative Three}

See Function 9.9.1.6 - Store material at ORNL - Base Case 
WESTINGHOUSE SAVANNAH RIVER COMPANY

Americium/Currium Disposition Life Cycle Planning Study(U)

Appendix 1

\subsubsection{Tank 17.1 “Solution” Disposition - Alternative Four - Interim Dry Cask Storage}

Flow chart: Tank 17.1 Solution- Interim Dry Cask Storage

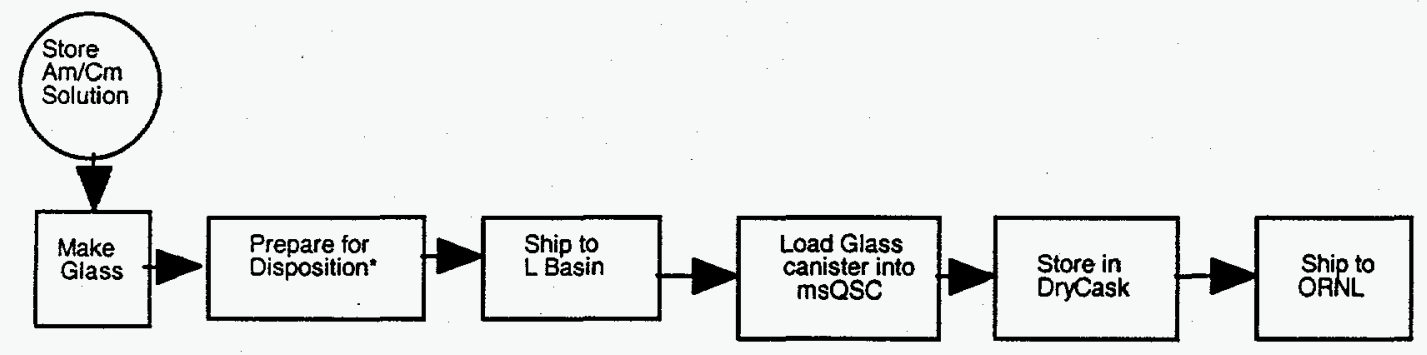

The Tank 17.1 "Solution" waste case begins with Tank 17.1 Solution stored in F-Canyon Tank 17-1. The solution is pretreated to remove transition metals such as $\mathrm{Cr}, \mathrm{Ni}$, and $\mathrm{Fe}$ and transferred to a feed tank in the Multi-Purpose Processing Facility (MPPF) for the vitrification process. Vitrification is a batch feed process at the end of which the molten glass drains from the melter into a "canister. The canister is sealed but does not provide a containment boundary. After being loaded into a carrier the canisters are lag stored in the MPPF. The canisters are retrieved from lag storage in the MPPF, seal welded into an contamination control canister (CWP-2) (Appendix H, section 9.8.2 Figure 2.2), and returned to MPPF for lag storage until L-Basin is ready to receive. The CwP-2 will be transferred by onsite shipping cask from F-Canyon to L-Basin. In L-Basin the CwP-2 will be loaded into an msQSC, provided with a Helium atmosphere, sealed, dry stored and finally transported to ORNL. For the Purpose of this document, all alternate means of accomplishing the end state of storage at ORNL emanate from the base case glass production in Section 6.7.1.

Premise : Tank 17.1 Solution Disposition - Alternative Four

- The Am/Cm in solution/slurry is immobilized by vitrification.

- Any Tank 17.1 Solution case may be utilized.

- Existing canyon functions and equipment will be available (e.g., crane, decon cell, railroad tunnel, air locks, etc.).

- Decontamination of the onsite shipping cask prior to leaving F-Canyon is minimal (i.e., wipe down)

- Decontamination and shipment activities within F-Canyon do not impact other F-Canyon operations and/or schedules.

- Once in L-Basin the CwP -2 will be loaded into and SNF canister and dry stored until ready for shipment to ORNL.

- Dry Spent Fuel Storage will be created at L Reactor

Primary functions - Tank 17.1 Solution Disposition - Alternative Four

9.9.5.1 Make Glass

9.9.5.2 Weld the glass canister(s) in CWP-2(s)

9.9.5.3 Store the CWP-2s in F-Canyon

9.9.5.4 Ship to $L$ Basin via F-Canyon

9.9.5.5 Load CWP-2 into MsQSC

9.9.5.6 Store msQSC at L Reactor (Dry Storage)

9.9.5.7 Ship To ORNL

9.9.5.8 Store at ORNL 


\section{Appendix I}

Schedule

- All Am/Cm and PU solutions to be out of canyon by year 2002 .

- Glass production of $\mathrm{Am} / \mathrm{Cm}$ to start 7/01 and end between 1/02 to 3/02 (basis: Current Planning Agreements)

- Mk 18 glass production to start $1 / 02$ to $3 / 02$ and finish $7 / 02$ to $9 / 02$

- ORNL to receive all shipments including Mark 18 s by 2006

\section{Rates}

- Canister production to be 25 per month. (Assuming 200 canisters produced from $7 / 01$ to $3 / 02$ ).

Issues

- Decontamination performed at F-Canyon may require an additional enclosure (building) due to weather

- Addition of another railroad spur may be required depending on F-canyon schedule impact.

Enabling Objectives

- Obtain funding for further process and equipment development

- Complete R\&D project on schedule

- Design and install welder in F-Canyon

- Obtain NEPA coverage for storage in L Basin and msQSC storage casks

- Add storage area to ORNL

- Fund operation of $F$ Canyon systems required to support $\mathrm{Am} / \mathrm{Cm}$ disposition.

Cost

- R\&D, Project, Op/Maint costs (no D\&D) to place canisters/carriers into racks. - $\$ 80 \mathrm{M}$

- Design and installation of welder. - $\$ 1.3 \mathrm{M}$

- Operational cost of F Canyon not included - Ongoing operation.

- On site shipment \$150K - \$100K

- Cost of msQSCs -- \$90-130K

- Dry storage of $30-58 \mathrm{msQSCs}-\$ 1.3-\$ 1.7 \mathrm{M}$

- The qualification and approval, of a double containment cask (if necessary) for shipment of $\mathrm{Am} / \mathrm{Cm}$ canisters to ORNL -- $\$ 1.5 \mathrm{M}$

- The acquisition of a double containment cask (if necessary) for shipment of Am/Cm canisters to ORNL -- \$3.0M

- Design and installation of storage space at ORNL $-\$ 7 M$

- Operational cost of ORNL not included * Ongoing operation.

- Shipment to ORNL -. $\$ 1.2 \mathrm{M}-\$ 2 \mathrm{M}$

\subsubsection{Fuñction: Make Glass - Tank 17.1 Solution Disposition - Alternative Four}

See Tank 17.1 Solution - Base Case Function 9.9.1.1

\subsubsection{Function: Weld the glass canister(s) in the CWP-2 - Tank 17.1 Solution Disposition - Alternative Four}

See Tank 17.1 Solution Alternative Three Function 9.9.4.2 
Appendix 1

9.9.5.3. Function: Store the CWP-2s in F-Canyon - Tank 17.1 Solution Disposition - Alternative Four See Tank 17.1 Solution Alternative Three Function 9.9.4.3

Exception: $\quad$ Schedule- Store until $L$ Basin is ready to receive

\subsubsection{Function: Ship to L Basin via F-Canyon - Tank 17.1 Solution Disposition - Alternative Four}

See Tank 17.1 Solution Alternative Three Function 9.9.4.4

Exceptions:

Interfaces

- L Basin Schedule

Schedule

- Start transfer to L Basin in October 2001

\subsubsection{Function: Load CWP-2 into msQSC - Tank 17.1 Solution Disposition - Alternative Four}

Sub-Functions

- Load CwP-2 into msQSC

- Dry msQSC

- Backfill msQSC with helium

- Seal msQSC

- Leak test

- Decontaminate msQSC

Requirements

- Loaded msQSC must meet criteria for dry storage.

Interfaces

- New SNF packaging function schedule

- New SNF packaging equipment

Issues

- Equipment and method for handling msQSC has not been analyzed

Assumptions

- The handling of msQSCs versus SNF canisters does not create significant impact

Schēdule

- Earliest available date for starting to de-inventory glass from $L$ Basin is after reduction of receipts, about 2010.

- Latest de-inventory of glass after SNF de-inventories from L Basin about 2013.

Cost

- Operations cost is within envelope of new SNF packaging facility costs

9.9.5.6. Function: Store containers at L Reactor (Dry Storage) - Tank 17.1 Solution Disposition Alternative Four

Sub-functions

- Load msQSCs into transfer cask 
WESTINGHOUSE SAVANNAH RIVER COMPANY

Americium/Curium Disposition Life Cycle Planning Study(U)
Document: NMP.PLS-980044

Revision 0

April 30, 1998

Page 86 of 159

\section{A.ppendix I}

- Transfer cask from L Reactor to Stolage Pad

- Load msQSC into concrete storage cask 


\section{Appendix I}

Requirements

- msQSC must meet dry storage head and radiation (field) requirements

- msQSC must meet transfer radiation requirements

Interfaces

- Transfer Cask

- Storage Cask

Issues

- Radiation field from msQSC canister

- Compatibility of msQSC with spent fuel handling equipment

Assumptions

- msQSCs loaded six to a cask

Schedule

- Glass canisters will be loaded into storage canisters between 2006 and 2013.

Cost

- Concrete storage casks cost \$400K. For 38-50 msQSCs -- \$1.3-1.7M

- Movement costs are within the operational costs of the SNF packaging and storage activity.

\subsubsection{Function: Ship to ORNL - Tank 17.1 Solution Disposition - Alternative Four}

See Tank 17.1 Solution Disposition - Base Case- Function 9.9.1.5

\subsubsection{Function: Store at ORNL - Tank 17.1 Solution Disposition - Alternative Four}

See Tank 17.1 Solution Disposition - Base Case- Function 9.9.1.6 
WESTINGHOUSE SAVANNAH RIVER COMPANY

Americium/Curium Disposition Life Cycle Planning Study(U)
Document: NMP-PLS-980044

Revision 0

April 30, 1998

Page 88 of 159

Appendix I

\subsubsection{Tank 17-1 "Solution" Disposition - Alternative Five: Treat Glass as Waste}

Flow chart: Tank 17.1 Solution Disposition - Waste Case

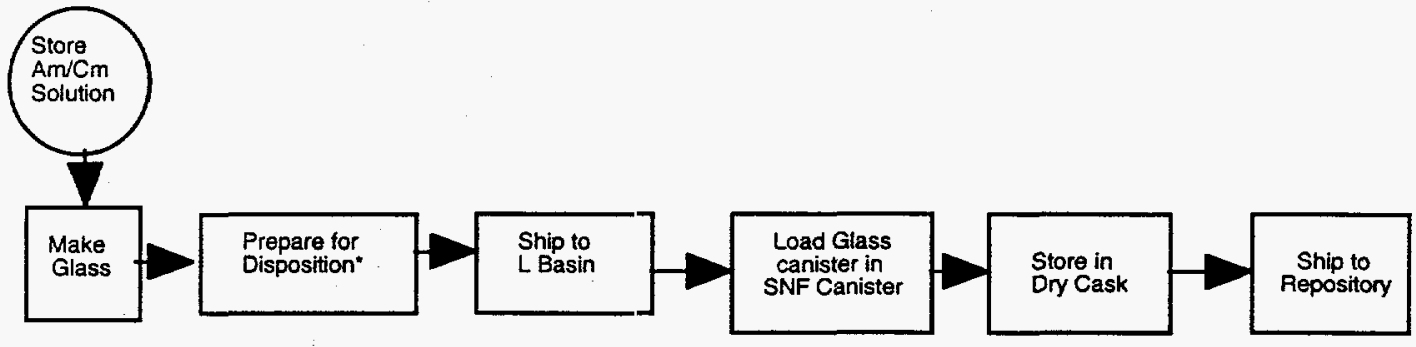

The Tank 17.1 "Solution" waste case begins with Tank 17.1 Solution stored in F-Canyon Tank 17-1. The solution is pretreated with oxalic acid to remove transition metals, such as $\mathrm{Cr}, \mathrm{Ni}$, and $\mathrm{Fe}$ and transferred to a feed tank in the Multi-Purpose Processing Facility (MPPF) for the vitrification process. Vitrification is a batch feed process at the end of which the molten glass drains from the melter into a "canister. The canister is sealed but does not provide a containnent boundary. After being loaded into a carrier the canisters are lag stored in the MPPF. The canisters are retrieved from lag storage in the MPPF, seal welded into an contamination control canister (CwP-2) (Appendix H, section 9.8.2 Figure 2.2), and returned to MPPF for lag storage until L-Basin is ready to receive. The CwP-2 will be transferred by onsite shipping cask from F-Canyon to L-Basin. In L-Basin the CWP-2 will be loaded into a Spent Nuclear Fuel canister, provided with a Helium atmosphere, sealed, lag stored ancl finally transported to the repository. (MGDS). For the Purpose of this document, all alternate means of accomplishing the end state of disposal at the MGDS emanate from the base case glass production in Section 6.7.1.

Premise : Tank 17.1 Solution Disposition - Alternative Four

- The Am/Cm in solution/slurry is immobilized thy vitrification.

- Any Tank 17.1 Solution case may be utilized.

- Existing canyon functions and equipment will be available (e.g., crane, decon cell, railroad tunnel, air locks, etc.).

- Decontamination of the onsite shipping cask prior to leaving F-Canyon is minimal (i.e., wipe down)

- Decontamination and shipment activities with in F-Canyon do not impact other F-Canyon operations and/or schedules.

- Once in L-Basin the CWP-2s will be loaded into and SNF canister and dry stored until ready for shipment to ORNL.

Primary functions - Tank 17.1 Solution Disposition - Alternative Five

9.9.6.1 Make glass

9.9.6.2 Weld the glass canister(s) in CWP-2(s)

9.9.6.3 Store the CWP-2s in F-Canyon

9.9.6.4 Ship to L Basin via F-Canyon

9.9.6.5 Load CWP-2s into SNF Canister

9.9.6.6 Store containers at L Reactor (Dry Stcrage)

9.9.6.7 Ship containers to Repository (MGDS)

Schedule

- All Am/Cm and PU solutions to be out of canyon by year 2002.

- Glass production of $\mathrm{Am} / \mathrm{Cm}$ to start 7/01 and end between 1/02 to 3/02 (basis: Current Planning Agreements)

- Mk 18 glass production to start $1 / 02$ to $3 / 02$ and finish $7 / 02$ to $9 / 02$

- ORNL to receive all shipments including Mal'k 18 s by 2006 


\section{Appendix 1}

\section{Rates}

- Canister production to be 25 per month. (Assuming 200 canisters produced from 7/01 to 3/02).

Issues

- Decontamination performed at F-Canyon may require an additional enclosure (building) due to weather

- Addition of another railroad spur may be required depending on F-canyon schedule impact.

\section{Enabling Objectives}

- Obtain funding for further process and equipment development

- Complete R\&D project on schedule

- Design and install welder in F-Canyon

- Obtain NEPA coverage for storage in L Basin and dry spent fuel storage casks

- Obtain funding to qualify glass for the repository

- Fund operation of F Canyon systems required to support Am/Cm disposition.

Cost

- R\&D, Project, Op/Maint costs (no D\&D) to place canisters/carriers into racks. - $\$ 80 \mathrm{M}$

- Design and installation of welder. - $\$ 1.3 \mathrm{M}$

- Operational cost of $F$ Canyon not included - Ongoing operation.

- Ship to L Basin -- \$150K - \$300K

- SNF canister -- $\$ 0.5 \mathrm{M}-\$ 0.8 \mathrm{M}$

- Dry Cask Storage -- \$2.5-3.4M

- Repository Shipment -- $\$ 0.4 \mathrm{M}-\$ 0.5 \mathrm{M}$

- Repository emplacement -- $\$ 2.4-3.3 \mathrm{M}$

- Glass Qualification for repository -- $\$ 10 \mathrm{M}-\$ 50 \mathrm{M}$

\subsubsection{Function: Make Glass - Tank 17.1 Solution Disposition - Alternative Five}

See Tank 17.1 Solution - Base Case Function 9.9.1.1

\subsubsection{Function: Weld the glass canister(s) in the CWP-2 - Tank 17.1 Solution Disposition - Alternative Five}

\section{See Tank 17.1 Solution Alternative Three Function 9.9.4.2}

\subsubsection{Function: Store the CWP-2s in F-Canyon - Tank 17.1 Solution Disposition - Alternative Five}

See Tank 17.1 Solution Alternative Three Function 9.9.4.3

Exception:

Schedule-

- Store until L Basin is ready to receive

\subsubsection{Function: Ship to L Basin via F-Canyon - Tank 17.1 Solution Disposition - Alternative Five}

See Tank 17.1 Solution Alternative Three Function 9.9.4.4

Exceptions:

Interfaces

- L Basin Schedule 


\section{Appendix I}

\subsubsection{Function: Load CWP-2s into SNF Canister - Tank 17.1 Solution Disposition - Alternative Five}

Sub-Functions

- Load CwP-2 into SNF canister

- Put lid on canister

- Dry canister

- Backfill canister with helium

- Seal canister

- Leak test canister

- Decontaminate canister

Requirements

- Loaded canister must meet criteria "or dry storage.

Interfaces

- New SNF packaging function schedule

- New SNF packaging equipment

Issues

- Acceptability of SNF canister for Am/Cm glass storage, transportation, and emplacement in the MGDS.

- Acceptability of SNF glass

- Glass packaging in SNF canister has not been designed (needs spider)

\section{Assumptions}

- Three CwP-2s can be loaded per sprent fuel canister -- e.g., 15 to twenty total canisters would be needed.

\section{Schedule}

- Earliest available date for starting to de-inventory glass from $L$ Basin is after reduction of receipts, about 2010.

- Latest de-inventory of glass after SNF de-inventories from L Basin about 2013.

Cost

- Canister cost is approximately $\$ 20 \mathrm{~K}$

- Operations cost is within envelope of new SNF packaging facility costs

\subsubsection{Function: Store containers at L Reactor (Dry Storage) - Tank 17.1 Solution Disposition - Alternative Five}

Sub-functions

- Load SNF canister into transfer cask

- Transfer cask from L Reactor to Storage Pad

- Load SNF canister into concrete storage cask

Requirements

- Canister must meet dry storage head and radiation (field) requirements

- Canister must meet transfer radiation requirements 


\section{Interfaces}

\section{Appendix I}

- SNF Transfer Cask

- SNF Storage Cask

Issues

- Radiation field from SNF canister

- Compatibility of SNF canister with Am/Cm glass with spent fuel canisters

Assumptions

- SNF canisters are loaded six to a cask

- $A m / C m$ glass canisters are compatible with SNF transfer cask

- $\mathrm{Am} / \mathrm{Cm}$ glass canisters are compatible with SNF canisters when loaded in storage cask

Schedule

- Glass canisters will be loaded into storage canisters between 2006 and 2013.

Cost

- Concrete storage casks cost $\$ 400 \mathrm{~K}$. Total -- $\$ 2.5 \mathrm{M}-\$ 3.4 \mathrm{M}$

- Movement costs are within the operational costs of the SNF packaging and storage activity.

\subsubsection{Function: Ship containers to Repository (MGDS) - Tank 17.1 Solution Disposition - Alternative Five}

Sub-functions

- Load SNF glass canisters in transport cask

- Rail ship transport cask to MGDS

- Unload canister at MGDS above ground facilities

- Place canister in co-disposal overpack in the MGDS

Requirements

- Fissile and radionuclide curie contents will need to be know for each canister

Interfaces

- MGDS EIS

- MGDS Waste Acceptance Criteria

- MGDS Transportation System

- Dry Spent Fuel Storage

Issues

- Acceptability of Glass in SNF canister for shipment and emplacement

\section{Assumptions}

- Shipment is at seven canisters per cask

- Glass in SNF canisters is loaded in the center of a co-disposal overpack

Schedule

- Glass will ship to MGDS after it opens estimated in about 2015

$\underline{\text { Cost }}$

- Transportation cost is $\$ 504 \mathrm{~K}$ for a five car dedicated train, each cask containing seven SNF canisters -- \$400-500K

- MGDS Emplacement cost is $\$ 580 \mathrm{~K}$ for a co-disposal overpack containing $5 \mathrm{HLW}$ canisters and one SNF canister $-\$ 2.4-3.3 \mathrm{M}$ 


\section{A.ppendix 1}

\subsection{7. "Mark 18s" Disposition - Base Alternative}

Flow chart: Mark 18 Disposition - Base Alternative

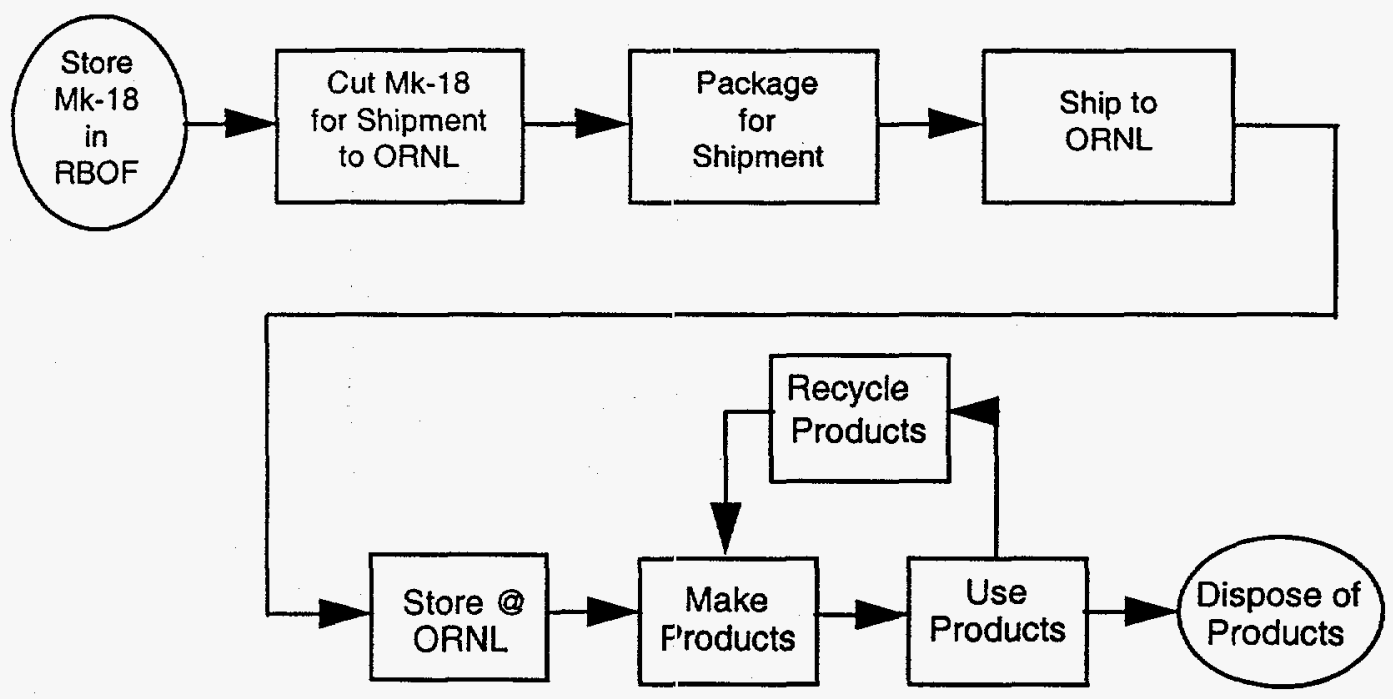

The base case for the Americium and Curium Target (MK 18) disposition begins with Mk 18s stored in RBOF and finishes at ORNL. For the Purpcise of this document, all alternate means of accomplishing the end state of use at ORNL emanate from this base case. From the point the material leaves SRS the functional description remains the same for all alternative cases.

Planning level estimated total life-cycle cost $=\$ 17 \mathrm{M}$

$$
=\$ O M \text { (existing program) + \$17M (SRS) + \$OM (ORNL, covered by other program) }
$$

\section{Premise : Mark 18 Disposition - Base Alternative}

- All operations are performed in the RBOF basin.

- The Mk $18 \mathrm{~s}$ provide primary containment for radionuclides.

- The shipping package is mechanically sealecl with two Mk 18 s per package

- A Helium atmosphere is provided internal to the package.

- Secondary waste stream impacts are minimal and not analyzed.

- Existing RBOF equipment is utilized to load the package into the On-site shipping cask.

- RBOF decontaminates a qualified Off-site shipping cask for transport to ORNL

- The off-site transport cask into which the package is placed is qualified as a secondary containment for shipment.

- ORNL receives the Off-site shipping cask, unloads and stores the package as a unit while returning the off-site shipping cask to SRS.

Primary functions - Mark 18 Disposition - Base Alternative

\subsubsection{Cut ends off Mk 18s}

9.9.7.2 Load Mk $18 \mathrm{Mk} 18 \mathrm{~s}$ in the package for shipment

9.9.7.3 Ship to ORNL via RBOF

9.9.7.4 Store material at ORNL 


\section{Appendix 1}

Schedule

- Mk 18 Mk 18 s to be removed from RBOF by year 2003.

- Packaging of Mk 18 s to start 3/00 and be completed by 7/02.

- Round trip for off-site canisters to ORNL and back to RBOF $\approx 2$ weeks

- ORNL to receive all shipments including Mark 18 s by 2006

Rates

- 33 packages of two Mk 18s each produced between 3/00 and 7/02

$\underline{\text { Cost }}$

- Design, equipment and packaging efforts in RBOF -- $\$ 15 \mathrm{M}$

- The qualification and approval, of a double containment cask (if necessary) for shipment of Am/ $\mathrm{Cm}$ canisters to ORNL -- $\$ 1.5 \mathrm{M}$ (Not included)

- The acquisition of a double containment cask (if necessary) for shipment of $\mathrm{Am} / \mathrm{Cm}$ canisters to ORNL -- \$3.0M. (Not included)

- $\quad$ Shipment to ORNL - \$2M

- Operational cost of ORNL not included - Ongoing operation.

- Design and installation of storage space and equipment modifications at ORNL - \$3M

$\underline{\text { Issues }}$

- Mark 18 s may be brittle, they were irradiated for $\sim 10$ years in a high flux atmosphere and have been stored under water for 10 years. If cut or handled they may break up.

- $\quad$ Shipment awaits storage availability from Mark 42 processing

\section{Enabling Objectives}

- Obtain funding for further process and equipment development

- $\quad$ Complete R\&D project on schedule

- Install appropriate tanks and jumpers in F Canyon to support MK 18 dissolution

- Design and install welder in $\mathrm{F}$ Canyon

- Design and licensing of a containment cask for shipment of Am/Cm to ORNL

- $\quad$ Add storage area to ORNL

- $\quad$ Fund operation of $\mathrm{F}$ Canyon systems required to support $\mathrm{Am} / \mathrm{Cm}$ disposition.

\subsubsection{Function: Cut ends of Mk 18s - Mark 18 Disposition - Base Alternative}

\section{Sub-Functions:}

- Cut top off storage bundle

- Move Mk 18 to cutting station

- Determine cut locations base on gamma activity

- Cut off ends

Requirements:

- Cutting shall not fracture or deform the Mk 18

- Mk 18 shall be cut into 20 " segments

Interfaces:

- RBOF equipment including new gamma measurement/positioning/cutting system

- Shipping can

Issues:

- Release of radio-nuclides to RBOF basin and air 


\section{Appendix I}

- Failure of target when shipped, causing material to concentrate and exceed allowable shipping dose rates

- Brittleness of Mk 18's

- USQD for Mk 18 cutting operations

- Technical maturity of cutting equipment (R\&D)

- NEPA evaluation required

Assumptions

- Mk 18s can be cut without release or fracture/deformation problems

Schedule

- Operations start 3/00 and end 7/02.

Cost

- Design and packaging cost $\$ 15 \mathrm{M}$

\subsubsection{Function: Load Mk 18s in the package for shipment - Mark 18 Disposition - Base Alternative}

Sub-functions:

- Determine Mk 18 integrity

- Load can

- Blow out can; backfill with helium

- Seal Can

- Leak test can

Requirements:

- Fuel shall not be breached

- Cans shall meet leak rate requirements (TBD)

Interfaces:

- RBOF equipment including new integrity measuring and leak test equipment

- NLI 1/2 or NAC LWT casks

Issues:

- Disposition of breached fuel

- Technical maturity of integrity measurement equipment

- NEPA evaluation

Assumptions:

- None

Schedule:

- Operations start 3/00 and end 7/02.

Cost:

- Included in the function above

\subsubsection{Function: Ship to ORNL via RBOF - Mark 18 Disposition - Base Alternative}


WESTINGHOUSE SAVANNAH RIVER COMPANY

Americium/Curium Disposition Life Cycle Planning Study(U)
Document: NMP-PLS-980044

Revision 0

April 30, 1998

Page 95 of 159

\section{Appendix I}

\subsubsection{Function: Store material at ORNL - Mark 18 Disposition - Base Alternative}

See Tank 17.1 Solution Base Case Function 9.9.1.6 except:

Cost:

- Estimated cost of $\$ 2 \mathrm{M}$ to modify storage for cut Mark $18 \mathrm{~s}$ plus equipment modifications to handle longer tubes estimated at $\$ 1 \mathrm{M}$ Total $--\$ 3 M$ 


\section{Appendix 1}

\subsection{8. "Mark 18s" Disposition - Alternative: One Review}

Flow chart: Mark 18 Disposition - Alternative One
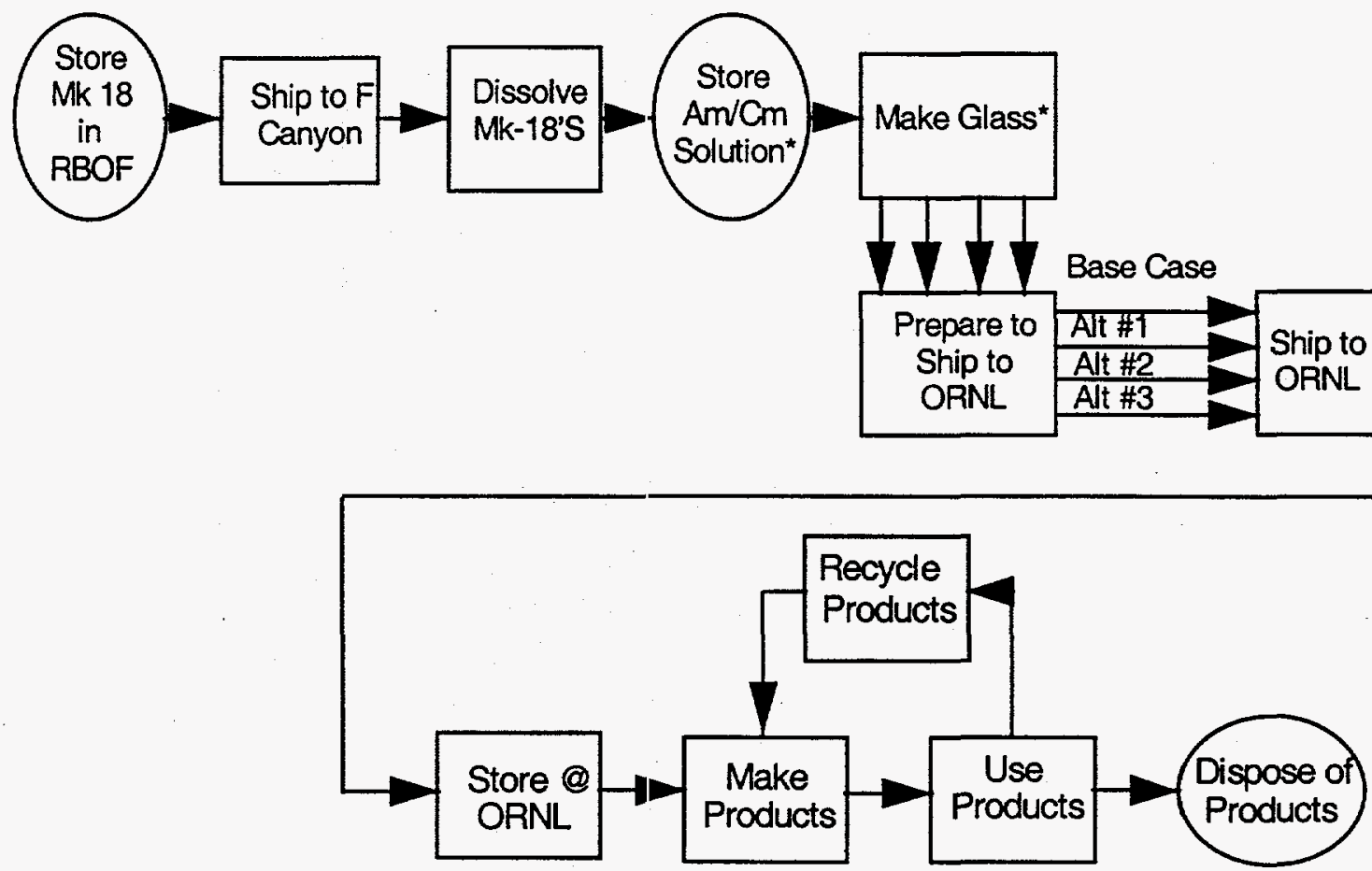

*Note: Glass functions not analyzed

Alternative one for Americium and Curium target (Mk 18) disposition begins with Mk 18s stored in RBOF and finishes at ORNL. For the Purpose of this document, all alternate means of accomplishing the end state of use at ORNL emanate from the base case glass production in Section 6.7.1 and may follow any of the base or alternatives shown. Additionally, as in previous glass cases, from the point the material SRS the functional description remains the same for all alternative cases.

Planning level estimated total life-cycle cost $=\$ 7.6 \mathrm{M}$

$=\$ O M$ (existing program) + \$7.1-8.1M (SRS) - \$1M (ORNL, reduced costs from not having waste stream associated with removal of $\mathrm{Al}$ )

Premise: Mark 18 Disposition - Alternative One

- All Mk $18 \mathrm{~s}$ are brought to F Canyon for processing.

- All operations are remotely controlled

- The Mk 18s dissolved and stored in F Canyon

- The Am/Cm in solution (slurry) is immobilized by vitrification.

- The glass form is seal welded (for decontamination Purposes) into stainless steel canisters.

- The glass form (canisters) provides no containment function and must have a qualified primary and secondary containment for shipping.

- The "best" case for Tank 17.1 Solution will be used for Mk 18 glass packaging.

- NOTE: The glass path from solution to ORNL should one of the alternative cases shown in Sections 6.7.1, 6.7.2, 6.7.3, 6.7.4 or 6.7.5. 


\section{Appendix I}

- ORNL receives the Off-site shipping cask, unloads and stores the MK 18 glass package as a unit while returning the off-site shipping cask to SRS.

- The off-site shipping cask into which the CWP-1s are placed is qualified as a secondary containment for shipment.

Primary functions - Mark 18 Disposition - Alternative One

9.9.8.1 Ship Mk 18s to F Canyon

9.9.8.2 Dissolve Mk 18s

9.9.8.3 Store Mk 18 slurry

9.9.8.4 Make glass *

9.9.8.5 Prepare glass to ship to ORNL**

9.9.8.6 Ship to ORNL**

9.9.8.7 Store material at ORNL

- Note: The "best" technique for preparing Tank 17.1 Solution for shipment will also be used for Mk 18 glass. ** Note: These sub-functions recapitulate the appropriate functions for preparing $\mathrm{Am} / \mathrm{Cm}$ glass to ship to ORNL and shipping shown in the base case and alternatives.

\section{Schedule}

- Mk 18 glass production to start $1 / 02$ to $3 / 02$ and finish $7 / 02$ to $9 / 02$

- Round trip for off-site canisters to ORNL and back to RBOF $\approx 2$ weeks

- ORNL to receive all shipments by 2006

Rates

- $65 \mathrm{Mk} 18 \mathrm{~s}$ shipped to $\mathrm{F}$ Canyon before dissolution. Estimated dissolution time is 6 months.

- $50 \mathrm{Mk} 18$ glass canisters in appropriate packaging will need shipping (7 shipments at 8 canisters/shipment).

Cost

The following would be covered by the "solution" to glass program

- R\&D, Project, Op/Maint costs (no D\&D) to place canisters/carriers into racks. - $\$ 80 M$ (existing program)

- Design and installation of welder.

- Operational cost of F Canyon and RBOF not included - Ongoing operation

- The qualification and approval, of a double containment cask (if necessary) for shipment of $\mathrm{Am} / \mathrm{Cm}$ canisters to ORNL -- \$1.5M

- The acquisition of a double containment cask (if necessary) for shipment of Am/Cm canisters to ORNL -- \$3.0M.

- Design and installation of storage space at ORNL - $\$ 7 \mathrm{M}$

- Operational cost of ORNL not included - Ongoing operation.

The following would be increased costs from processing the Mk 18s @ SRS rather then ORNL

- Ship from RBOF to F Canyon -- $\$ 200 \mathrm{~K}$

- Design installation and startup of 17.3D dissolver and tankage - \$3-6M

- Make Glass - $\$ 1 \mathrm{M}$ to $\$ 2 \mathrm{M}$

- Shipment to ORNL, 50 canisters $\$ 420 \mathrm{~K}$

Enabling Objectives

- Obtain funding for further process and equipment development

- Complete R\&D project on schedule

- Install appropriate tanks and jumpers in F Canyon to support Mk 18 dissolution

- Design and install welder in $F$ Canyon

- Add storage area to ORNL

- Funding for operation of $F$ Canyon systems required to support $\mathrm{Am} / \mathrm{Cm}$ disposition. 


\section{A.ppendix I}

\subsubsection{Function: Ship Mk 18s to F Canyon - Mark 18 Disposition - Alternative One - Appendix to Section 6.7 .8}

Sub-functions:

- Load CD cask

- Decontaminate CD Cask

- Transport CD Cask to F Canyon

Requirements:

- Casks shall be decontaminated to TBD surface levels beta/gamma/100 $\mathrm{cm}^{2}$ and TBD surface level alpha/ $100 \mathrm{~cm}^{2}$

- TBD Mk 18s can be shipped per shipment

Interfaces:

- RBOF equipment

- CD casks

- F Canyon fuel handling equipment

Issues:

- NEPA evaluation

Assumptions:

- Mk 18s can be transferred to F Canyon for processing in a timely way

- Mk 18 processing will not interfere will other Canyon activities

Schedule:

- Shipments start no latter then $1 / 02$ to $3 / 02$; shipments complete $5 / 01$

Costs:

- Costs are within normal operations of RBOF and F Canyon

\subsubsection{Function: Dissolve Mk 18 - Mark 18 Disposition - Alternative One}

\section{Sub-functions}

- Unload CD Cask

- Transfer Mk 18 s to 17.3 dissolver

- Remove Aluminum with $\mathrm{NaOH}$

- Decant sodium aluminate solution

- Treat off-gas stream

Requirements

- Americium and Curium shall remain with insoluble lanthanide hydroxides

- Feed concentration of sodium shall be below TBD.

- Feed shall be capable of making a durable glass

Interfaces:

- F Canyon equipment 


\section{Issues:}

\section{Appendix 1}

- Flowsheet has not been verified

- NEPA evaluation

- Compatibility of Mk 18 feed with the glass process

- The treatment of the added solution resulting from dissolving the Mark 18 , and vitrification of additional $\mathrm{Am} / \mathrm{Cm}$ materials will require that the operating life of pretreatment/vitrification equipment be extended.

\section{Assumptions:}

- Existing designs for Mk 18 dissolution system can be made compatible with present day requirements

- Tank $17.3 \mathrm{D}$ is still available

\section{Schedule:}

- Processing starts $1 / 02$ to $3 / 02$; processing complete $7 / 02$ to $9 / 02$

Cost:

- $\quad \$ 3-6 \mathrm{M}$ capital cost including tank modifications and jumpers

- Operating cost within cost of $F$ canyon operations

\subsubsection{Function: Store Mk 18 Slurry - Mark 18 Disposition - Alternative One}

Sub-functions:

- Hold Mk 18 lanthanide-actinide hydroxides

- Allow solution adjustments as necessary

\section{Requirements:}

- See Function 9.9.8.2 above

- Hold TBD feed for glass process

\section{Interfaces:}

- MPPF glass process

Issues:

- See Function 9.9.8.2 above

\section{Assumptions:}

- See Function 9.9.8.2 above

\section{Schedule:}

- See-Function 9.9.8.2 above

Cost:

- See Function 9.9.8.2 above 
WESTINGHOUSE SAVANNAH RIVER COMPANY

Americium/Curium Disposition Life Cycle Planning Study(U)
Document: NMP-PLS-980044

Revision 0

April 30, 1998

Page 100 of 159

Appendix I

\subsubsection{Function: Make Glass - Mark 18 Disprosition - Alternative One}

\section{Sub-Functions}

- Pretreat Mk 18 slurry as necessary

- Transfer solution to feed tank in Multi-P urpose Processing Facility (MPPF)

- Feed solution to melter and combine with flow of glass frit

- Charge melter \& Vitrify dissolved solids

- Treat off-gas stream

- Drain molten glass from bottom of melter into "canister"

- Seal "canister"

- Transfer sealed canister to "carrier"

- Transfer loaded carrier to "rack" and laç store

- Perform MC\&A (calorimeter measurement)

\section{Requirements:}

- Glass product shall be nitric acid soluble \{Only process available to ORNL\}

- Glass chemistry and canister size are to interface with ORNL. \{ORNL equipment will be used to handle canisters\}

- Glass shall be capable of being "broken up" into chunks [Enables increased surface exposure to nitric acid, which decreases the dissolution time. ORNL proposed process: cut open canister, drill vertically into glass, break up within canister, dump out of canister and crush glass chunks to further decrease size\}

- Dissolution time goal: 2 days or less per canister (If greater then two days costs begin to become very prohibitive\}

- During dissolution, silica shall drop out of solution and remain behind in dissolution vessel \{Silica creates problems if carried downstream in ORNL process\}

- Minimize potential RCRA issues, i.e. minimize lead content

- Operations are to be performed remotely and shall be encompassed under each facility Authorization Basis \{Minimize expected worker radiation exposure during operations\} Note: Verification of product recovery is being performed by WSRC-SRTC sending glass samples to ORNL for testing.

\section{Interfaces}

- MPPF equipment (manipulators, turntabiles, racks, crane, etc.) and new CWP-1 welder installation.

- ORNL chemical and equipment characteristics

\section{Issues:}

- Glass loading effects ability to vitrify

- Design and install canister seal/containrnent welder has not in the budget

- Method of sealing canister is TBD.

- F Canyon Authorization Basis does not deal with Mk 18 feed and may require USQD be performed to determine mitigating factors. Potential cost impact exists for mitigation factors.

- Making glass assumes an $80 \%$ reduction in Pu content. If less than $20 \mathrm{cu}$ may not stay that way. Short half life allows Pu $240 \& 241$ to creep back in from decay

- Technical Maturity of Americium/Curiumı vitrification process (R\&D)

\section{Assumptions:}

- It is assumed that the plutonium content per shipment exceeds 20 Curies. The amount of plutonium per shipment depends on a number of factors, these are: (a) The amount of plutonium removed during pretreatment; (b) The tolal number of glass canisters produced; and (c) The number of glass canisters per shipment. When the plutonium content per shipment exceeds 20 Curies the shipping package will have to incorporate a primary and secondary containment 


\section{Appendix I}

- A off-site shipping cask may be designed/modified that will accept the desired number of canisters without exceeding the casks radiation shielding requirements.

- Both of the above assumptions must take into account the total number of canisters to be produced. Currently the number of canisters is thought to be in the $150-200$ range.

- The allowable number of canisters per shipment based on Pu content is; a) 4.8 if 150 canisters are produced and b) 6.5 canisters if 200 canisters are produced. Refer to Appendix $\mathbf{G}$.

- Project rebaseline being performed 1st Qtq FY99, will conclude 80M is correct and will not be exceeded.

\section{Schedule}

- Operations will start take about six months.

Cost:

Overall Cost_- $80 \mathrm{M}$

- Includes all R\&D, Project, Op/Maint costs (no D\&D) to place canisters/carriers into racks

- Design and installation of the welder will add another $\$ 1.3 \mathrm{M}-\$ 1.7 \mathrm{M}$

\subsubsection{Function: Prepare glass to ship to ORNL - Mark 18 Disposition - Alternative One}

See function descriptions for Tank 17.1 Solution preparation of glass for shipment. Once the glass canister is poured the base or any the alternative Tank 17.1 Solution cases my be utilized.

\subsubsection{Function: Ship to ORNL-Mark 18 Disposition - Alternative One}

See Functions 9.9.1.1 or 9.9.1.2 for Am/Cm glass shipment to ORNL. Once the glass canister is poured the base or any alternative Tank 17.1 Solution case my be utilized.

\subsubsection{Function 7 - Store Material at ORNL - Mark 18 Disposition - Alternative One}

See Tank 17.1 Solution Base Case Function 9.9.1.6 


\section{Appendix 1}

\subsection{9. "Slugs/Other" Disposition - Base Alternative}

Flow chart: Slug/Other Disposition - Base Alternative

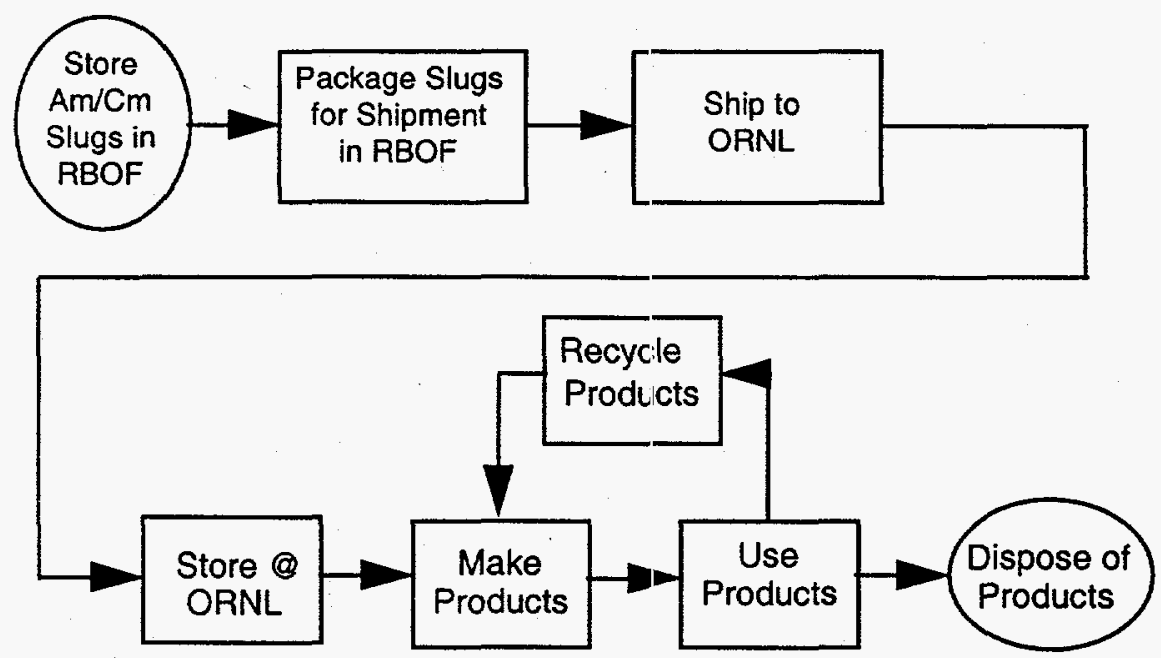

The base case for the Americium and Curium slug disposition begins with slugs/other stored in RBOF and finishes at ORNL.

\section{Premise : Slug/Other Disposition - Base Alternative}

- All operations are performed in the RBOF basin.

- The slugs/other provide primary containment for radionuclides.

- The shipping package is mechanically sealecl with slugs/other per package

- A Helium atmosphere is provided internal to the package.

- Existing RBOF equipment is utilized to load the package into the On-site shipping cask.

- RBOF decontaminates a qualified Off-site shipping cask for transport to ORNL

- The off-site transport cask into which the package is placed is qualified as a secondary containment for shipment.

- ORNL receives the Off-site shipping cask, unloads and stores the package as a unit while returning the off-site shipping cask to SRS.

\section{Primary functions - Slug/Other Disposition - Base Alternative}

9.9.9.1 Load Am/Cm slugs/other in the packiage for shipment

\subsubsection{Ship to ORNL via RBOF}

9.9.9.3 Store material at ORNL.

\section{Schedule}

- $\mathrm{Am} / \mathrm{Cm}$ slugs/other to be removed from FBBF by year 2001.

- Packaging of $\mathrm{Am} / \mathrm{Cm}$ slugs/other to start 5/99 and be completed by $1 / 00$.

- Round trip for off-site canisters to ORNL and back to RBOF $\approx 2$ weeks

- ORNL to receive all shipments including Mark 18 s by 2006

Rates

- TBD packages of TBD Am/Cm slugs/other each produced between $6 / 00$ and $9 / 00$ 
Cost

\section{Appendix 1}

- Design and packaging efforts in RBOF .- \$1M

- Design and installation of storage space at ORNL - \$7M (Not included)

- The design and licensing of a double containment cask for shipment of $\mathrm{Am} / \mathrm{Cm}$ to ORNL. - \$4M (Not included)

- Operational cost of ORNL not included - Ongoing operation.

Enabling Objectives

- Obtain funding for equipment development

- Add storage area to ORNL

\subsubsection{Function: Load Am/Cm slugs/other in the package for shipment - Slug/Other Disposition - Base Alternative}

Sub-functions:

- Load Am/Cm Slugs/other in the package

- Blowout, backfill with Helium and seal

- Leak test package

\section{Requirements}

- Cans shall meet leak rate requirements

Interfaces:

- RBOF equipment including new leak test equipment

- NLI 1/2 or NAC LWT casks

Issues:

- NEPA evaluation

Assumptions:

- The few Slugs/others that may not fit current storage configurations at ORNL will be able to be stored within ORNL cells.

Schedule:

- Start 5/99 complete $1 / 00$

Cost:

- Package/load estimate (including shipping) is $\$ 1 \mathrm{M}$

\subsubsection{Function: Ship to ORNL - Slug/Other Disposition - Base Alternative}

See Tank 17.1 Solution Base Case Function 9.9.1.5

\subsubsection{Function: Store Material at ORNL- Slug/Other Disposition - Base Alternative}

See Tank 17.1 Solution Base Case Function 9.9.1.6 


\section{Appendix J}

\subsection{Appendix J: "National Asset" Recommendation}

The NMI Project Team has requested materials be identified that comply with a proposal for establishing specific materials as "National Assets". The glass produced from Am/Cm in solution at SRS is a prime example of material that could be designated as a national asset.

\subsubsection{Am/Cm Solution National Asset Recommendation, Chuck Alexander, ORNL}

Ref: e-mail Per Chuck Alexander To William N. Jackson dated March 31, 1998

SRS Am/Cm Solution

1) Are there potential scientific or economic benefits from the future use of this material?

Absolutely yes! Some of the potential benefits are as follows:

Feedstock for the U.S. Heavy Element Program

Feedstock for foreign heavy element programs

Waste partitioning and transmutation research and development

Criticality studies

Defense programs

Research, development, and technology of the actinides and transactinides -basic studies of Am and $\mathrm{Cm}$

-target material for the production of the transactinide elements

2) Will U.S. or foreign production facilities for similar quantities exist in the future?

Most likely not. The scale of the reactors and the processing facilities required to produce multikilogram quantities of Am and $\mathrm{Cm}$ are very large and unique. All existing facilities are decades-old or are shut-down. Because of the down-lurn in defense-related nuclear materials production it is doubtful that the U.S. will construct any facilities on this scale solely for the production of only Am and $\mathrm{Cm}$. No foreign facilities of this scale exist that are capable of recovering $\mathrm{Am}$ and $\mathrm{Cm}$. We have heard rumor that the Russians have recovered some $\mathrm{Cm}$ at Chelyabinsk but we do not know the amount or have been able to confirm the rumor. However, their facilities are on the same age as the U.S. facilities are. Commercial reprocessing plants are not built to recover Am and $\mathrm{Cm}$. The Am in commercial spent fuel is also predominantly Am-241. Therefore, recovery in future commercial processing facilities does not address the production and supply of Am-243.

3) What would production cost today?

To build a production reactor and a processing facility of the scale and through-put of those currently existing at SRS would be in excess of 2 billion dollars. This is exclusive of the actual.costs of procuring reactor feed-stock, fabrication of targets, reactor time, and process operating costs. These costs could be expected to be on the order of 50 million dollars a year. The lead time for the construction of these facilities could be expected to be on the order of $10-20$ years.

4) What is the relative cost of safe disposal versus safe storage, including any pretreatment that may be required?

This is currently unknown because safe disposal of the SRS Am/Cm Solution has not been demonstrated on a reasonable scale.

5) If safe storage costs are significantly greater than current costs of disposal, do the potential benefits justify safe storage and for how long?

This is currently unknown because the costs of disposal have not been quantified. 


\section{Appendix $\mathbf{J}$}

6) Does a safe disposal method exist today?

We do not believe one does exist. However, we believe safe disposal is feasible.

7) Does a safe long-term storage facility exist today?

No, one does not exist. Interim storage of the $A m / C m$ could be maintained at either the F-Canyon or RBOF(if proper precautions were taken).

8) Do criteria for safe disposal or storage exist?

Not explicitly. However, we feel that the criteria for safe storage are much more attainable.

9) Is pretreatment required to meet criteria?

Even though no explicit criteria exists, both safe disposal and storage will require some pretreatment or treatment due to the fact that the $\mathrm{Am} / \mathrm{Cm}$ is in an acidic solution.

Chuck Alexander

\subsubsection{Am/Cm Solution Value, Seaborg 1994}

Letter to H. R. O'Leary (DOE Secretary of Energy) from G.T. Seaborg (Lawrence Berkeley Laboratory), expressing value of Am/Cm solution located at SRS, May 11, 1994

\subsubsection{Am/ Cm Solution Value, Seaborg 1992}

Letter to Richard A. Claytor (DOE Assistant Secretary for Defense Programs) from G.T. Seaborg (Lawrence Berkeley Laboratory), expressing value of Am/Cm solution located at SRS, December 16, 1992

\subsubsection{Am/Cm Solution Potential Uses, Seaborg 1992}

Letter to Richard A. Claytor (DOE Assistant Secretary for Defense Programs) from G.T. Seaborg (Lawrence Berkeley Laboratory), expressing potential uses of $\mathrm{Am} / \mathrm{Cm}$ solution located at SRS, December 16, 1992 


\section{Appendix K}

\subsection{Appendix K: Cost Analysis}

Costs were based on the information that is available for a specific alternative. Costs were estimated as incremental increases over current operations. These alternative cost estimates are to be categorized as planning estimates. The DOE Cost Guide, Volume 6 states that planning estimates should have an accuracy range from -50 pericent to +100 percent, which costs within this report are intended to reach

The functions Store $\mathrm{Am} / \mathrm{Cm}$ Solution, Store $M \mathrm{kk} 18 \mathrm{~s}$, and Store $\mathrm{Am} / \mathrm{Cm}$ slugs/other are currently funded and not considered in this analysis. The function Make Glass is common to all Am/Cm solution analyses and the Mk 18 Alternative One. The function "Make Glass" is currently part of an ongoing project to vitrify Am/Cm currently in solution within F-Canyon, with an $\$ 80 \mathrm{M}$ total estimate including R\&D, the project and glass operations. The function Store at ORNL is also a common function and not fully analyzed. ORNL estimates that upgrading Cell E of Bldg 7930 at a cost of $\$ 15 \mathrm{M}$ would be required to accommodate Am/Cm glass storiage. ORNL is currently also pursuing a role in Pu-238 production. If that mission is realized, it wou d allow cost sharing and reduce ORNL storage to about $\$ 7 \mathrm{M}$. The $\$ 7 \mathrm{M}$ cost is used as a basis for this estimate.

Note: Functions are detailed in previous sections of this report. To obtain a better perspective on what a given cost covers the functions should be reviewed.

\subsubsection{Tank 17.1 "Solution" Disposition - Base Alternative}

\section{Function -Weld CwP-1}

Cost estimates for developing MPPF full penetration welding capability, including a weld head, training and qualification, range from about $\$ 300 \mathrm{~K}$ to $\$ 700 \mathrm{~K}$. (Ref 3 ) Installing the welder in MPPF as a project during the current $A m / C m$ project is estimated to be $\$ 1 \mathrm{M}$. Since this requires qualification to meet shipping requirements, the high end is chosen for a total cost of $\$ 1.7 \mathrm{M}$.

\section{Function - Transport to RBOF}

On-site transportation to RBOF from F-Canyon would require $\$ 150 \mathrm{~K}$ to $\$ 300 \mathrm{~K}$.

The cost to transport a loaded CD cask from F-Canyon to RBOF is estimated at $\$ 1.5 \mathrm{~K}$ ( 3 workers @ $\$ 65 / \mathrm{hr}, 1-8 \mathrm{hr}$ day). The cost to unload at REOF is estimated at $\$ 2 \mathrm{~K}$ ( $\$ 10 \mathrm{~K} /$ week operation costs, 1 day to turn around the CD cask). The cost to load at F-Canyon is estimated at $\$ 4 \mathrm{~K}$. The total cost per CD shipment is therefore $\$ 7.5 \mathrm{~K}$. The total number of shipments is estimated at 20 to 40 (depending on the total number of canisters and number of canisters per CD cask), therefore the estimated transport cost is $\$ 150 \mathrm{~K}$ to $\$ 300 \mathrm{~K}$.

\section{Function - Store in RBOF}

On-site storage at RBOF would increase the facilities incremental cost during placement into storage, which would be covered by the above transport costs. But, if RBOF was to remain open only for these materials a cost of $\sim \$ 10 \mathrm{~K}$ per week would be incurred to cover RBOF operations/maintenance costs. Based on current planning, the storage would not cause any delay in RBOF shutdown. 


\section{Appendix K}

\section{Function - Ship to ORNL via RBOF}

For 150 canisters shipping at 8 canisters per cask (therefore 19 shipments) at $\$ 60 \mathrm{~K} /$ shipment (Ref 4$)$ the cost would be $\$ 1.2 \mathrm{M}$. For 200 canisters shipping at 6 canisters per cask (therefore 34 shipments) at $\$ 60 \mathrm{~K} /$ shipment (Ref 4 ) the cost would be $\$ 2 \mathrm{M}$. It would cost an additional $\$ 1.5 \mathrm{M}$ to provide cask certification. If desired, procurement of a double containment cask would cost $\$ 3.0 \mathrm{M}$. Shipment costs assume cask rental at $\$ 1.2-2.0 \mathrm{M}$.

\subsubsection{Tank 17.1 "Solution" Disposition - Alternative One}

\section{Function - Transport to RBOF}

On-site transportation to RBOF from F-Canyon would require $\$ 150 \mathrm{~K}$ to $\$ 300 \mathrm{~K}$.

\section{Function - Weld Contamination Barrier (CWP-3)}

Total estimated costs: $\$ 3 M$

This operation is somewhere in cost between the cost of welding in MPPF and the cost of setting up underwater equipment for Mk 18 cutting, estimate: $\$ 3 M$.

\section{Function - Mechanical Seal msQSC}

Total estimated cost: $\$ 390 \mathrm{~K}-\$ 430 \mathrm{~K}$

The cost for the container and sealing operation is considered to be within the Weld Contamination Barrier cost. The msQSC is a mechanical container which will have requirements similar to DWPF or SNF canisters. Estimate a cost of $\$ 5 \mathrm{~K}$ per msQSC or for $19-25 \mathrm{msQSCs} \$ 90 \mathrm{~K}-\$ 130 \mathrm{~K}$. Assume the msQSC design cost and associated tests would be $\$ 300 \mathrm{~K}$.

\section{Function - Ship to ORNL via RBOF}

Total estimated costs: $\$ 2.7 \mathrm{M}-\$ 3.5 \mathrm{M}$

For 150 canisters shipping at 8 canisters per cask (therefore 19 shipments) at $\$ 60 \mathrm{~K} /$ shipment (Ref 4$)$ the cost would be $\$ 1.2 \mathrm{M}$. For 200 canisters shipping at 6 canisters per cask (therefore 34 shipments) at $\$ 60 \mathrm{~K} /$ shipment (Ref 4 ) the cost would be $\$ 2 \mathrm{M}$. It would cost an additional $\$ 1.5 \mathrm{M}$ to provide cask certification. If desired, procurement of a double containment cask would cost $\$ 3.0 \mathrm{M}$. Shipment costs assume cask rental at \$1.2-2.0M.

\subsubsection{Tank 17.1 "Solution" Disposition - Alternative Two}

\section{Function -Weld CwP-1}

Total estimated costs: $\$ 1.7 \mathrm{M}$

Cost estimates for developing MPPF full penetration welding capability including a weld head, training and qualification range from about $\$ 300 \mathrm{~K}$ to $\$ 700 \mathrm{~K}$. (Ref 3) Installing the welder in MPPF as a project during the current $A m / C m$ project is estimated to be $\$ 1 \mathrm{M}$. Since this requires qualification to meet shipping requirements, the high end was chosen forr a total cost of $\$ 1.7 \mathrm{M}$. 
WESTINGHOUSE SAVANNAH RIVER COMPANY

Americium/Curium Disposition Life Cycle Planning Stucly(U
Document: NMP.PLS-980044

Revision 0

April 30, 1998

Page 108 of 159

\section{Appendix K}

\section{Function - Store in F-Canyon}

Storage would not add any appreciable costs; unless F-Canyon had to remain open just due to the $\mathrm{Am} / \mathrm{Cm}$ storage. Current planning is preliminary enough (including potential 94-1 mission assistance to Rocky Flats processing residues, fluorides elc.) that it is not expected that the canyon will have completed decommissioning activities prior to completing Am/Cm glass storage. Significant staff and facility support will also be required during the first three years of decommissioning activities.

\section{Function - Ship to ORNL via F-Canyon}

\section{Total estimated cost: $\$ 2.7 \mathrm{M}-3.5 \mathrm{M}$}

For 150 canisters shipping at 8 canisters per cask (therefore 19 shipments) at $\$ 60 \mathrm{~K} /$ shipment (Ref 4 ) the cost would be $\$ 1.2 \mathrm{M}$. For 200 canisters shipping at 6 canisters per cask (therefore 34 shipments) at $\$ 60 \mathrm{~K} / \mathrm{sh}$ ipment (Ref 4 ) the cost would be $\$ 2 \mathrm{M}$. It would cost an additional $\$ 1.5 \mathrm{M}$ to provide cask certification. If desired, procurement of a dcuble containment cask would cost $\$ 3.0 \mathrm{M}$. Shipment costs assume cask rental at \$1.2-2.0M.If an additional decontamination shed is needed to prepare the Offsite cask for shipping, it is estimated to cost about $\$ 300 \mathrm{~K}$ for a Butler type building (this is not included in the estimate). It should be noted that this decontamination building could also be used to aid in D\&D of the Canyon thus sharing that cost.

\subsubsection{Tank 17.1 "Solution" Disposition - Alternative Three}

\section{Function -Weld Contamination Barrier (CwP.2)}

Total estimated cost: $\$ 1.3 \mathrm{M}$

Cost estimates for developing MPPF full penetration welding capability including a weld head, training and qualification range from about $\$ 300 \mathrm{~K}$ to $\$ 700 \mathrm{~K}$. (Ref 3 ) Installing the welder in MPPF as a project during the current $\mathrm{Am} / \mathrm{Cm}$ project for a seal weld is estimated to be $\$ 1.0 \mathrm{M}$. It is assumed that welding a seal weld instead of a full penetration weld would require less qualification, thus slightly lower cost, so the low range is used as the estimate: $\$ 1.3 \mathrm{M}$ total.

\section{Function - Store in F-Canyon}

Storage would not add any appreciable costs, unless F-Canyon had to remain open just due to the Am/Cm storage. Current planning is preliminary enough (including potential 94-1 mission assistance to Rocky Flats processing residues, fluorides etc.) that it is not expected that the canyon will have completed decommissioning activities prior to completing Am/Cm glass storage. Significant staff and facility support will also be required during the first three years of decommissioning activities.

\section{Function - Ship to ORNL via F-Canyon}

Total estimated cost: $\$ 2.7 \mathrm{M}-\$ 3.5 \mathrm{M}$

For 150 canisters shipping at 8 canisters per cask (therefore 19 shipments) at $\$ 60 \mathrm{~K} /$ shipment (Ref 4 ) the cost would be $\$ 1.2 \mathrm{M}$. For 200 canisters shipping at 6 canisters per cask (therefore 34 shipments) at $\$ 60 \mathrm{~K} /$ shipment (Ref 4 ) the cost would be $\$ 2 \mathrm{M}$. It would cost an additional $\$ 1.5 \mathrm{M}$ to provide cask certification. If desired, procurement of a double containment cask would cost $\$ 3.0 \mathrm{M}$. Shipment costs assume cask rental at $\$ 1.2-2.0 \mathrm{M}$. It should be noted that this assumes that the $A \mathrm{~m} / \mathrm{Cm}$ glass is successfully argued to provide primary contetinment of residual plutonium. If an additional decontamination shed is needed to prepare the Off-site cask for shipping, it is estimated to cost about 


\section{Appendix K}

$\$ 300 \mathrm{~K}$ for a Butler type building (Not included in the estimate0). It should be noted that this decontamination building could also be used to aid in D\&D of the Canyon thus sharing that cost.

\subsubsection{Tank 17.1 "Solution" Disposition - Alternative Four}

\section{Function -Weld Contamination Barrier (CwP-2)}

Total estimated cost: $\$ 1.3 \mathrm{M}$

Cost estimates for developing MPPF full penetration welding capability including a weld head, training and qualification range from about $\$ 300 \mathrm{~K}$ to $\$ 700 \mathrm{~K}$. (Ref 3 ) Installing the welder in MPPF as a project for a seal weld during the current $A m / C m$ project is estimated to be $\$ 1.0 \mathrm{M}$. It is assumed that welding a seal weld instead of a full penetration weld would require less qualification, thus slightly lower cost, so the low range is used as the estimate: $\$ 1.3 \mathrm{M}$ total.

\section{Function - Store in F-Canyon}

Storage would not add any appreciable costs, unless F-Canyon had to remain open just due to the $\mathrm{Am} / \mathrm{Cm}$ storage. Current planning is preliminary enough (including potential 94-1 mission assistance to Rocky Flats processing residues, fluorides etc.) that it is not expected that the canyon will have completed decommissioning activities prior to completing Am/Cm glass storage. Significant staff and facility support will also be required during the first three years of decommissioning activities.

\section{Function - Transport to L-Basin}

On-site transportation to L-Basin from F-Canyon would require $\$ 150 \mathrm{~K}$ to $\$ 300 \mathrm{~K}$.

\section{Function -Load Glass Canister into msQSC}

Total estimated cost: \$390K-\$430K

Canisters would be loaded into an msQSC either in L-Basin itself, or in the new Spent Fuel management facility (currently in planning) in the L-Reactor process area. Loading the msQSC is within normal operating costs. The msQSC is a mechanical container which will have requirements similar to DWPF or SNF canisters. Estimate a cost of $\$ 5 \mathrm{~K}$ per msQSC or for 19-25 msQSCs $\$ 90$ $130 \mathrm{~K}$. Assume the msQSC design cost and associated tests would be $\$ 300 \mathrm{~K}$.

\section{Function - Store msQSC in Dry Storage Cask}

$-$

The 19-25 msQSCs would be stored in horizontal dry storage casks. Assuming a cost of $\$ 400 \mathrm{~K} /$ cask and $6 \mathrm{msQSCs}$ per cask this represents $\$ 1.3 \mathrm{M}$ to $\$ 1.7 \mathrm{M}$.

\section{Function - Ship to ORNL}

Total estimated cost: $\$ 2.7 \mathrm{M}-\$ 3.5 \mathrm{M}$

For 150 canisters shipping at 8 canisters per cask (therefore 19 shipments) at $\$ 60 \mathrm{~K} /$ shipment (Ref 4 ) the cost would be $\$ 1.2 \mathrm{M}$. For 200 canisters shipping at 6 canisters per cask (therefore 34 shipments) at $\$ 60 \mathrm{~K} /$ shipment (Ref 4 ) the cost would be $\$ 2 \mathrm{M}$. It would cost an additional $\$ 1.5 \mathrm{M}$ to provide cask certification. If desired, procurement of a double containment cask would cost $\$ 3.0 \mathrm{M}$. Shipment costs assume cask rental at $\$ 1.2-2.0 \mathrm{M}$. 
WESTINGHOUSE SAVANNAH RIVER COMPANY

Americium/Cürium Disposition Life Cycle Planning Sturdy(U
Document: NMP-PLS-980044

Revision 0

April 30, 1998

Page 110 of 159

\section{Appendix K}

\subsubsection{Tank 17.1 "Solution" Disposition - Alternative Five}

Function -Weld Contamination Barrier (CwP-2)

Total estimated cost: $\$ 1.3 \mathrm{M}$

Cost estimates for developing MPPF full peretration welding capability including a weld head, training and qualification range from about $\$ 300 \mathrm{~K}$ to $\$ 700 \mathrm{~K}$. (Ref 3 ) Installing the welder in MPPF as a project for a seal weld during the current $\mathrm{Am} / \mathrm{Cm}$ project is estimated to be $\$ 1.0 \mathrm{M}$. It is assumed that welding a seal weld instead of a full penetration weld would require less qualification, thus slightly lower cost, so the low range is used as the estimate: $\$ 1.3 \mathrm{I}$ total.

\section{Function - Store in F-Canyon}

Storage would not add any appreciable costs, unless F-Canyon had to remain open just due to the $\mathrm{Am} / \mathrm{Cm}$ storage. Current planning is preliminary enough (including potential 94-1 mission assistance to Rocky Flats processing residues, fluorides etc.) that it is not expected that the canyon will have completed decommissioning activities prior to completing Am/Cm glass storage. Significant staff and facility support will also be required during the first three years of decommissioning activities.

\section{Function - Transport to L-Basin}

On-site transportation to L-Basin from F-Canyon would require $\$ 150 \mathrm{~K}$ to $\$ 300 \mathrm{~K}$.

\section{Function - Load CwP-2 in SNF Canister}

Assuming that three CwP-2s can be loaded into a 10' long SNF canister, 25-34 canisters would be needed. At an estimated cost of $\$ 20 \mathrm{~K}$ per canister this represents $\$ 500 \mathrm{~K}$ to $\$ 700 \mathrm{~K}$. Loading operational costs are expected to be within normal operating costs for the new Spent Fuel facility (currently in planning) in the L-Reactor process area.

\section{Function - Store containers at L Reactor (Dyy Storage)}

Spent Fuel canisters are stored 6 to a concrete storage cask at an estimated cost of $\$ 400 \mathrm{~K} / \mathrm{cask}$ Assuming that the glass canister filled SNF zanisters are compatible with normal SNF canisters, this represents $\$ 1.7 \mathrm{M}-\$ 2.3 \mathrm{M}$.

\section{Function - Ship containers to Repository (MGDS)}

Total estimated cost: $\$ 2.8 \mathrm{M}-\$ 3.8 \mathrm{M}$

SNF canisters are planned to be shipped to the Repository (MGDS) at seven canisters per cask. Estimated cost for a shipment of a dedicated five car train is $\$ 504 \mathrm{~K}$. For $25-34$ canisters this represents $\$ 360 \mathrm{~K}-\$ 490 \mathrm{~K}$. Canisters are ernplaced in the center of a co-disposal overpack at a total cost of $\$ 580 \mathrm{~K}$ overpack. Emplacing 25-34 canisters represents a cost of $\$ 2.4 \mathrm{M}-\$ 3.3 \mathrm{M}$ 
Appendix K

\subsection{7. "Mark 18s" Disposition - Base Case}

\section{Function - Cut Mk 18 for Shipment to ORNL}

Total estimated cost: $\$ 15 \mathrm{M}$

Equipment development and installation to cut and package Mk 18's was considered similar in complexity and cost to putting in a glove box line. Because of the unknown brittleness and condition of the Mark 18s it was assumed that an underwater dry-box operation would be needed. Based on previous experience it is estimated that putting in a robotized underwater dry box cutting and packaging system would cost about $\$ 15 \mathrm{M}$. A capability without an underwater drybox was estimated in 1993 to be $\$ 3.6 \mathrm{M}$ (Ref.1). Escalated to 1998 dollars, this is approximately $\$ 5 \mathrm{M}$. The increase in cost is attributable to the increase in complexity and scope.

\section{Function - Package for Shipment}

Costs for packaging are included in the previous function estimate.

\section{Function - Ship to ORNL from RBOF}

Total estimated cost: $\$ 2.0 \mathrm{M}$

The cost for 33 shipments (two Mk 18 s per shipment) at $\$ 60 \mathrm{~K} /$ shipment (Ref 4 ) is $\$ 2 \mathrm{M}$. It would cost an additional $\$ 1.5 \mathrm{M}$ to provide cask certification. If desired, procurement of a double containment cask would cost $\$ 3.0 \mathrm{M}$. Since both certification would be driven by $\mathrm{Am} / \mathrm{Cm}$ "solution" glass canisters, costs of certification are not included in this estimate. It is assumed the cask would be rented.

\section{Function - Store at ORNL}

Total estimated cost: $\$ 3 \mathrm{M}$

The cost of preparing storage for longer canisters at ORNL is estimated at \$2M. Handling equipment would require modifications and testing estimated at $\$ 1 \mathrm{M}$.

\subsection{8. "Mark 18s" Disposition - Alternative One}

(Note: this scenario assumes Am/Cm solution "alternative three" for a glass shipment basis)

\section{Function Ship to F-Canyon}

Total estimated costs: $\$ 200 \mathrm{~K}$

\section{Function Dissolve Mk 18s}

Total estimated cost: $\$ 5.5 \mathrm{M}$

Based on previous projects to put dissolvers in F-Canyon section 17 the cost was estimated to be $\$ 3$ $6 \mathrm{M}($ Ref 2$)$. The midpoint of the estimate is $\$ 4.5 \mathrm{M}$. The cost of operations to dissolve the Mk18's is estimated at $\$ 1 \mathrm{M}$.

\section{Function - Weld Secondary Contamination Barrier \& Make Glass}

Total estimated cost: $\$ 1.5 \mathrm{M}$ 


\section{Appendix K}

At this point the costs would be for the additional operations to make the glass, fill the canisters, load the secondary canisters, and seal weld the seisondary canisters. It is estimated this would be complete in 2 to 4 months and would cost $\$ 1 M$ to $2 M$.

\section{Function - Store in F-Canyon}

Storage would not add any appreciable costs, unless F-Canyon had to remain open just due to the Am/Cm storage. Current planning is preliminary enough (including potential 94-1 mission assistance to Rocky Flats processing residues, fluorides etc.) that it is not expected that the canyon will have completed decommissioning activities prior to completing Am/Cm glass storage. Significant staff and facility support will also be required during the first three years of decommissioning activities.

\section{Function - Ship to ORNL via F-Canyon}

Total estimated costs; $\$ 420 \mathrm{~K}$

For approximately 50 canisters (based on $\mathrm{Cm}$ content) shipping at 8 canisters per cask at $\$ 60 \mathrm{~K} /$ shipment (Ref 4 ) the cost would be $\$ 420 \mathrm{~K}$. Certification costs would be included in the Am/Cm glass certification. If an additional decontamination shed is needed it would have been added in the earlier shipments for "solution" made into glass and shipped to ORNL.

\subsection{9. "Slugs/Other" Disposition - Base Casse}

Total estimated cost: $\$ 1 \mathrm{M}$ As these slugs/other represent a very small anount of material, it is expected that any costs will be covered (other than shipments) by Am/Cm solution and Mk 18 programs. Shipment is estimated at $1 \mathrm{M}$.

Appendix 9.11, References:

1. Letter, R. Maher to C.C. Mason, "Evaluation of an Oak Ridge National Laboratory Proposal for the Canning and Shipment of Mark (Mk) -18 Target Rods to ORNL", NMP-VP-93212, dated November 18, 1993

2. W. H. Martin, personal communication March, 1998.

3. S. Nester, personal communication, March 1998.

4. R. Rainisch, personal communication, March, 1998 


\section{Appendix L}

\subsection{Appendix L: Disposition Path Evaluations}

\subsubsection{Disposition Path Maturity Evaluations}

Disposition Path Maturity's for the Am/ Cm Tank 17.1 solution base case, its three alternatives and for the Mk 18 base case and its alternative were initially developed in a concentrated one-day effort by cognizant domain experts with the assistance of a Nuclear Matterials Integration Systems Engineer and the Core Team. The analysis was performed according to the NMI handbook. However, this was the first time the methodology was used for multi-step process analysis. After documenting all of the DPM evaluations the Core Team reviewed the results for consistency, made recommended changes, contacted domain experts as needed for verification, and documented the logic for specific evaluations in Appendix M. This same process was used for additional alternatives identified. Summaries of these analyses are given below in sections 9.12.1.1 through 9.12.1.6.

The following discussion describes the NMI disposition path maturity analysis performed to support this study. It is extracted from the latest draft NMI Handbook. Disposition Path Maturity (DPM) is a measure of the time it will take needed to bring a process or technology to full production line operation. DPM is a component of Disposition Path Risk (Rdp) which is defined as:

$$
\mathrm{Rdp}=\mathrm{Pi}^{*} \mathrm{Cs} \text {; }
$$

where $\mathrm{Pi}=$ Probability of Immaturity = DPM/10

and $\mathrm{Cs}=$ Schedule Consequence of Failure

Disposition Path Maturity (DPM) score for each function on the path is:

$$
D P M=S U M(\text { category wt }(C W) \text { * category maturity level)/SUM(CW) }
$$

Schedule consequence (Cs) is:

$$
\text { Cs }=1-((\text { Need date }- \text { evaluation date in yrs })) / 3.4^{\star} y r s
$$

*Note: 3.4 years is the estimated time to take a project to be installed within a facility (like a glovebox line melter) from concept (DPM $=10)$ to operation (DPM $=0$ ).

Risk and Maturity evaluation requires collection of the following data, available from program plans, flowsheets, material balance sheets, and other site process descriptions:

- Function description

- Material category/type

- Material form (input/output)

- Material location

- Proposed technology

- Technology development site

- End-use site

- Evaluator(s)

- Evaluation date

- Operational need date. 


\section{Appendix L}

The following DPM factors must be evaluated for each function in disposition path. Scoring is accomplished by assessing scoring criteria for each of the following factors:

- Requirements maturity (RM)

- Process maturity

- Processing and storage (PM) or

- Transportation (TPM)

- Hardware/equipment maturity

- Processing and storage (EQ) or

- Transportation (TEQ)

- Facility readiness maturity (FAC)

- Operational safety maturity (SAFT)

- Personnel resource status (PER)

- Schedule maturity (SCH)

- NEPA readiness (NEPA)

Weighting for each factor are [category weights (CW)]:

$\begin{array}{cll}\text { Maturity category } & \text { CW } & \text { score } \\ \text { RM } & \text { medium (0.3) } & \\ \text { PM } & \text { high } & (0.9) \\ \text { EQ } & \text { high } & (0.9) \\ \text { FA } & \text { high } & (0.9) \\ \text { SAFT } & \text { medium } & (0.3) \\ \text { PER } & \text { low } & (0.1) \\ \text { SCH } & \text { medium } & (0.3) \\ \text { NEPA } & \text { high } & (0.9)\end{array}$




\section{Appendix $L$}

\section{Requirements Maturity (RM) Scale}

\begin{tabular}{|c|c|}
\hline Levet & Maturity Assessment Criteria \\
\hline 10 & Mission objectives not quantifled or baselined ( \\
\hline 8 & $\begin{array}{l}\text { System concept form ulated, but flow sheet description (process inputs, outp uts, volumes, } \\
\text { and rates is incomplete and/or driving component performance parameters (e.g., storage } \\
\text { duration. Lol) are not ldentified L volatilly in systom concept }\end{array}$ \\
\hline 6 & $\begin{array}{l}\text { Flowsheet description complete and appllcablity of this component understood. } \\
\text { Performance parameters are Identified, but most parameter values are not quantifled } \\
\text { (volatility in key requirements }\end{array}$ \\
\hline 4 & $\begin{array}{l}\text { Flowsheet description and Impact on th is component understood. Most driving performance } \\
\text { parameter values for component have "first pass" values or the supporting analysis is } \\
\text { incomplete (volatility in minor requirements ) }\end{array}$ \\
\hline 3 & $\begin{array}{l}\text { All parameter values which drive the component selection have been resolved and } \\
\text { supporting analysis is complete( littlo to no change in requirements expected ) }\end{array}$ \\
\hline 2 & $\begin{array}{l}\text { Detalled design parameters and operational requirements are established. As necessary, } \\
\text { requirement and parameter values have been valldated by models of appropriate fidelity. } \\
\text { Specification is under formal configuration control ( changes in requirements cause contract } \\
\text { changes) }\end{array}$ \\
\hline 1 & $\begin{array}{l}\text { Verification test procedures written to dem onstrate that component satisfles requirements } \\
\text { (component test plan complete) }\end{array}$ \\
\hline 0 & Design procedures complete and results are acceptable ( \\
\hline
\end{tabular}

Processing \& Storage Process Maturity (PM) Scale

\begin{tabular}{|c|c|c|}
\hline & Level & Maturity $A=s e s=m e n t c$ rlterle \\
\hline & 10 & No currently id entifled olutions that meets requirements \\
\hline & ? & Design conceptendfor technology applicetion formulated. \\
\hline I & 8 & Cold leasibility demonstrated \\
\hline I & 6 & Hot feastbility demonetrated \\
\hline | & 5 & Endto-end deslgn (flowsheet) complete \\
\hline I & 4 & Cold prototypedemonstrated uendersesite \\
\hline I & 2 & Hotprototypedemonotrated atend-usesite \\
\hline I & 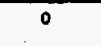 & Procest integrated Into operallons \\
\hline
\end{tabular}




\section{Appendix $\mathrm{L}$}

Transportation Process Maturity (TPM) Scale

\begin{tabular}{|l|l|}
\hline Level & \multicolumn{1}{|c|}{ Maturity Assessment Criteria } \\
\hline 10 & No currently Identified solutions that meets requirements \\
\hline 9 & Design conceptand/or technology applications formulated. \\
\hline 7 & Analogous system In operation that transports similar material. \\
\hline 5 & End-to-end system design complete \\
\hline 4 & Prototype system demonstrated using cold I surrogate material \\
\hline 2 & Prototype system demonstrated using hot material(1st hot shlpment complete) \\
\hline 0 & Process integrated into operations (several hot shipments completed). \\
\hline
\end{tabular}

Transportation Hardware Equipment Maturity (TEQ) Scale

\begin{tabular}{|c|l|}
\hline Level & \multicolumn{1}{|c|}{ Maturity Assessment Criteria } \\
\hline 10 & Equipment* requirements not yut defined \\
\hline 9 & New design. Conceptual desigri completed. \\
\hline 7 & Equipment certified. \\
\hline 5 & Certified equipment avallable. Unsufficient quantiles avallable to meet need. \\
\hline 4 & Plan complete to manufacture adequate quantiles of equipment. \\
\hline 2 & Sutficlent equipment t begin opisations. \\
\hline 0 & Equipment in use and adequate quantities avallable to complete mission. \\
\hline
\end{tabular}

* This includes all equipment for the system. Use maximum score across all equipment in system. 


\section{Appendix L}

\section{Processing \& Storage Hardware Equipment Maturity (EQ) Scale}

\begin{tabular}{|c|c|c|}
\hline & Level & Maturity Assessment Criteria \\
\hline & 10 & Equipment ${ }^{*}$ requirements not yet defined \\
\hline 1 & 9 & New design. Conceptual design completed. \\
\hline I & 8 & Experimental system. Cold demonstrated. \\
\hline $\mathbf{I}$ & $\overline{7}$ & Experimental system. Hot demonstrated. \\
\hline I & 6 & Commercially equipment available. Requires modification. \\
\hline I & 4 & Integrated end-to-end equipment designs completed. \\
\hline 1 & $\overline{3}$ & Cold prototype demonstrated. \\
\hline I & 1 & Hot prototype demonstrated. \\
\hline I & $\overline{0}$ & Equipment in use processing the given material. \\
\hline
\end{tabular}

* This includes all equipment for the system. Use maximum score across all equipment in system. 


\section{Appiendix $L$}

Facllity Equipment Readiness (FAC) Scale

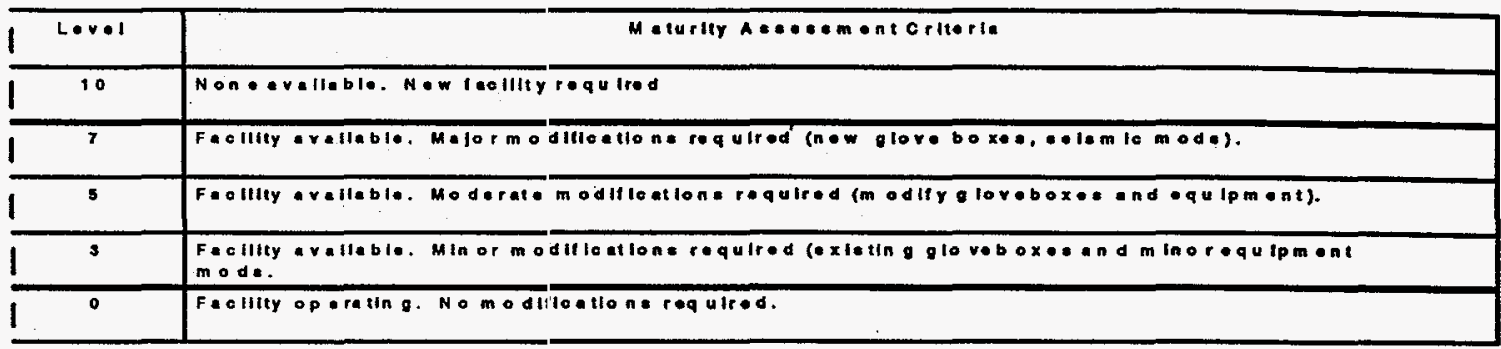

Operational safety Readiness (SAFT) S cale

\begin{tabular}{|c|c|}
\hline$L \bullet V \cdot I$ & Maturity $A=s e s m$ on t criteria \\
\hline 10 & OR R I * quired \\
\hline B & R A required. \\
\hline 6 & Contractor ORR completo. \\
\hline 4 & Contractor RA complete. \\
\hline 2 & DOE ORR complote (aw alting secretery of Energy elgneture). \\
\hline 1 & DOERAcomploto (nwaiting site Mangoerelgnature). \\
\hline 0 & Facllity A TP is ued or wlihin wuthorizatlon bas is. \\
\hline
\end{tabular}




\section{Appendix $L$}

\section{Personnel Resource Status (PER) Scale}

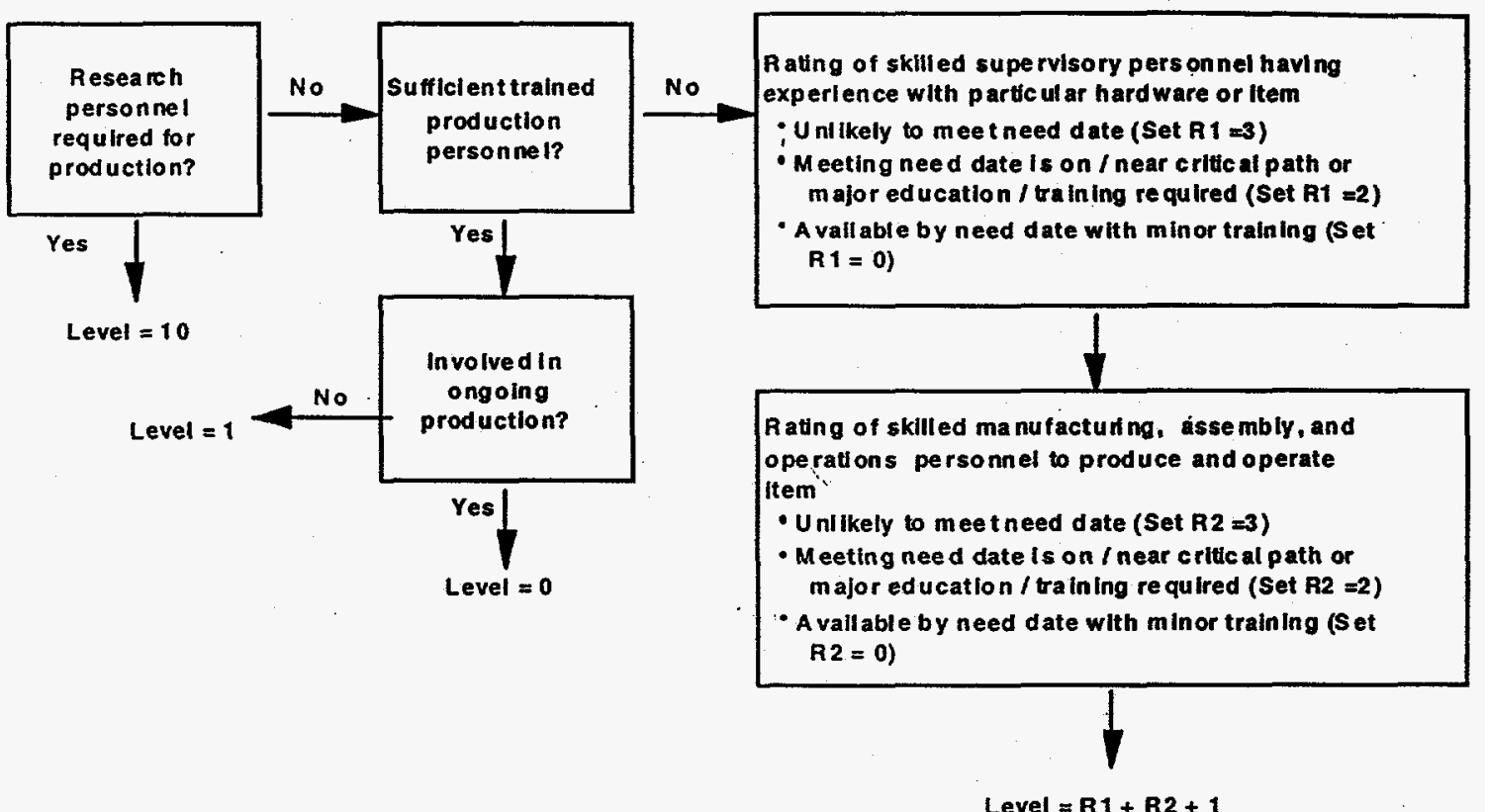

Level $=\mathbf{R} 1+\mathbf{R} 2+1$ 


\section{Appendix L}

\section{Schedule Maturity (SCH) Scale}

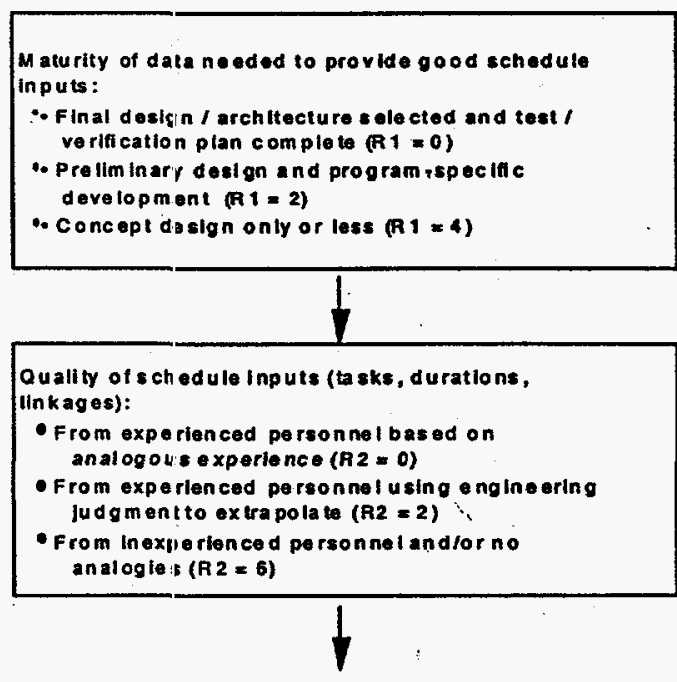

Leve $1=\mathbf{R 1}+\mathbf{R 2}$

NEPA Readiness Scale

\begin{tabular}{|c|c|}
\hline Level & \\
\hline 10 & NEPA determination must be Inade (i.e. EANS EIS; site or project specific) \\
\hline 9 & New site or project specific EIS required. \\
\hline 8 & Notice of Intent issued for EIS \\
\hline 6 & Draft of EIS issued for public comment \\
\hline 4 & Final EIS issued with Record of Decision (ROD) \\
\hline 3 & Supplement to existing EIS needed \\
\hline 2 & Environmental Assessment (EA) required (assumes finding of No Significant Impact) \\
\hline 1 & Categorical Exclusion (CX) required \\
\hline 0 & $\begin{array}{l}\text { Favorable environmental diagnosis issued (e.g. Environmental checklist); no additional } \\
\text { documentation required. }\end{array}$ \\
\hline
\end{tabular}




\section{Appendix L}

\section{End-State skystem Interface Requirements Maturity Scale}

\begin{tabular}{|c|c|c|}
\hline Risk & Score & Maturity Assessment Criteria \\
\hline & 10 & Mission objectives not quantified or baselined \\
\hline High & 8 & $\begin{array}{l}\text { System concept formulated but total system description (processes and interfaces is } \\
\text { incomplete and/or impact of drivign performance parameters (e.g., duration of storage } \\
\text { percent impurities, percent fissile material, level of containment) are not identified } \\
\text { (volatility in system concept) }\end{array}$ \\
\hline \multirow[b]{2}{*}{ Medium } & 6 & $\begin{array}{l}\text { System description complete and applicability of this requirement understood. } \\
\text { Performance parameters are identified, but most parameter values are not quantified } \\
\text { (volatility in key requirements) }\end{array}$ \\
\hline & 4 & $\begin{array}{l}\text { System description complete and impact of this requirement on the design baseline } \\
\text { understood. Most driving performance parameters have "first pass" values or } \\
\text { supporting analysis is incomplete. (volatility in minor requirements). }\end{array}$ \\
\hline \multirow{5}{*}{ Low } & 3 & $\begin{array}{l}\text { All parameter values which drive design baseline selection have been resolved and } \\
\text { supporting analysis is complete (little or no change in requirements expected) }\end{array}$ \\
\hline & 2 & $\begin{array}{l}\text { Detailed design parameters and operational reuirements are established. As necessary } \\
\text { requirement and paramenter values have been validated by models of appropriate }\end{array}$ \\
\hline & & $\begin{array}{l}\text { fidelity. Design specifications are under formal configurartion control ( changes in } \\
\text { requirements cause contract changes) }\end{array}$ \\
\hline & 1 & $\begin{array}{l}\text { Verification test procedures written to demonstrate that design baseline satisfies } \\
\text { requirements (system test plans complete) }\end{array}$ \\
\hline & 0 & $\begin{array}{l}\text { Design test procedure competed and results are acceptable (requirements are verified, } \\
\text { system ready for use.) }\end{array}$ \\
\hline
\end{tabular}

\subsubsection{Tank 17.1 "Solution" Disposition - Base Case"}

\begin{tabular}{|c|c|c|c|c|c|c|c|c|c|c|c|}
\hline Process / Function & \multicolumn{11}{|c|}{ Scoring Factors } \\
\hline Base Case & $\mathbf{R M}$ & PIM & $\mathbf{E Q}$ & $\mathbf{F A}$ & SAFT & PER & SCH & NEPA & EST & FMT & $\mathbf{F M 2}$ \\
\hline weights & 0.3 & 0.9 & 0.9 & 0.9 & 0.3 & 0.1 & 0.3 & 0.9 & 0.9 & 5.5 & 3.7 \\
\hline $\begin{array}{l}\text { Weld Primary } \\
\text { Shipping Container } \\
\text { (PSC) }\end{array}$ & 3 & 4 & 3 & 5 & 0 & 1 & 2 & 0 & 3 & 2.75 & 3.35 \\
\hline Transport to RBOF & 1 & 2 & 2 & 0 & 0 & 0 & 1 & 0 & 1 & 0.93 & 1.14 \\
\hline Store in RBOF & 6 & 2 & 1 & 0 & 2 & 0 & 2 & 0 & 4 & 1.69 & 1.54 \\
\hline Ship to ORNL & $\overline{6}$ & 6 & 10 & o & 8 & 0 & $\overline{4}$ & 6 & 6 & 5.56 & 5.35 \\
\hline Store at ORNL & 10 & 6 & 1 & 7 & 10 & 0 & 4 & 2 & 10 & 5.56 & 5.35 \\
\hline & & & & & & & & & & & \\
\hline $\begin{array}{l}\text { max of } \\
\text { above: }\end{array}$ & 10 & 6 & 10 & 7 & 10 & 1 & 4 & 6 & 10 & & \\
\hline
\end{tabular}

Typical maturity period (years) Need Date

Evaluation Date Years till needed

Schedule Consequence
3.4 5/1/99. Process will be mature in 189 y years $3 / 19 / 98$ 1.12

0.671 


\section{Appendix $L$}

9.12.1.2. Tank 17.1 "Solution" Disposition - Alternative One

\begin{tabular}{|c|c|c|c|c|c|c|c|c|c|c|c|}
\hline Process / Function & \multicolumn{11}{|c|}{ Scoring Factors } \\
\hline Alternative 1 & RIM & PIM & EQ & FA & SAFT & PER & SCH & NEPA & EST & FMT & $F \mid M 2$ \\
\hline weights & 0.3 & 0.9 & 0.9 & 0.9 & 0.3 & 0.1 & 0.3 & 0.9 & 0.9 & 5.5 & 3.7 \\
\hline & & & & & & & & & & & \\
\hline Transport to RBOF & 1 & 2 & 2 & 0 & 0 & 0 & 0 & 0 & 1 & 0.87 & 1.05 \\
\hline $\begin{array}{l}\text { Weld Contamination } \\
\text { Can }\end{array}$ & 8 & 9 & 10 & 7 & 10 & 3 & 6 & 0 & 8 & 6.93 & 8.35 \\
\hline Mechanical Seal & 3 & 2 & 0 & 3 & 0 & 0 & 0 & 0 & 2 & 1.31 & 1.46 \\
\hline Store in RBOF & $\overline{6}$ & 2 & 1 & 0 & 2 & 0 & 2 & 0 & 4 & 1.69 & 1.54 \\
\hline Ship to ORNL & 6 & 6 & 10 & 0 & 8 & 0 & 4 & 6 & 6 & 5.56 & 5.35 \\
\hline Store at ORNL & 10 & 6 & 1 & 7 & 10 & 0 & 4 & 2 & 10 & 5.56 & 5.35 \\
\hline & & & & & & & & & & & \\
\hline above: & 10 & 9 & 10 & 7 & 10 & 3 & 6 & 6 & 10 & & \\
\hline
\end{tabular}

\author{
Typical maturity period (years) \\ Need Date \\ Evaluation Date \\ Years till needed
}

Schedule Consequence

\section{4}

$5 / 1 / 99$ $3 / 3 / 98$

1.16
Process will be mature in 420 years

Schedule Risk

0.5

\subsubsection{Tank 17.1 "Solution" Disposition - Alternative Two}

\begin{tabular}{|c|c|c|c|c|c|c|c|c|c|c|c|}
\hline Process / Function & \multicolumn{11}{|c|}{ Scoring Factors } \\
\hline Alternative 2 & $\mathbf{R M}$ & $\overline{P M}$ & EQ & FA & SAFT & PER & SCH & NEPA & ESI & FM1 & FM2 \\
\hline weights & 0.3 & 0.9 & 0.9 & 0.9 & 0.3 & 0.1 & 0.3 & 0.9 & 0.9 & 5.5 & 3.7 \\
\hline $\begin{array}{l}\text { Weld Primary } \\
\text { Shipping Container } \\
\text { (PSC) }\end{array}$ & 3 & 4 & 3 & 5 & 0 & 1 & 2 & 0 & 3 & 2.75 & 3.35 \\
\hline Store in F Canyon & 4 & 2 & 0 & 0 & 0 & 0 & 0 & 0 & 1 & 0.71 & 0.81 \\
\hline Ship to ORNL & 8 & 9 & 10 & 5 & 10 & 1 & 6 & $\overline{6}$ & 6 & 7.22 & 7.81 \\
\hline Store at ORNL & 10 & 6 & 1 & 7 & 10 & 0 & 4 & 2. & 10 & 5.56 & 5.35 \\
\hline & & & & & & & & & & & \\
\hline $\begin{array}{l}\text { max of } \\
\text { above: }\end{array}$ & 10 & 9 & 10 & 7 & 10 & 1 & 6 & 6 & 10 & 8 & 10 \\
\hline
\end{tabular}

Typical maturity period (years)

Need Date

Evaluation Date

Years till needed

Schedule Consequence
3.4

$5 / 1 / 99$

$3 / 3 / 98$

1.16

0.7

Schedule Risk
0.55 


\section{Appendix L}

\subsubsection{Tank 17.1 "Solution" Disposition - Alternative Three}

\begin{tabular}{|c|c|c|c|c|c|c|c|c|c|c|c|}
\hline \multirow{2}{*}{$\begin{array}{l}\text { Process / Function } \\
\text { Alternative } 3\end{array}$} & \multicolumn{11}{|c|}{ Scoring Factors } \\
\hline & RM & $\mathbf{P M}$ & $\mathrm{EQ}$ & $\mathbf{F A}$ & SAFT & PER & SCH & NEPA & ESI & FMI & FM2 \\
\hline weights & 0.3 & 0.9 & 0.9 & 0.9 & 0.3 & 0.1 & 0.3 & 0.9 & 0.9 & 5.5 & 3.7 \\
\hline & & & & & & 7 & & & & & \\
\hline $\begin{array}{l}\text { Weld Contamination } \\
\text { Can }\end{array}$ & 3 & 4 & 3 & 5 & 0 & 1 & 2 & 0 & 3 & 2.75 & 3.35 \\
\hline Store in F Canyon & 4 & 2 & 0 & 0 & 0 & 0 & 0 & 0 & 1 & 0.71 & 0.81 \\
\hline $\begin{array}{l}\text { Mechanical Seal in } \\
\text { SSC }\end{array}$ & 0 & 0 & 0 & 0 & 0 & 0 & 0 & 0 & 0 & 0.00 & 0.00 \\
\hline Ship to ORNL & 8 & 9 & 10 & 5 & 10 & 1 & 6 & 6 & 6 & 7.22 & 7.81 \\
\hline Store at ORNL & 10 & 6 & 1 & 7 & 10 & 0 & 4 & 2 & 10 & 5.56 & 5.35 \\
\hline & & & & & & & & & & & \\
\hline $\begin{array}{l}\max \text { of } \\
\text { above: }\end{array}$ & 10 & 9 & 10 & 7 & 10 & 1 & 6 & 6 & 10 & & $78 \times 19$ \\
\hline
\end{tabular}

Typical maturity period (years) Need Date

Evaluation Date Years till needed

Schedule Consequence
3.4

$5 / 1 / 99$ $3 / 3 / 98$

1.16
Process will be mature in 42 . years

Schedule Risk

\subsubsection{Tank 17.1 "Solution" Disposition - Alternative Four}

\begin{tabular}{|c|c|c|c|c|c|c|c|c|c|c|c|}
\hline Process / Function & \multicolumn{11}{|c|}{ Scoring Factors } \\
\hline Alternative 4 & $\mathrm{RM}$ & PM & EQ & FA & SAFT & PER & SCH & NEPA & ESI & FM1 & FM2 \\
\hline weights & 0.3 & 0.9 & 0.9 & 0.9 & 0.3 & 0.1 & 0.3 & 0.9 & 0.9 & 5.5 & 3.7 \\
\hline $\begin{array}{l}\text { Weld Contamination } \\
\text { Can }\end{array}$ & 3 & 4 & 3 & 5 & 0 & 1 & 2 & 0 & 3 & 275 & 3.35 \\
\hline Store in F Canyon & 4 & 2 & 0 & 0 & 0 & 0 & 0 & 0 & 1 & 0.71 & 0.81 \\
\hline Ship to L Basin & 1 & 3 & 2 & 0 & 0 & 0 & 1 & 0 & 1 & 1.09 & 1.38 \\
\hline Store in Dry Storage & 4 & 6 & 6 & 10 & 10 & 1 & 4 & 10 & 6 & 7.22 & 6.84 \\
\hline Ship to ORNL & 8 & 9 & 10 & 5 & 10 & 1 & 6 & 6 & 6 & 7.22 & 7.81 \\
\hline Store at ORNL & 10 & 6 & 1 & 7 & 10 & 0 & 4 & 2 & 10 & 5.56 & 5.35 \\
\hline & & & & & & & & & & & \\
\hline $\begin{array}{l}\max \text { of } \\
\text { above: }\end{array}$ & 10 & 9 & 10 & 10 & 10 & 1 & 6 & 10 & 10 & & 78 \\
\hline
\end{tabular}

Typical maturity period (years) Need Date Evaluation Date Years till needed Schedule Consequence
3.4

$5 / 1 / 99$ $3 / 3 / 98$

1.16

0.7
Process will be mature in 4.7 .

Schedule Risk

0.62 


\section{Appendix $L$}

\subsubsection{Tank 17.1 "Solution" Disposition - Alternative Five}

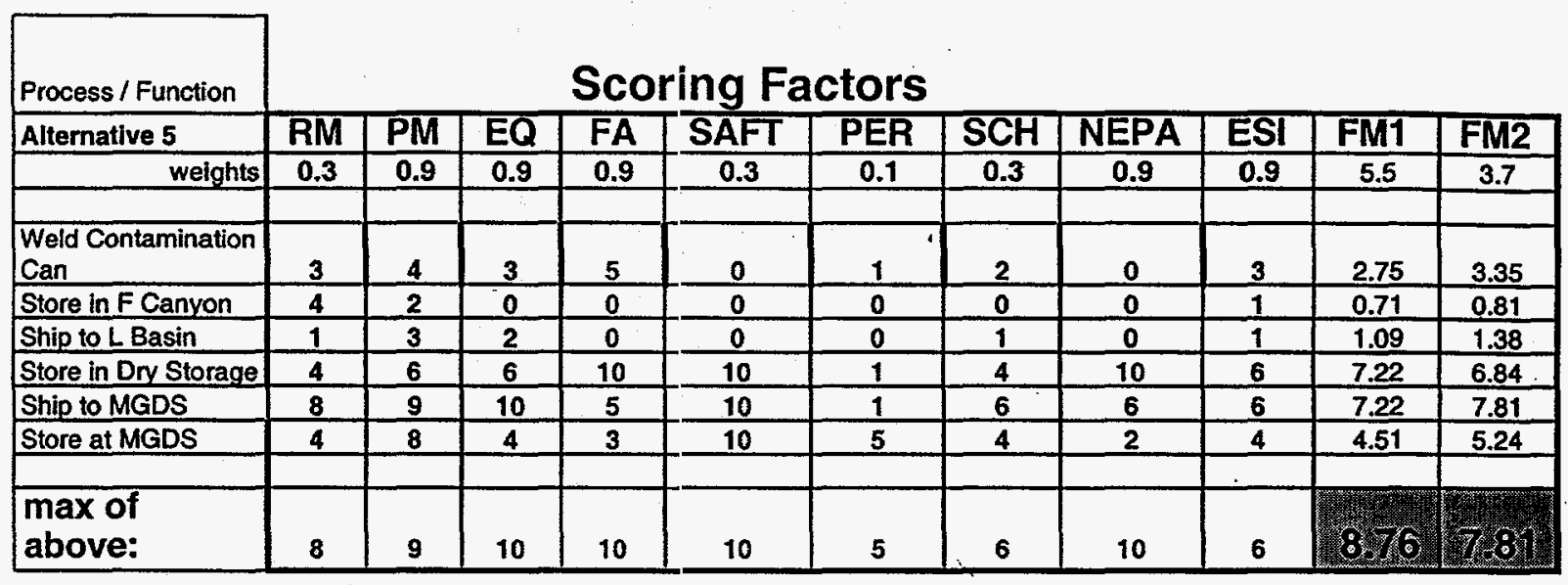

\author{
Typical maturity period (years) \\ Need Date \\ Evaluation Date \\ Years till needed \\ Schedule Consequence
}

3.4

5/1/99 Process will be mature in 4.4 . $3 / 3 / 98$

1.16

0.7

Schedule Risk

0.58

\subsubsection{Mark 18s Disposition - Base Alternative}

\begin{tabular}{|c|c|c|c|c|c|c|c|c|c|c|c|}
\hline Process / Function & \multicolumn{11}{|c|}{ Scoring Factors } \\
\hline Base Case & $\mathbf{R M}$ & $\mathbf{P I M}$ & EQ & $\mathbf{F A}$ & SAFT & PER & SCH & NEPA & ESI & FMT & FM2 \\
\hline weights & 0.3 & 0.9 & 0.9 & 0.9 & 0.3 & 0.1 & 0.3 & 0.9 & 0.9 & 5.5 & 3.7 \\
\hline & & & & & & & & & & & \\
\hline Unpack Mk 18 & 8 & 9 & 9 & 7 & 10 & 3 & $\overline{4}$ & $\overline{8}$ & 8 & 7.96 & 7.95 \\
\hline Cut Mk 18 & 8 & 9 & 9 & 7 & 10 & 3 & 4 & 8 & 8 & 7.96 & 7.95 \\
\hline $\begin{array}{l}\text { Mech. Seal in } \\
\text { canister }\end{array}$ & 3 & 2 & 0 & 3 & 0 & 0 & 0 & 0 & 2 & 1.31 & 1.46 \\
\hline Ship to ORNL & 6 & 6 & 10 & 0 & 8 & 0 & 4 & 10 & 6 & 6.22 & 5.35 \\
\hline Store at ORNL & 10 & 6 & 1 & 7 & 10 & 0 & 4 & 10 & 10 & 6.87 & 5.35 \\
\hline & & & & & & & & & & & \\
\hline $\begin{array}{l}\text { max of } \\
\text { above: }\end{array}$ & 10 & 9 & 10 & 7 & 10 & 3 & 4 & 10 & 10 & $3: 9$ & 35 \\
\hline
\end{tabular}

\footnotetext{
Typical maturity period (years) Need Date Evaluation Date Years till needed Schedule Consequence
}

\section{4 3/3/98 \\ 0.66}

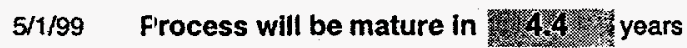

\subsection{9}




\section{Appendix L}

\subsubsection{Mark 18s Disposition - Base Alternative One}

\begin{tabular}{|c|c|c|c|c|c|c|c|c|c|c|c|}
\hline Process / Function & \multicolumn{11}{|c|}{ Scoring Factors } \\
\hline Alternative 1 & RM & PM & EQ & FA & SAFT & PER & SCH & NEPA & ESI & FM1 & FM2 \\
\hline weights & 0.3 & 0.9 & 0.9 & 0.9 & 0.3 & 0.1 & 0.3 & 0.9 & 0.9 & 5.5 & 3.7 \\
\hline & & & & & & & & & & & \\
\hline Load in CD cask* & 0 & 0 & 0 & 0 & 0 & 0 & 0 & 0 & 0 & 0.00 & 0.00 \\
\hline Ship to F-Canyon* & 0 & 0 & 0 & 0 & 0 & 0 & 0 & 0 & 0 & 0.00 & 0.00 \\
\hline Unload CD cask* & 0 & 0 & 0 & 0 & 0 & 0 & 10 & 0 & 0 & 0.00 & 0.00 \\
\hline Dissolve Mk $18 \mathrm{~s}$ & 4. & 6 & 6 & 5 & 8 & 0 & 2 & 8 & 4 & 5.51 & 5.27 \\
\hline Glass Feed Prep** & 0 & 0 & 0 & 0 & 0 & 0 & 0 & 0 & 0 & 0.00 & 0.00 \\
\hline Make Glass"* & 0 & 0 & 0 & 0 & 0 & 0 & 0 & 0 & 0 & 0.00 & 0.00 \\
\hline $\begin{array}{l}\text { Glass Canister } \\
\text { functions }{ }^{* *}\end{array}$ & 0 & 0 & 0 & 0 & 0 & 0 & 0 & 0 & 0 & 0.00 & 0.00 \\
\hline Ship to ORNL & 8 & 9 & 10 & 5 & 10 & 1 & 6 & 6 & 6 & 7.22 & 7.81 \\
\hline Store at ORNL & 10 & 6 & 1 & 7 & 10 & 0 & 4 & 10 & 10 & 6.87 & 5.35 \\
\hline & & & & & & & & & & & \\
\hline $\begin{array}{l}\max \text { of } \\
\text { above: }\end{array}$ & 10 & 9 & 10 & 7 & 10 & 1 & 6 & 10 & 10 & 896 & 78 \\
\hline
\end{tabular}

\author{
Typical maturity period (years) \\ Need Date \\ Evaluation Date \\ Years till needed \\ Schedule Consequence
}

\section{4 \\ $5 / 1 / 99$ \\ $3 / 3 / 98$ \\ 1.16 \\ 0.7}

Process will be mature in 1 Ther 4.5 .

Schedule Risk

0.59

\subsubsection{Tank 17.1 "Solution" Disposition - DPM Evaluation Summary}

The Technical Maturity Analysis for the six Am/Cm "solution" alternatives is summarized in the below Table. DPM calculates a disposition path maturity including NEPA and ESI for an alternative. DPM' calculates the maximum step TM excluding NEPA and ESI for each step. By inspection, it is quickly obvious that the Base Case has the lowest individual step maturity, since it is most like current operations. Alternatives two through five, which all employ welding in MPPF have similar maximum step technical maturity's driven by shipping out of either F canyon or a new Spend Fuel facility (with NEPA and ESI excluded because they should be essentially the same for the paths). Welding underwater in RBOF presents a significantly greater challenge. Note that there is almost no difference in schedule consequence (CS) and schedule risk (Risk) between the alternatives based on the NMI methodology.

\section{Am/Cm Solution Technical Maturity Analysis}

\begin{tabular}{|l|c|c|c|c|}
\hline Alternative & DPM & DPM' & CS & Risk \\
\hline Base Case & 7.71 & 5.35 & 0.67 & 0.52 \\
\hline Alternative 1 & 8.35 & 8.35 & 0.66 & 0.55 \\
\hline Alternative 2 & 8.31 & 7.81 & 0.66 & 0.55 \\
\hline Alternative 3 & 8.31 & 7.81 & 0.66 & 0.55 \\
\hline Alternative 4 & 9.45 & 7.81 & 0.66 & 0.62 \\
\hline Alternative 5 & 8.76 & 7.81 & 0.66 & 0.58 \\
\hline
\end{tabular}




\section{Appendix $L$}

The table below shows the comparison between the two Mark 18 alternatives. The Disposition Path Maturity evaluated by the NMI methodology shows essentially no difference in Technical Maturity, schedule consequence or schedule risk. However, the maximum technical maturity for each step shows Alternative 1 as slightly higher in technical maturity (7.81 vs. 7.95$)$ than the base case.

\section{Mk-18 Technical Maturity Analysis}

\begin{tabular}{|l|c|c|c|c|}
\hline Alternative & DPM & DPM' & CS & Risk \\
\hline Base Case & 8.89 & 7.95 & 0.66 & 0.59 \\
\hline Alternative 1 & 8.96 & 7.81 & 0.66 & 7.81 \\
\hline
\end{tabular}

The table below shows a comparison of five of the six solution technical maturities without ORNL storage included. Technical maturities increased slightly, but were not strongly driven by ORNL storage.

\section{Am/Cm Solution Technical Maturity Analysis} (Without ORNL Storage)

\begin{tabular}{|l|c|c|c|c|}
\hline Alternative & DPM & DPM' & CS & Risk \\
\hline Base Case & 7.05 & 5.35 & 0.67 & 0.47 \\
\hline Alternative 1 & 8.56 & 8.35 & 0.66 & 0.56 \\
\hline Alternative 2 & 7.55 & 7.81 & 0.66 & 0.50 \\
\hline Alternative 3 & 7.55 & 7.81 & 0.66 & 0.50 \\
\hline Alternative4 & 8.69 & 7.81 & 0.66 & 0.57 \\
\hline
\end{tabular}

Similar behavior for the two Mark 18 alternatives is shown in the next table.

\section{Mk-18 Technical Maturity Analysis (without ORNL Storage)}

\begin{tabular}{|l|c|c|c|c|}
\hline Alternative & DPM & DPM $^{\prime}$ & CS & Risk \\
\hline Base Case & 8.45 & 7.95 & 0.66 & 0.56 \\
\hline Alternative 1 & 7.55 & 7.81 & 0.66 & 0.59 \\
\hline
\end{tabular}

\subsubsection{Programmatic Risk Assessments}

The Fall 1997, EM 2006 Plan required programmatic risk assessments for each Site's critical closure path. Table 8.0 in the EM 2006 Plan Guidance document describes the 3 Programmatic Risk Categories. These programmatic risk categories have been adopted for use by the NMI Project to help discriminate between alternative disposition paths. As part of this study, a programmatic risk assessment was performed for each baseline and alternative disposition path.

Criteria used for these assessments are summarized in the tables below: 


\section{Appendix L}

\begin{tabular}{|c|c|c|c|}
\hline $\begin{array}{l}\text { Programmatic } \\
\text { Risk } \\
\text { Categories } \\
\end{array}$ & Technology & Work Scope Definition & Inter-Site Dependency \\
\hline 5 (high) $^{*}$ & $\begin{array}{l}\text { I. No technology to accomplish the } \\
\text { planned activity has been found to } \\
\text { exist and no technology is under } \\
\text { development. } \\
\text { II. The identified STCG Need is listed } \\
\text { in Table O.9.2. }\end{array}$ & $\begin{array}{l}\text { I. Project end state is not determined or } \\
\text { supported by stakeholders or Tribal Nations } \\
\text { II. Waste/material quantities and } \\
\text { characteristics are unknown } \\
\text { III. Process operations are not identified or } \\
\text { supported by stakeholders or Tribal Nations } \\
\text { IV. Final disposition location for waste/materia } \\
\text { has not been identified }\end{array}$ & $\begin{array}{l}\text { 1. Activity involves multiple sites } \\
\text { II. No concurrence has been reacheo } \\
\text { between sites }\end{array}$ \\
\hline $4^{*}$ & $\begin{array}{l}\text { I. A potential technology has been } \\
\text { identified to accomplish the } \\
\text { planned activity, but development } \\
\text { is only at the laboratory scale level } \\
\text { or earlier, } \\
\text { II. The identified STCG Need is listed } \\
\text { in Table O.9.2. }\end{array}$ & $\begin{array}{l}\text { I. Project end state is determined but may be } \\
\text { controversial to stakeholders or Tribal } \\
\text { Nations } \\
\text { II. Process operations are identified, but may } \\
\text { be controversial to stakeholders or Tribal } \\
\text { Nations } \\
\text { III. Final disposition location for waste/materia } \\
\text { has not been identified and approved }\end{array}$ & $\begin{array}{l}\text { 1. Activity involves multiple sites, site } \\
\text { concurrence has been verbally } \\
\text { reached } \\
\text { II. The Waste Acceptance Criteria } \\
\text { (WAC) has not been resolved } \\
\text { III. No funding has been identified and } \\
\text { no schedule for receipt or } \\
\text { treatment of the waste/material } \\
\text { exists }\end{array}$ \\
\hline $3^{*}$ & $\begin{array}{l}\text { I. A potential technology has been } \\
\text { identified to accomplish the } \\
\text { planned activity, and is being } \\
\text { demonstrated at least at a pilot } \\
\text { scale level. } \\
\text { II. The identified STCG Need is listed } \\
\text { in Table O.9.2. }\end{array}$ & $\begin{array}{l}\text { 1. Project end state is determined and is } \\
\text { expected to be acceptable to stakeholders } \\
\text { or Tribal Nations } \\
\text { II. Waste/material quantities and } \\
\text { characteristics are broadly known } \\
\text { III. Process operations are identified and are } \\
\text { expected to be acceptable to stakeholders } \\
\text { or Tribal Nations } \\
\text { IV. Final disposition location for waste/material } \\
\text { has been identified and ElS is being } \\
\text { prepared }\end{array}$ & $\begin{array}{l}\text { I. Activity impacts another site, site } \\
\text { concurrence has been verbally } \\
\text { reached } \\
\text { II. Receiving facility is reviewing } \\
\text { characterization data to determing } \\
\text { WAC acceptability } \\
\text { III. Funding has been identified but nd } \\
\text { schedule for receipt or treatment } \\
\text { of the waste/material exists }\end{array}$ \\
\hline $2^{*}$ & $\begin{array}{l}\text { I. The required technology has been } \\
\text { fully developed and demonstrated } \\
\text { at another site with a similar } \\
\text { waste/material type }\end{array}$ & $\begin{array}{l}\text { I. Project end state is determined and } \\
\text { supported by stakeholders or Tribal Nations } \\
\text { II. Waste/material quantities and } \\
\text { characteristics are well known } \\
\text { III. Process operations are identified and are } \\
\text { supported by stakeholders or Tribal Nations } \\
\text { IV. Final disposition location for waste/material } \\
\text { has been identified and EIS ROD is } \\
\text { prepared }\end{array}$ & $\begin{array}{l}\text { V. Activity doesn't impact another site } \\
\text { or Site concurrence has been } \\
\text { documented if multiple sites are } \\
\text { impacted } \\
\text { VI. Receiving facility has verified WAd } \\
\text { acceptability } \\
\text { VII. Funding has been identified but no } \\
\text { schedule for receipt or treatment } \\
\text { of the waste/material exists }\end{array}$ \\
\hline $1\left(\right.$ low) ${ }^{*}$ & $\begin{array}{l}\text { 1. Technology has been } \\
\text { demonstrated at the site on some } \\
\text { actual waste/materials and is } \\
\text { operationally ready }\end{array}$ & $\begin{array}{l}\text { I. Project end state is determined and } \\
\text { supported by stakeholders or Tribal Nations } \\
\text { II. Waste/material quantities and } \\
\text { characteristics are well known } \\
\text { II. Process operations are identified and are } \\
\text { supported by stakeholders or Tribal } \\
\text { Nations }\end{array}$ & $\begin{array}{l}\text { 1. Activity doesnit impact another site } \\
\text { or Site concurrence has been } \\
\text { documented if multiple sites } \\
\text { involved } \\
\text { II. Receiving facility has verified WAd } \\
\text { acceptability } \\
\text { III. Funding is identified in an approved } \\
\text { PBS and facility is ready to receive } \\
\text { the waste/material }\end{array}$ \\
\hline
\end{tabular}




\section{Appendix L}

\section{Analysis of Programmatic Risk for Am/Cmn "Solution", Mk 18, and Am/Cm Slug Disposition Alternatives}

The table (and accompanying notes) below indicate evaluated programmatic risk for $\mathrm{Am} / \mathrm{Cm}$ "solution" (Tank 17.1), Mk-18 and slug/other alternatives. It should be noted that for a given material group, there is practically no difference in proposed programmatic risk scores. A large delta does exist when comparing installation of a dissolver in $\mathrm{F}$ Carlyon vs. design/installation of an isolation chamber for RBOF.

\section{Programmatic Risk}

\begin{tabular}{|l|c|c|c|}
\cline { 2 - 4 } \multicolumn{1}{c|}{} & Technology & Work Scope Definition & Inter-Site Dependency \\
\hline Tank 17.1 Base Case & 2 & 4 & 5 \\
\hline Tank 17.1 Alt. 1 & 2 & 4 & 5 \\
\hline Tank 17.1 Alt. 2 & 2 & 4 & 5 \\
\hline Tank 17.1 Alt. 3 & 2 & 4 & 5 \\
\hline Tank 17.1 Alt. 4 & 2 & 4 & 5 \\
\hline Tank 17.1 Alt. 5 & 2 & 4 & 5 \\
\hline
\end{tabular}

\begin{tabular}{|l|l|l|l|}
\hline Mk-18s Base Case & 4 & 4 & 5 \\
\hline Mk-18s Alternative One & 2 & 4 & 5 \\
\hline
\end{tabular}

\begin{tabular}{|l|l|l|l|}
\hline Slug/Other Base Case & 2 & 4 & 5 \\
\hline
\end{tabular}

Notes:

Technology

- Both remote and underwater welding have been demonstrated.

- Both Cs-137 positioning for cutting underwater and Mk-18 dissolution have been conceptualized but not demonstrated.

Work Scope Definition

- EISs or appropriate checklists have not been prepared.

- In the case of Mk 18s and slugs/Other the ROD is scheduled to be issued December 1998. At that time the selected alternatives would drop to a 1 or 2 .

Inter-Site Dependency

- Because of funding and EIS issues, agreement on shipping Tank 17.1 vitrified materials to ORNL is in the very preliminary stages.

- Agreement has been verbally reached to ship "slugs/other and Mark $18 \mathrm{~s}$ to ORNL, but the funding will not be available until after the EISi ROD.

\subsubsection{Am/Cm ES\&H Risk Assessments}

This section provides background information, identifies the factors used as surrogate metrics for potential ES\&H risk for this study.

The approach used in this study was developed to be consistent in format with the Disposition Path Maturity, Programmatic Risk, and Life-Cycle Cost assessments. Given the large number of paths to consider for each category of materials, and the need to address multiple functions per path, an attempt was made to use simple factors, for which information is likely to be readily available, as rough surrogate indicators of potential ES\&H risk. Finally, the approach is based on the large amount of work 


\section{Appendix L}

on NM already conducted by DOE-EH in the preparation of ES\&H vulnerability studies for spent fuel (published in 1993), plutonium (1994), and HEU (1996).

\section{Vulnerability Categories and Risk Criteria Factors}

Of the three categories of vulnerabilities identified in the DOE-EH ES\&H NM studies (material/packaging, facility condition, and institutional/administrative), material/packaging vulnerability factors are used as screening criteria for the NMI project and this study. The facility condition vulnerability factors (e.g., facility structural integrity, safety systems status) and institutional vulnerability factors (e.g., authorization basis status, personnel training and qualification status) are addressed in the Disposition Path Maturity assessment screening process.

The Material Vulnerability Category includes five factors: material characterization; package integrity/condition; material form; mass of material; and material toxicity. For each factor, a description is provided of relatively lower risk and relatively higher risk conditions.

Worker ES\&H risk is also expected to be influenced by the three factors described in the Handling Vulnerability Category. These include factors for: radiological hazard potential;

non-radiological hazard potential; and material handling frequency.

In addition, public ES\&H risk from the routine stabilization and disposition of NM is expected to be driven by transportation risks. The Transportation Vulnerability Category contains a single factor that considers whether off-site shipment of NM will occur. This factor is based on the potential physical trauma related to truck accidents, rather than on radiological exposure. On a national average basis, a physical trauma fatality resulting from a transportation accident is expected to occur every 2.5 million miles of truck travel, irrespective of the cargo shipped. This figure is very conservative, given the expected much lower incidence of shipping accidents for shipments of NM.

\section{Material Vulnerability Category}

1. Material Characterization Factor

- material well characterized; packages accurately labeled, including material limits and spacing requirements -1

- material not well characterized; missing or inaccurate labels, unknown or uncharacterized material $-2$

2. Package Integrity/Condition Factor

- no known deficiencies or degradation in packaging; packages intact and unlikely to be breached during handling accidents - 1

- condition of packaging is unknown; deficiency or degradation of package or container due to aging, corrosion, radiolytic damage, pressurization; package breach during handling accidents possible -

\section{Material Form Factor}

- material is a metal or solid with low leak, spill, dispersion potential - 1

- material is in a powder, oxide, or particulate form (e.g., ash) with intermediate leak, spill, dispersion potential - 2 


\section{Appendix L}

- material is a liquid or gas with high leak, spill, dispersion potential - 3

4. Mass of Material Factor

- amount of material $\leq 1 \mathrm{~g}-1$

- amount of material $>1 \mathrm{~g}<1$ metric ton -2

- amount of material $>1$ metric ton - 3

\section{Material Toxicity Factor}

Based on values for exponents of Derived Air Concentrations (DACs), as presented in Appendix A of 10 CFR 835 (attached). Find isotope of interest in Appendix A tables, and use minimum of available radioisotope-specific $\mathrm{D}, \mathrm{W}, \mathrm{Y}$ values presented (in units of $u \mathrm{Ci} / \mathrm{ml}$ ). For mixed isotopes, use isotope with lowest DAC value.

- DAC exponent range $10^{-1}$ to $10^{-4}-1$

- DAC exponent range $10^{-5}$ to $10^{-9}-2$

- DAC exponent range $10^{-10}$ to $10^{-13}-3$

\section{Handling Vulnerability Category}

6. Radiological Hazard Potential Factor

- mainly manual or contact-handled processing - 1

- mainly remote-handled processing - 2

7. Non-radiological Hazard Potential Factor

- non-energetic process; no hazardous chemicals - 1

- energetic process (e.g., high pressure, temperature; explosive potential); hazardous chemicals (e.g., nitric acid, beryllium) - 2

8. Material Handling Frequency Factor

- $\quad$ single step/pass processing -1

- multiple step/pass processing - 2

\section{Transportation Vulnerability Category}

9.

- no off-site transfer of material - 1

- total number of truck shipments $\mathbf{x}$ number of round-trip miles per shipment $<2.5$ million miles (e.g., multiple local or regional shipments) -2

- total number of truck shipments $x$ number of round-trip miles per shipment $\geq 2.5$ million miles (e.g., multiple cross-country shipments) - 3 


\section{Appendix L}

\section{Guidance Provided for Conducting ES\&H Risk Screening}

For the NMI Project, ES\&H screening will be conducted to: (1) estimate the potential ES\&H vulnerability of the material in its current state; and (2) to compare baseline disposition pathways and alternative pathways.

\section{Material Current State ES\&H Vulnerability Screen}

Material Current State Vulnerability is qualitatively characterized as High, Medium, or Low based on the scores for Factors 1 through 5, as follows:

Factors 1-5 Material Current State Vulnerability is Low if:

- Scores for Factors 1-3 are 1 (irrespective of scores for Factors 4 and 5)

Factors 1-5 Material Current State Vulnerability is High if:

- Scores for Factors 1 and 2 are 2 and Factor 3 are 2 or $3 \underline{A N D}$

Factors 1-5 Material Current State Vulnerability is Medium:

- for all other combinations of Factor scores

\section{Disposition Pathway ES\&H Vulnerability Screen}

For comparison of baseline and alternative disposition pathways, ES\&H vulnerability metrics are:

Handling Vulnerability $=$ sum of scores of Factors $6,7 \& 8$

Transportation Vulnerability $=$ score of Factor 9

ES\&H vulnerability scores are estimated for the each disposition pathway. Material Evaluation Teams should consider the entire disposition pathway in developing scores for Handling Vulnerability Factors 6 through 8 and Transportation Vulnerability Factor 9 . The overall pathway Handling Vulnerability score is the sum of the scores for Factors 6-9. The pathway Transportation Vulnerability score is the score for Factor 9 . These scores will be used to compare baseline disposition pathways with alternative pathways.

Samples of the ES\&H Material Current State Vulnerability Screening Worksheet and the Disposition Pathway Vulnerability Screening Worksheet are attached. 


\section{Appendix L}

\section{ES\&H MATERIAL C,URRENT STATE VULNERABILITY SCREENING WORKSHEET}

\begin{tabular}{|c|c|c|}
\hline $\begin{array}{l}\text { Material Stream ID: } \\
\text { Material Stream Name: } \\
\text { Function: }\end{array}$ & $\begin{array}{l}\text { Factor } \\
\text { Score }\end{array}$ & $\begin{array}{c}\text { Category } \\
\text { Score }\end{array}$ \\
\hline $\begin{array}{l}\text { 1. Material Characterization Factor } \\
\text {-. material well characterized; packages accurately labeled, including } \\
\text { material limits and spacing requirements }-1 \\
\text {-. Material not well characterized; missing or inaccurate labels, } \\
\text { unknown or uncharacterized material or packaging - } 2\end{array}$ & 1 or 2 & \\
\hline $\begin{array}{l}\text { 2. Package Integrity/Condition Factor } \\
\text {-. Packages intact and unlikely to be breached during handling } \\
\text { accidents - } 1 \\
\text {-. Deficiency or degradation of package or container due to aging, } \\
\text { corrosion, radiolytic damage, pressurization; package breach during } \\
\text { handling accidents likely - } 2\end{array}$ & 1 or 2 & \\
\hline $\begin{array}{l}\text { 3. Material Form Factor } \\
\text {-. Material is a metal or solid with low leak, spill, dispersion } \\
\text { potential - } 1 \\
\text { - Material is in a powder, oxide, or particulate form (e.g., ash) with } \\
\text { intermediate leak, spill, dispersion potential - } 2 \\
\text { - Material is a liquid or gas with high leak, spill, dispersion } \\
\text { potential - } 3\end{array}$ & 1,2 or 3 & \\
\hline $\begin{array}{l}\text { 4. Mass of Material Factor } \\
\text { - Amount of material } \leq 1 \mathrm{~g}-1 \\
\text {-Amount of material }>1 \mathrm{~g}<1 \text { metric ton }-2 \\
\text {-. Amount of material }>1 \text { metric ton }-3\end{array}$ & 1,2, or 3 & \\
\hline $\begin{array}{l}\text { 5. Material Toxicity Factor } \\
\text {-. Radioisotope-specific DAC exponent range } 10^{-1} \text { to } 10^{-4}-1 \\
\text {-. Radioisotope-specific DAC exponent range } 10^{-5} \text { to } 10^{-9}-2 \\
\text {-. Radioisotope-specific DAC exponent range } 10^{-10} \text { to } 10^{-13}-3\end{array}$ & 1,2 or 3 & $H, M$, or $L$ \\
\hline
\end{tabular}

Factors 1 - 5: If scores for Factors 1-3 are 1 (irrespective of scores for Factors 4 and 5), Material Current State Fisk is Low

Factors 1 - 5: If: (a) scores for Factor $1 \& 2$ are 2 and scores for Factor 3 are 2 or 3; AND (b) scores for Factor 4 are 2 or 3 OR score for Factor 5 is 3 , Material Current State Risk is High

Factors 1 - 5: Material Current State Flisk for all other combinations of scores is Medium 
Appendix L

\section{ES\&H DISPOSITION PATHWAY VULNERABILITY SCREENING WORKSHEET}

\begin{tabular}{|c|c|c|}
\hline $\begin{array}{l}\text { Material Stream ID: } \\
\text { Material Stream Name: } \\
\text { Function: }\end{array}$ & $\begin{array}{l}\text { Factor } \\
\text { Score }\end{array}$ & $\begin{array}{l}\text { Category } \\
\text { Score }\end{array}$ \\
\hline Material Handling Vulnerability Category & & \\
\hline $\begin{array}{l}\text { 6. Radiological Hazard Potential Factor } \\
\text {-. contact-handled processing }-1 \\
\text { - remote-handled processing }-2\end{array}$ & 1 or 2 & \\
\hline $\begin{array}{l}\text { 7. Non-radiological Hazard Potential Factor } \\
-\quad \text { non-energetic process; no hazardous chemicals - } 1 \\
\bullet \quad \text { energetic process; hazardous chemicals - } 2\end{array}$ & 1 or 2 & \\
\hline $\begin{array}{l}\text { 8. Material Handling Frequency Factor } \\
\text {-. single step/pass processing }-1 \\
\text {-. multiple step/pass processing }-2\end{array}$ & 1 or 2 & Sum \\
\hline Transportation Vulnerability Category & & \\
\hline $\begin{array}{l}\text { 9. Material Shipment Factor } \\
\text {-. no off-site transfer of material - } 1 \\
\text {-. Total number of truck shipments } x \text { number of round-trip miles per } \\
\text { shipment }<2.5 \text { million miles - } 2 \\
\text {-. Total number of truck shipments } x \text { number of round-trip miles per } \\
\text { shipment } \geq 2.5 \text { million miles - } 3\end{array}$ & & 1,2, or 3 \\
\hline
\end{tabular}


Appendix L

\section{Am/Cm ES\&H Risk Evaluation}

The table below indicates the proposed scores for the $\mathrm{Am} / \mathrm{Cm}$ "solution, Mark-18 and Am/Cm slug alternatives. It should be noted that there is no expected difference in scores for a base case and alternatives for a given material.

\begin{tabular}{|c|c|c|c|c|c|c|c|c|c|}
\hline & \multicolumn{5}{|c|}{ Material Vulnerability Category } & \multicolumn{3}{|c|}{ Handling Vulnerability } & \multirow[t]{2}{*}{$\begin{array}{c}\text { Transportation } \\
\text { Vulnerability }\end{array}$} \\
\hline & $\begin{array}{c}\text { Material } \\
\text { Characterization }\end{array}$ & $\begin{array}{l}\text { Package } \\
\text { Integrity }\end{array}$ & $\begin{array}{c}\text { Material } \\
\text { Form } \\
\end{array}$ & $\begin{array}{c}\text { Material } \\
\text { Mass }\end{array}$ & $\begin{array}{l}\text { Material } \\
\text { Toxicity }\end{array}$ & $\begin{array}{c}\text { Rad. Hazard } \\
\text { Potential }\end{array}$ & $\begin{array}{c}\text { Non-Rad. } \\
\text { Hazard } \\
\text { Potential }\end{array}$ & $\begin{array}{c}\text { Material } \\
\text { Handling } \\
\text { Frequency }\end{array}$ & \\
\hline Tank 17.1 Base Case & 1 & 1 & 1 & 2 & TBD & 2 & 1 & 2 & 2 \\
\hline Tank 17.1 Alt. 1 & 1 & 1 & 1 & 2 & TBD & 2 & 1 & 2 & 2 \\
\hline Tank 17.1 Alt: 2 & 1 & 1 & 1 & 2 & TBD & 2 & 1 & 2 & 2 \\
\hline Tank 17.1 Alt. 3 & 1 & 1 & 1 & 2 & TBD & 2 & 1 & 2 & 2 \\
\hline \begin{tabular}{|l} 
Tank 17.1 Alt. 4 \\
\end{tabular} & 1 & 1 & 1 & 2 & TBD & 2 & 1 & 2 & 2 \\
\hline Tank 17.1 Alt. 5 & 1 & 1 & 1 & 2 & TBD & 2 & 1 & 2 & 2 \\
\hline Mk-18s Base Case & 1 & 1 & 1 & 1 & TBD & 2 & 1 & 2 & 2 \\
\hline Mk-18s Alternative One & 1 & 1 & 1 & 1 & TBD & 2 & 1 & 2 & 2 \\
\hline Slug/Other Base Case & 1 & 1 & 1 & 1 & TBD & 2 & $\overline{1}$ & 2 & 2 \\
\hline
\end{tabular}




\section{Appendix L}

\subsubsection{Disposition Path Evaluation Summary}

\section{Alternative Cost Evaluation}

Costs were evaluated for the six Am/Cm solution alternatives and the two Mk 18 alternatives for preparing the material for shipment and shipping it to ORNL. Since the estimated $\$ 80 \mathrm{M}$ cost for the Am/ $/ \mathrm{Cm}$ glass project and the $\$ 7 \mathrm{M}$ ORNL storage project were common costs, they were not included. These costs are summarized in the table below:

\begin{tabular}{|l|c|c|c|c|}
\hline Case & $\begin{array}{c}\text { Prepare to } \\
\text { ship }\end{array}$ & Ship & Total & Avg. \\
\hline Tank 17.1 Solution & $1.9-2.0$ & $2.7-3.5$ & $4.6-5.5$ & 5 \\
\hline Tank 17.1 Sol. Alt 1 & $3.2-3.4$ & $2.7-3.5$ & $5.9-6.9$ & 6.4 \\
\hline Tank 17.1 Sol. Alt 2 & 1.7 & $2.7-3.5$ & $4.4-5.2$ & 4.8 \\
\hline Tank 17.1 Sol. Alt 3 & 1.3 & $2.7-3.5$ & $4-4.8$ & 4.4 \\
\hline Tank 17.1 Sol. Alt 4 & $2.8-3.4$ & $2.7-3.5$ & $5.5-6.9$ & 6.2 \\
\hline Tank 17.1 Sol. Alt 5 & $14.5-55.8$ & $1.9-2.0$ & $16.3-57.8$ & 37.1 \\
\hline & & & & \\
\hline Mk-18 Base & 15 & 2 & 17 & 17 \\
\hline Mk-18 Alt 1 & $6.7-7.7$ & 0.4 & $7.1-8.1$ & 7.6 \\
\hline & & & & \\
\hline Slugs \& Other & 1 & 0 & 1 & 1 \\
\hline
\end{tabular}

Since these are planning level costs, i.e. $-50 \% /+100 \%$ there is no large difference between alternatives, with the exception of disposition as waste, Tank 17.1 Alternative 5

\section{Decision Analysis}

Since there was no difference between alternatives for Programmatic Risk and ES\&H risk, for this type of analysis it is customary to eliminate these two factors from further consideration. Without any additional information decision analysis would consider cost and technical maturity equal. If we calculate a cost and DPM' ratio where:

$$
\begin{gathered}
\text { Cost Ratio }=\text { Alternative Cost/sum(Alternative Costs) } \\
\text { and } \\
\text { DPM Ratio }=\text { DPM(Alternative)/sum(DPM(Alternatives)) }
\end{gathered}
$$

Then we can define a Score that yields a higher score for more attractive alternatives:

$$
\text { Score }=1-(\text { Cost Ratio + DPM Ratio })^{\star} 0.5
$$

The table below gives the calculated scores for the six $\mathrm{Am} / \mathrm{Cm}$ solution alternatives and two Mk 18 alternatives: 


\section{Appendix L}

\begin{tabular}{|l|c|c|c|}
\hline Am/Cm Solution & & \\
\hline Alternative & Cost Ratio & DPM Ratio & Score \\
\hline Base Case & 0.078 & 0.152 & 0.885 \\
\hline Alternative 1 & 0.100 & 0.164 & 0.868 \\
\hline Alternative 2 & 0.075 & 0.163 & 0.881 \\
\hline Alternative 3 & 0.069 & 0.163 & 0.884 \\
\hline Alternative 4 & 0.097 & 0.186 & 0.859 \\
\hline Alternative 5 & 0.580 & 0.172 & 0.624 \\
\hline Mk-18 & & & \\
\hline Base Case & 0.725 & 0.501 & 0.387 \\
\hline Alternative 1 & 0.275 & 0.499 & 0.613 \\
\hline
\end{tabular}

In addition to this analysis the following pros and cons were developed to look at the alternatives:

Am/Cm "Solution" Base Case

$+$

$+$

$-$

$-$

-
No Pu curie content limit for system (no waivers required) Off-site casks shipped from RBOF (no "decon shed" required) Increases shipping from RBOF -- not in current schedule Increases CWP-1 handling Full penetration weld qualification required

\section{Am/Cm "Solution" Alternative One}

$+$

$+$

$-$

$-$

Am/Cm "Solution" Alternative Two

Am/Cm "Solution" Alternative Three

$\begin{array}{ll}+ & \text { Minimizes CwP-2 handling } \\ + & \text { No impact on RBOF shipping } \\ - & \text { Requires waivers for shipping } \\ - & \text { Potential CwP-2 decontamination difficulties } \\ - & \text { Requires nEw F-Canyon procedures for commercial } \\ & \text { Am/Cm "Solution" Alternative Four } \\ + & \text { Does not require ORNL storage addition } \\ + & \text { No impact cn RBOF shipping } \\ + & \text { Requires no waiver for shipping } \\ - & \text { Requires new facilities in L Reactor area } \\ - & \text { Requires transport machine to load cask storage }\end{array}$

No Pu curie content limit for system (no waivers required)

Minimizes CWP-1 handling

No impact on RBOF shipping

Full penetration weld qualification required

Requires new F-Canyon procedures for commercial cask

Minimizes CiwP-2 handling

No impact on RBOF shipping

Requires waivers for shipping

Potential CwP-2 decontamination difficulties

Requires new F-Canyon procedures for commercial cask/decon shed

$\mathrm{Am} / \mathrm{Cm}$ "Solution" Alternative Four

No impact on RBOF shipping

Requires new facilities in L Reactor area

Requires transport machine to load cask storage 


\section{Appendix L}

Am/Cm "Solution" Alternative Five

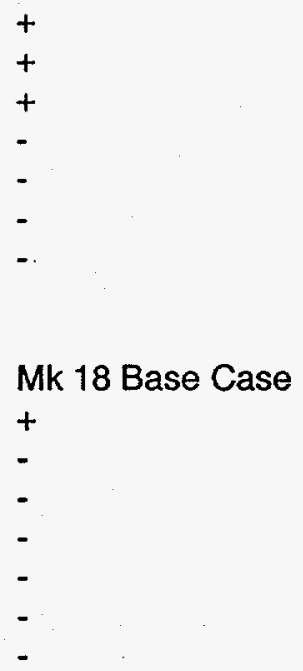

Mk 18 Alternative One

$$
+
$$$$
+
$$$$
+
$$$$
+
$$$$
+
$$$$
-
$$

\section{Slugs Base Case}

\section{$+$}

Does not require ORNL storage addition

No impact on RBOF shipping

Requires no waiver for shipping

Requires new facilities in L Reactor area

Requires transport machine to load cask storage

Requires sampling, qualification and analysis of the glass

Some risk of making material that is not acceptable to the repository

No Aqueous processing/canyon modifications required

Untested equipment required to reduce Mk 18 size

Potential significant RBOF airborne and water contamination

Larger number of shipments (33)

Larger impact on ORNL storage

Different material from $\mathrm{Am} / \mathrm{Cm}$ Solution to be handled at ORNL

Requires Mk 42 processing completion to make space available

Produces glass form like "Solution"

Some preliminary design available

Minimizes number of shipments (8-10)

Minimizes impact on ORNL Storage

Minimum impact on RBOF operations

Requires canyon Modifications and aqueous processing

NOTE: May be able to use existing F Canyon facilities, equipment

and personnel, this would have a significant impact on decreasing costs, schedules and risks.

Minimal RBOF impact

Requires no canyon processing

Requires shipping package analysis 


\section{Appendix M}

\subsection{Appendix M-Disposition Path Maturity Evaluation Score Basis}

\subsubsection{Tank 17.1 "Solution" - Base Alternative}

MPPF Primary, RBOF Secondary Containment, Shipped from RBOF to ORNL

\subsubsection{Function 1: Make Glass}

The function "Make Glass" was not evaluated based on the assumption that the current program will meet the scope, cost, and schedules provided in this report.

\subsubsection{Function 1: Weld CwP-1}

\begin{tabular}{|c|c|c|c|c|c|}
\hline $\begin{array}{l}\text { Tank } 17.1 \text { Solution - Base } \\
\text { Alternative - Glass }\end{array}$ & $\begin{array}{l}\text { FUNCTIO } \\
\text { Weld Cw! }\end{array}$ & N: 1 in MPP & /F-Cany & & \\
\hline Scale & & Weight & Score & Final & Rationalization \\
\hline Requirements Maturity & $\overline{\mathrm{H}} \overline{\mathrm{M}}$ & $\overline{0 . \overline{3}}$ & 3 & $\bar{y}$ & $\begin{array}{l}\text { Remote weiding has been done. Not a new technoiogy. Littie chang } \\
\text { in requirements expected }\end{array}$ \\
\hline Processing \& Storage Maturity: & PM & 0.9 & 4 & 3.6 & Process has been done cold at PNL. \\
\hline Transportation Process Maturitit & TPM & 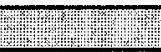 & 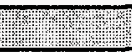 & 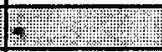 & 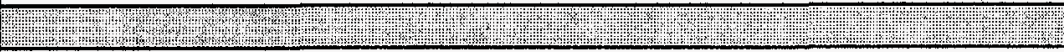 \\
\hline $\begin{array}{l}\text { Process \& Storage Hardware } \\
\text { Equipment Maturity }\end{array}$ & $E Q$ & 0.9 & $\overline{3}$ & 2.7 & Prototype has been done on site \\
\hline $\begin{array}{l}\text { Transportation Hardware } \\
\text { Equipment Maturity }\end{array}$ & TEQ & 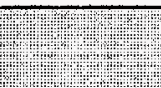 & 涪 & 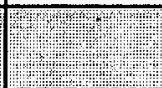 & 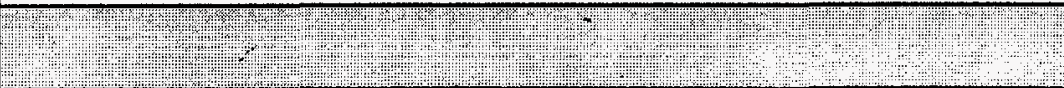 \\
\hline Facility Equipment Readiness & FAC & 0.9 & 5 & 4.5 & Requires moderate modifications will be required \\
\hline Operational Safety Readiness & SAFT & 0.3 & 0 & 0 & $\begin{array}{l}\text { Making glass and welding canisters within the facility authorization } \\
\text { basis. }\end{array}$ \\
\hline Personal Resource Status & PER & 0.1 & $\overline{1}$ & .1 & $\begin{array}{l}\text { Time is available, training is relatively simple and operators are } \\
\text { currently trained in remote operations }\end{array}$ \\
\hline Schedule Maturity & $\mathrm{SCH}$ & 0.3 & 2 & .6 & $\begin{array}{l}\text { Welding glass canisters within MPPF/F-Canyon is conceptual. Input } \\
\text { is from experienced personnel using engineering judgment to } \\
\text { extrapolate. }\end{array}$ \\
\hline NEPA Readiness & NEPA & 0.9 & 0 & 0 & ROD presently covers welding in F-Canyon \\
\hline $\begin{array}{l}\text { End State System Interface } \\
\text { Requirements }\end{array}$ & ESI & 0.9 & 3 & 2.7 & ORNL has bounded the design. Detail design remains to be done. \\
\hline
\end{tabular}




\section{Appendix M}

9.13.1.2. Transport to RBOF

\begin{tabular}{|c|c|c|c|c|c|}
\hline $\begin{array}{c}\text { Tank } 17.1 \text { Solution - Base } \\
\text { Alternative - Glass }\end{array}$ & \multicolumn{4}{|c|}{$\begin{array}{l}\text { FUNCTION: } \\
\text { Transport to RBOF }\end{array}$} & \\
\hline Scale & & Weight & Score & Final & Rationalization \\
\hline Requirements Maturity & RM & 0.3 & 1 & .3 & $\begin{array}{l}\text { Tasks utilizes on-site cask and will follow existing WSRC } 19 Q \\
\text { requirements. Calculation is incomplete for contents of cask. }\end{array}$ \\
\hline Processing \& Storage Maturity & $\mathrm{PMN}$ & 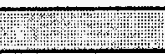 & 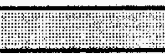 & 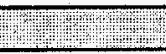 & (1) \\
\hline Transportation Process Maturity & TPM & 0.9 & 2 & 1.8 & Tasks has been performed but not recently. \\
\hline $\begin{array}{l}\text { Process \& Storage flardware } \\
\text { Equipment Maturity }\end{array}$ & 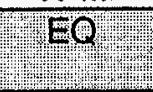 & & & & 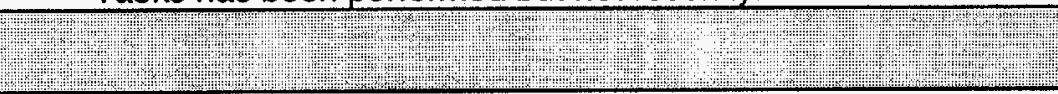 \\
\hline $\begin{array}{l}\text { Transportation Hardware } \\
\text { Equipment Maturity }\end{array}$ & TEQ & 0.9 & 2 & 1.8 & $\begin{array}{l}\text { Tasks has been performed but not with this material }(N) \text { or } \\
\text { basket. Shipping Mk } 18 \text { was done under old requirements. } \\
\text { Calculation has to be done. Equipment is available. }\end{array}$ \\
\hline Facility Equipment Readiness & FAC & 0.9 & 0 & 0 & Facility is on a continued operating basis. \\
\hline Operational Safety Readiness & SAFT & 0.3 & 0. & 0 & USQ required but obtainable within one year. \\
\hline Personal Resource Status & PER & 0.1 & 0 & 0 & Personnel available and transfers in progress. \\
\hline Schedule Maturity & $\mathrm{SCH}$ & 0.3 & 2 & 0.6 & CwP-1 concept only; schedule from experienced professionals \\
\hline NEPA Readiness & NEPA & 0.9 & 0 & 0 & Requires NEPA Checklist. \\
\hline $\begin{array}{l}\text { End State System Interface } \\
\text { Requirements }\end{array}$ & ESI & 0.9 & $\overline{1}$ & .9 & Tool to handle insert has not been built \\
\hline
\end{tabular}




\section{Appendix M}

9.13.1.3. Store in RBOF

\begin{tabular}{|c|c|c|c|c|c|}
\hline $\begin{array}{l}\text { Tank } 17.1 \text { Solution - } \\
\text { Base Alternative - Glass }\end{array}$ & & $\begin{array}{l}\text { CTION: } \\
\text { In RBOF }\end{array}$ & & & \\
\hline Scale & & Weight & Score & Final & Rationalization \\
\hline Requirements Maturity & RM & 0.3 & 6 & 1.8 & $\begin{array}{l}\text { Glass project has not determined how many canisters will be } \\
\text { generate but does know a range. }\end{array}$ \\
\hline Processing \& Storage Maturity: & PM & 0.9 & 2 & 1.8 & CwP-1 is a slightly different in form. \\
\hline Transportation Process Maturit & TPM & & 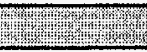 & 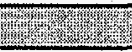 & (n) \\
\hline $\begin{array}{l}\text { Process \& Storage Hardware } \\
\text { Equipment Maturity }\end{array}$ & EQ & 0.9 & 1 & .9 & New tools may be required \\
\hline $\begin{array}{l}\text { Transportation Hardware- } \\
\text { Equipment Maturity }\end{array}$ & TEQ & ang & & 膈 & \\
\hline Facility Equipment Readiness & FAC & 0.9 & 0 & 0 & Facility is presently storing radioactive material \\
\hline Operational Safety Readiness & $\overline{\mathrm{SAFT}}$ & 0.3 & 2 & .6 & Bounded in Authorization Basis pending analysis. \\
\hline Personal Resource Status & PER & 0.1 & 0 & 0 & Personnel available and operations in progress. \\
\hline Schedule Maturity & $\mathrm{SCH}$ & 0.3 & 2 & .6 & Number of containers to be stored has a range but is not yet detailed \\
\hline NEPA Readiness & NEPA & 0.9 & 0 & 0 & ROD presently covers RBOF operation \\
\hline $\begin{array}{l}\text { End State System Interface } \\
\text { Requirements }\end{array}$ & ESI & 0.9 & 4 & $\overline{3.6}$ & Need to know criticality number dose rates, sizes. \\
\hline
\end{tabular}

Requirements 
Appendix M

\subsubsection{Ship to ORNL via RBOF}

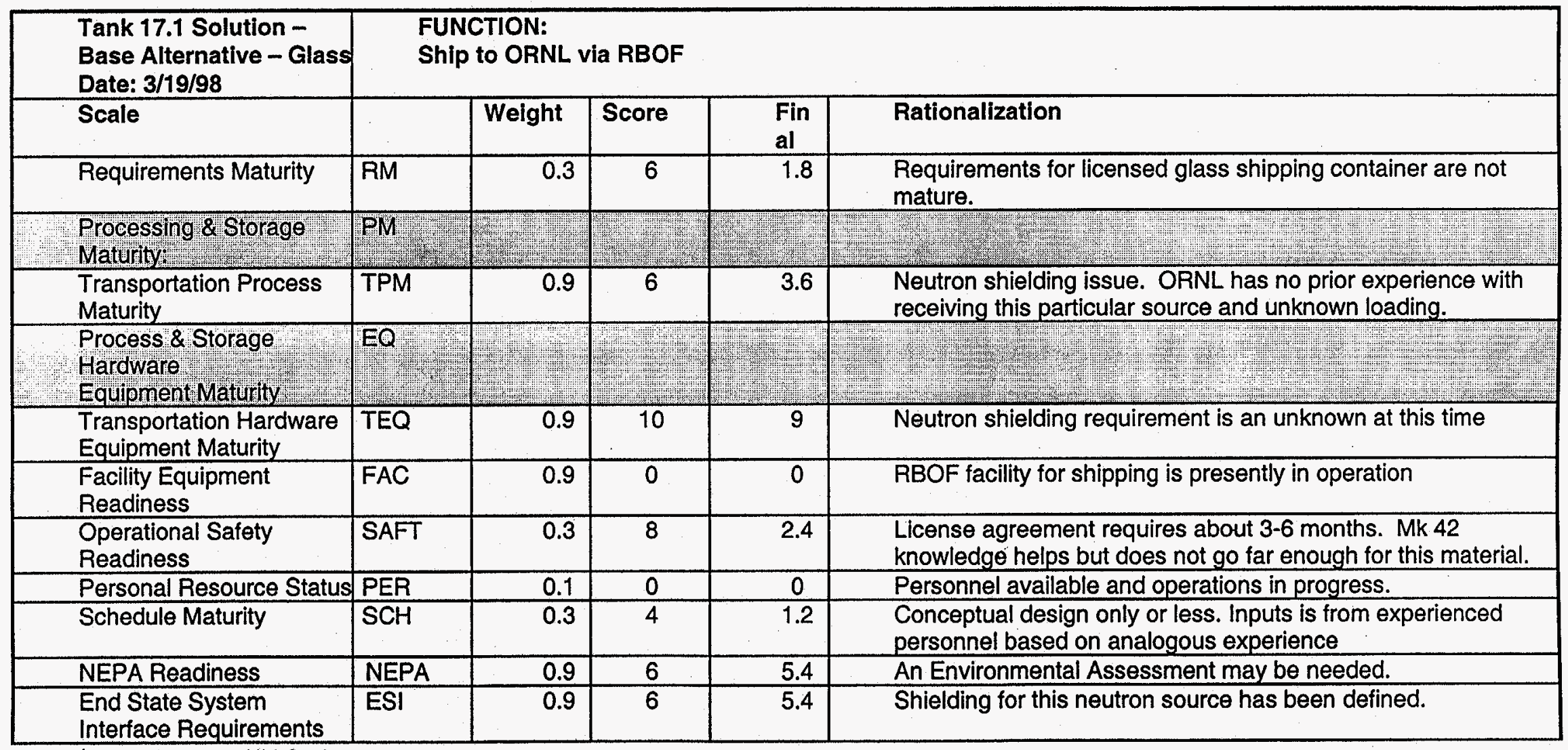

Note: Assumes Nul Cask 


\section{Appendix M}

9.13.1.5. Store at ORNL.

\begin{tabular}{|c|c|c|c|c|c|}
\hline $\begin{array}{l}\text { Tank } 17.1 \text { Solution - } \\
\text { Base Alternative - Glass }\end{array}$ & $\begin{array}{l}\text { FUN } \\
\text { Stor }\end{array}$ & $\begin{array}{l}\text { CTION: } \\
\text { at ORNL }\end{array}$ & & & \\
\hline Scale & & Weight & Score & Final & Rationalization \\
\hline Requirements Maturity & $\overline{\mathrm{RM}}$ & 0.3 & 10 & 3 & $\begin{array}{l}\text { Mission has volatility in that it is not approved and adds storage } \\
\text { to ORNL. }\end{array}$ \\
\hline $\begin{array}{l}\text { Processing \& Storage } \\
\text { Maturity: }\end{array}$ & PM & 0.9 & 6 & 5.4 & $\begin{array}{l}\text { Design is conceptual. Storage of highly radioactive material is } \\
\text { feasible. Cooling may be an issue. }\end{array}$ \\
\hline $\begin{array}{l}\text { Transportation Process } \\
\text { Maturity }\end{array}$ & TPM & & & & 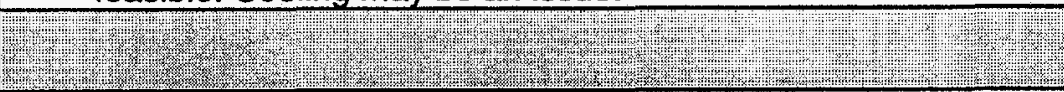 \\
\hline $\begin{array}{l}\text { Process \& Storage } \\
\text { Hardware } \\
\text { Equipment Maturity }\end{array}$ & $E Q$ & 0.9 & 1 & .9 & $\begin{array}{l}\text { Heat load design is only conceptual. Modifications must be } \\
\text { made. Cooling design and build in } 2-3 \text { years }\end{array}$ \\
\hline $\begin{array}{l}\text { Transpotatiof Hardwere } \\
\text { Equipment Maturity }\end{array}$ & 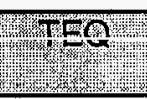 & 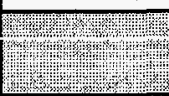 & & & 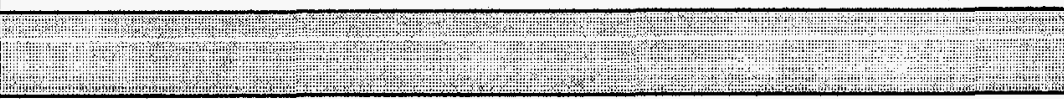 \\
\hline $\begin{array}{l}\text { Facility Equipment } \\
\text { Readiness }\end{array}$ & FAC & 0.9 & 7 & 6.3 & Little room available without additional modification. \\
\hline $\begin{array}{l}\text { Operational Safety } \\
\text { Readiness }\end{array}$ & SAFT & 0.3 & 10 & 3 & Modification required and hazard classification will change. \\
\hline Personal Resource Status & PER & 0.1 & 0 & 0 & Personnel available in ongoing operations. \\
\hline Schedule Maturity & $\overline{\mathrm{SCH}}$ & 0.3 & 4 & 1.2 & $\begin{array}{l}\text { Conceptual design only or less. Inputs is from experienced } \\
\text { personnel based on analogous experience }\end{array}$ \\
\hline NEPA Readiness & NEPA & 0.9 & 2 & 1.8 & ORNL handles Am/Cm feedstocks; EA or less required \\
\hline $\begin{array}{l}\text { End State System } \\
\text { Interface Requirements }\end{array}$ & ESI & 0.9 & 10 & 9 & ORNL needs to look at EIS and talk to internal personnel. \\
\hline
\end{tabular}

\subsubsection{ORNL Operations}

The "Make Products", "Use Products", "Recycle Products" and "Dispose of Products" are ORNL Operations and are outside the scope of this study. 


\section{Appendix M}

\subsubsection{Tank 17.1 "Solution" - Alternative \#1}

MPPF Contamination Control Can, RBOF Primary \& Secondary Containment, Shipped from RBOF to ORNL

9.13.2.1. Make Glass (Refer to Section 9.13.1.1)

\subsubsection{Transport to RBOF (Refer to Section 9.13.1.3)}

9.13.2.3. Weld CWP-3 in RBOF

\begin{tabular}{|c|c|c|c|c|c|}
\hline \multirow{2}{*}{$\begin{array}{l}\text { Tank } 17.1 \text { Solution - } \\
\text { Alternative \#1 - Glass } \\
\text { Date 3/19/98 } \\
\text { Scale }\end{array}$} & \multicolumn{5}{|c|}{$\begin{array}{l}\text { FUNCTION: } \\
\text { Weld CWP-3 RBOF }\end{array}$} \\
\hline & & Weight & Score & Final & Rationalization \\
\hline Requirement Maturity & RM & 0.3 & 8 & 2.4 & Remote welding has not been done in RBOF. \\
\hline Processing \& Storage Maturit & PM & 0.9 & 9 & 8.1 & $\begin{array}{l}\text { Design is conceptual at best, but underwater welding has been } \\
\text { done. }\end{array}$ \\
\hline $\begin{array}{l}\text { Transportation Plocess } \\
\text { Maturity }\end{array}$ & TPMP & 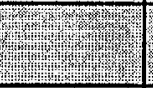 & 28 & & \\
\hline $\begin{array}{l}\text { Process \& Storage Hardware } \\
\text { Equipment Maturity }\end{array}$ & $E Q$ & 0.9 & 10 & 9 & All equipment requirements are not yet defined \\
\hline $\begin{array}{l}\text { Transportation Merardware } \\
\text { Equipment Maturity }\end{array}$ & TEQ & & & & 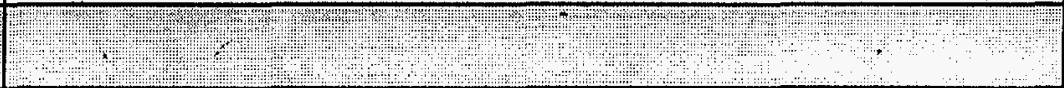 \\
\hline Facility Equipment Readines & SFAC & 0.9 & 7 & 6.3 & $\begin{array}{l}\text { Impact to NIMs due OT power surges. Welder has to be } \\
\text { seismically qualified. New equipment will be placed into system. }\end{array}$ \\
\hline Operational Safety Readines: & SSAFT & 0.3 & 10 & 3.0 & ORR required. Will be a major modification \\
\hline Personal Resource Status & PER & 0.1 & 3 & 0.3 & Significant training required, not on critical path. \\
\hline Schedule Maturity & $\mathrm{SCH}$ & 0.3 & 6 & 1.8 & $\begin{array}{l}\text { Design is conceptual or less. Experienced personnel using } \\
\text { Engineering judgment to extrapolate. }\end{array}$ \\
\hline NEPA Readiness & NEPA & 0.9 & 0 & 0 & $\begin{array}{l}\text { Would have to do a NEPA Checklist to prove we are bounded. } \\
\text { Expectation is that it is covered }\end{array}$ \\
\hline $\begin{array}{l}\text { End State System Interface } \\
\text { Requirements }\end{array}$ & ESI & 0.9 & 8 & 7.2 & Other than a mission exists, nothing else is known. \\
\hline
\end{tabular}




\section{Appendix M}

9.13.2.4. Mechanically Seal msQSC

\begin{tabular}{|c|c|c|c|c|c|}
\hline $\begin{array}{l}\text { Tank } 17.1 \text { Solution - } \\
\text { Alternative \#1 - Glass }\end{array}$ & \multicolumn{3}{|c|}{$\begin{array}{l}\text { FUNCTION: } \\
\text { Mechanically Seal msQSC }\end{array}$} & & \\
\hline Scale & & Weight & Score & Final & Rationalization \\
\hline Requirement Maturity & $\mathrm{RM}$ & 0.3 & 3 & 0.9 & $\begin{array}{l}\text { Operation is similar to cask closure which is a normal RBOF } \\
\text { function }\end{array}$ \\
\hline Processing \& Storage Maturit & y $\mathrm{PM}$ & 0.9 & 2 & 1.8 & Similar operations have been performed. \\
\hline $\begin{array}{l}\text { Transportation Process } \\
\text { Maturity }\end{array}$ & PPM & 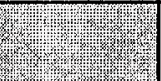 & 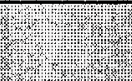 & 0.0 & 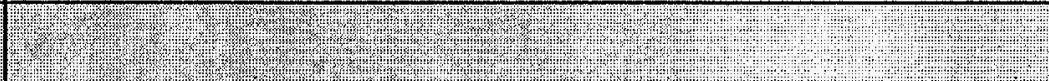 \\
\hline $\begin{array}{l}\text { Process \& Storage Hardware } \\
\text { Equipment Maturity }\end{array}$ & $E Q$ & 0.9 & 0 & 0.0 & Equipment has been used for comparable operations. \\
\hline $\begin{array}{l}\text { Transportation Hardware } \\
\text { Equipment Maturity }\end{array}$ & TEQ & & 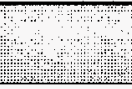 & 0.0 & \\
\hline Facility Equipment Readines\$ & FAC & 0.9 & 3 & 2.7 & Minor modifications will be required. \\
\hline Operational Safety Readiness & SAFT & 0.3 & 0 & 0.0 & Task should be within Authorization Basis. \\
\hline Personal Resource Status & PER & 0.1 & 0 & 0.0 & $\begin{array}{l}\text { Personnel are available in ongoing production. Only minor } \\
\text { training required. }\end{array}$ \\
\hline Schedule Maturity & $\mathrm{SCH}$ & 0.3 & $\overline{0}$ & 0.0 & $\begin{array}{l}\text { Function falls within scope of normal operational capability. } \\
\text { Schedule inputs are from experienced personnel on analogous } \\
\text { experience }\end{array}$ \\
\hline NEPA Readiness & NEPA & 0.9 & 0 & 0.0 & Falls under an existing EIS. \\
\hline $\begin{array}{l}\text { End State System Interface } \\
\text { Requirements }\end{array}$ & ESI & 0.9 & 2 & 1.8 & Verification testing will have to be performed. \\
\hline
\end{tabular}

9.13.2.5. Store in RBOF (Refer to Section 9.13.1.4

9.13.2.6. Ship to ORNL via RBOF (Refer to Section 9.13.1.5)

9.13.2.7. Store at ORNL (Refer to Section 9.13.1.6) 


\section{Appendix M}

\subsubsection{Tank 17.1 "Solution" - Alternative \#2}

MPPF Primary - Cask Secondary Containment, Shipped for F-Canyon to ORNL

\subsubsection{Make Glass (Refer to Section 9.13.1.1)}

\subsubsection{Weld CwP-1 in MPPF/F-Canyon (Refer to Section 9.13.1.2)}

\subsubsection{Store in F-Canyon}

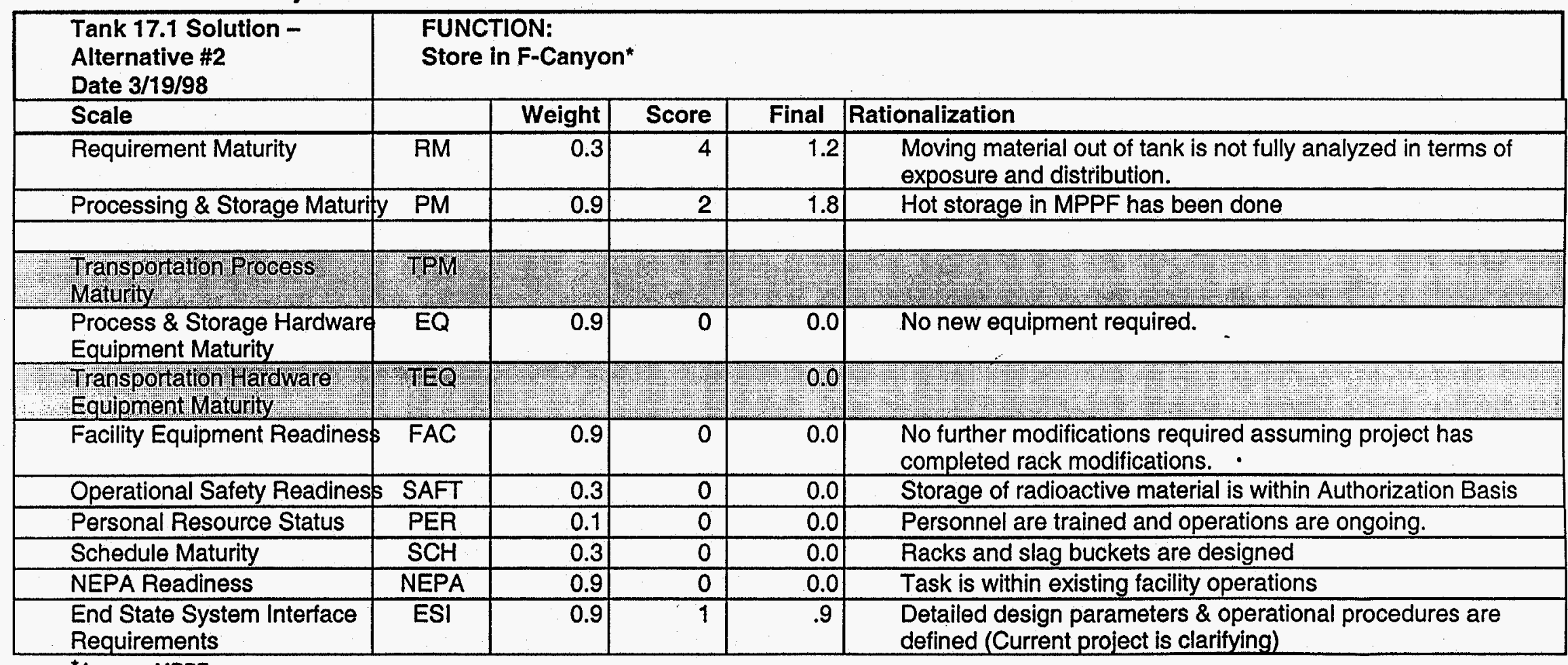

*Assume MPPF 


\section{Appendix M}

9.13.3.4. Ship to ORNL via F-Canyon

\begin{tabular}{|c|c|c|c|c|c|}
\hline $\begin{array}{l}\text { Tank } 17.1 \text { Solution - } \\
\text { Alternative \#2 }\end{array}$ & \multicolumn{5}{|c|}{$\begin{array}{l}\text { FUNCTION: } \\
\text { Ship to ORNL via F-Canyon* }\end{array}$} \\
\hline Scale & & Weight & Score & Final & Rationalization \\
\hline Requirements Maturity & RM & 0.3 & 8 & 2.4 & $\begin{array}{l}\text { Direct shipping from F-Canyon to ORNL for this application ha } \\
\text { never been done (off-site shipping cask has not been brought } \\
\text { into railroad tunnel). Requirements for licensed glass shipping } \\
\text { container are not mature. }\end{array}$ \\
\hline Processing \& Storage Materity: & $P M$ & II: & +4 & $=1$ & 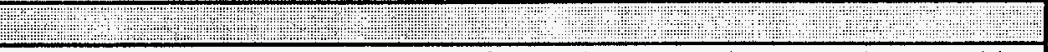 \\
\hline Transportation Process Maturity & TPM & 0.9 & 9 & 8.1 & $\begin{array}{l}\text { Neutron shielding issue. ORNL has no prior experience with } \\
\text { receiving this particular source and unknown loading. Design } \\
\text { concept and technology application formulated. }\end{array}$ \\
\hline $\begin{array}{l}\text { Process \& Storage Hardware: } \\
\text { Equipment Matufity }\end{array}$ & EQ & & & & ans \\
\hline $\begin{array}{l}\text { Transportation Hardware } \\
\text { Equipment Maturity }\end{array}$ & TEQ & 0.9 & 10 & 9 & $\begin{array}{l}\text { Commercially made but requires modification. Neutron } \\
\text { shielding is an issue. }\end{array}$ \\
\hline Facility Equipment Readiness & FAC & 0.9 & 5 & & $\begin{array}{l}\text { F-Canyon facility is available but needs contamination control } \\
\text { building for cask decontamination and storage. }\end{array}$ \\
\hline Operational Safety Readiness & SAFT & 0.3 & 10 & & $\begin{array}{l}\text { ORR is required. Mk } 42 \text { knowledge helps but does not go far } \\
\text { enough for this material. }\end{array}$ \\
\hline Personal Resource Status & PER & 0.1 & 1 & & $\begin{array}{l}\text { Personnel available and operations in progress. Minor training } \\
\text { would be required. }\end{array}$ \\
\hline Schedule Maturity & $\mathrm{SCH}$ & 0.3 & 6 & & $\begin{array}{l}\text { Conceptual design only or less. Inputs is from experienced } \\
\text { personnel using engineering experience to extrapolate. }\end{array}$ \\
\hline NEPA Readiness & NEPA & 0.9 & 6 & & An EA is believed to be needed. \\
\hline $\begin{array}{l}\text { End State System Interface } \\
\text { Requirements }\end{array}$ & ESI & 0.9 & 6 & & $\begin{array}{l}\text { System description is complete and applicability of the } \\
\text { requirement is understood. }\end{array}$ \\
\hline
\end{tabular}

- Note: Assumes NLI Cask

\subsubsection{Store at ORNL (Refer to 9.13.1.6)}


Appendix M

\subsubsection{Tank 17.1 "Solution" - Alternative \#3}

MPPF Contamination Can - Shipping Cask Primary Containment, Ship From F-Canyon to ORNL

9.13.4.1. Make Glass (Refer to Section 9.13.1.1)

9.13.4.2. Weld CwP-2 in MPPF/F-Canyon (Refer to Section 9.13.2.3)

9.13.4.3. Store in F-Canyon (Refer to Section 9.13.3.3)

9.13.4.4. Ship to ORNL via F-Canyon (Refer to Section 9.13.3.4)

9.13.4.5. Store at ORNL (Refer to Section 9.13.1.6) (refer to Section 9.13.1.6)

9.13.5. Tank 17.1 "Solution" - Alternative \#4

Interim SRS Glass Storage, Transfer to ORNL as Needed

9.13.5.1. Make Glass (refer to Section 9.13.1.1)

9.13.5.2. Weld Cwp-2 in MPPF/F Canyon (Refer to Section 9.13.1.2)

9.13.5.3. Store in F Canyon (Refer to Section 9.13.3.2)

9.13.5.4. Ship to L Basin (Refer to Section 9.13.1.3; Transport to RBOF) 


\section{Appendix M}

9.13.5.5. Store in Dry Storage

\begin{tabular}{|c|c|c|c|c|c|}
\hline $\begin{array}{l}\text { Tank } 17.1 \text { Solution - } \\
\text { Alternative \#4 - Interim }\end{array}$ & \multicolumn{5}{|c|}{$\begin{array}{l}\text { FUNCTION: } \\
\text { Store Containers at L Reactor Dry Storage }\end{array}$} \\
\hline Scale & & Weight & Score & Final & Rationalization \\
\hline Requirements Maturity & $\overline{R M}$ & 0.3 & 4 & 1.2 & $\begin{array}{l}\text { Flowsheet impact understood. Most driving performance } \\
\text { parameters have "first pass" values }\end{array}$ \\
\hline $\begin{array}{l}\text { Processing \& Storage } \\
\text { Maturity: }\end{array}$ & PM & 0.9 & 6 & 5.4 & Hot feasibility demonstrated on similar materials (SNF) \\
\hline $\begin{array}{l}\text { Transportation Process } \\
\text { Maturity }\end{array}$ & TPM & 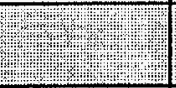 & & & 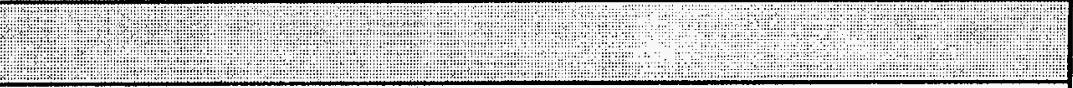 \\
\hline $\begin{array}{l}\text { Process \& Storage } \\
\text { Hardware } \\
\text { Equipment iviaiurity }\end{array}$ & $\mathrm{EQ}$ & 0.9 & 6 & 5.4 & $\begin{array}{l}\text { Commercially designed units in use for SNF. Modifications may } \\
\text { be required. }\end{array}$ \\
\hline $\begin{array}{l}\text { Transpooffation wardware } \\
\text { Equipment Maturity }\end{array}$ & 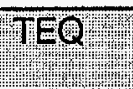 & 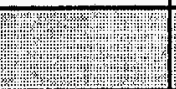 & 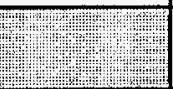 & & 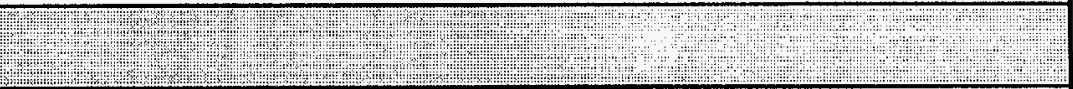 \\
\hline $\begin{array}{l}\text { Facility Equipment } \\
\text { Readiness }\end{array}$ & FAC & 0.9 & 10 & 9 & No facility available (Concrete cask pad cask storage) \\
\hline $\begin{array}{l}\text { Operational Safety } \\
\text { Readiness }\end{array}$ & SAFT & 0.3 & 10 & 3 & ORR Required \\
\hline Personal Resource Status & PER & 0.1 & 1 & 0.1 & $\begin{array}{l}\text { Sufficient frained personnel available, but not trained in this } \\
\text { activity }\end{array}$ \\
\hline Schedule Maturity & $\mathrm{SCH}$ & 0.3 & 4 & 1.2 & $\begin{array}{l}\text { Design is conceptual; schedule based on analogous experience } \\
\text { with experienced personnel. }\end{array}$ \\
\hline NEPA Readiness & NEPA & 0.9 & 2 & 1.8 & Requires EA \\
\hline $\begin{array}{l}\text { End State System } \\
\text { Interface Requirements }\end{array}$ & ESI & 0.9 & 6 & 5.4 & $\begin{array}{l}\text { System description is complete and applicability understood; } \\
\text { most parameter values are unquantified. }\end{array}$ \\
\hline
\end{tabular}

9.13.5.6. Ship to ORNL (Refer to Section 9.13.1.5)

9.13.5.7. Store at ORNL (Refer to Section 9.13.1.6) 
Appendix M

\subsubsection{Tank 17.1 "Solution" - Alternative \#5:}

Treat Glass to Waste

9.13.6.1. Make Glass (refer to Section 9.13.1.1)

9.13.6.2. Prepare for Disposition (refer to Section 9.13.3.2; Weld CWP-2 in MPPF/f Canyon)

9.13.6.3. Ship to L Basin (refer to Section 9.13.1.3; Transport to RBOF)

9.13.6.4. Load Glass CwP-2 in SNF Canister

\begin{tabular}{|c|c|c|c|c|c|}
\hline \multicolumn{6}{|c|}{$\begin{array}{l}\text { FUNCTION: } \\
\text { Load CWP-2 in SNF Canister }\end{array}$} \\
\hline Scale & & Weight & Score & Final & Rationalization \\
\hline Requirements Maturity & RM & 0.3 & 8 & 2.4 & System concept only \\
\hline $\begin{array}{l}\text { Processing \& Storage } \\
\text { Maturity: }\end{array}$ & PM & 0.9 & 6 & 5.4 & $\begin{array}{l}\text { Flow sheet description and applicability of this component } \\
\text { understood }\end{array}$ \\
\hline $\begin{array}{l}\text { Transportation Process } \\
\text { Maturity }\end{array}$ & TPMT & Ply & 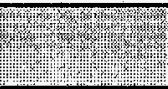 & & 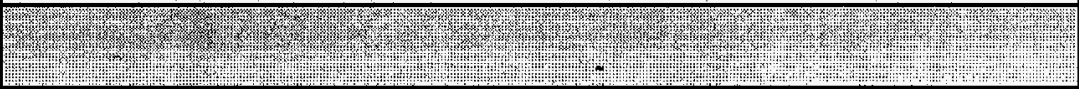 \\
\hline $\begin{array}{l}\text { Process \& Storage } \\
\text { Hardware } \\
\text { Equipment Maturity }\end{array}$ & $E Q$ & 0.9 & 9 & 8.1 & New desigńn, conceptualized \\
\hline $\begin{array}{l}\text { Transportafion Hardware } \\
\text { Equipment Maturity }\end{array}$ & TEQ & 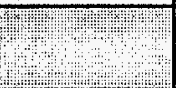 & (2) & & ( \\
\hline $\begin{array}{l}\text { Facility Equipment } \\
\text { Readiness }\end{array}$ & $\overline{F A C}$ & 0.9 & 7 & 6.3 & $\begin{array}{l}\text { L Reactor process area is available and under consideration for } \\
\text { SNF packaging activities }\end{array}$ \\
\hline $\begin{array}{l}\text { Operational Safety } \\
\text { Readiness }\end{array}$ & SAFT & 0.3 & 10 & 3.0 & ORR Required \\
\hline Personal Resource Status & PER & 0.1 & 1 & .1 & $\begin{array}{l}\text { Sufficient trained personnel but not involved in this specific } \\
\text { activity }\end{array}$ \\
\hline Schedule Maturity & $\mathrm{SCH}$ & 0.3 & 6 & 1.8 & $\begin{array}{l}\text { Conceptual design; schedule extrapolated by experienced } \\
\text { personnel }\end{array}$ \\
\hline NEPA Readiness & NEPA & 0.9 & 0 & 0 & NEPA checklist required \\
\hline $\begin{array}{l}\text { End State System } \\
\text { Interface Requirements }\end{array}$ & ESI & 0.9 & 8 & 7.2 & System concept formulated only \\
\hline
\end{tabular}


9.13.6.5. Ship to Repository

\begin{tabular}{|c|c|c|c|c|c|}
\hline \multirow{2}{*}{$\begin{array}{l}\text { Tank } 17.1 \text { Solution - } \\
\text { Alternative \#5 - Treat to } \\
\text { Waste } \\
\text { Date: } 4 / 17 / 98 \\
\text { Scale }\end{array}$} & \multicolumn{5}{|c|}{$\begin{array}{l}\text { FUNCTION: } \\
\text { Ship Containers to MGDS }\end{array}$} \\
\hline & & Weight & Score & Final & Rationalization \\
\hline Requirements Maturity & RM & 0.3 & 6 & 1.8 & $\begin{array}{l}\text { Requirements for licensed glass shipping container are not } \\
\text { mature. }\end{array}$ \\
\hline $\begin{array}{l}\text { Processing \& Storage } \\
\text { Maturity }\end{array}$ & PMI & 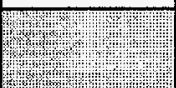 & 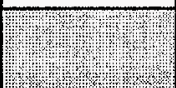 & 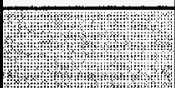 & 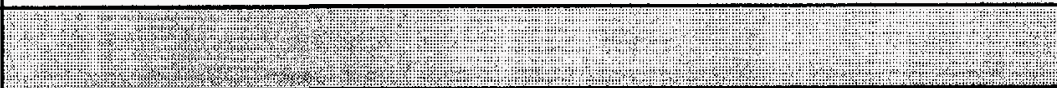 \\
\hline $\begin{array}{l}\text { Transportation Process } \\
\text { Maturity }\end{array}$ & TPM & 0.9 & 7 & 5.6 & $\begin{array}{l}\text { Neutron shielding issue. MGDS has no prior experience with } \\
\text { receiving this particular source and loading. }\end{array}$ \\
\hline $\begin{array}{l}\text { Process \& Storage } \\
\text { rareware } \\
\text { Equipment Maturity }\end{array}$ & EQ & & & & 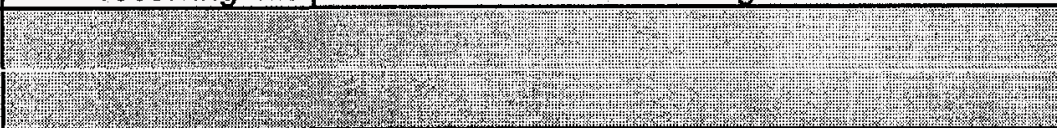 \\
\hline $\begin{array}{l}\text { Transportation Hardware } \\
\text { Equipment Maturity }\end{array}$ & TEQ & 0.9 & 10 & 9 & Neutron shielding requirement is unknown at this time. \\
\hline $\begin{array}{l}\text { Facility Equipment } \\
\text { Readiness }\end{array}$ & FAC & 0.9 & 10 & 9 & $\begin{array}{l}\text { Shipping capability to be provided by SNF transfer facility (in L } \\
\text { Reactor) }\end{array}$ \\
\hline $\begin{array}{l}\text { Operational Safety } \\
\text { Readiness }\end{array}$ & SAFT & 0.3 & 8 & $\overline{2.4}$ & $\begin{array}{l}\text { License agreement requires about 3-6 months. Mk- } 42 \\
\text { knowledge helps but does not go far enough with this material }\end{array}$ \\
\hline Personal Resource Status & PER & 0.1 & 1 & .1 & Personnel available, but no operations currently \\
\hline Schedule Maturity & $\mathrm{SCH}$ & 0.3 & 4 & 1.2 & $\begin{array}{l}\text { Conceptual design only or less; input is from experienced } \\
\text { personnel based on analogous experience. }\end{array}$ \\
\hline NEPA Readiness & NEPA & 0.9 & 10 & 9 & Not covered in existing EIS \\
\hline $\begin{array}{l}\text { End State System } \\
\text { Interface Requirements }\end{array}$ & ESI & 0.9 & 6 & 5.4 & Shielding for this neutron source has not been defined \\
\hline
\end{tabular}




\section{Appendix M}

9.13.6.6. Store at Repository

\begin{tabular}{|c|c|c|c|c|c|}
\hline $\begin{array}{l}\text { Tank } 17.1 \text { Solution - } \\
\text { Alternative \#5 - Treat to }\end{array}$ & \multicolumn{5}{|c|}{$\begin{array}{l}\text { FUNCTION: } \\
\text { Store Containers at MGDS }\end{array}$} \\
\hline Scale & & Weight & Score & Final & Rationalization \\
\hline Requirements Maturity & RM & 0.3 & 4 & 1.2 & $\begin{array}{l}\text { Repository requirements currently in draft form. Repository } \\
\text { basis awaits NRC acceptance }\end{array}$ \\
\hline $\begin{array}{l}\text { Processing \& Storage } \\
\text { Maturity: }\end{array}$ & PM & $\overline{0.9}$ & 8 & 7.2 & Repository cold testing demonstrated (for heat removal) \\
\hline $\begin{array}{l}\text { Transportation Process } \\
\text { Maturity }\end{array}$ & TPM & 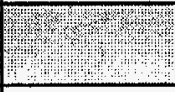 & & & 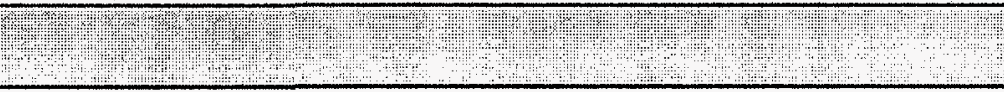 \\
\hline $\begin{array}{l}\text { Process \& Storage } \\
\text { Hardware } \\
\text { Equipment Maturity }\end{array}$ & $\overline{E Q}$ & 0.9 & 4 & 3.6 & Cold testing essentially complete at MGDS \\
\hline $\begin{array}{l}\text { Transportation Hardware } \\
\text { Equipment Maturity }\end{array}$ & TEQ & 30 & 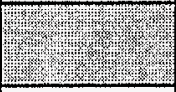 & 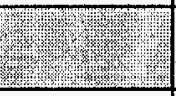 & 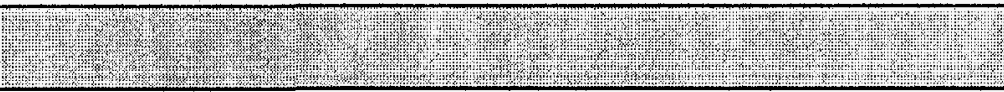 \\
\hline $\begin{array}{l}\text { Facility Equipment } \\
\text { Readiness }\end{array}$ & FAC & 0.9 & 3 & 2.7 & $\begin{array}{l}\text { Heat load may effect repository spacing; Neutron dose may } \\
\text { effect surface handling. }\end{array}$ \\
\hline $\begin{array}{l}\text { Operational Safety } \\
\text { Readiness }\end{array}$ & SAFT & $\overline{0.3}$ & 10 & 3 & ORR required for Repository \\
\hline Personal Resource Status & PER & 0.1 & 5 & 0.5 & Repository is not staffed \\
\hline Schedule Maturity & $\mathrm{SCH}$ & 0.3 & 4 & 1.2 & $\begin{array}{l}\text { Conceptual design only or less. Input is from experience } \\
\text { personnel based on analogous experience. }\end{array}$ \\
\hline NEPA Readiness & NEPA & 0.9 & 2 & 2 & MGDS handles SNF; EA or less required \\
\hline $\begin{array}{l}\text { End State System } \\
\text { Interface Requirements }\end{array}$ & ESI & 0.9 & 4 & 3.6 & $\begin{array}{l}\text { Most Repository design factors analyzed. Specific analysis } \\
\text { would be required for long term release }\end{array}$ \\
\hline
\end{tabular}




\subsection{7. "Mark 18s" - Base Alternative}

Cut Mk 18's in RBOF Basin and Ship to ORNL

9.13.7.1. Unpack Mk 18 Package for CD Cask in RBOF

\begin{tabular}{|c|c|c|c|c|c|}
\hline $\begin{array}{l}\text { Mk } 18 \text { Disposition - } \\
\text { Base Alternative }\end{array}$ & \multicolumn{5}{|c|}{$\begin{array}{l}\text { FUNCTION: } \\
\text { Unpack Mk } 18 \text { Package for CD Cask in RBOF }\end{array}$} \\
\hline Scale & & Weight & Score & Final & Rationalization \\
\hline Requirements Maturity & $\mathrm{RM}$ & 0.3 & 8 & 2.4 & $\begin{array}{l}\text { Task has not been performed in recent years and under current } \\
\text { regulatory requirements. (Have not cut in recent years in RBOF } \\
\text { either). }\end{array}$ \\
\hline $\begin{array}{l}\text { Processing \& Storage } \\
\text { Maturity: }\end{array}$ & $\overline{P M}$ & 0.9 & 9 & $\overline{8.1}$ & $\begin{array}{l}\text { Task has not been performed in recent years and under current } \\
\text { regulatory requirements. (Have not cut in recent years in RBOF } \\
\text { either. }\end{array}$ \\
\hline $\begin{array}{l}\text { Transportation Processs } \\
\text { Maturity }\end{array}$ & TPMP & & 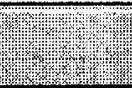 & & A \\
\hline $\begin{array}{l}\text { Process \& Storage } \\
\text { Hardware } \\
\text { Equipment Maturity }\end{array}$ & $E Q$ & 0.9 & 9 & 8.1 & Many fuels have been unpacked but not in an isolation chamber. \\
\hline $\begin{array}{l}\text { Transportation Hardware } \\
\text { Equipment Maturity }\end{array}$ & TEQ & 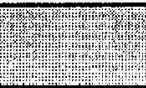 & & & 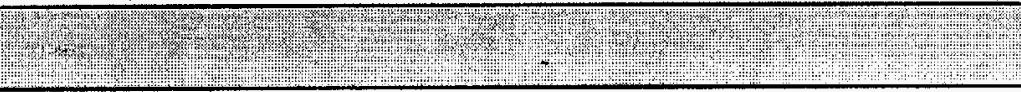 \\
\hline $\begin{array}{l}\text { Facility Equipment } \\
\text { Readiness }\end{array}$ & FAC & 0.9 & 3 & 2.7 & Major modifications required to design/test isolation chamber. \\
\hline $\begin{array}{l}\text { Operational Safety } \\
\text { Readiness }\end{array}$ & SAFT & 0.3 & 10 & 3.0 & $\begin{array}{l}\text { ORR required. Risk of fuel failure and resulting contamination. } \\
\text { Very little containment in RBOF once out of water. }\end{array}$ \\
\hline Personal Resource Status & PER & 0.1 & 3 & .1 & Several people will require major training. \\
\hline Schedule Maturity & $\mathrm{SCH}$ & 0.3 & 4 & 1.2 & $\begin{array}{l}\text { Basic equipment exists but new design for modification is very } \\
\text { conceptual. Schedule inputs are from experienced personnel } \\
\text { based on experience with cutting in current RBOF configuration } \\
\text { (not in isolation chamber). }\end{array}$ \\
\hline NEPA Readiness & NEPA & 0.9 & 8 & 7.2 & Nuclear Spent Fuel EIS has not been released for public hearing \\
\hline $\begin{array}{l}\text { End State System } \\
\text { Interface Requirements }\end{array}$ & ESI & 0.9 & 8 & 7.2 & $\begin{array}{l}\text { Design requirements for interface with basin are known. New } \\
\text { concept. Needs complete analysis }\end{array}$ \\
\hline
\end{tabular}


Appendix M

9.13.7.2. Cut Mk 18 for Shipment or ORNL

\begin{tabular}{|c|c|c|c|c|c|}
\hline $\begin{array}{l}\text { Mk } 18 \text { Disposition - } \\
\text { Base Alternative }\end{array}$ & \multicolumn{5}{|c|}{$\begin{array}{l}\text { FUNCTION: } \\
\text { Cut Mk } 18 \text { in RBOF for Shipment to ORNL. }\end{array}$} \\
\hline Scale & & Weight & Score & Final & Rationalization \\
\hline Requirements Maturity & $\mathrm{RM}$ & 0.3 & 8 & 2.4 & $\begin{array}{l}\text { Task has not been performed in recent years and under current } \\
\text { regulatory requirements. (Have not cut in recent years in RBOF either }\end{array}$ \\
\hline $\begin{array}{l}\text { Processing \& Storage } \\
\text { Maturity: }\end{array}$ & PM & 0.9 & 9 & 8.1 & $\begin{array}{l}\text { Fuels have been irradiated for }>10 \text { years and material may be brittle } \\
\text { so task will be performed in an isolation chamber. }\end{array}$ \\
\hline $\begin{array}{l}\text { Transportation Process } \\
\text { Maturity }\end{array}$ & TPM & & & & \\
\hline $\begin{array}{l}\text { Process \& Storage } \\
\text { Hardware } \\
\text { Equipment Maturity }\end{array}$ & $E Q$ & 0.9 & 9 & 8.1 & $\begin{array}{l}\text { Mk } 18 \text { s have been cropped in past but not analogous to what exists } \\
\text { now. Existing equipment may not now cut without potential } \\
\text { contamination releases. (Use of isolation chamber) }\end{array}$ \\
\hline $\begin{array}{l}\text { Transportation Hardware } \\
\text { Equipment Maturity }=\end{array}$ & TEQ & & ans & 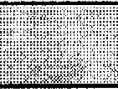 & 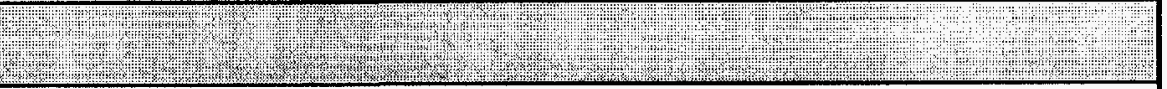 \\
\hline $\begin{array}{l}\text { Facility Equipment } \\
\text { Readiness }\end{array}$ & FAC & 0.9 & 7. & 6.3 & $\begin{array}{l}\text { Modifications for under water cutting and contamination control } \\
\text { would be required. ()Use isolation chamber) }\end{array}$ \\
\hline $\begin{array}{l}\text { Operational Safety } \\
\text { Readiness }\end{array}$ & SAFT & 0.3 & 10 & 3.0 & $\begin{array}{l}\text { ORR required. Risk of fuel failure and resulting contamination. Very } \\
\text { little containment in RBOF once out of-water. }\end{array}$ \\
\hline Personal Resource Status & PER & 0.1 & 3 & .3 & Several people will require major training. \\
\hline Schedule Maturity & $\mathrm{SCH}$ & 0.3 & 4 & 1.2 & $\begin{array}{l}\text { Basic equipment exists but new design for modification is very } \\
\text { conceptual. Schedule inputs are from experienced personnel based } \\
\text { on experience with cutting in current RBOF configuration (not in } \\
\text { isolation chamber). }\end{array}$ \\
\hline NEPA Readiness & NEPA & 0.9 & 8 & 7.2 & Nuclear Spent Fuel EIS has not been released for public hearing \\
\hline $\begin{array}{l}\text { End State System } \\
\text { Interface Requirements }\end{array}$ & ESI & 0.9 & 8 & 7.2 & $\begin{array}{l}\text { Design requirements for interface with basin are known. New } \\
\text { concept. Needs complete analysis }\end{array}$ \\
\hline
\end{tabular}

\subsubsection{Package for Shipment (Refer to Section 9.13.1.4 and 9.13.2.4)}

9.13.7.4. Ship to ORNL (Refer to Section 9.13.1.5)

9.13.7.5. Store at ORNL (Refer to Section 9.13.1.6) 


\section{Appendix M}

\subsection{8. "Mark 18s" - Alternative \#1}

Transfer to F-Canyon and Dissolve for Vitrification, Ship to ORNL

9.13.8.1. Ship to F-Canyon

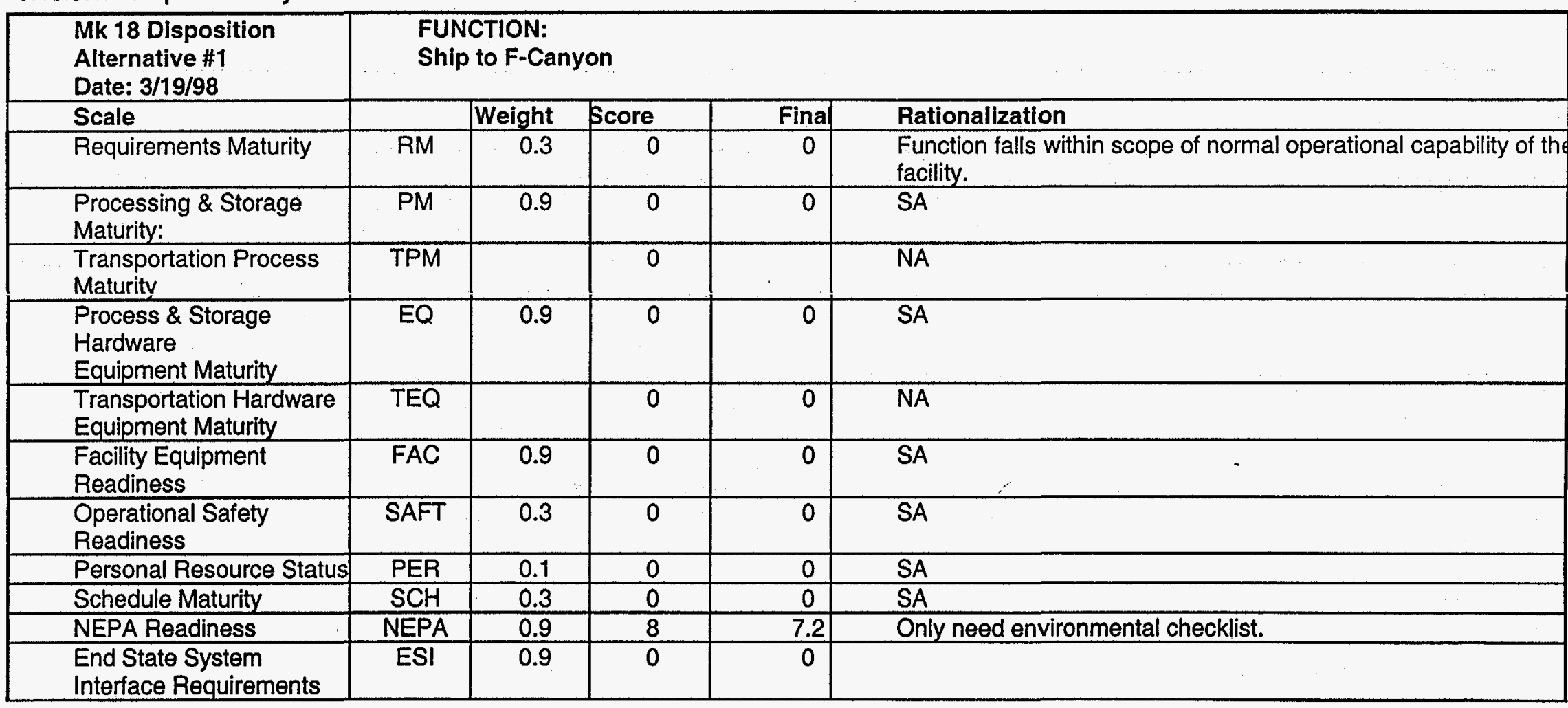


Appendix M

9.13.8.2. Dissolve Mk 18's

\begin{tabular}{|c|c|c|c|c|c|}
\hline $\begin{array}{l}\text { Mk } 18 \text { Disposition - } \\
\text { Alternative \#1. }\end{array}$ & $\begin{array}{l}\text { FUNCTIO } \\
\text { Dissolve }\end{array}$ & k 18s & & & \\
\hline Scale & & Weight & Score & Final & Rationalization \\
\hline Requirements Maturity & $\mathrm{RM}$ & 0.3 & 4 & 1.2 & Flow sheets for a previous Californium project exists. \\
\hline $\begin{array}{l}\text { Processing \& Storage } \\
\text { Maturity: }\end{array}$ & PM & 0.9 & 6 & 5.4 & $\begin{array}{l}\text { Have processed Mk } 18 \mathrm{~s} \text { previously during MPPF californium } \\
\text { program. }\end{array}$ \\
\hline $\begin{array}{l}\text { Transportation Process } \\
\text { Maturity }\end{array}$ & TPM & & & & \\
\hline $\begin{array}{l}\text { Process \& Storage } \\
\text { Hardware } \\
\text { Equipment Maturity }\end{array}$ & $E Q$ & 0.9 & 6 & $\overline{5.4}$ & $\begin{array}{l}\text { This is not an experimental process. Dissolution in canyon has } \\
\text { been done }\end{array}$ \\
\hline $\begin{array}{l}\text { Transportatlon Hardware } \\
\text { Equipment Maturity }\end{array}$ & 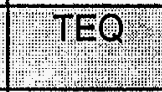 & & 3 & & Sals \\
\hline $\begin{array}{l}\text { Facility Equipment } \\
\text { Readiness }\end{array}$ & FAC & 0.9 & 5 & 4.5 & $\begin{array}{l}\text { Canyon has a dissolver and jumpers. Some modifications will } \\
\text { have to be made to the existing equipment. }\end{array}$ \\
\hline $\begin{array}{l}\text { Operational Safety } \\
\text { Readiness }\end{array}$ & SAFT & 0.3 & 8 & 2.4 & ORR probably required \\
\hline Personal Resource Status & PER & 0.1 & 0 & 0 & Dissolution process is normal operation for canyon personnel \\
\hline Schedule Maturity & $\mathrm{SCH}$ & 0.3 & 2 & .6 & $\begin{array}{l}\text { Preliminary design exists. Inputs is from experienced personne } \\
\text { based on analogous experience }\end{array}$ \\
\hline NEPA Readiness & NEPA & 0.9 & 8 & 7.20 & Will include in site-specific EIS. \\
\hline $\begin{array}{l}\text { End State System } \\
\text { Interface Requirements }\end{array}$ & $\overline{E S I}$ & 0.9 & 4 & 3.6 & $\begin{array}{l}\text { Similar process design exist. There is some minor volatility in } \\
\text { minor requirements. }\end{array}$ \\
\hline
\end{tabular}

\subsubsection{Store $\mathrm{Am} / \mathrm{Cm}$ Solution}

9.13.8.4. Make Glass (Refer to Section 9.13.1.1)

9.13.8.5. Package for Shipment (Refer to Section9.13.1.4 and 9.13.2.4)

9.13.8.6. Store at ORNL (Refer to Section 9.13.1.6) 
Appendix M

9.13.9. Slugs/Other - Base Alternative

Package Slugs in RBOF and Ship to ORNL

9.13.9.1. Package Slugs for Shipment In RBOF (Refer to Section 9.13.1.4)

9.13.9.2. Ship to ORNL (Refer to Section 9.13.1.5)

9.13.9.3. Store at ORNL (Refer to Section 9.13.1.6) 


\section{Appendix $\mathbf{N}$}

\subsection{Appendix N: Mark 18s Background}

This appendix seeks to set forth the current physical dimensions of the Mark 18 targets. It is intended to be an overview and is written such that no classified information will be included. Refer to DPSOP 134, Revision 6, July 1982 , pages $2204-5$ for more detail. A figure at the end of this appendix is provided. For more detailed drawings, consult the following:

ST-MDX5-7797 Rev. 13, Mark 18 fuel dimensions

ST-MDX5-8256, Mark 18 Assemblies

ST-MDX4-8142, Outer Target Tube Machining

ST-MDX5-8141, Outer Target Housing Weldment

The original length of the Mark 18 targets was 252 in. Both ends have been cropped (past history). The current length of the targets is now approx. 92 in. long, with a 4.22 in. diameter. Of that length, the length of the core ("active element") is in the approximate center and is $\sim 48$ in. $+/-6$ in.

Each Mark 18 target is housed in RBOF in an aluminum can, larger than the target, capped with a crimped fit lid with a j-tube for expelling gas. Each canned target is housed in another aluminum can with dimensions of 5.56 in. diameter by 14 feet length. This outermost can is also capped with a crimped fit lid and j-tube. RBOF/ Fuel Handling Engineering advises to ship this entire package to FCanyon or ORNL without opening either of the two cans. The primary issue being the expected condition of the Mk18s, resulting in a high potential for contamination release if the Mk18s are repackaged in RBOF.

Historical records show that when the inner targets were first shipped to RBOF, it took approximately 20 trips with about 5 targets transported at a time using the existing on-site cask. However the original insert in the cask may not be able to accommodate the extra width due to the double aluminum cans surrounding the target, i.e. 4.22 in. vs 5.56 in. dia. The length is not a problem for the insert.

References for the fuel cask inserts that were used originally to ship the Mark 18 assemblies from Reactors to RBOF are unavailable. Based on knowledge of site shipping experts pertaining to other cask insert sizes that are designed to carry bare fuel, it has been surmised that the originally designed Mark 18 cask insert would not dimensionally accept canned Mark 18 targets. Original drawings of the inserts could confirm this.

Cask inserts are also referred to as fuel bundle frames. Approximately one year ago, Spent Fuel Storage Division designed a new fuel bundle frame for use with Research Reactor Fuel (RRF). The working width of this cask insert is 5.75 inches. Since the canned Mark 18 OD is 5.563 inches, the RRF insert may work for handling/transporting the canned Mark 18 targets. A calculation has been done, T-CLC-L-00015, in which a more detailed description of the RRF cask insert can be found. This insert is designed to transport three rows of RRF.

Use of the RRF insert for shipping the canned Mark 18 targets will have to be evaluated. Typically this includes the type of calculation that was performed for the RRF fuel along with a criticality analysis. Presently there is an On-site Safety Assessment being performed for the 70-Ton site transfer cask(s). This assessment will identify the types of contents to be shipped in the cask. The most recent information from on-site shipping experts is that the canned Mark 18s will fit the 70-Ton cask RRF insert. 


\section{Appendix $\mathbf{N}$}

Figure of Cianned Mark 18 Target

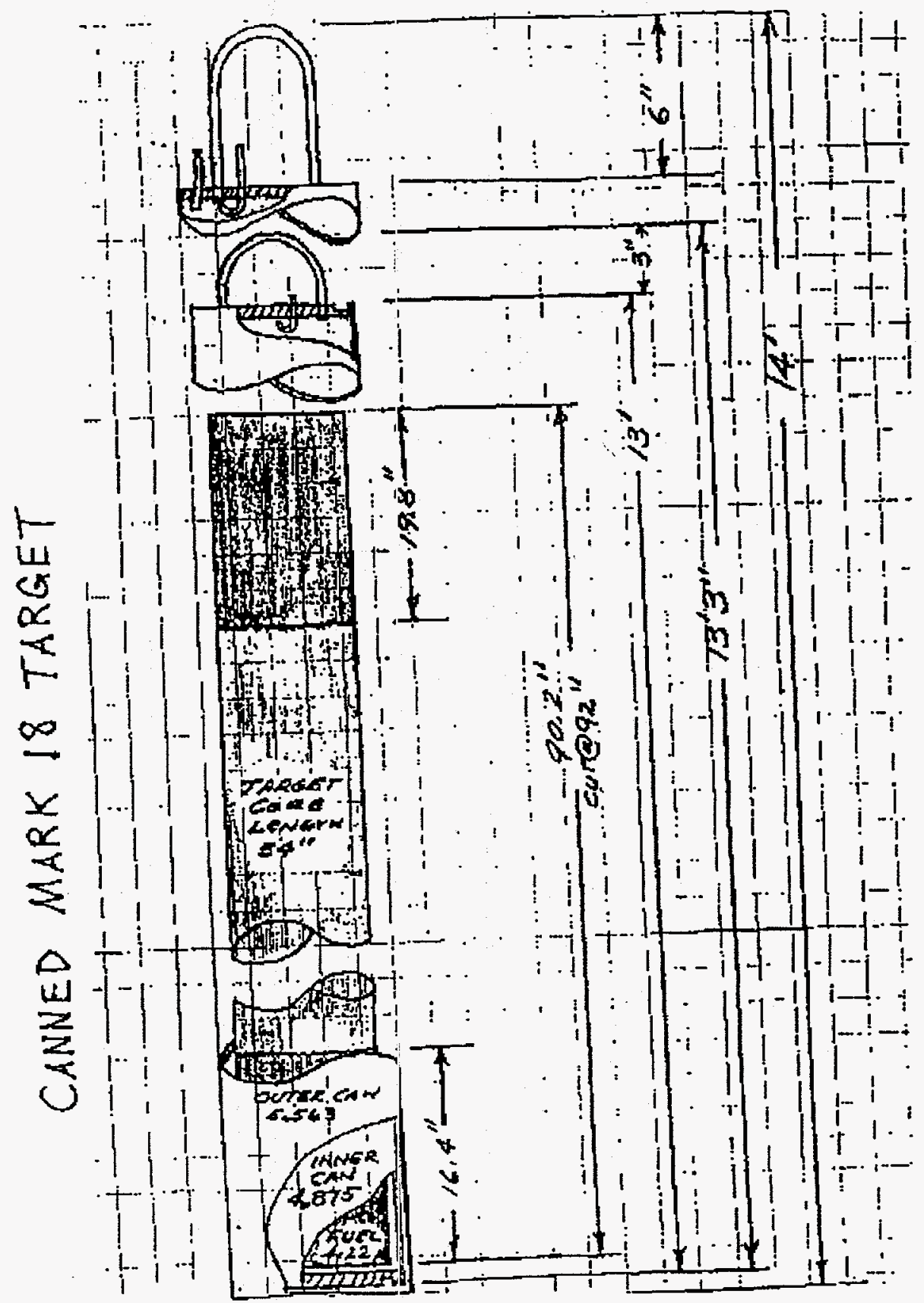




\section{Appendix $\mathbf{N}$}

Figure of Canned Mark 18 Target

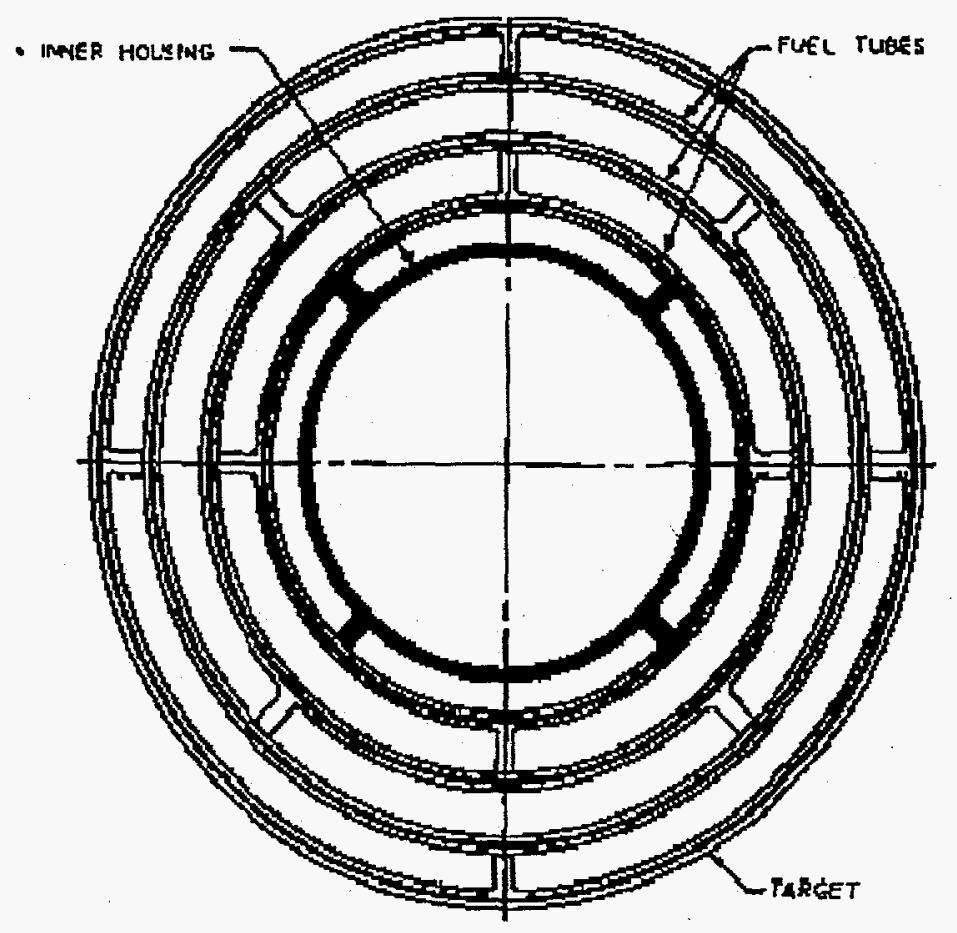

MARK IAA 